Portland State University

PDXScholar

Spring 1-1-2012

\title{
Late Pleistocene and Holocene Aged Glacial and Climatic Reconstructions in the Goat Rocks Wilderness, Washington, United States
}

Joshua Andrews Heard Portland State University

Follow this and additional works at: https://pdxscholar.library.pdx.edu/open_access_etds

Part of the Climate Commons, Geomorphology Commons, and the Glaciology Commons Let us know how access to this document benefits you.

\section{Recommended Citation}

Heard, Joshua Andrews, "Late Pleistocene and Holocene Aged Glacial and Climatic Reconstructions in the Goat Rocks Wilderness, Washington, United States" (2012). Dissertations and Theses. Paper 557. https://doi.org/10.15760/etd.557

This Thesis is brought to you for free and open access. It has been accepted for inclusion in Dissertations and Theses by an authorized administrator of PDXScholar. Please contact us if we can make this document more accessible: pdxscholar@pdx.edu. 
Late Pleistocene and Holocene Aged Glacial and Climate Reconstructions in the

Goat Rocks Wilderness, Washington, United States

by

Joshua Andrews Heard

Master of Science

in Geology

Thesis Committee:

Andrew G. Fountain, Chair

Scott F. Burns

James E. O'Connor

Portland State University

(C)2012 


\section{Abstract}

Eight glaciers, covering an area of $1.63 \mathrm{~km}^{2}$, reside on the northern and northeastern slopes of the Goat Rocks tallest peaks in the Cascades of central Washington. At least three glacial stands occurred downstream from these glaciers. Closest to modern glacier termini are Little Ice Age (LIA) moraines that were deposited between 1870 and 1899 AD, according to the lichenometric analysis. They are characterized by sharp, minimally eroded crests, little to no soil cover, and minimal vegetation cover. Glacier reconstructions indicate that LIA glaciers covered $8.29 \mathrm{~km}^{2}, 76 \%$ more area than modern ice coverage. The average LIA equilibrium line altitude (ELA) of $1995 \pm 70 \mathrm{~m}$ is $\sim 150 \mathrm{~m}$ below the average modern ELA of $2149 \pm 76 \mathrm{~m}$. To satisfy climate conditions at the LIA ELA, the winter snow accumulation must have been 8 to $43 \mathrm{~cm}$ greater and mean summer temperatures 0.2 to $1.3{ }^{\circ} \mathrm{C}$ cooler than they are now. Late Pleistocene to early Holocene (LPEH) aged moraines are located between 100 and $400 \mathrm{~m}$ below the LIA deposits. They have degraded moraine crests, few surface boulders, and considerable vegetation and soil cover. Volcanic ashes indicate LPEH moraines were deposited before $1480 \mathrm{AD}$ while morphometric data suggest deposition during the late Pleistocene or early Holocene. The average LPEH ELA of $1904 \pm 110 \mathrm{~m}$ is $\sim 240 \mathrm{~m}$ and $\sim 90 \mathrm{~m}$ below the modern and LIA ELAs, respectively. The climate change necessary to maintain a glacier with an ELA at that elevation for LPEH conditions requires the winter accumulation to increase by 47 to $48 \mathrm{~cm}$ weq and the mean summer temperature to cool by 1.4 to $1.5^{\circ} \mathrm{C}$. Last glacial maximum (LGM) moraines are located more than $30 \mathrm{~km}$ downstream from 
modern glacial termini. They are characterized by hummocky topography, rounded moraine crests, complete vegetation cover, and well developed soil cover. Moraine morphometry, soil characteristics, and distance from modern glacial termini indicate that deposition occurred at least $15 \mathrm{ka}$ BP during an expansive cooling event, the last being the LGM. The LGM ELA of $1230 \mathrm{~m}$ is $~ 920 \mathrm{~m}$ below the modern ELA. The climate change necessary to maintain a glacier with an ELA at that elevation for LGM conditions requires the mean summer temperature to cool by $5.6^{\circ} \mathrm{C}$ with no change in precipitation. 


\section{Dedication}

This thesis is dedicated to two women who have taught and continue to teach me how to give to the world through my heart: my fiancée and my mother.

Thank you for all your love. 


\section{Acknowledgments}

I would like to thank my advisor, Andrew G. Fountain, for making this thesis opportunity possible, for his continued effort and outpouring of knowledge submitted from a broad range of latitudes, and for his guidance and patience that helped make my graduate school experience very enjoyable. I am grateful to Scott Burns for taking time in the field to educate me on alpine soil characteristics and for his ubiquitous enthusiasm and positivity in every discussion I've ever had with him. I thank Jim O'Connor for sharing his understanding and insight of alpine environments and his commitment in helping me through the thesis process.

Thanks to Doug Clark for guiding me through possible scenarios of paleo-lake creation and for kindly making available, twice, his magnetic susceptibility meter for lake sediment analysis. I would like to thank Rick McClure for permitting access to alpine soils, for the many, I suspect and hope, enjoyable hours he put into locating and clearing soil sites, and for his wonderful company in the field.

A special thanks to the Mazama's for funding radiocarbon and AMS analysis of woody debris and ash deposits. This project would not have been as complete without those analyses.

Thanks to Kevin Parine, Matt Brunengo, Bert Schene, Anna O’Coyne, Craig Heard, Trent Smith, Adam Cockrill, Melissa McBride, Katie Heard, Tim Schene, and Kent Stalling for field assistance. Your sacrifices included but were not limited to forfeiting hats and valuable equipment to the field and lots of blood to the mosquitoes, 
sitting in a tent for four straight days while it rained and snowed, putting up with, what appeared to be, very painful boot blisters, hiking through the night, off-trail, while towing a $75 \mathrm{lb}$. core of sediment, and, in one day, digging through $2 \mathrm{~m}$ of till with an old trench shovel... not an easy feat. I hope that the moments of relaxing in lupine meadows, munching on wild huckleberry pancakes, viewing Mt. Adams, Mt. St. Helens, and Mt. Rainier from one vista, watching mountain goats jump crevasses and listening to elk bugle made it all worth it. 


\section{Table of Contents}

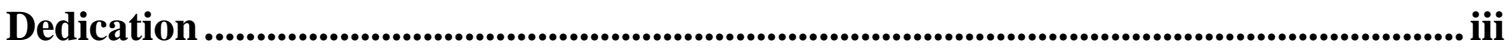

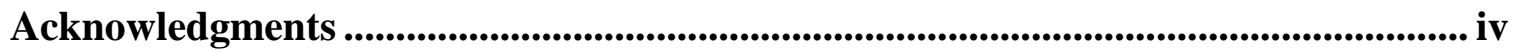

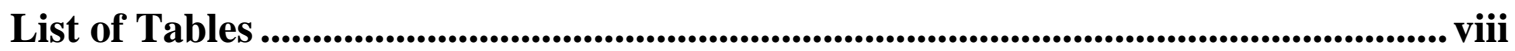

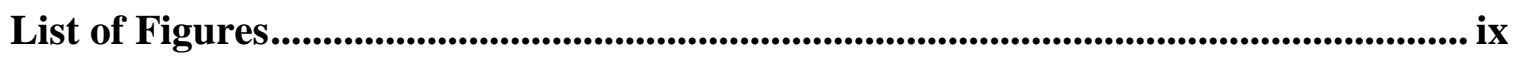

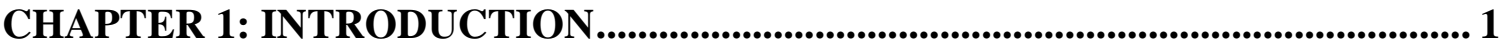

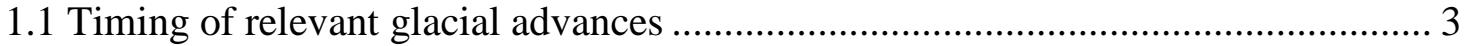

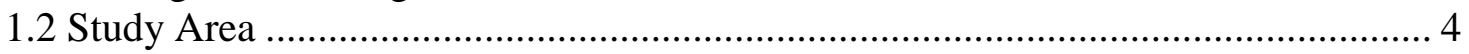

CHAPTER 2: METHODOLOGY ...............................................................................8 8

2.1 Methods for mapping of pro-glacial deposits and modern glaciers ....................... 8

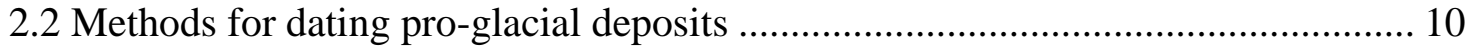

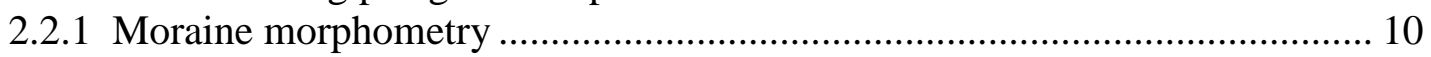

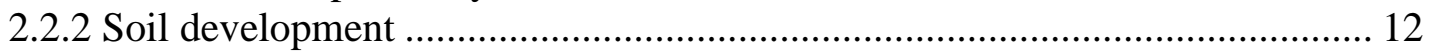

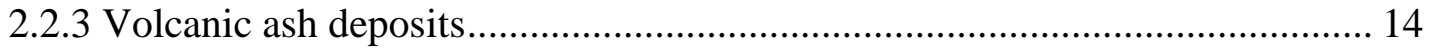

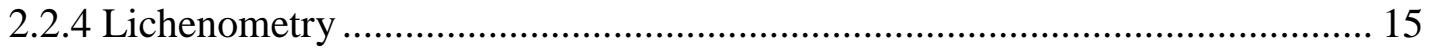

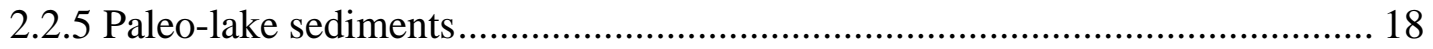

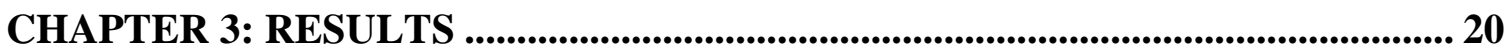

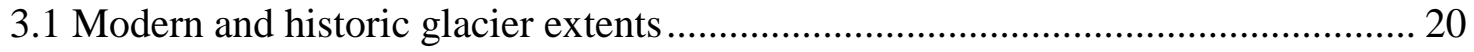

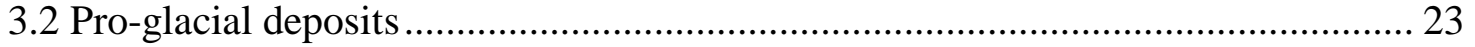

3.2.1 Packwood Glacier Basin ......................................................................... 23

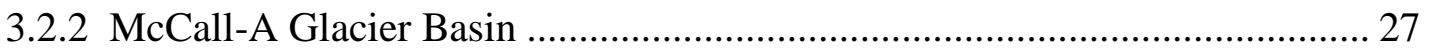

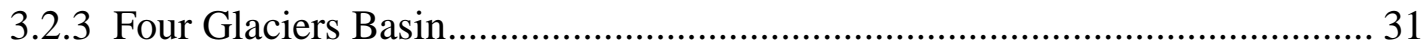

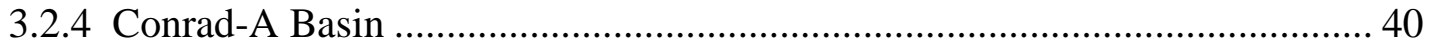

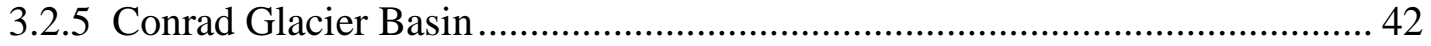

3.2.6 Snowgrass Flats and Goat Lake Basins .................................................... 44

3.2.7 Walupt Lake Basin................................................................................ 49

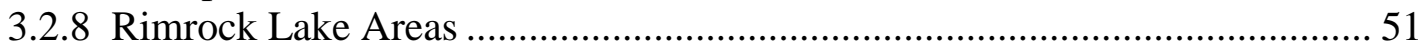

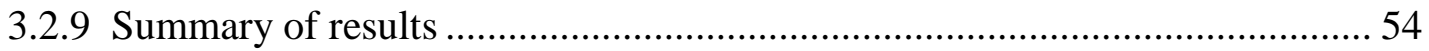

CHAPTER 5: PALEOCLIMATE RECONSTRUCTION.......................................... 60

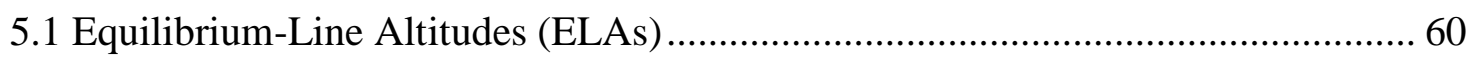

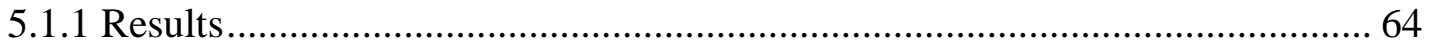

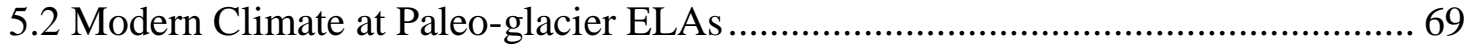

CHAPTER 6: DISCUSSION \& CONCLUSIONS .................................................. 78

6.1 Goat Rocks glacial deposits and their age correlations to other western North American glacial deposits 78 


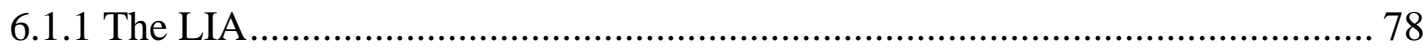

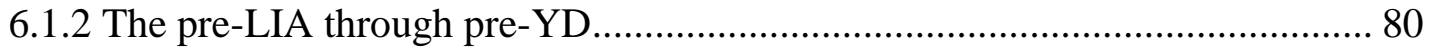

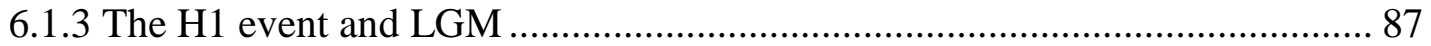

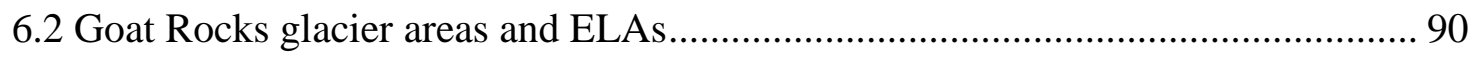

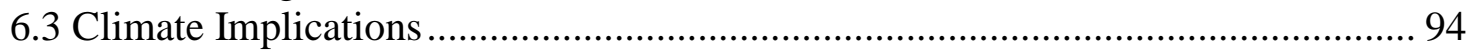

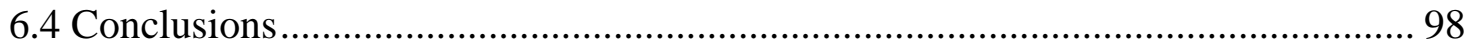

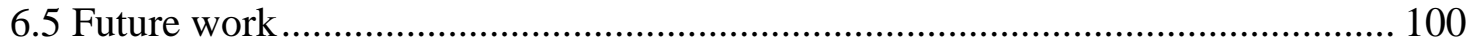

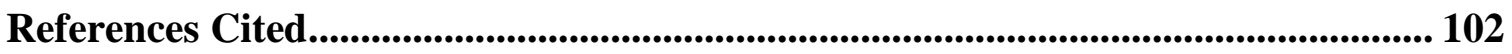

Appendix A: Soil Pit Stratigraphic Cross Sections and Descriptions ...................... 112

Appendix B: Moraine measurements................................................................... 136

Appendix C: Lichen measurements and ages ............................................................ 137

Appendix D: Volcanic ash deposit results ....................................................... 142 


\section{List of Tables}

Table 1: Glacier areas $\left(\mathrm{km}^{2}\right)$ for the Goat Rocks in 2009 and in $1955 . \Delta \%$ and $\Delta \%$ b are the approximate area percentage each glacier lost from 1955 to 2009 and from the LIA to 2009, respectively

Table 2: Depth (cm) to weathered horizons in all soil pits in the Goat Rocks. Soil pits are arranged from the shallowest weathered depth to deepest and correlated ash layers and radiocarbon ages and relative stratigraphic positions. Notice that depths to $B$ horizon generally increase with age correlation.

Table 3: Equilibrium line altitudes (ELAs) for all modern and pre-existing glaciers in the Goat Rocks Wilderness, listed in order of calculations (shown for Meade glacier) from the AAR method (Meier and Post, 1962), the AA method (Kurowski, 1891), the BR method under the Benn \& Gimmel (1997) program (BR $\left.{ }^{(B \& G)}\right)$ and the BR method under the Osmaston (2005) program $\left(B R^{(0)}\right)$ for each glacier. The McCieton Glacier is a large LGM glacier that includes the coalescence of all McCall Glaciers, the Glissade Glacier and the Tieton Glacier. ELAs are in meters. > LIA and $>$ LGM represent glaciers that are no longer present. The $1^{\text {st }}, 2^{\text {nd }}, 3^{\text {rd }}$ and last ELA estimates for each glacier are calculated 65

Table 4: Modern (1971-2000) mean summer (June-August) temperatures and highest monthly mean snow accumulation (April or May) at SNOTEL sites near the Goat Rocks Wilderness, WA. Cm weq is $\mathrm{cm}$ of water equivalent. Lat, Long is the latitude and longitude in degrees and minutes. 70

Table 5: Interpolated and extrapolated modern climate data for modern and past ELAs, using BR method calculation techniques by Osmaston (2005), in the Goat Rocks Wilderness.............................................................................................. 75

Table 6: Climate adjustments using Table 5 and Leonard (1989) required to match paleo-ELA climate conditions to modern ELA or modern climate envelope climate conditions. 


\section{List of Figures}

Figure 1: Goat Rocks Wilderness and surrounding area in southwestern Washington State. The white areas with blue borders are modern glaciers. Red triangles are prominent peaks and the yellow rectangle depicts the main area of focus and is expanded as Figure 2. .....................................................................................5 5

Figure 2: The Goat Rocks Wilderness highest peaks and glaciers. Much of the research and data collection for this project was collected in this area...................... 7

Figure 3: Aerial photo of the Tieton Glacier (front right) and Conrad Glacier (back left). The peaks that the glaciers rest below are the highest peaks in the Goat Rocks. Photo by John Scurlock, 2007 (www.pbase.com/nolock)

Figure 4: Moraine boulder with a community of $R$. geographicum lichens. 17

Figure 5: Graph of Rhizocarpon geographicum lichen measurements and their respective ages. The linear regression equation used to determine ages of lichen in the Goat Rocks (adapted from O’Neal and Schoenenberger, 2003).

Figure 6: Conrad Glacier in the Goat Rocks Wilderness, WA. Note the glacier recession from Conrad Lake between the two photographs. 1958 photo from Molenaar, 1985. 2007 photo from John Scurlock.

Figure 7: Glacial moraines downstream from modern and extinct glaciers near the Goat Rocks highest peaks. Photo base is NAIP imagery. See Figure 1 for larger scale location.

Figure 8: Glacial moraines and drift downstream $\sim 25 \mathrm{~km}$ northeast of source area. Photo base is NAIP imagery. See Figure 1 for larger scale location. 25

Figure 9: Aerial image of the Packwood Glacier Basin. Downstream from Packwood Glacier rest moraines crests and associated deposits (including their ages) as well as the locations of lichen measurement collection. Photo base is NAIP imagery. See Figure 2 for larger scale location..................................................................... 26

Figure 10: Aerial image of the McCall-A Glacier basin. Glacially deposited left lateral and terminal moraines and their associated deposits (including their ages; the age of M1 is LPEH), the locations of lichen measurement collection and soil pit sites rest downstream from McCall Glacier-A. Notice the two terminal moraines located directly downstream from McCall Glacier-A. Terminal moraines are sparse in the Goat Rocks Wilderness. Photo base is NAIP imagery. See Figure 2 for larger scale location 28 
Figure 11: Terminal LIA moraine (M2) located downstream from the McCall-A Glacier. Note the lack of vegetation and soil cover suggesting recent deposition..... 29

Figure 12: Terminal LPEH moraine (M1) located downstream from the McCall-A Glacier. This moraine typifies physical characteristics of an early Holocene or YD deposit. Notice the degraded and rounded crest, abundant vegetation cover and lack of surface boulders indicating soil accumulation. 30

Figure 13: Aerial image of the Four Glaciers basin. Glacially deposited left lateral, right lateral, terminal, and medial moraines and their associated deposits (including their ages) as well as the locations of lichen measurement collection rest downstream from McCall Glacier-B, McCall Glacier-C, Glissade Glacier and Tieton Glacier. Notice that McCall Glacier-C, Glissade Glacier, and Tieton Glacier are currently seaparate glaciers; however, appear to have coalesced as one glacier during maximum LIA extension. Photo base is NAIP imagery. See Figure 2 for larger scale location. 32

Figure 14: The medial moraine (M7) evolves to a right lateral moraine and separates McCall-B Glacier from McCall-C Glacier. Notice the lack of vegetation, sharp crest, and minimal soil accumulation. This suggests the moraine is relatively young. 33

Figure 15: Large right lateral moraine (M4) downstream from the Tieton Glacier. This moraine represents the typical physical characteristics of a Little Ice Age moraine. Notice the lack of vegetation, sharp crest, and very little soil accumulation.

Figure 16: Atop the Tieton Glacier's right lateral moraine (M4) looking downstream northward. Note the distinct crestal sharpness. 35

Figure 17: Geomorphic map of paleo-lake in McCall Area. Located downstream from McCall Glacier-B, McCall Glacier-C, Glissade Glacier, and Tieton Glacier (Inset) is the site of SP1 containing paleo-lake laminated sediments. The elevation of the potential lake shoreline is $\sim 1390 \mathrm{~m}$. 37

Figure 18: Outcrop of paleo-lake sediments located downstream from the Tieton Glacier on the north fork of the Tieton River. For scale, the outcrop is $\sim 3 \mathrm{~m}$ in height. The inset in the upper corner shows the beginning stages of extracting the lake sediments at the bottom of SP1. The inset in the lower corner shows a close-up of the laminated sediments. 38

Figure 19: Aerial image of the Conrad and Meade Glacier Basins. Shown are glacially deposited left lateral and terminal moraines and their associated deposits 
(including their ages), the locations of lichen measurement collection and soil pit sites resting downstream from Conrad and Meade glaciers............................................. 42

Figure 20: Aerial photo of valley downstream from the Conrad Glacier. Shown are four soil pits downstream from a unstable face of andesitic brecciated tuff (circled in red). Photo base is NAIP imagery.

Figure 21: Aerial photo of the Snowgrass Flats Area (the south side of the Goat Rocks highest peaks). Notice the lack of mapped glacial deposits. The south side of the Goat Rocks contained very few LIA glaciers and appears to have last experienced glacial activity prior to the Late Neoglacial. Photo base is NAIP imagery. See Figure 2 for larger scale location. 46

Figure 22: Soil profile of SP9 located on the south side of the Goat Rocks highest peaks in the Snowgrass Flats area. SP9 was dug on a meadow and contains numerous ash deposits. The red rectangles are volcanic ashes and the yellow rectangle is the ash deposit from the MSH P eruption. 47

Figure 23: Aerial photo of the Goat Lake cirque, its terminal moraine and the soil pit and lichen measurements sites in the Snowgrass Flats Area. This is the only LIAtype moraine discovered on the southern side of the Goat Rocks highest peaks. The cirque lake is highly protected from direct sun exposure. Photo base is NAIP imagery. See Figure 2 for larger scale location. 49

Figure 24: Aerial photo of the Walupt Lake drainage south of the Snowgrass Flats area. Shown is the location of soil pit 10 (SP10). SP10 was dug in a meadow lying down slope from a few glacial erratics but no moraines. Photo base is NAIP imagery. See Figure 2 for larger scale location. 50

Figure 25: Aerial image of moraines near the Rimrock Dam in the Rimrock Lake Area. These moraines are over $25 \mathrm{~km}$ downstream from the Goat Rocks glaciers. The lake elevation is $892 \mathrm{~m}$ asl. 52

Figure 26: Right lateral hummocky moraine deposited near the Rimrock Lake Dam. This moraine represents the typical physical characteristics of a LGM-type deposit. The inset in the upper left corner is of a highly weathered and exfoliating boulder (1 m dia.) located just out of the figure. The red dashed line is the hummocky moraine crest. 53

Figure 27: Aerial map of glacial drift near the inlet of Rimrock Lake. Shown is soil pit 11 (SP11) which was dug in a meadow surrounded by drift. 54

Figure 28: Proximal and distal slope angles for 14 moraines in and near the Goat Rocks Wilderness Area, shown in squares and circles, respectively. The largest 
cluster of proximal slope points, circled above, represent Little Ice Age (LIA) deposits, the middle cluster represent late Pleistocene (LPEH) deposits, and the lowest cluster represent Last Glacial Maximum (LGM) and pre-LGM deposits. Refer to Table B, Appendix B for key of y-axis. ............................................................... 56

Figure 29: Aerial image with all of the Goat Rocks modern and paleo- glaciers. Historic glacier coverage is from 1955, digitized from USGS topographic maps..... 59

Figure 30: The AA method variables depicted on the Tieton Glacier. The black numbers are contour line elevations and the black letters represent each contour belt (at a $100 \mathrm{~m}$ contour interval) for the Tieton Glacier. The trial ELA is meant to be raised or lowered until Equation 4 produces a zero sum. 62

Figure 31: Modern glacier perimeters used to calculate ELAs in the Goat Rocks... 66

Figure 32: LIA glacier perimeters used to calculate ELAs (also shown) in the Goat Rocks.

Figure 33: LPEH glacier perimeters used to calculate ELAs (also shown) in the Goat Rocks. While other glaciers certainly existed during this time they have been left off this figure because no evidence was located to recreate them. 67

Figure 34: LGM glacier perimeter used to calculate the LGM ELA (also shown) in the Goat Rocks. While other glaciers certainly existed during this time they have been left off this figure because no evidence was located to recreate them. The source area is where the McCall-B, McCall-C, Glissade, and Tieton Glacier's currently reside. 68

Figure 35: SNOTEL sites near the Goat Rocks Wilderness. The red and blue circles represent SNOTEL sites that were used for highest monthly mean snow accumulation and mean summer temperatures, respectively........................................ 71

Figure 36: Linear regression analysis lines for summer temperature versus elevation at seven SNOTEL sites (top graph) and for snow accumulation ( $\mathrm{cm}$ of water equivalent) versus elevation for four SNOTEL sites (bottom graph) in close proximity to the Goat Rocks Wilderness. 72

Figure 37: Modern average winter snow accumulation versus summer (JuneAugust) average temperatures for modern ELAs at a worldwide distribution of 32 glaciers (Leonard, 1989) and at the modern ELAs for Goat Rocks glaciers (using BR method calculation techniques by Osmaston 2005). The black circles and represent the 32 worldwide glaciers. Weq is snow water equivalent or the amount of water within a snowpack. 74 
Figure 38: Estimated climate conditions at modern and past ELAs and the minimum and maximum temperature depressions and winter accumulation increases required to shift paleo-ELAs into modern climate conditions. The black circles in each graph represent the 32 world wide glaciers used to create the modern climate envelope.

Figure 39: Research locations concerning temporal and spatial aspects of alpine glacier systems in the western United States and southwestern Canada. The yellow square represents the study area for this thesis. Glacial advance/standstill dates are in italic. * represent ${ }^{14} \mathrm{C}$ ages. All other dates are years before present as determined by calibration, $3^{\mathrm{Cl}}$ ages, $1^{\mathrm{Be}}$ ages, or $3^{\mathrm{He}}$ ages.......................................................... 81

Figure 40: Western United States glacial advances in relation to distinct cooling events (blue shadings)

Figure 41: Equilibrium line altitude elevations versus latitude for glacial regions in the western United States. The black line represents a general decline of ELA elevation with increasing latitude. This is a factor of decreased summer temperatures with increasing latitude.

Figure 42: Oxygen (delta ${ }^{18} \mathrm{O}$ ), temperature, and incoming solar radiation (insolation) in relation to distinct cooling events (blue shadings). Oxygen data were collected at Dome $\mathrm{C}$ in Antarctica, temperature data were collected in central Greenland, and insolation data represent the Earth at $60^{\circ} \mathrm{N}$ (adapted from Lorius et al., 1979; Alley, 2000; and Berger and Loutre, 1991, respectively) 96 


\section{CHAPTER 1: INTRODUCTION}

Temperate mountain glaciers and their deposits are important sources for paleoenvironmental information (Porter and Swanson, 2008). Responding sensitively to climate variations, mountain glaciers can be indicators of both long and short-term climate fluctuations (Thackray et al., 2004). Reconstructions of pre-existing mountain glaciers have been used to determine temperature and precipitation conditions associated with periods of glacial advances (Refsnider et al., 2008). Historically, the fluctuations of alpine glaciers throughout western North America were suggested to be broadly synchronous with North America's continental ice sheets and with each other, induced by extreme cooling events, such as the Last Glacial Maximum (LGM) (Thackray, 2008). While this may be the case, mounting data suggest that alpine glacier systems also fluctuate in response to more regional scale factors (Thackray, 2008; Refsnider et al., 2008).

Air temperature and precipitation are the most dominant variables, among many, that influence alpine glacier size (Leonard, 1989; Porter, 1977). Further, air temperature and precipitation patterns are uniquely influenced by regional orographic effects (Licciardi et al., 2004), such as the cases of cold easterly winds flowing through the Columbia River Gorge and the "rainshadow" effect on the western slopes of the Cascade Mountains, respectively. While cooling and warming events of the global scale generate evidence for coeval glacier advances and recessions, as seen in North America (Phillips et al., 1996; Owen et al., 2003; Licciardi et al., 2004; Porter and Swanson, 2008; Thackray, 2001; Licciardi and Pierce, 2008; Chadwick et al., 1997; Phillips et al., 1997; 
Gosse et al., 1995), regional orographic effects influence glaciers locally (Thackray, 2008). To explore the relationships between regional orography, orographically influenced climate, and glacial fluctuations, we need to expand our understanding of glacier fluctuations over broader areas where little research has been conducted, such as the Goat Rocks Wilderness. By studying glacier fluctuations in the Goat Rocks, it may be possible to deduce whether glaciers there synchronously or asynchronously fluctuated with neighboring glaciers in Washington and Oregon. This, in turn, may provide insight to future studies as to how much orographic settings influence glacial fluctuations.

Little glacial mapping has been completed in the Goat Rocks Wilderness. Schasse (1987) mapped glacial boulders and till as glacial terrain but investigated no further. Heine (1997) mapped and dated possible moraine deposits in the Goat Rocks, thought to be Younger Dryas in age but provided no absolute age estimates. Bidlake (2007) conducted a study on $20^{\text {th }}$ century ice loss of four of the glaciers in the Goat Rocks Wilderness but did not investigate glacial deposits. The lack of paleo-climatic data in the Goat Rocks confirms the region to be an important area of study.

The objectives of this thesis are to map glacial deposits in the Goat Rocks Wilderness, to date material collected on those deposits, to correlate those dates with glacial activity elsewhere in the western United States, and to improve the record of alpine glacier change during the late Pleistocene and Holocene. 


\subsection{Timing of relevant glacial advances}

All uncalibrated radiocarbon ages examined from other reports and discussed herein were calibrated with the calibration program CALIB Rev 6.0.1 (in conjunction with Stuiver and Reimer, 1993) using the 95\% confidence limits of the calibrated ages. Radiocarbon ages are presented in this document as both calibrated years before 1950 $\mathrm{AD}$ (i.e. $13.5 \pm 0.2 \mathrm{ka} \mathrm{BP}$ ) and radiocarbon years before present (i.e. $11.7 \pm 0.1{ }^{14} \mathrm{C} \mathrm{ka}$ BP). Terrestrial cosmogenic radionuclide (TCRN) dates (i.e. ${ }^{10} \mathrm{Be}$ and ${ }^{36} \mathrm{Cl}$ ) are presented as cosmogenic years before present (i.e. $14.4{ }^{10} \mathrm{Be}$ ka BP). Although the TCRN method is continuously being calibrated by using sites with reliable independent age control and known simple exposure history (Gosse and Phillips, 2001), I assume that reported ages have minimal uncertainties and are equivalent to calibrated years before present.

For my study, the Late Pleistocene concerns the period of time between $\sim 25 \mathrm{ka}$ $\mathrm{BP}$ and the end of the Pleistocene epoch ( 11.7 ka BP), including advances that transpired during the global Last Glacial Maximum (LGM), the Heinrich 1 event ( $17 \mathrm{ka}$ BP), and Younger Dryas (YD) Stade ( 12 ka BP) (Heinrich, 1998; Heine, 1997). The Holocene subsumes relevant advances that occurred from its beginning ( $11.7 \mathrm{ka}$ BP) to the present, including glacial resurgences just after the YD, during the $8.2 \mathrm{ka} \mathrm{BP}$ cooling event and through the Neoglacial period. The period from AD 1450 to the late AD 1800's is termed the Little Ice Age (LIA). 


\subsection{Study Area}

The Goat Rocks Wilderness includes $427.4 \mathrm{~km}^{2}\left(165 \mathrm{mi}^{2}\right)$ of rugged terrain along the crest of the Cascade Range in southwestern Washington (46 $29^{\prime} 52^{\prime \prime} \mathrm{N}, 121^{\circ} 25^{\prime} 51^{\prime \prime}$ W) (Figure 1). This landscape contains peaks that rise higher than 2450 meters above sea level (m asl) and valley floors resting below $900 \mathrm{~m}$ asl. The Goat Rocks have been carved by glacial and fluvial activity since the early Pleistocene. At least seven large, radially distributed glaciers once deeply carved U-shaped valleys where the Cispus River, North and South Forks of the Tieton River, the Klickitat River, the Clear Fork "Cowlitz" River, Conrad Creek and the Upper Lake Creek now flow (Ellingson, 1968). Currently, eight alpine glaciers (Packwood, McCall-A, McCall-B, McCall-C, Glissade, Tieton, Conrad, and Meade) and multiple perennial snowfields form a patchy ice cover on the north and northeast slopes of the highest peaks (Figure 2). The Goat Rocks contain glacially eroded valleys and cirques as well as moraines that offer settings for the collection of proxy climate indicators. 


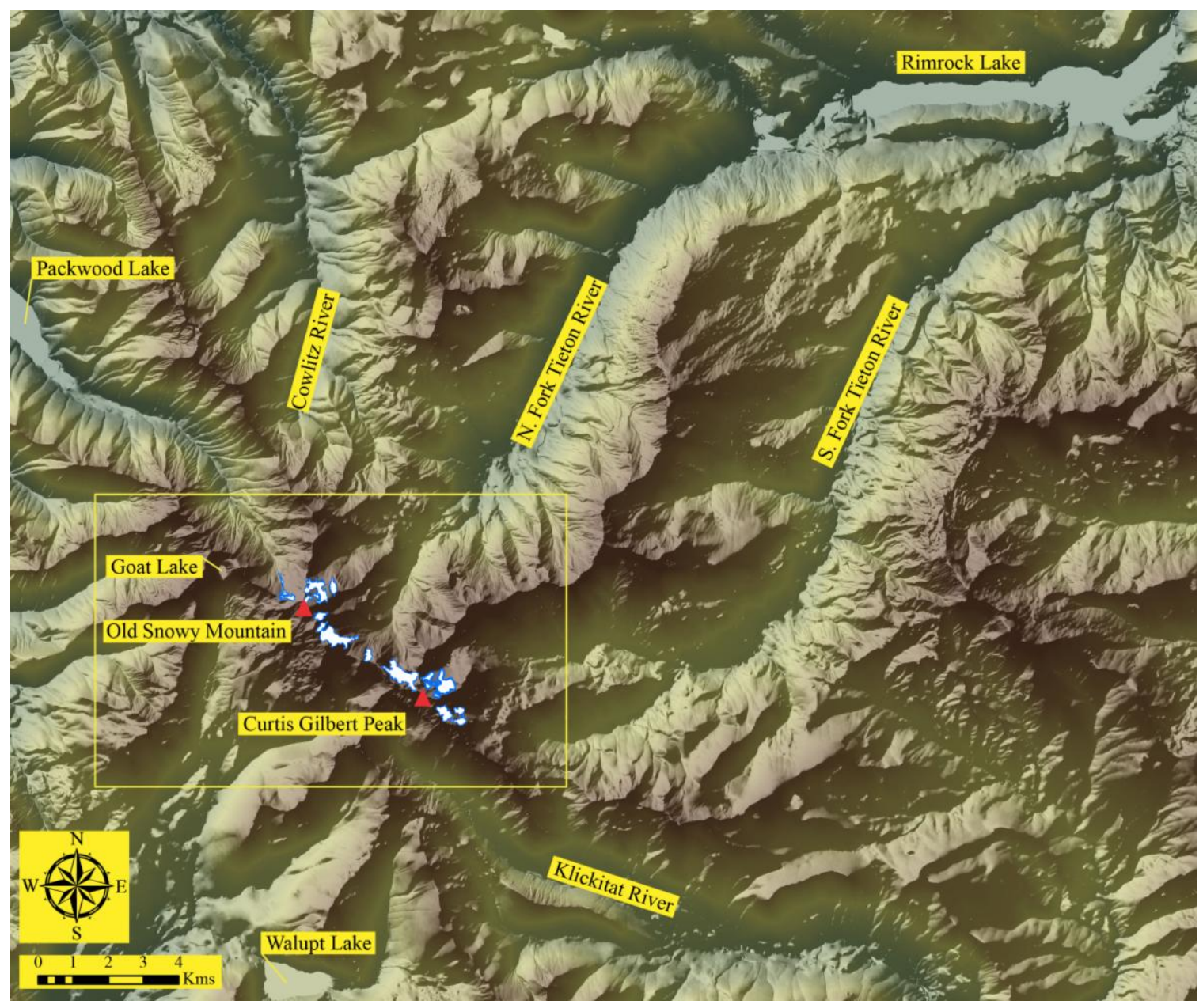

Figure 1: Goat Rocks Wilderness and surrounding area in southwestern Washington State. The white areas with blue borders are modern glaciers. Red triangles are prominent peaks and the yellow rectangle depicts the main area of focus and is expanded as Figure 2.

The highest peaks of the Goat Rocks are remnants of the now-extinct $3650 \mathrm{~m}$ Goat Rocks composite volcano (Ellingson, 1968). Zircon fission-track ages for rhyolitic tuff, flows, and breccias indicate that volcanism began $~ 3.2$ million years ago $(\mathrm{Ma})$ (Clayton, 1983). Volcanic activity continued into the Pleistocene until the most recent lava flows of 0.5 Ma (Schasse, 1987; Wood and Kienle, 1990). During the volcanic period high- $\mathrm{K}_{2} \mathrm{O}$ pyroxene and hornblende andesites were erupted from vents along the highest ridges in the study area. At $\sim 1.0 \mathrm{Ma}$, the Tieton Andesite erupted and flowed 
more than $80 \mathrm{~km}$ eastward down the Tieton River drainage, making it the longest known andesitic flow on Earth (Wood and Kienle, 1990).

In the core of the Goat Rocks, between Tieton, Curtis Gilbert, and Johnson peaks, the andesites are interbedded with volcanic breccias and lahars (Swanson and Clayton, 1983). The andesitic lava flows of the Goat Rocks volcano were deposited on top of the Oligocene-aged Ohanapecosh Formation, which consists of andesitic and dacitic volcaniclastic rocks, altered basaltic-andesitic lithic breccia, tuff, and tuff breccia, volcaniclastic siltstone, sandstone, and conglomerate, and less common rhyolitic flows and airfall and ash-flow tuffs (Fiske et al., 1963; Swanson and Clayton, 1983). This formation is more than $2300 \mathrm{~m}$ thick and is commonly found as steep valley walls in the Goat Rocks Wilderness. Pre-Tertiary basement rocks of the Russell Ranch Formation rest unconformably underneath the Ohanapecosh Formation. They include strongly deformed graywacke and argillite, with less common pillow basalts, chert and thin tuffaceous beds (Swanson and Clayton, 1983). Well preserved carbonaceous detritus and radiolarians indicate that the Russell Ranch Formation was formed during the Cretaceous and Jurassic (Schasse, 1987). Because the rocks of the Russell Ranch Formation are extremely altered and highly erodible, it is unlikely that any glacial deposits still superimpose them. 


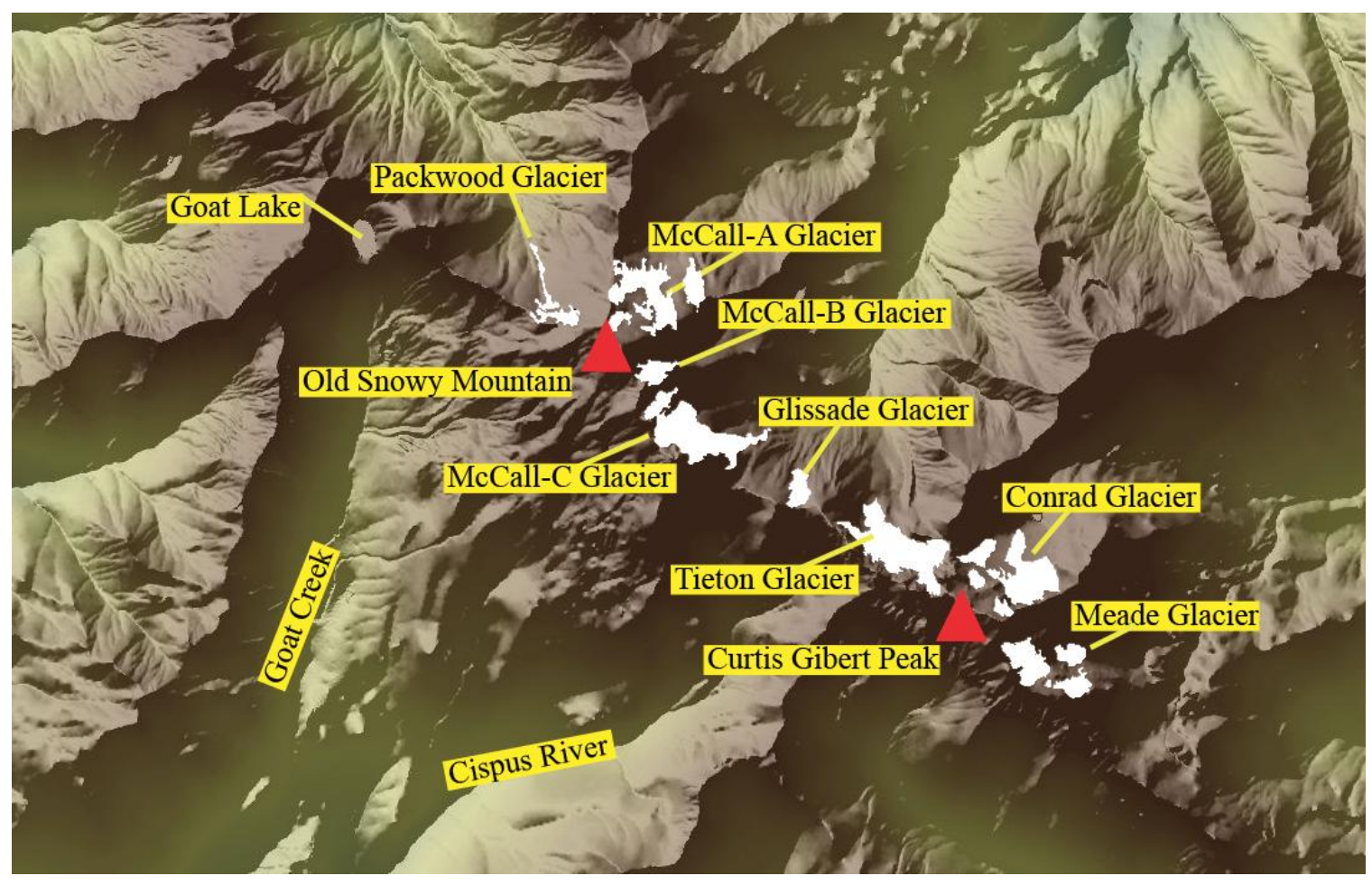

Figure 2: The Goat Rocks Wilderness highest peaks and glaciers. Much of the research and data collection for this project was collected in this area. 


\section{CHAPTER 2: METHODOLOGY}

\subsection{Methods for mapping of pro-glacial deposits and modern glaciers}

To prepare for field work, aerial photographs were examined in the spring of 2009 to identify the likely locations for ancient pro-glacial deposits and modern glacial extents. This involved analyzing digital orthoquadrangle imagery (DOQs), digital elevation models (DEMs), digital raster graphics (DRGs), and oblique aerial photos acquired in 2007 by John Scurlock (Figure 3). Following remote imagery examination, the Goat Rocks Wilderness was investigated extensively by foot during the field seasons of 2009 and 2010.

Field maps of pro-glacial deposits and present glaciers were compiled on 1:24,000 scale USGS topographic maps during the summers of 2009 and 2010. Mapped deposits include moraines and distinct areas of glacial boulders that were emplaced as glaciers ablated. Moraines and glacially deposited boulders were identified by noting shape, lithology, and their location to modern glaciers. Field maps of modern glacier extents were also compiled on 1:24,000 scale USGS topographic maps during the summer of 2009, updating 1955 limits shown on topographic maps. To map the current glacier extents the perimeters were walked and located using a global positioning system (GPS). Glacial ice and crevasses were used to distinguish glaciers from snowfields. Glacier edges deemed too dangerous to reach and locate with a GPS were digitized using DOQ's (National Agriculture Imagery Program images from 2009) and aerial images (John Scurlock photos from 2007) in ESRI's ArcGIS. Once field maps were completed they 
were transferred to a digital form using ArcGIS. The digital maps were used to digitize modern and paleo-glacier extents and areas. Field mapping and digitization methods presented area uncertainties (error) using techniques discussed in Sitts et al (2010). Glacier areas, the main variable needed to determine equilibrium line altitudes, were then calculated at $100 \mathrm{~m}$ intervals (500 m interval for the recreated LGM glacier). This final method is discussed further in Chapter 4.

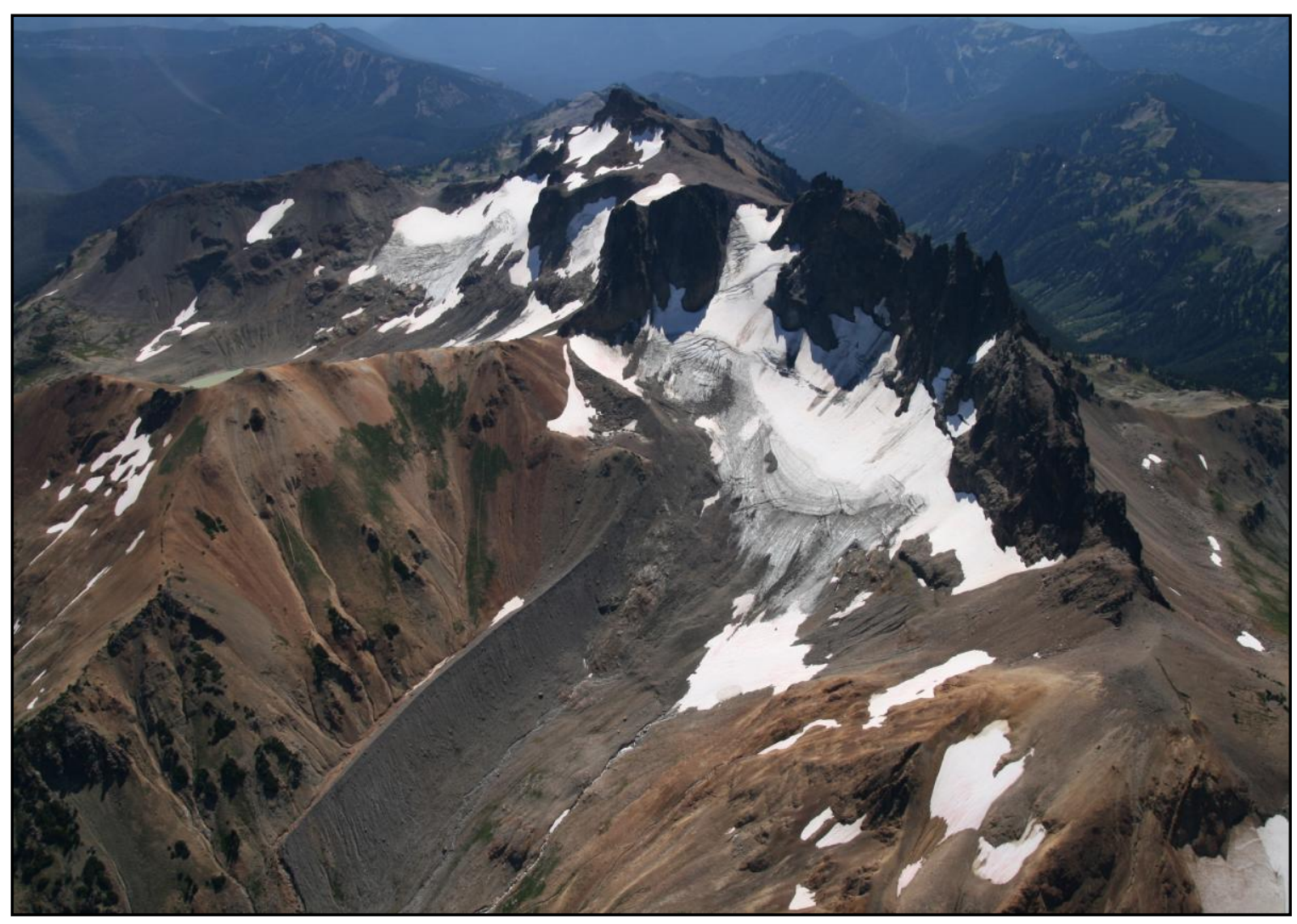

Figure 3: Aerial photo of the Tieton Glacier (front right) and Conrad Glacier (back left). The peaks that the glaciers rest below are the highest peaks in the Goat Rocks. Photo by John Scurlock, 2007 (www.pbase.com/nolock). 


\subsection{Methods for dating pro-glacial deposits}

Because no single method of relative age dating is adequate to differentiate all glacial deposits (Birkeland, 1973), numerous methods were used to distinguish the deposits in the Goat Rocks Wilderness. The majority of the mapped deposits were dated using relative dating techniques including soil properties, moraine morphometry, and volcanic ash deposits, while radiocarbon dating and lichenometrric techniques were applied to acquire accurate absolute dates. Soil properties and moraine morphometry are two characteristics that vary with age owing to post-depositional modifications and are based on the assumption that weathering rates are temporally constrained (Birkeland et al., 1979).

\subsubsection{Moraine morphometry}

Topographic morphometry can be used to differentiate the age of glacial deposits (Ruhe, 1950). Moraines are typically deposited with sharp, narrow crests and steep slopes. These sharp crests degrade over time (Birkeland et al., 1979; Kaufman and Calkin, 1988). I used this principle in the Goat Rocks to help determine relative ages for moraines. Of the more than 40 moraines located in the Wilderness Area, most were situated close to modern glaciers and only 13 of the moraines, based on moraine crest continuity, appeared suitable for morphometric measurements.

Moraine morphometry was based on four variables: moraine crest width, moraine height, and proximal and distal slope angles. Measured with a GPS, the moraine crest 
width is the distance between two points perpendicular to the crest axis and one tenth the moraine height from the top (adapted from Colman and Pierce, 1986). The moraine height was determined by using a GPS and subtracting the moraines base elevation from the moraines crest elevation. GPS elevation error was estimated to $\pm 1 \mathrm{~m}$ and considered consistent over short distances of measurement. Both slopes were measured at three locations along the moraines midsection parallel to the crest axis using a straight edge and a brunton compass (adapted from Colman and Pierce, 1986). Because data from this relative dating method are limited in the northwestern United States, data from the Alpine Creek type moraines (the youngest in the Alturas Lake Valley glacial sequence of the Sawtooth Mountains, Idaho) as well as the Pilgrim Cove and Timber Ridge type moraines (the youngest and oldest sets found at Payette Lake near McCall, Idaho, respectively) were used to assist in relative age determination for Goat Rocks moraines. Soil development, vegetation cover, and stratigraphic position, included for relative age dating, were also considered for morphometric comparison. Further, the emplacement of glacial moraines, which often results in obliteration of any older moraines that were deposited by less extensive glacial advances (Gibbons et al., 1984), was also used to help determine relative moraine ages in relation to each other.

Moraine morphometry methods assume that all moraines are deposited in similar form (Kaufman and Calkin, 1988). However, variables such as underlying terrain or the presence of ice within the moraine can control the primary morphology. I have assumed, for moraines residing near the current glacier termini, the underlying bedrock is uniform because andesitic rocks dominate the highest elevations in the Goat Rocks. I cannot make 
this assumption for moraines that lie far from Goat Rocks volcanics where underlying bedrock varies from diorites and andesites to sandstones and shales (Campbell and Gusey, 1992). A second assumption is that all moraines are modified by the same weathering variables and at the same rate. Erosion rates can depend on stream incision, slope aspect, vegetation coverage, precipitation rates, and moraine composition and size. However, as difficult as it may be to distinguish moraines using morphometric methods that are separated in age by a few decades or centuries, it is considerably easier to attain relative ages of moraines that are separated in age by millennia.

\subsubsection{Soil development}

Soils play an important role in dating surface deposits in alpine environments throughout the western United States (Mahaney et al., 1981; Birkeland and Burke, 1988; Birkeland et al., 2003). Soil chronosequences in the Front Range of Colorado and the Sierra Nevada of California offer a detailed understanding of alpine soil development (Birkeland et al., 2003; Berry, 1994). In the Cascade Range established chronosequences are available, but are limited to a few regions and by lack of data. A study on Mt. Adams (Mahaney et al., 1981), less than $40 \mathrm{~km}$ south of Goat Rocks, provides detailed chronosequences of alpine soils that have proved useful for my work.

During the summer of 2010, 16 detailed soil descriptions were collected from hand-dug pits located on the crests of three moraines, at the foot slope of one moraine, in pro-glacial meadows, on paleo-lake sediments and on an ancient landslide. Pit locations were chosen where recent erosional processes appeared minimal and where soils were 
expected to provide insight about glacial activity. Foot slope pits were included because they can reflect different soil conditions than those found on moraine crests (Berry, 1994; Birkeland et al., 1991). An example is the process of moraine crest soil erosion followed by redeposition at moraine foot slopes. These pits sometimes provide more mature and detailed chronosequences than do moraine crest pits.

Soil pits were dug to the water table or large boulders. Once dug, the pit walls were cleaned and smoothed for soil observation, measurement, and collection. Field observation and measurements included horizon depth of weathering, structure, clay films, gravel percentage, consistence, and textures following nomenclatures developed by the Department of Agriculture (Soil Survey Division Staff, 1993). Structure was determined by identifying individual aggregates (peds), if any, and describing their type, grade, and size. Clay films were identified with a hand lens and described by recording percentage in media, distinctness, and location (Birkeland, 1999). Gravel percentages were calculated by estimating the volume of material greater than $2 \mathrm{~mm}$ (maximum diameter for sand). The consistence of each soil was established by measuring the adherence of the soil particles to the fingers, the cohesion of soil particles to one another, and the resistance of the soil mass to deformation (Birkeland, 1999). The texture was found by noting grittiness and wet consistence for the fraction of each soil smaller than 2 mm. Field descriptions of wet colors were made by listing the dominant color and any color variation of prominent mottles. After measurements were made $\sim 300$ grams of each soil horizon was collected and taken for further analysis. In the lab, dry colors were determined using Munsell Color Charts and $\mathrm{pH}$ by glass electrode using a 1:1 mixture of 
soil and water. In addition, many of the soil pits contained ash deposits that were also collected and discussed in detail below.

\subsubsection{Volcanic ash deposits}

Volcanic ash deposits of known dates can be used to limit the ages of alpine glacier advances (Beget, 1984). Deposited at irregular intervals throughout the late Pleistocene and Holocene, ash layers have been located in numerous locations on and around Mt. Rainier, Mt. Adams, and Mt. St. Helens (Heine, 1997; Mahaney et al, 1981; Mullineaux, 1996). On Tumac Plateau, a few km's north of the Goat Rocks Wilderness, Clayton (1983) located nine known layers of ash from Mt. Rainier (layers R, L, D, F, and C), Mt. St. Helens (layers Y, P, W, and May $18^{\text {th }}$ 1980), and Mt. Mazama (layer O). Some of these ash deposits, particularly those from Mt. St. Helens and Mt. Mazama, are

present in the Goat Rocks Wilderness. Since in situ and undisturbed ash deposits are younger than the surface upon which they lie, they were used to help determine absolute ages of geomorphic deposits, such as moraine systems, in the Goat Rocks.

Every soil pit that was dug in the Goat Rocks was examined for ash layers. Any identified ash deposits were collected and described by texture and color in the field. The deepest and, hence, the oldest ash deposits were sent to the laboratory of Nick Foit in the geology department at Washington State University for electron microprobe analysis. 


\subsubsection{Lichenometry}

Lichenometric dating was founded on the assumption that many lichen species grow at a quasi-steady rate over spans of centuries to a few millennia (O’Neal and Schoenenberger, 2003). Once a substrate is colonized, the general growth of lichen is radially outward beginning with a rapid growth phase, called the "great growth period", proceeding into a linear phase when the lichen's growth is uniform, and ending with an exponentially slowing growth rate until the lichen eventually dies (O’Neal, 2005; Innes, 1985; Beget, 1994). Because of their reliable growth habits, the maximum diameters of circular or nearly circular lichens can be used to date the time of stabilization of moraine systems (Burbank, 1981). The lichen species Rhizocarpon geographicum is common in the Cascade Range and, because of its radial growth manner, has been widely adopted to date Holocene glacial deposits there (Burbank, 1981; Porter, 1981b; O’Neal and Schoenenberger, 2003).

O’Neal (2005) measured lichen on substrates of known age at Mt. Baker, Mt. Rainier, and Mt. Hood to determine growth rates and construct a growth curve depicting a size vs. age relationship for the Pacific Northwest. Following measurement techniques of Porter (1981b), O’Neal used the "largest lichen" method to create the growth curve. The "largest lichen" method assumes that the largest measured lichen represents the age of the substrate best. However, this method has been criticized because of the uncertainty that the largest lichen may not represent the whole population of lichen on a substrate and that there is a risk of measuring a coalescence of multiple lichen ( $\mathrm{O}^{\prime} \mathrm{Neal}$ and Schoenenberger, 2003). While other methods of lichen measurement may prove more 
accurate, such as the "five largest lichen" technique (averaging the five largest thalli) and the Bayesian technique (Innes, 1985; Jomelli et al., 2007), the Cascadian growth curve is based on the largest lichen method.

Lichens chosen for collection were located on andesitic moraine boulders that appeared to be stationary since deposition and free from excessive vegetation (Figure 4). Using a caliper, the thalli (diameter) of Rhizocarpon geographicum lichen were measured, involving the primary A-axis (widest diameter), the secondary B-axis (perpendicular to A-axis) and averaging the two to attain the mean diameter. Given that lichen grow radially outward and are typically circular in shape, the length of the A and B axes are usually similar. The measurements were then fit, using a linear regression equation, to a growth curve that has been calibrated for the Cascade Range (Figure 5). Calibrated ages are presented as intervals of 95\% confidence. For the age of surfaces between 20 and 145 years old, the $95 \%$ confidence interval provides an error range of \pm 10 years (O'Neal and Schoenenberger, 2003). 


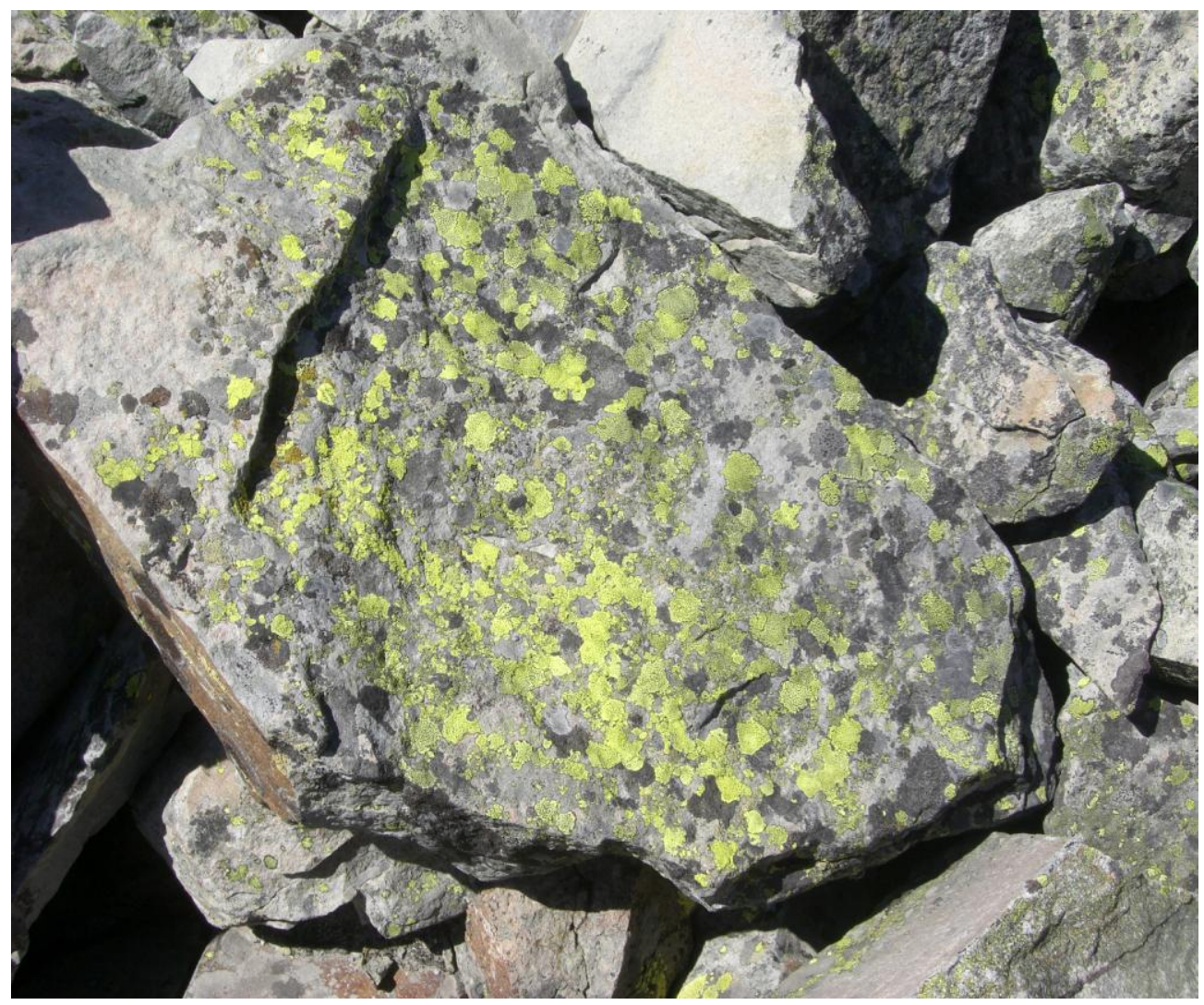

Figure 4: Moraine boulder with a community of $R$. geographicum lichens. 


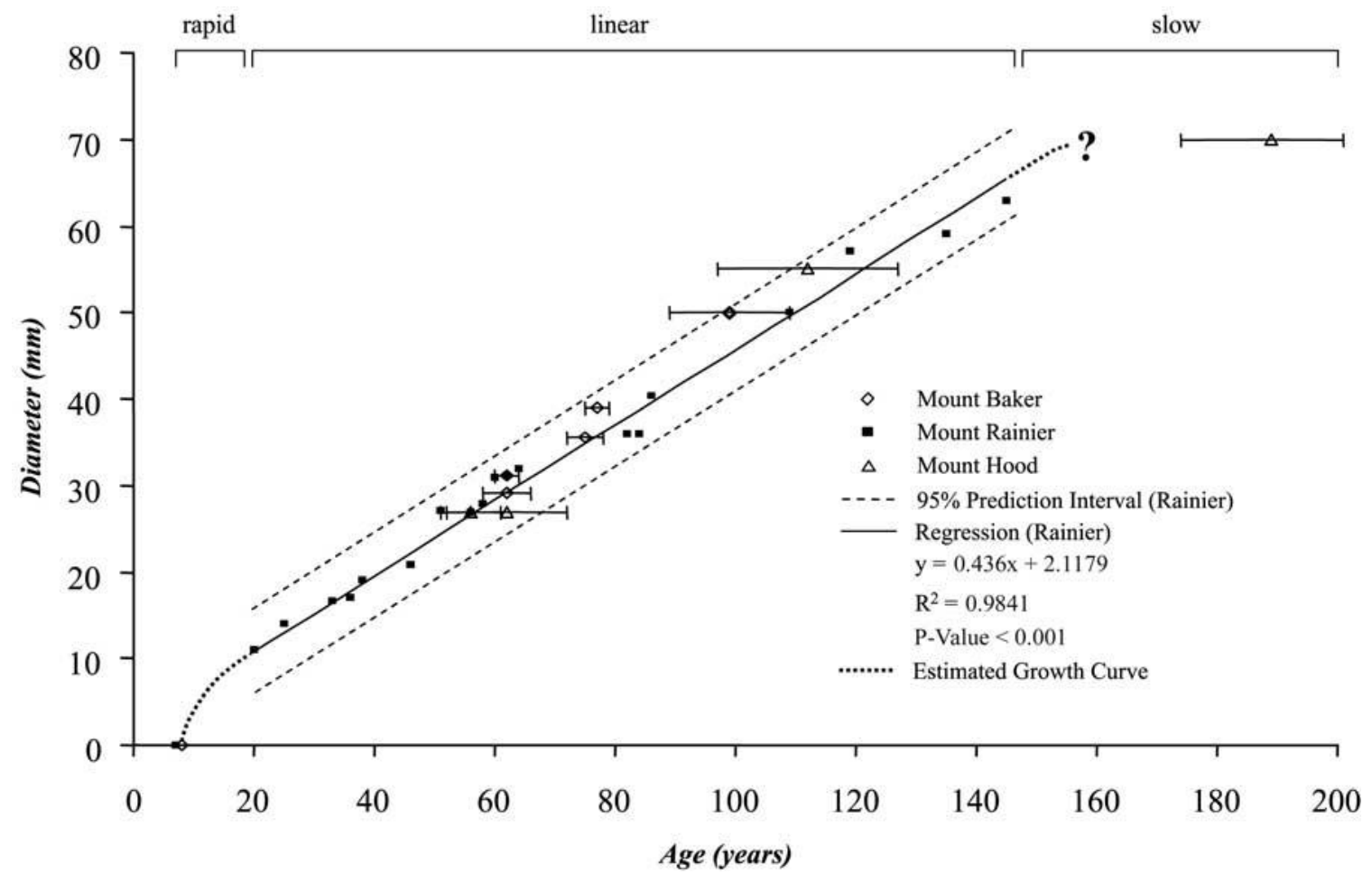

Figure 5: Graph of Rhizocarpon geographicum lichen measurements and their respective ages. The linear regression equation used to determine ages of lichen in the Goat Rocks (adapted from O'Neal and Schoenenberger, 2003).

\subsubsection{Paleo-lake sediments}

In the summer of 2010 paleo-lake sediments were discovered in a circular basin located $\sim 3.5 \mathrm{~km}$ downstream from the Tieton Glacier's terminus. The laminated sediments are exposed in a cutbank of the Tieton River's north fork. They are superimposed by stream sediments and a well developed Inceptisol recorded in Soil Pit 1 (SP1).

The paleo-lake sediments were reached by digging through the $280 \mathrm{~cm}$ thick profile of SP1. Once the surface (most recently deposited) of the ancient lake sediments was encountered, an aluminum core $\sim 120 \mathrm{~cm}$ long and $10 \mathrm{~cm}$ in diameter was pounded 
into the sediment using a rock hammer and a $4 \times 4$ piece of wood. The core tube was extracted using a car jack and rope. In the lab, the aluminum core was split with a radial saw in order to examine the sediments. The sediments magnetic susceptibility was determined using a Bartington Instruments Multisus magnetic susceptibility meter in Dr. Doug Clark's lab at Western Washington University. Organic debris (small twigs) was send into Beta Analytic for radiocarbon analysis (AMS) and calibrated using INTCAL04. 


\section{CHAPTER 3: RESULTS}

\subsection{Modern and historic glacier extents}

The eight glaciers mapped in 2009 reside on the north and northeast slopes of the highest peaks in the Goat Rocks and cover a total area of $1.63 \mathrm{~km}^{2}$ (Table 1). The glacier cover in 1955, based on the date of imagery acquisition on USGS topographic maps, covered a total area of $3.56 \mathrm{~km}^{2}$. Thus, the Goat Rocks glaciers, collectively, have decreased by an average area of $\sim 54.3 \%$ and a weighted average area of $\sim 53.6 \%$ since 1955. The range of percent area change may be caused by glacier size, orientation, rock cover or the accuracy of 1955 USGS coverage (Table 1). These results assume that the 1955 mapping represented glaciers and not seasonal snowfields. This is probably a valid assumption based on photographs taken on October $1^{\text {st }}$ of 1958 , when there was little remaining of the previous winter's snowpack (Molenaar, 1985) (Figure 6).

Table 1: Glacier areas $\left(\mathrm{km}^{2}\right)$ for the Goat Rocks in 2009 and in $1955 . \Delta \%$ and $\Delta \%$ are the approximate area percentage each glacier lost from 1955 to 2009 and from the LIA to 2009, respectively.

\begin{tabular}{|c|c|c|c|c|c|c|c|c|}
\hline Year & Packwood & McCall -A & McCall-B & McCall-C & Glissade & Tieton & Conrad & $\underline{\text { Meade }}$ \\
\hline 2009 & $0.07 \pm .04$ & $0.30 \pm .09$ & $0.06 \pm .02$ & $0.32 \pm .05$ & $0.05 \pm .01$ & $0.33 \pm .05$ & $0.30 \pm .07$ & $0.21 \pm .05$ \\
\hline 1955 & $0.30 \pm .07$ & $0.60 \pm .08$ & $0.19 \pm .03$ & $0.71 \pm .06$ & $0.08 \pm .01$ & $0.45 \pm .06$ & $0.62 \pm .08$ & $0.61 \pm .09$ \\
\hline$\Delta \%^{\mathrm{a}}$ & $75.9 \pm .08$ & $50.6 \pm .12$ & $70.8 \pm .04$ & $55.1 \pm .08$ & $30.6 \pm .01$ & $28.0 \pm .08$ & $52.2 \pm .11$ & $65.8 \pm .10$ \\
\hline $\boldsymbol{L I A}$ & $0.84 \pm .08$ & $1.20 \pm .08$ & $0.66 \pm .07$ & $1.37 \pm .08$ & - & $0.92 \pm .09$ & $0.92 \pm .06$ & $0.74 \pm .07$ \\
\hline$\Delta \%^{\mathrm{b}}$ & $91.5 \pm .09$ & $75.1 \pm .12$ & $91.5 \pm .07$ & $76.7 \pm .09$ & - & $64.3 \pm .10$ & $67.9 \pm .09$ & $71.8 \pm .09$ \\
\hline
\end{tabular}

Based on glacial deposits, the ten Little Ice Age (LIA) glaciers covered a total area of $8.29 \mathrm{~km}^{2}$ at the peak of the LIA. Modern glaciers that created LIA deposits, 
collectively, have decreased by an average area of $\sim 77.0 \%$ and a weighted average area of $\sim 76.3 \%$, since the LIA (Table 1). Area uncertainties arise from glacier positioning, digitizing, photographic interpretation, and GPS error. The main sources of uncertainty were the GPS error $( \pm 15 \mathrm{~m})$ on the modern and LIA glaciers and positional uncertainties $( \pm 12.2 \mathrm{~m})$ for 1955 glacier extent estimates.
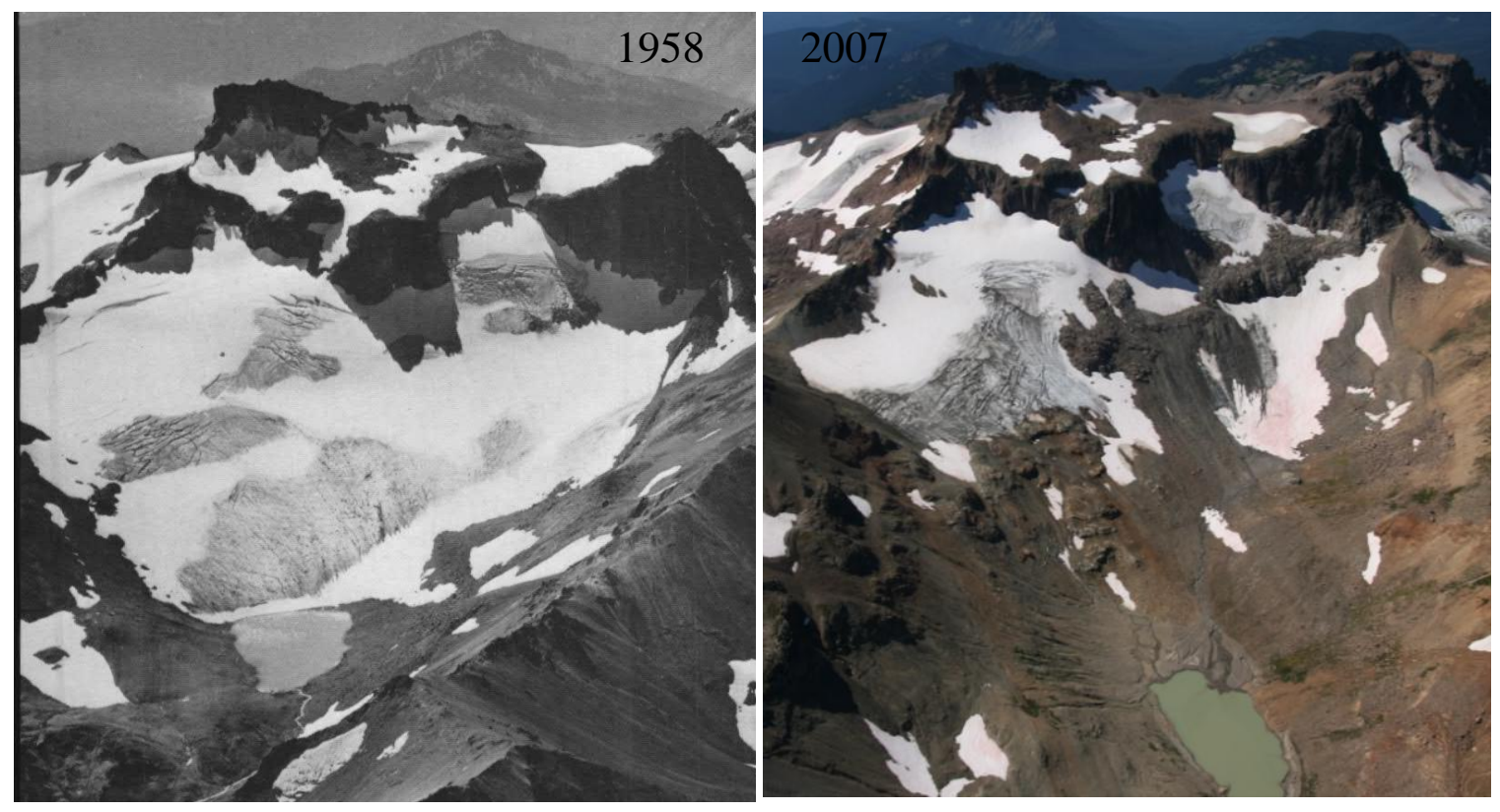

Figure 6: Conrad Glacier in the Goat Rocks Wilderness, WA. Note the glacier recession from Conrad Lake between the two photographs. 1958 photo from Molenaar, 1985. 2007 photo from John Scurlock.

In the Goat Rocks the relationship of soil development to the age of surface deposits has been complicated because of the deposition of volcanic ash from Mt. St. Helens, Mt. Rainier and ancient Mt. Mazama [ 6850 years BP (Crater Lake)]. Light colored and buried volcanic ash deposits can resemble albic E horizons and buried A horizons from certain B horizons (Birkeland, 1999). Nevertheless, key characteristics, 
such as clay content, depth to and thickness of B horizons, and soil chemistry proved valuable in finding relative ages of alpine deposits in the Goat Rocks. Results of soil profile descriptions and stratigraphic cross sections are found in Appendix A.

Morphometric measurements, vegetative coverage percentages, and soil accumulation thicknesses collected on moraines are recorded in Table B (Appendix B). Moraine degradation with time was a primary method for determining the relative age of moraines. As discussed below, proximal slopes angles of moraines proved useful for determining relative moraine ages. Moraine distal slope angles, heights and crest widths were less useful in determining relative ages of moraines in the Goat Rocks. Increases in vegetative coverage and soil thicknesses correlated well with moraine degradation. Obliterative overlap also assisted in setting relative moraine ages, as a moraine set further from its source area must be older than one closer to the same terminus. Lichen measurements are summarized Table C (Appendix C).

B horizons were an important part of determining relative ages of the surface deposits. Measurements such as the depth to and thickness of the B horizon, the base depth of alteration/oxidation and depth of rubification have been utilized to separate deposits into relative age groups (Borgert, 1999; Mahaney et al., 1981; Berry, 1994). Because three soil pits lacked B horizons and the bottoms of another three failed to reach a base depth of oxidation, I applied the depth to weathering (B or Cox horizons) method (Borgert, 1999). Given that volcanic deposits regenerate soil development by acting as newly established parent material, the deepest of the weathered horizons, when volcanic deposits are present, is recorded. 


\subsection{Pro-glacial deposits}

Pro-glacial deposits are located on the north and northeast exposures of the highest peaks and more than $25 \mathrm{~km}$ downstream to the northeast (Figure 7, 8). Deposits of primary focus are found in Packwood Glacier basin, McCall-A Glacier basin, the Four Glaciers basin, Conrad Glacier basin, Conrad basin, Meade Glacier basin, Snowgrass Flats basin, Goat Lake basin, Walupt Lake basin and around Rimrock Lake.

\subsubsection{Packwood Glacier Basin}

The Packwood Glacier Basin contains glacial deposits including four right lateral moraines (M21, M22, M23, and M29) and one hummocky end moraine (M30) (Figure 9). Moraines M22 and M23 are nearest to the Packwood Glacier's terminus and are similar in appearance. Steep proximal slope angles (average of $36.8^{\circ}$ ) and minimal vegetation cover and soil thickness suggest that M22 and M23 are relatively young (Table B, Appendix B). Lichenometric dating of the two right lateral moraines (lichen sites L18 and L19, respectively) suggests that the Packwood Glacier reached a maximum extent during the LIA between 100 and 132 years BP (Table C, Appendix C).

Beyond Packwood Glacier's suggested LIA extent lies a small snowfield; the remains of a glacier (Lower Packwood Glacier) that deposited a large right lateral moraine (M21) (Figure 9). Lichen data (L12) suggest that M21 was deposited between 129 and 149 years BP, during the LIA (Table C, Appendix C). The elevation of lichen (L12) collected on M21 fits those elevations of lichen collected for the Cascadian growth curve well. 


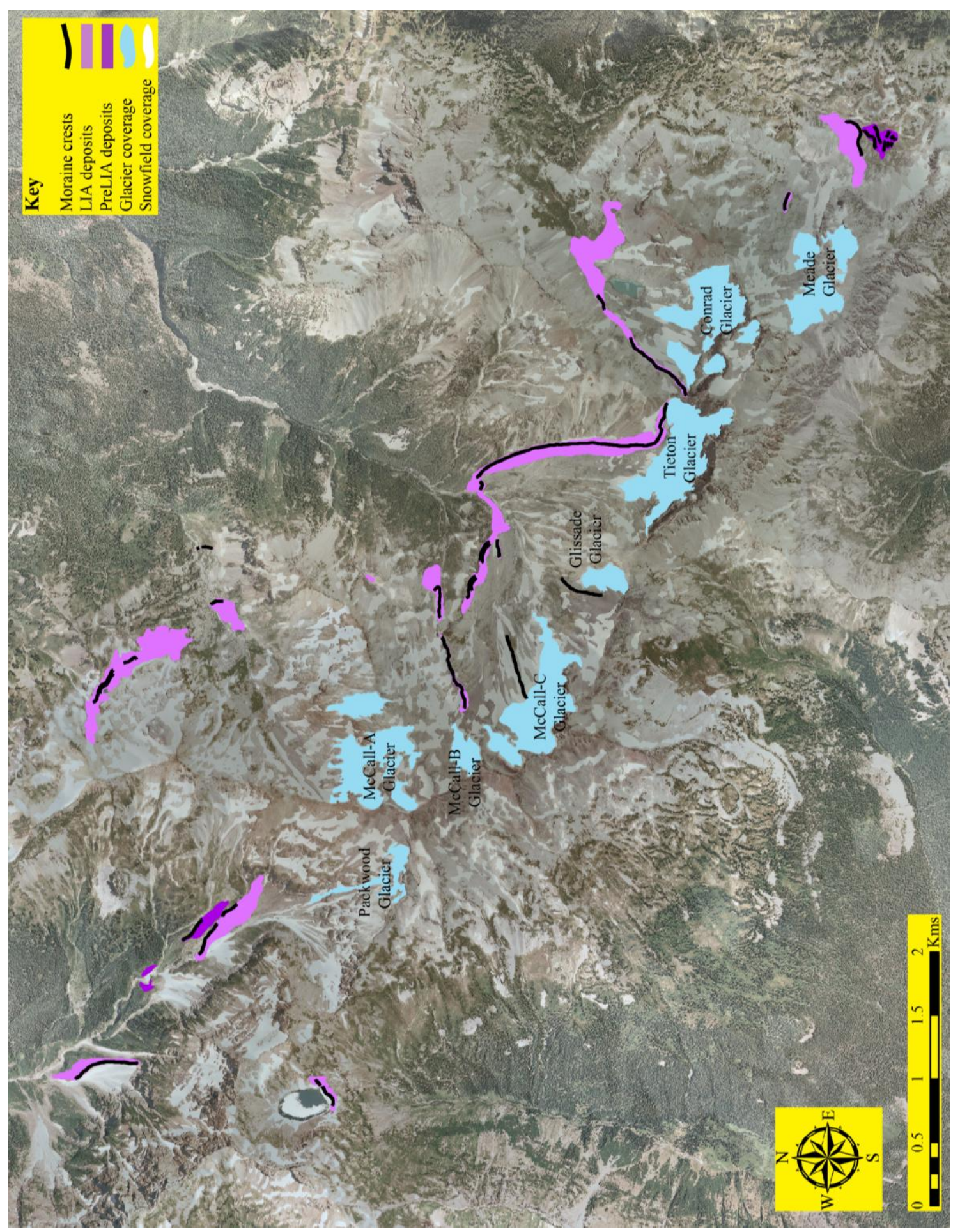

Figure 7: Glacial moraines downstream from modern and extinct glaciers near the Goat Rocks highest peaks. Photo base is NAIP imagery. See Figure 1 for larger scale location. 


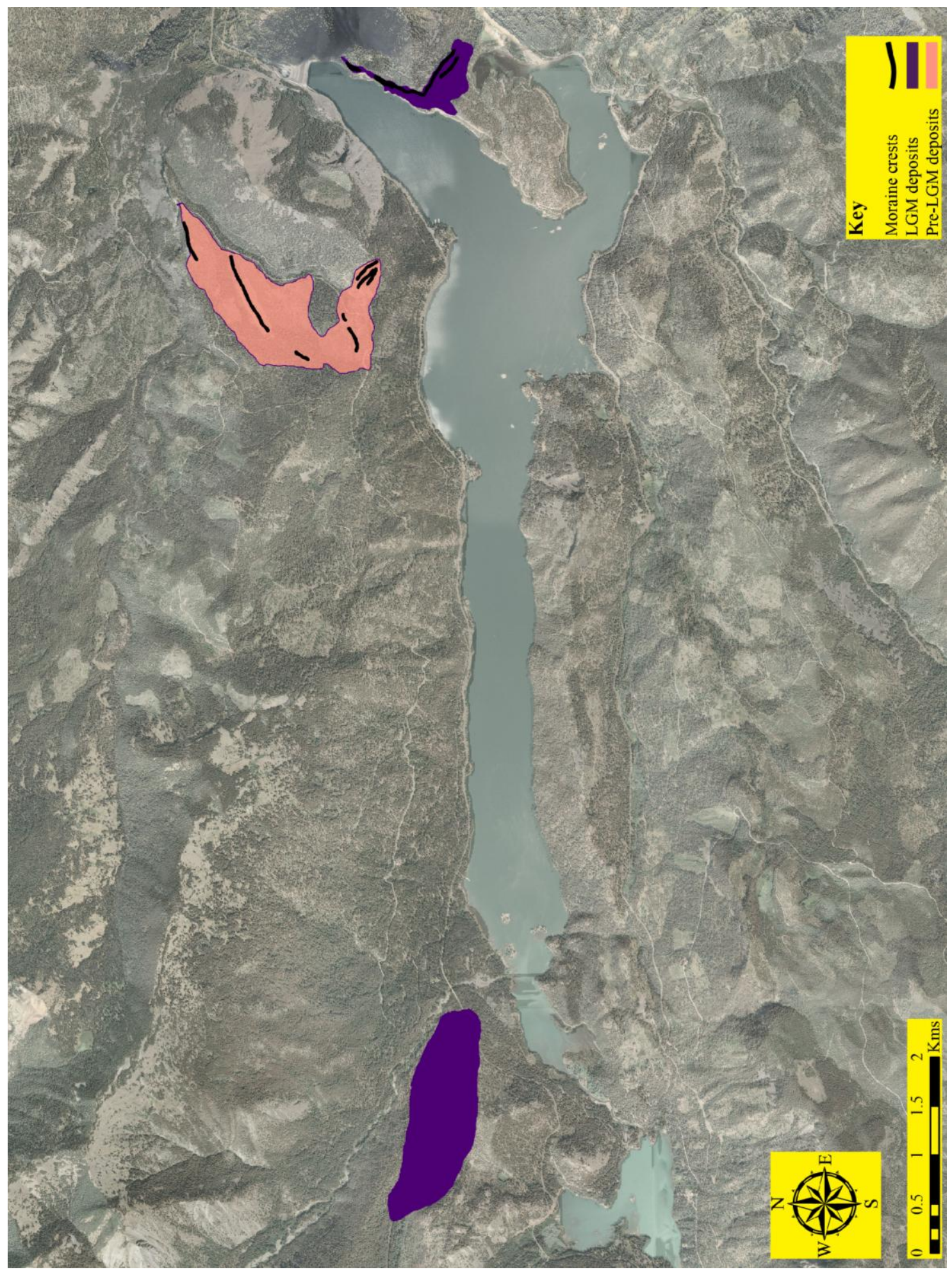

Figure 8: Glacial moraines and drift downstream $\sim 25 \mathrm{~km}$ northeast of source area. Photo base is NAIP imagery. See Figure 1 for larger scale location. 


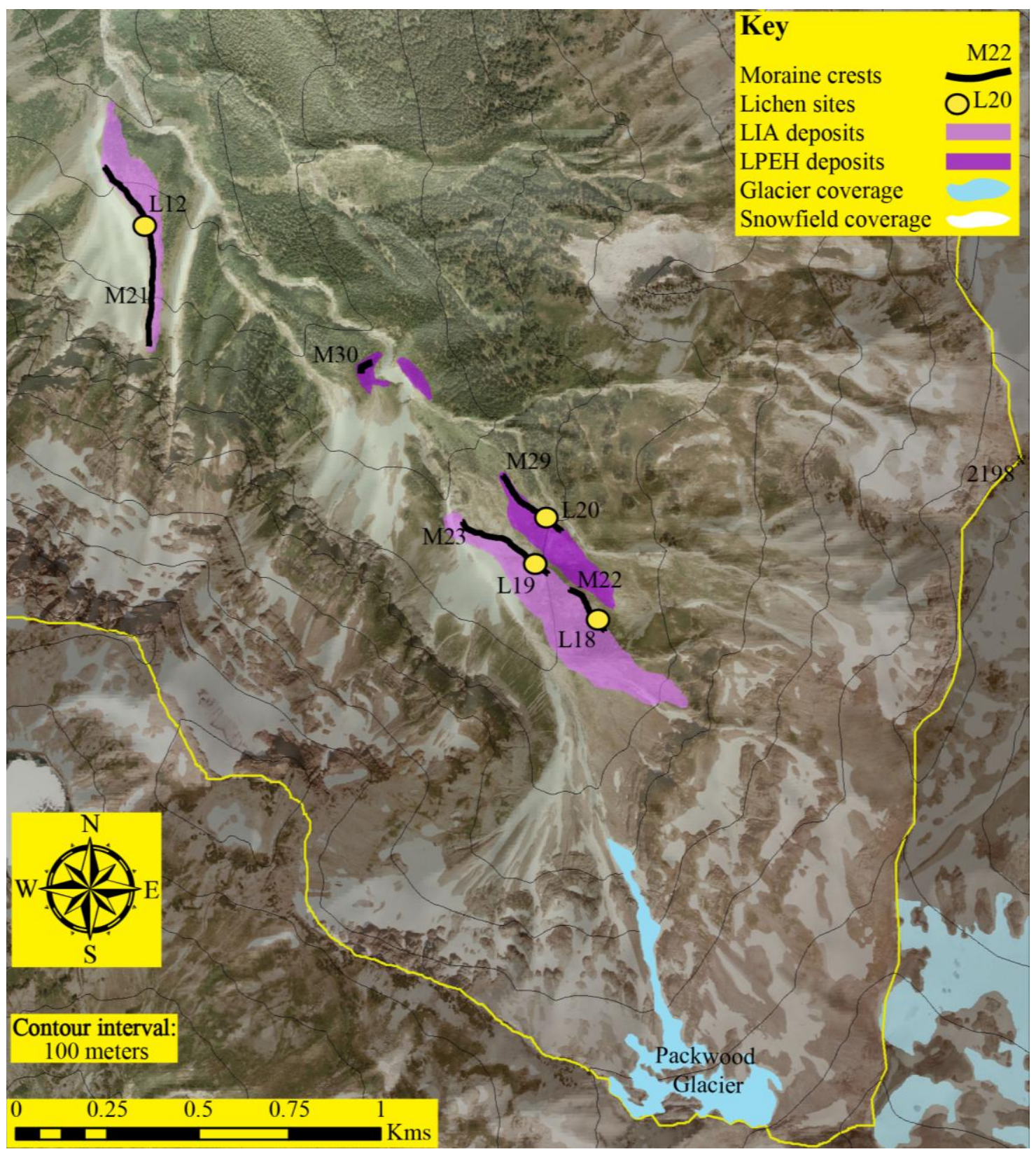

Figure 9: Aerial image of the Packwood Glacier Basin. Downstream from Packwood Glacier rest moraines crests and associated deposits (including their ages) as well as the locations of lichen measurement collection. Photo base is NAIP imagery. See Figure 2 for larger scale location.

Resting downstream from moraines M22 and M23, I believe moraines M29 and M30 were deposited by an older paleo-glacier, based on stratigraphic position. M29 contains lichens too large to fit to the Cascade growth curve accurately but, if 
extrapolated along the linear regression line, would be 175 years old. However, the lichens are probably older ( 200-300 years old) since the growth rate of lichen beyond 145 years in age exponentially slows (O’Neal, 2005). This rules out the accuracy and, thus, the application of linear extrapolation to such extents. Moraine M29 is characterized by proximal slope angles averaging $22.3^{\circ}$ and vegetation cover of greater than $75 \%$. High degradation, soil thickness, and vegetation cover indicate that moraines M29 and M30 were deposited after the Packwood Glacier reached a maximum position during a cold period at least hundreds of years before the LIA.

\subsubsection{McCall-A Glacier Basin}

Two terminal moraines (M15 and M16) and a nested moraine (M17) were deposited by the extinct Upper McCall Glacier to the east of Packwood Glacier and the Cascade divide (Figure 10). Lichen populating moraines M16 and M17 (lichen sites L2 and L6) suggest that the Upper McCall Glacier reached a maximum extent between 94 and 117 years BP (Table C, Appendix C). Moreover, lichen growing on moraine M15 (lichen site L1) indicate that it was deposited 65 to 85 years BP. The lichenometric dates for moraines M15, M16, and M17 are used here as minimum ages because they rest at high elevation and are covered by excessive snow coverage for much of the year.

A prominent terminal moraine (M2) lacking a lichen population was deposited by McCall Glacier-A (Figure 11). M2 contains an average slope of $30.8^{\circ}$, less than $10 \%$ vegetation cover, and less than five $\mathrm{cm}$ of soil (Table B, Appendix B). This suggests that it was probably deposited during the LIA. Notably, it is possible that the Upper McCall 
Glacier, that deposited moraines M15, M16, and M17, coalesced with McCall Glacier-A at the height of the LIA. Thus, it may be that moraine M2 was deposited at nearly the same time as moraines M15 and M16.

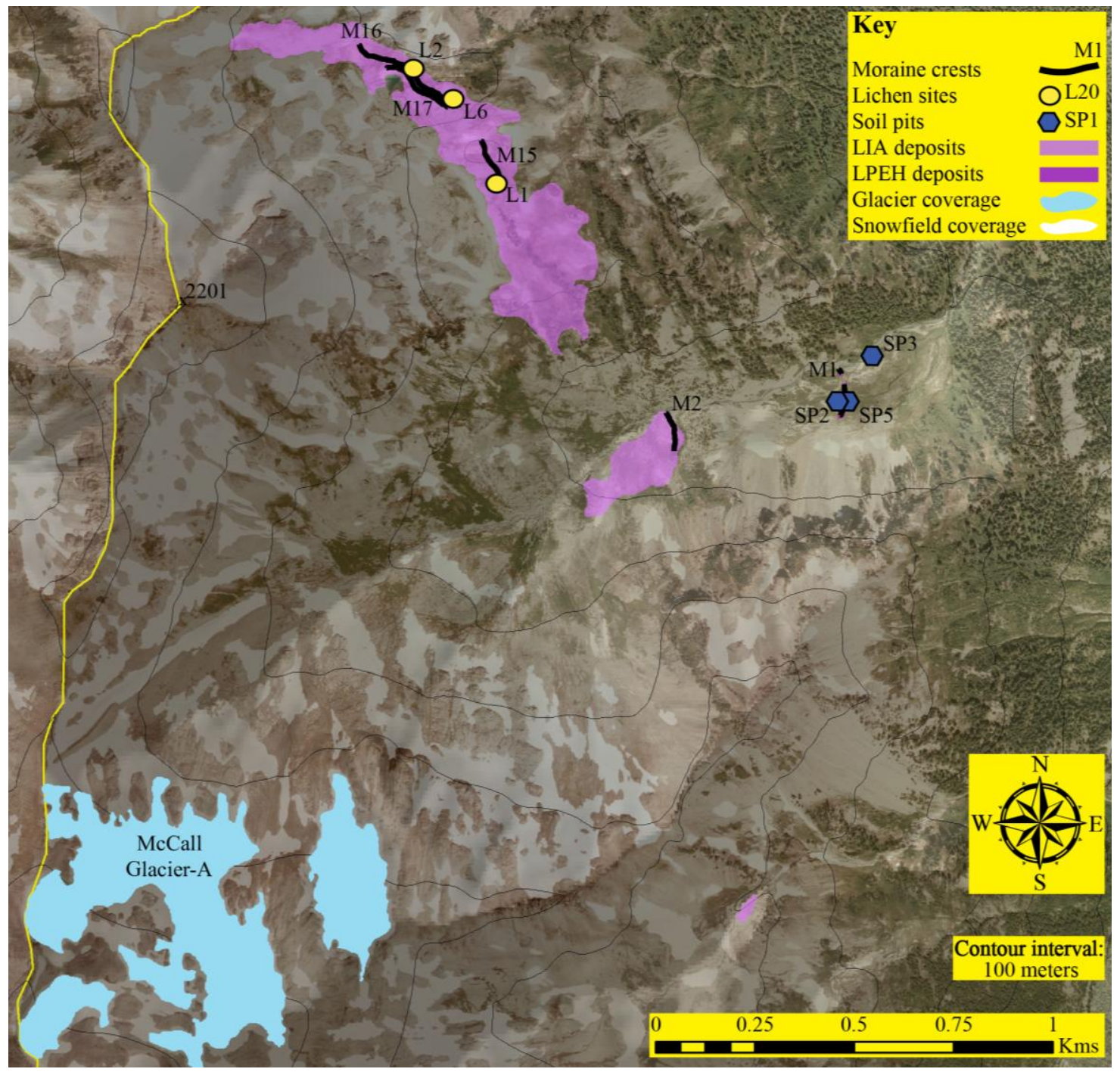

Figure 10: Aerial image of the McCall-A Glacier basin. Glacially deposited left lateral and terminal moraines and their associated deposits (including their ages; the age of M1 is LPEH), the locations of lichen measurement collection and soil pit sites rest downstream from McCall Glacier-A. Notice the two terminal moraines located directly downstream from McCall Glacier-A. Terminal moraines are sparse in the Goat Rocks Wilderness. Photo base is NAIP imagery. See Figure 2 for larger scale location. 


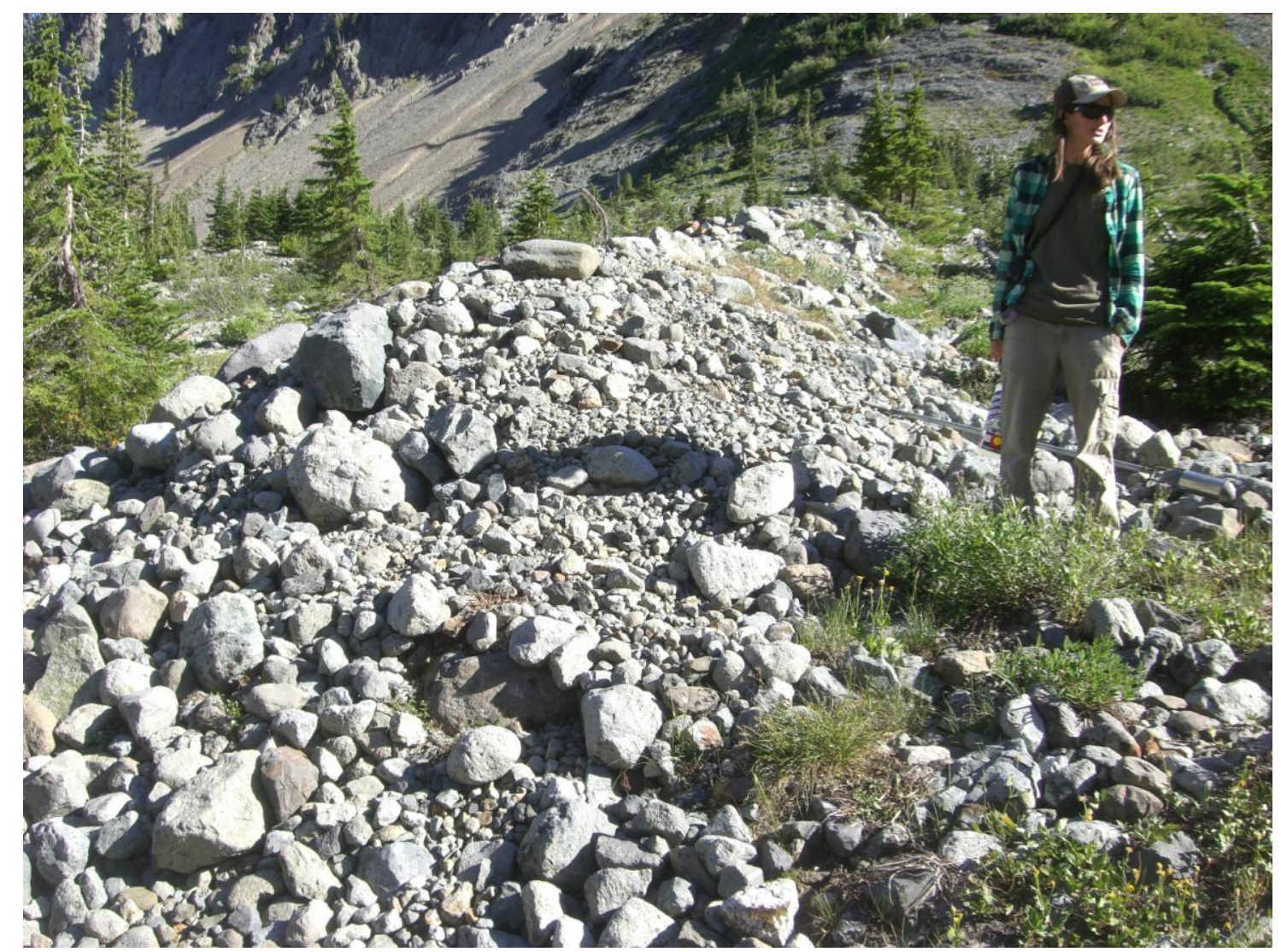

Figure 11: Terminal LIA moraine (M2) located downstream from the McCall-A Glacier. Note the lack of vegetation and soil cover suggesting recent deposition.

A large terminal moraine (M1), downstream from moraine M2, is characterized by an average proximal slope angle of $24.4^{\circ}$, greater than $75 \%$ vegetation cover, and greater than $50 \mathrm{~cm}$ of soil (Figure 12; Table B, Appendix B). These characteristics suggest the moraine is relatively old. Two soil pits (SP2 and SP5) were dug into moraine M1, one in the crest and one in the upstream foot slope. The shallow depth of weathering (Bw) and the lack of an A horizon in SP5, on moraine M1, indicate that eolian processes may be responsible for removing much of the surface soil (Figure A-6, Appendix A). SP2 has a deeper depth to weathering because it rests in a position of higher material accumulation (Figure A-3, Appendix A). The lack of surface boulders prohibited lichen 
measurements. Downstream from M1, soil pit SP3 contains volcanic tephra that superimposes glacial outwash from M1 and is dated as MSH W (1480 AD) (Table D, Appendix D). This implies that M1 was deposited before the Little Ice Age.

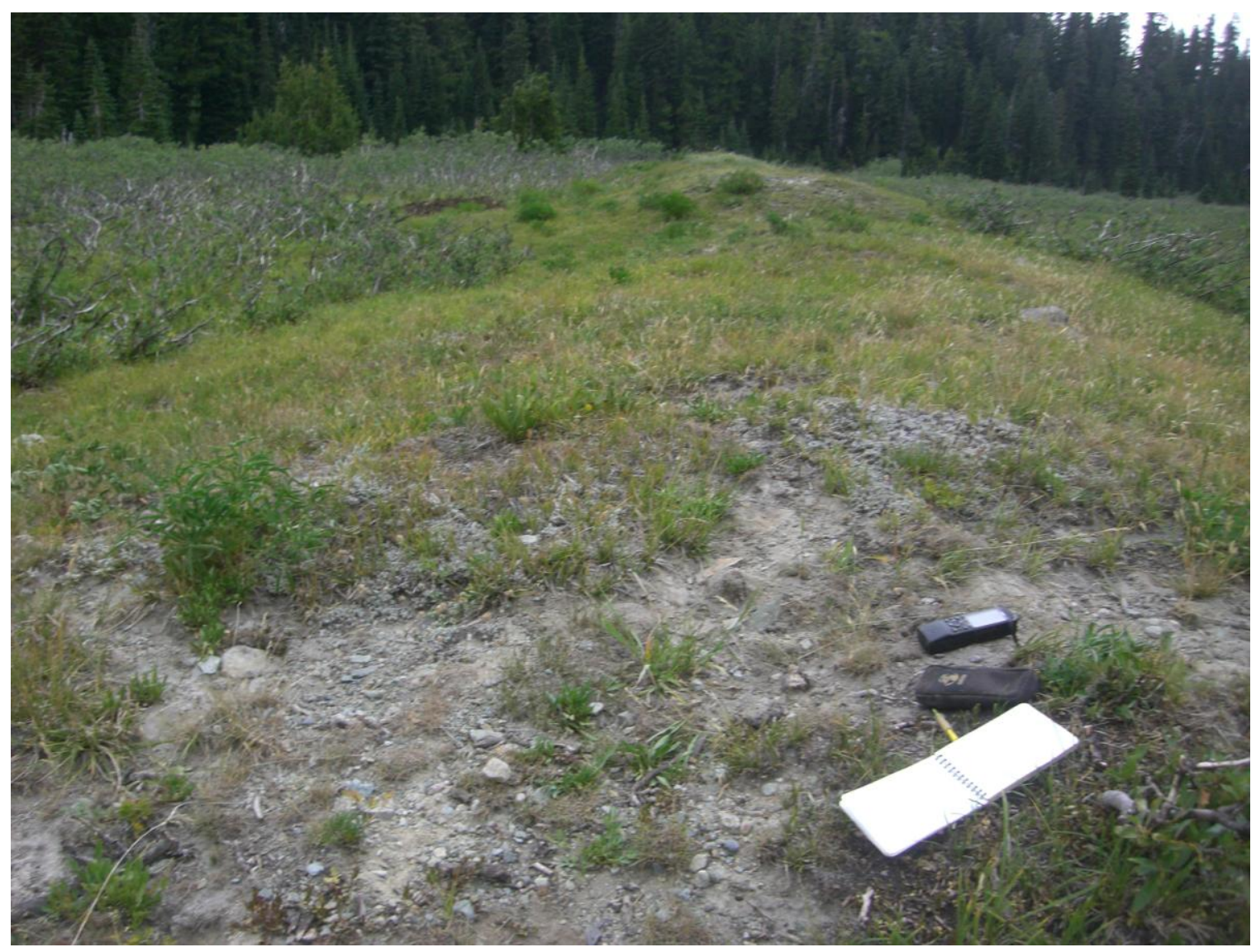

Figure 12: Terminal LPEH moraine (M1) located downstream from the McCall-A Glacier. This moraine typifies physical characteristics of an early Holocene or YD deposit. Notice the degraded and rounded crest, abundant vegetation cover and lack of surface boulders indicating soil accumulation. 


\subsubsection{Four Glaciers Basin}

The Four Glaciers Basin contains two valleys that merge together $\sim 1.5 \mathrm{~km}$ below modern glacier termini. The McCall-C Glacier, Glissade Glacier, and the Tieton Glacier reside in the one valley and the McCall-B Glacier is contained in the other (Figure 13). A medial moraine (M7) evolves into a right lateral moraine along a ridge separating the adjacent valleys (Figure 13,14). Above moraine M7 (greater than $2170 \mathrm{~m}$ ) it appears that McCall-B Glacier and McCall-C Glacier were unified in the past. Below that elevation, which marks the start of the medial moraine, the two glaciers became separate flowing into different valleys. Moraine M7 has a sharp crest and minimal vegetation and soil cover. Its surface contains lichen (lichen site L17) which, according to lichen analysis, suggests it was deposited by McCall Glacier-B between 84 and 104 years BP. (Table C, Appendix C). Thus, M7 is probably a late LIA deposit.

Two of the youngest moraines in the Goat Rocks, moraines M11 and M12, contain lichen that suggest deposition at 26 to 46 and 46 to 66 years BP, respectively (Figure 13; Table C, Appendix C). The close proximity that moraine M11 has to current terminus of McCall-C Glacier suggests that this moraine was recently vacated by glacial ice and does not represent a maximum LIA position. Moraine M12, the left lateral moraine down slope of Glissade Glacier, was probably created by a small re-advance after the LIA. This is likely as moraine M12 rests very close to Glissade Glacier's current extent and evidence downstream suggests that Glissade Glacier probably coalesced with the Tieton Glacier and McCall Glacier-C to form one glacier during the LIA. 


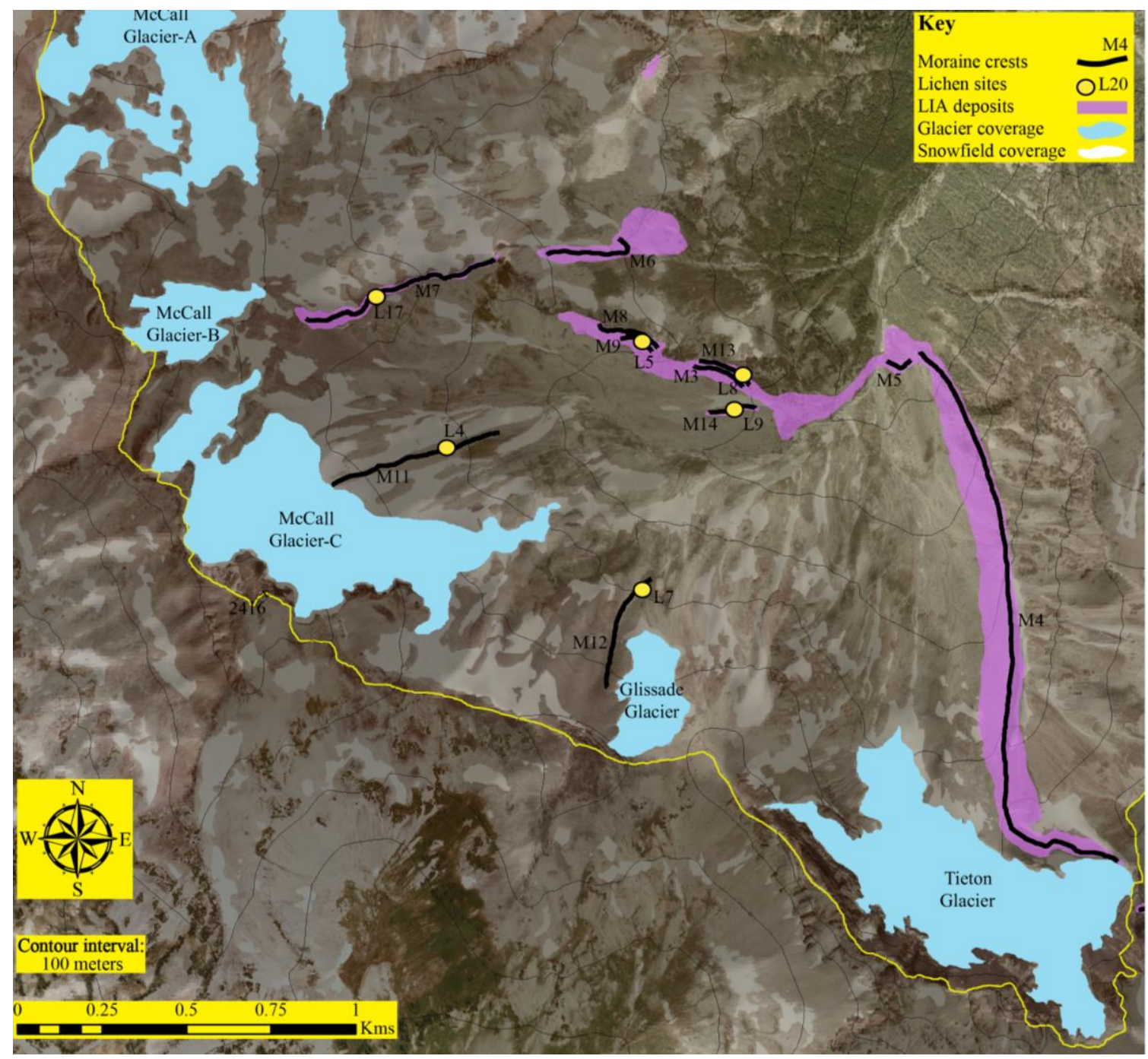

Figure 13: Aerial image of the Four Glaciers basin. Glacially deposited left lateral, right lateral, terminal, and medial moraines and their associated deposits (including their ages) as well as the locations of lichen measurement collection rest downstream from McCall Glacier-B, McCall GlacierC, Glissade Glacier and Tieton Glacier. Notice that McCall Glacier-C, Glissade Glacier, and Tieton Glacier are currently seaparate glaciers; however, appear to have coalesced as one glacier during maximum LIA extension. Photo base is NAIP imagery. See Figure 2 for larger scale location. 


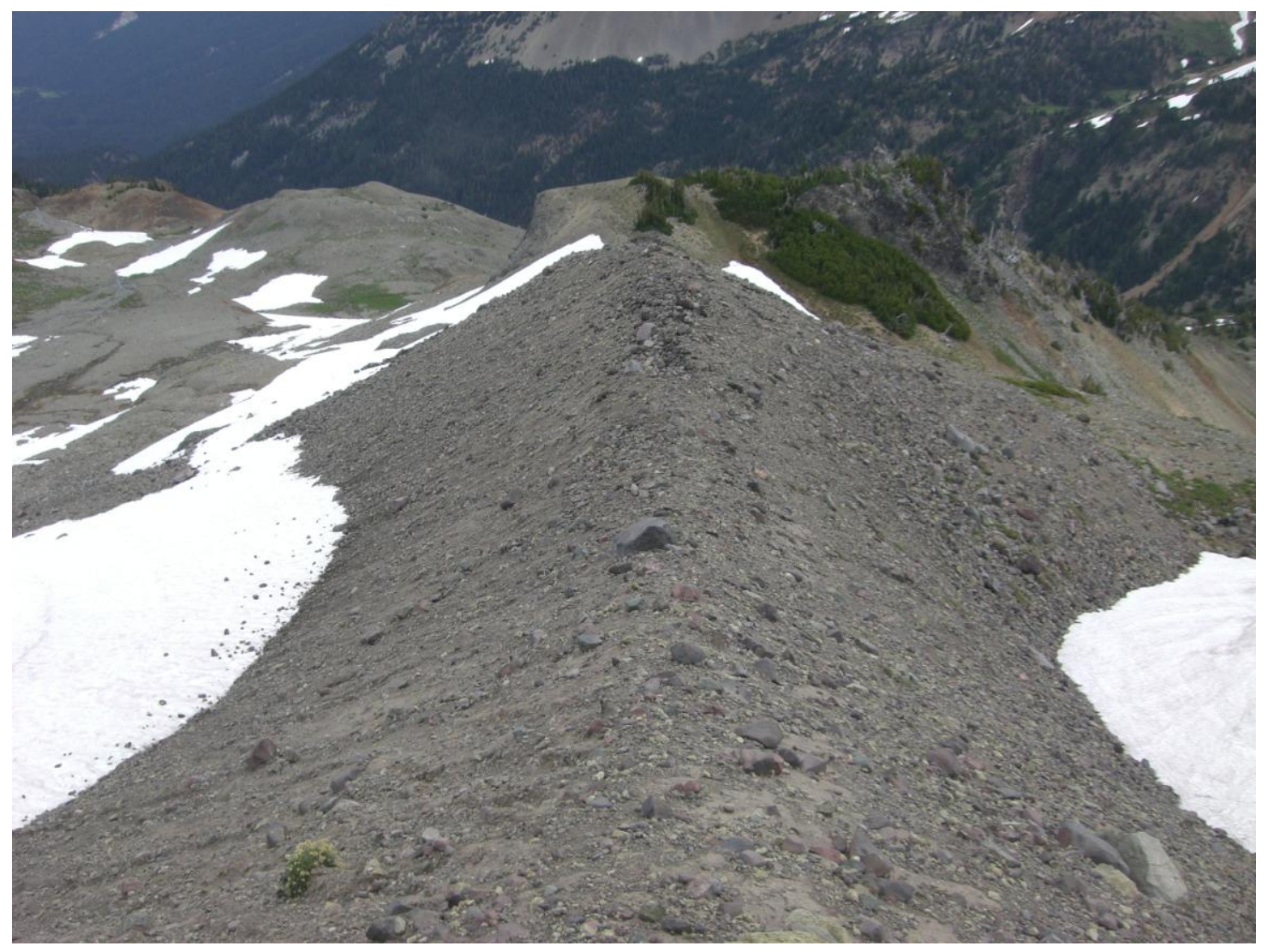

Figure 14: The medial moraine (M7) evolves to a right lateral moraine and separates McCall-B Glacier from McCall-C Glacier. Notice the lack of vegetation, sharp crest, and minimal soil accumulation. This suggests the moraine is relatively young.

Moraines M9, M13, and M14 reside down slope from McCall-C Glacier. Lichenometric analysis indicates that they were deposited 67 to 87,115 to 135 , and 69 to 89 years BP, respectively. Two left lateral moraines (M9 and M13) and a medial moraine (M14) probably represent LIA deposits. Moriane M9 (lichen site L5) is a nested left lateral moraine that was deposited at nearly the same time as a nested moraine (M15) below the extinct Upper McCall Glacier (Figure 13). Moraine M13 (lichen site L8), emplaced 115 to 135 years BP according to lichen analysis, probably represents the LIA maximum position for McCall Glacier-B. 
The Tieton Glacier, lying further east but in the same drainage, created the longest and tallest moraine (M4) in the Goat Rocks, probably during the LIA. The upper portion of this moraine is similar in appearance to many other young moraines in the Goat Rocks (Figure 15). However, its particularly sharp crest and steep slopes down moraine have prevented substrate (moraine till and boulder) stabilization and, hence, lichen accumulation (Figure 16). Nevertheless, moraine M4 rests at an elevation very similar to that of M8 and M13 (across the drainage), suggesting that a large glacier, created by the McCall-C Glacier, Glissade Glacier, and Tieton Glacier, once occupied that drainage (Figure 13).

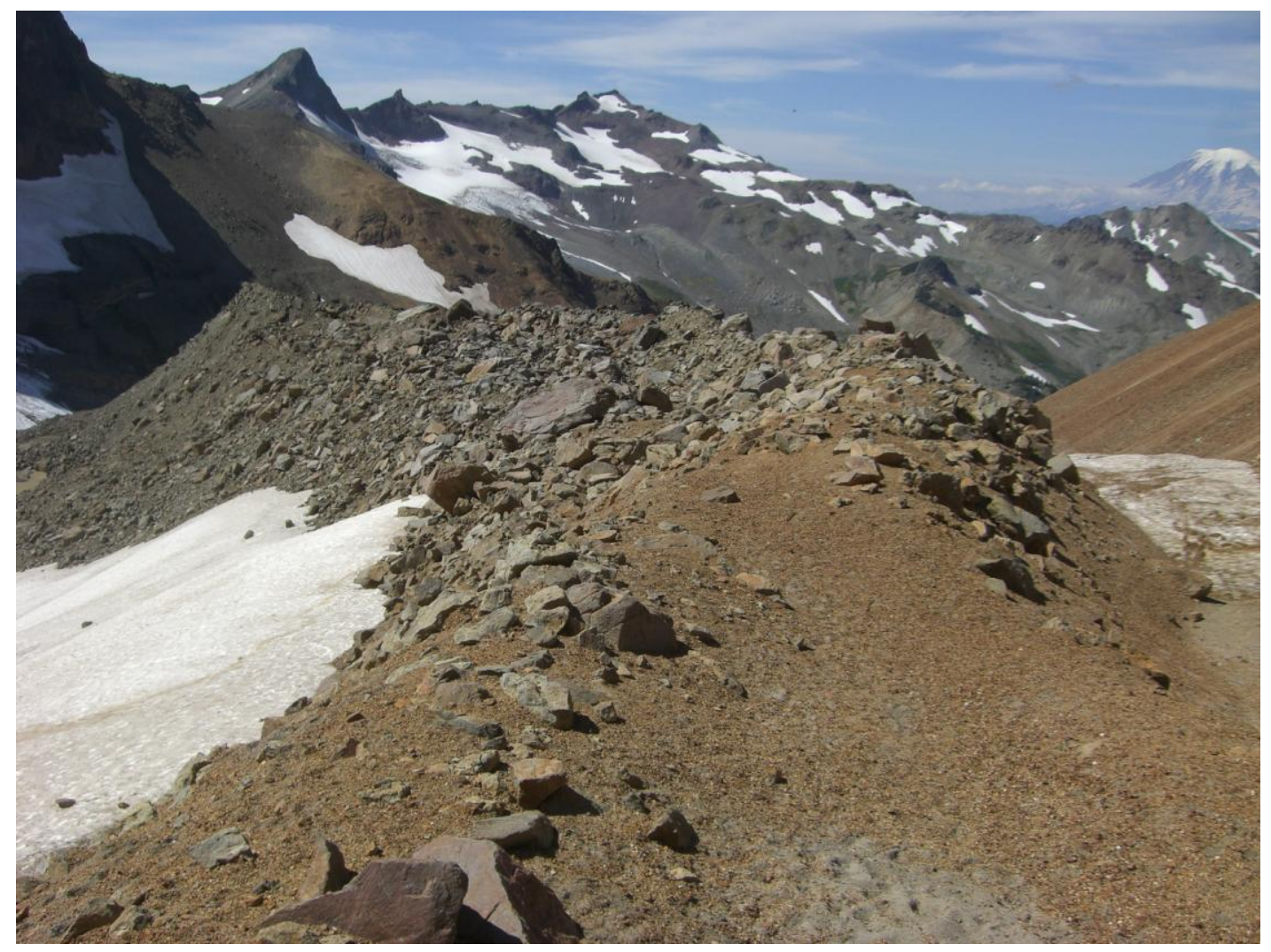

Figure 15: Large right lateral moraine (M4) downstream from the Tieton Glacier. This moraine represents the typical physical characteristics of a Little Ice Age moraine. Notice the lack of vegetation, sharp crest, and very little soil accumulation. 


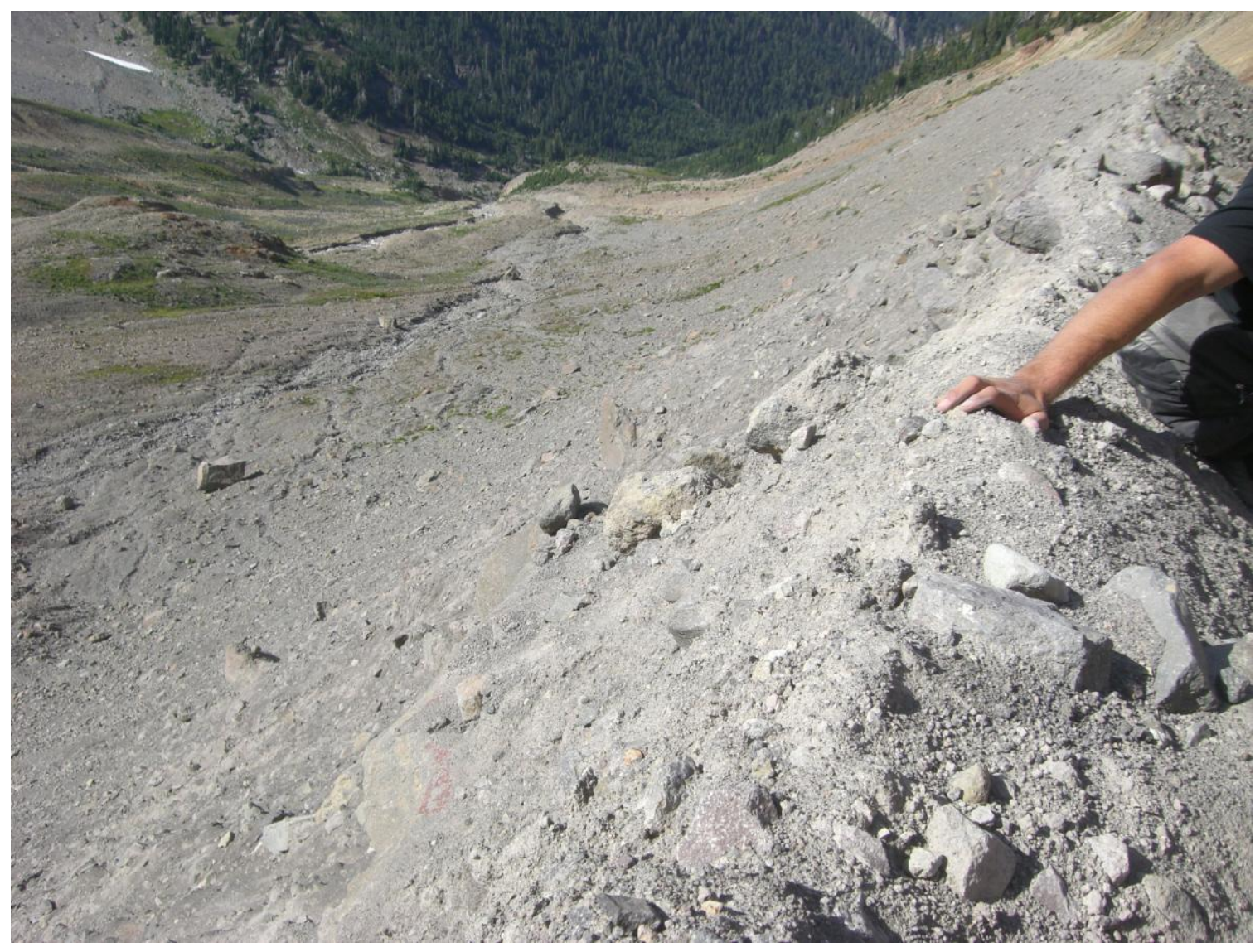

Figure 16: Atop the Tieton Glacier's right lateral moraine (M4) looking downstream northward. Note the distinct crestal sharpness.

Glacial melt from the McCall-B Glacier, McCall-C Glacier, Glissade Glacier, and Tieton Glacier creates the headwaters of the North Fork Tieton River. five km downstream from glacial termini the headwaters reach a bowl shaped basin where paleolake sediments reside (Figure 17). These sediments were recovered to a depth of $108 \mathrm{~cm}$. The first $13 \mathrm{~cm}$ of the core is composed of brownish orange (Munsell color 10YR 5/6) fine grained and oxidized sand and silt sized sediments (Figure A-1, Appendix A). The rest of the core, from 13 to $108 \mathrm{~cm}$, is comprised of alternating silt and clay sized laminated sediments that may be varved. The laminated sediments range in color from 
light grayish brown to grayish brown (10YR: 4/1, 5/1, 5/2,5/3, 6/1 and 6/2). Over 330 laminations, varying from 0.1 to $1.1 \mathrm{~cm}$ thick, were counted (Figure 18; Figure A-1, Appendix A). The uninterrupted continuity of these laminations and their thicknesses commonly represent sediments found on the bottom of deep, long lasting lakes (D. Clark pers. comm.). However, it is not known exactly how deep the lake was or how long the lake existed because its base level was undetermined and the oldest and deepest lake sediments were not discovered.

To determine if the sediments are varved two absolute ages (typically determined by radiocarbon dating organics) are required so that the number of varves between those ages can be counted. Because only one absolute age was attained from the core, establishing that the core sediments are varved was not possible. Nevertheless, if the sediments are varved the core represents $\sim 332$ years of lake deposits. Generally, the shallowest lake sediments were sandy silts which altered with depth to silts and clayey silts. Woody debris, collected at $61 \mathrm{~cm}(341$ total $\mathrm{cm})$ deep, was radiocarbon dated at 14.1 to $13.9 \mathrm{ka} \mathrm{Cal} \mathrm{BP}$ (Beta Lab \# 300558). Since the woody debris settled in the shallowest sediments of the ancient lake bottom, the radiocarbon age likely represents the late stages of the lake's existence. 


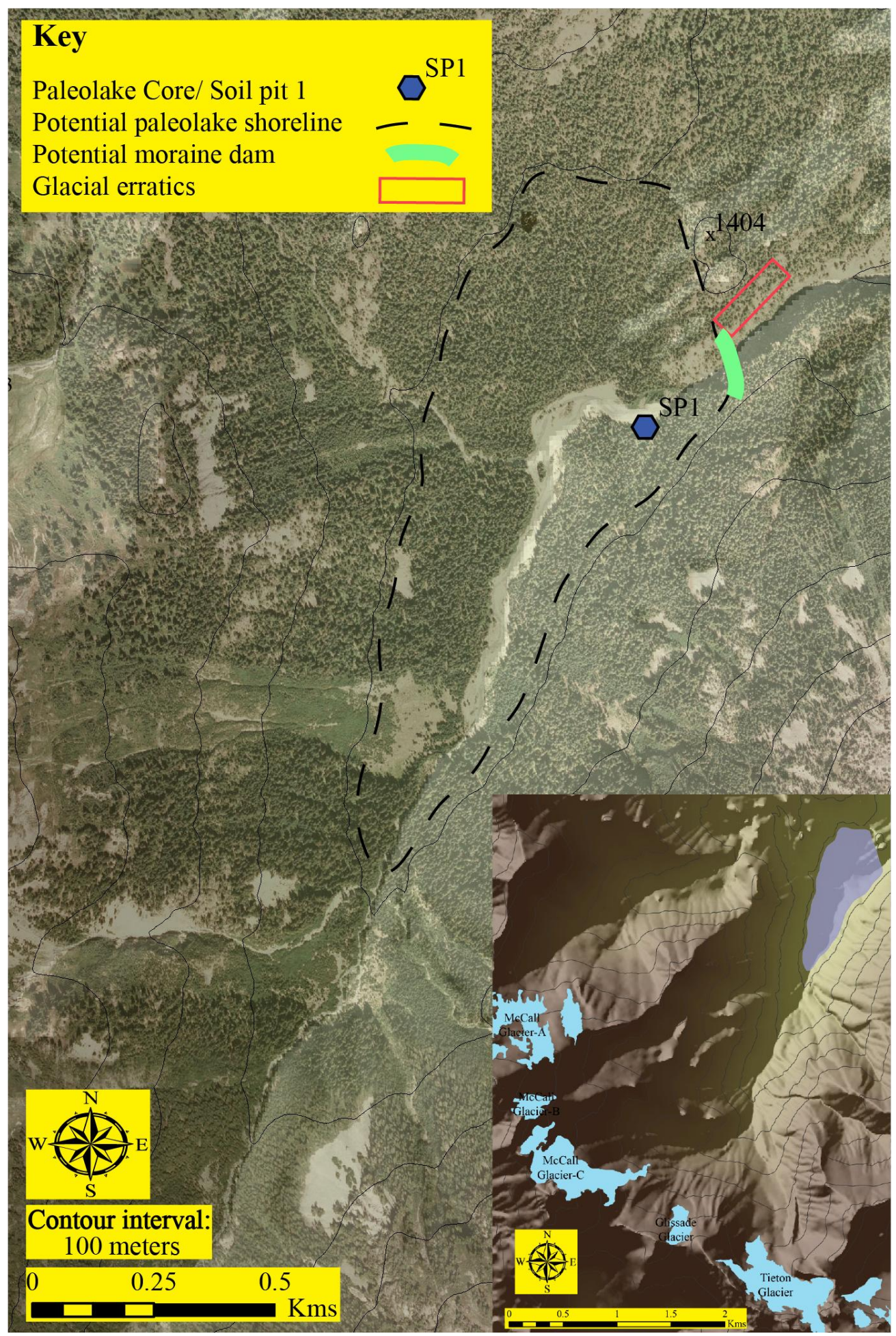

Figure 17: Geomorphic map of paleo-lake in McCall Area. Located downstream from McCall Glacier-B, McCall Glacier-C, Glissade Glacier, and Tieton Glacier (Inset) is the site of SP1 containing paleo-lake laminated sediments. The elevation of the potential lake shoreline is $\sim 1390 \mathrm{~m}$. 


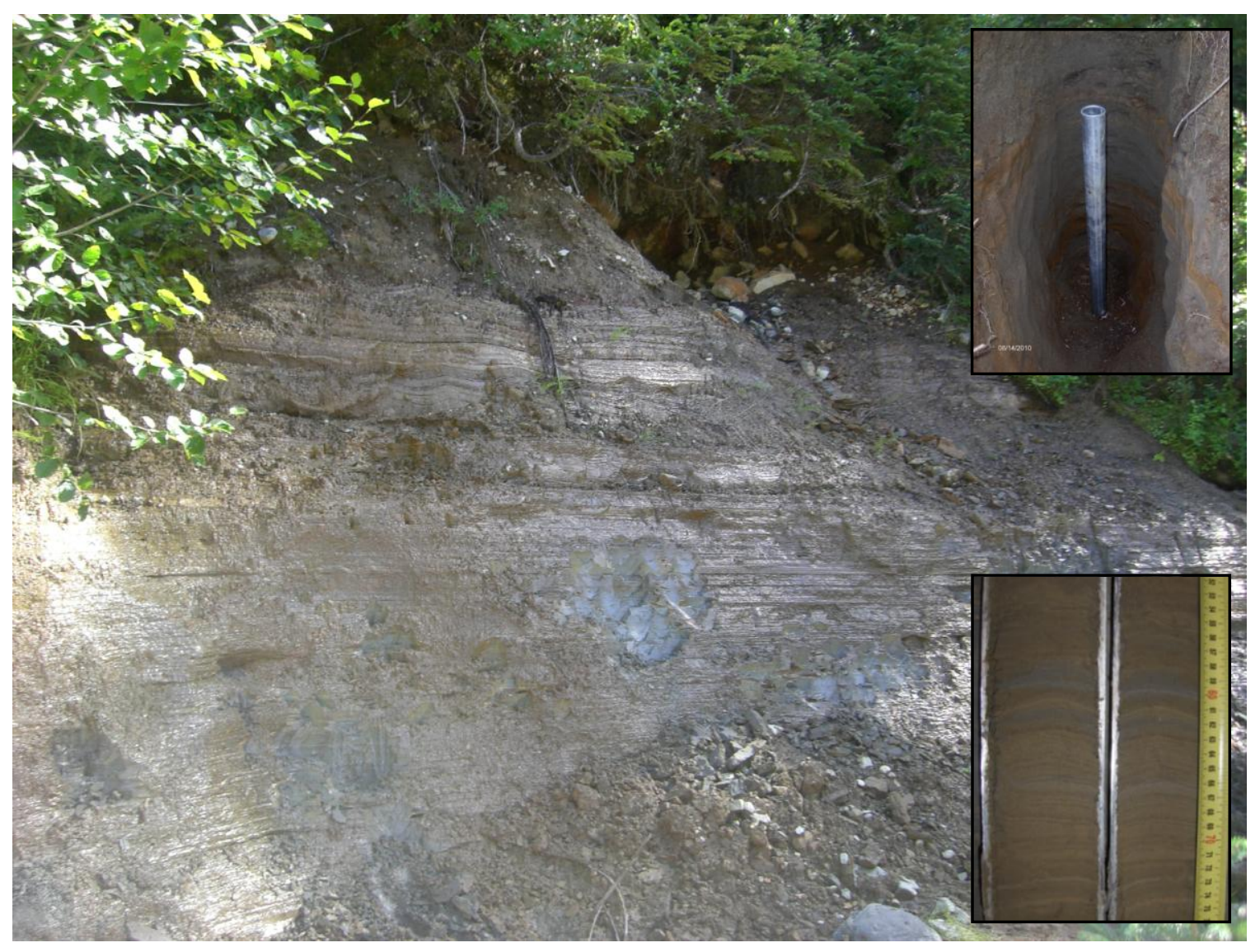

Figure 18: Outcrop of paleo-lake sediments located downstream from the Tieton Glacier on the north fork of the Tieton River. For scale, the outcrop is $\sim 3 \mathrm{~m}$ in height. The inset in the upper corner shows the beginning stages of extracting the lake sediments at the bottom of SP1. The inset in the lower corner shows a close-up of the laminated sediments.

The circular basin, in which the lake sediments were deposited, lies just upstream from a steep and narrow canyon through which the north fork of the Tieton River currently drains (Figure 17). Both sides of the canyon are steep walls that rise more than $75 \mathrm{~m}$ above the present river level. Glacial erratics reside near the top of the northern canyon wall. While it is unknown how deep the paleo-lake sediments extent below current river level, I estimate, based on the elevation of glacial erratics (i.e. elevation of terminal moraine), that the lake could have been up to $100 \mathrm{~m}$ deep. 
Since the lake sediments are located just upstream from the narrow canyon it is likely that the entrance to the canyon was dammed at some point at the end of the Pleistocene. The dam was likely created by a large glacier either during late stages of ablation as a recessional moraine or when a glacier reached its maximum extension as a terminal moraine. Both cases would create a moraine dammed lake.

If a terminal moraine created the ice-dammed lake, it is unclear whether this event occurred prior to the YD or after. If the canyon dam was glacially created, it may be that the LGM glacier, which advanced to Rimrock Lake, is responsible for the lake's creation (Figure 25). Alpine glaciers in western North America began to withdraw no later than $\sim 16 \mathrm{ka} \mathrm{BP}$ and were rapidly retreating by the Bølling Transition (14.67 ka BP) (Severinghaus and Brook, 1999), and it is possible that glaciers in the Goat Rocks also retreated at that time. This hypothesis is supported by the radiocarbon age of the woody debris collected in the lake sediments, which suggests the lake emptied near the time of the Bølling Transition. Thus, the paleo-lake would have existed after the LGM culminated from 14.1 to $13.9 \mathrm{ka} \mathrm{Cal} \mathrm{BP.} \mathrm{If} \mathrm{the} \mathrm{lake} \mathrm{sediments} \mathrm{are} \mathrm{varved,} \mathrm{which} \mathrm{would}$ represent $\sim 330$ years of deposits, lake existence could have begun as early as $\sim 14.5 \mathrm{ka} \mathrm{yr}$ BP. The dam may have failed as a result of a warming climate before the Younger Dryas, which would have increased melt water raising lake level and overtopping the moraine dam.

An alterative hypothesis suggests that the lake was created after the Younger Dryas. If the canyon dam was a terminal moraine dam created as a glacier reached its maximum extent, it may have been the advancing Younger Dryas glacier that was 
responsible for its creation. This hypothesis suggests that the lake existed after the $\sim$ YD aged glaciers reached their maximum extents, which, according to Heine (1997), occurred between 13.2 and $9.9 \mathrm{ka}$ BP on Mt. Rainier. Since the woody debris from the sediment core is aged at $\sim 14 \mathrm{ka} \mathrm{BP}$, this alternative hypothesis requires the woody debris to be incorporated into the Younger Dryas glacier before the glacier reached its max extent and then released from the glacier long after the lake began to form. This hypothesis is supported by hummocky topography found near and just upstream from the paleo-lake sediments. The hummocky topography may represent old moraine deposits, however, no clear evidence of till was discovered. Notably, Heine (1997) mapped two terminal moraines nearby as Younger Dryas deposits. Unfortunately, with much effort, neither of these moraines was successfully located. Subsequent dam failure follows a similar breaching scenario but at a later date.

\subsubsection{Conrad-A Basin}

The Conrad-A basin, on the eastern side of the Goat Rocks' highest peaks, contains two left lateral moraines (M18 and M19) that were deposited by the Conrad Glacier (Figure 19). Lichen analysis on these moraines indicate that they were deposited between 22 and 32 years BP and between 87 and 107 years BP, respectively (Table C, Appendix C). M18, like the medial moraine (M11) below the McCall-C Glacier, is in close proximity to the glacier's terminus, contains a sharp crest, $<5 \%$ vegetation cover, no soil cover, and was probably recently vacated of glacier ice. Moraine M19, deposited 
below Conrad Lake, is similar in appearance to moraine M18 but because it contains larger lichen probably represents a left lateral maximum position of the LIA advance.

The Meade basin, on the south side of the Goat Rocks' highest peaks, contains a terminal moraine (M27, site of L13) that was deposited by the Meade Glacier between 102 and 122 years BP according to lichenometric analysis (Figure 19 and Table C, Appendix C). These young moraines, probably LIA deposits, are characterized by unconsolidated sediments ranging from coarse grained silt $(0.05 \mathrm{~mm})$ to angular/subangular boulders $(<2.5 \mathrm{~m})$, sharp crests, minimal soil accumulation, and sparse vegetation cover.

Two terminal moraines (M26 and M28), just beyond M27, contain lichen too large to accurately date using the Cascadian growth curve. In addition, the muted morphology, increased amount (50\%) of vegetation cover and soil coverage (> $30 \mathrm{~cm})$ of M26 and M28 indicate that they were deposited before the LIA and probably near the same time as M1 in the McCall-A Glacier basin (Table B, Appendix B). 


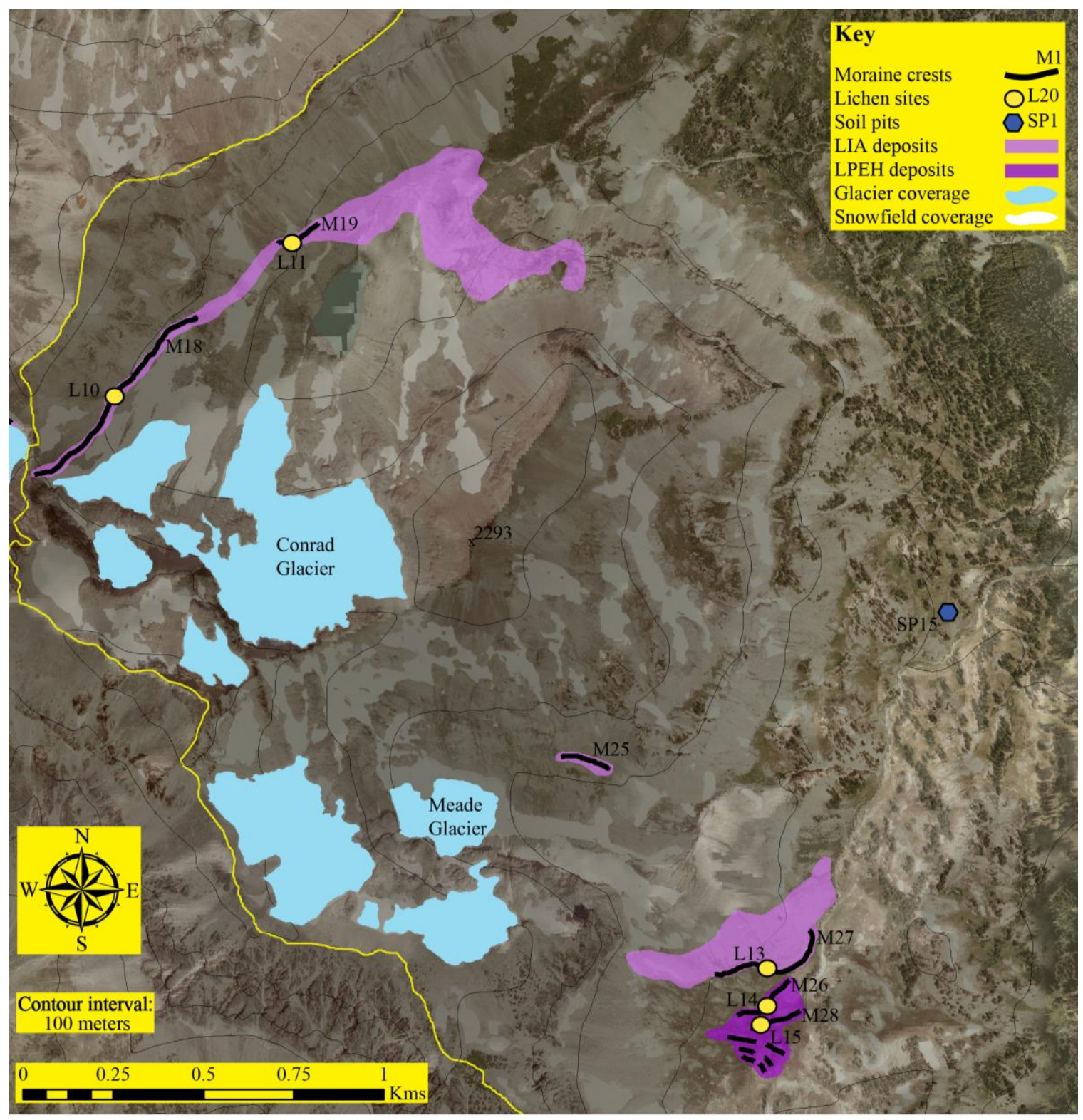

Figure 19: Aerial image of the Conrad and Meade Glacier Basins. Shown are glacially deposited left lateral and terminal moraines and their associated deposits (including their ages), the locations of lichen measurement collection and soil pit sites resting downstream from Conrad and Meade glaciers.

\subsubsection{Conrad-B Basin}

The Conrad-B basin is located $\sim 7 \mathrm{~km}$ downstream from the Conrad Glacier. According to Heine (1997), glacial deposits (YD aged) are located in the Conrad-B basin. 
Hummocky topography, indicative of degraded moraines, was found at the location of Heine's (1997) mapped moraine deposits. Four soil pits were dug just upstream, into, and downstream of the hummocks (Figure 20). However, no evidence of glacial till was discovered in any of the pits. Instead, SP12 and SP13, classified as Entisols, are poorly developed soils caused by high rates of erosion (Figures A-13 \& A-14; Appendix A). Further, my observation of boulders piled up against the upstream side of tree trunks and a loose and unstable face of andesitic brecciated tuff suggests that the hummocky terrain was formed by numerous debris flows (Figure 20). The undeveloped entisols have loose sandy and gravelly parent material supporting this hypothesis. SP14 and SP16 were dug near the hummocky terrain in a meadow and on a cutbank of a stream running through a meadow, respectively. These locations have experienced fresh accumulation of material and horizon development suggesting that the debris flows have not affected those areas recently. Neither SP12, SP13, SP14, nor SP16 contain glacial till. 


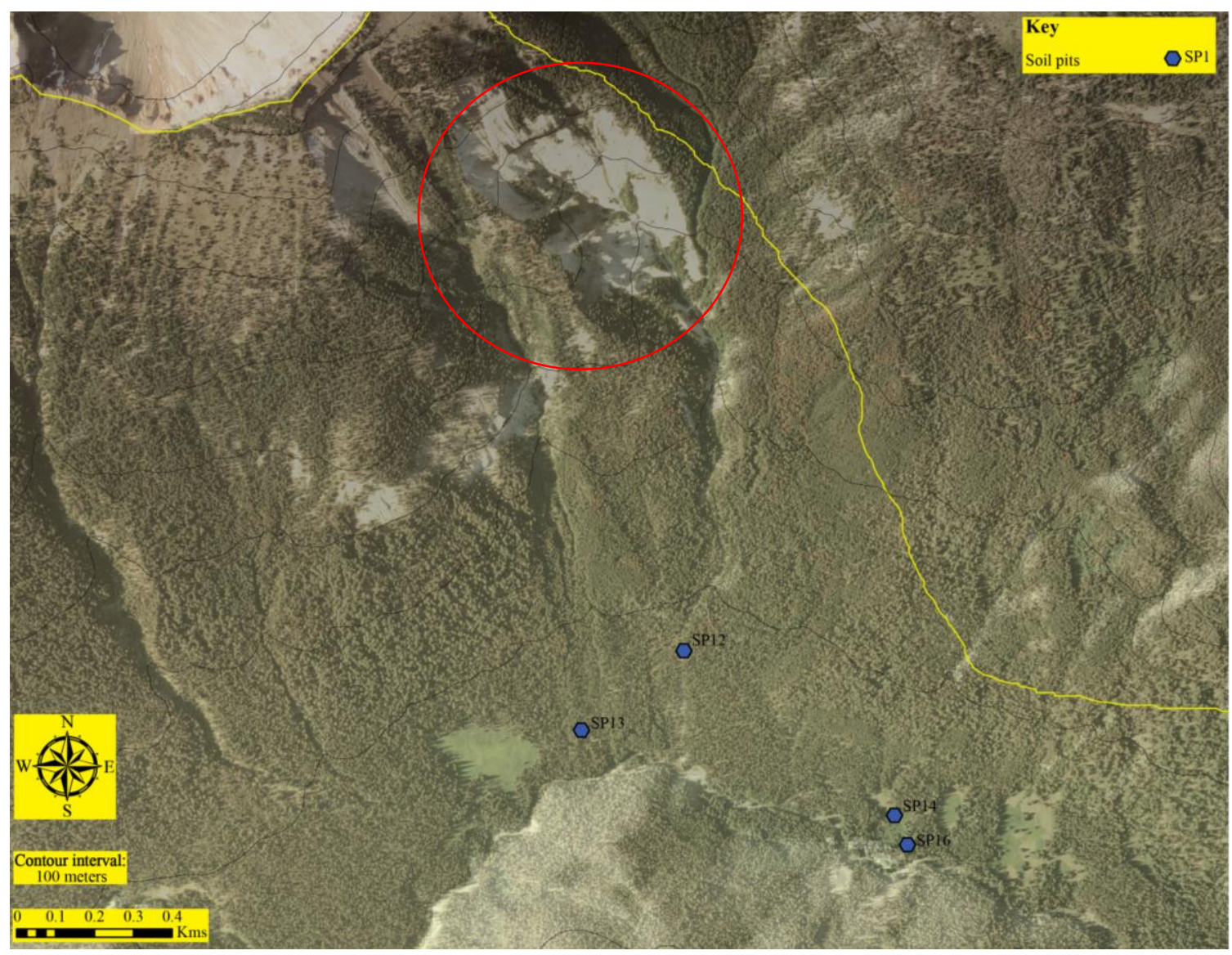

Figure 20: Aerial photo of valley downstream from the Conrad Glacier. Shown are four soil pits downstream from a unstable face of andesitic brecciated tuff (circled in red). Photo base is NAIP imagery.

\subsubsection{Snowgrass Flats and Goat Lake Basins}

One moraine (M44) was located in the Snowgrass Flats area on the southern slopes of the Goat Rocks peaks (Figure 21). Moraine M44 is characterized by minimal vegetation cover and $<5 \mathrm{~cm}$ soil cover, when present. The largest lichens were beyond constraints for dating using the Cascadia growth curve (Table C, Appendix C). It is speculated that moraine M44 may have been deposited during a small cirque glacier advance during the Holocene (i.e. Garda Age, 8.2 event) or as part of a larger advance 
during the YD. The general lack of moraines and abundance of pro-talus ramparts in the Snowgrass Flats area suggests glacial coverage was limited but impermanent snow coverage was common during the recent Holocene.

While the Snowgrass Flats area and juxtaposing areas downstream generally lack moraines, there are numerous meadows. Hotspots for soil accumulation, two meadows were chosen for soil pits (SP7 and SP9). SP7 is located $\sim 3.5 \mathrm{~km}$ downstream from Goat Lake (Figure 21). The pit contained an ash from the Mt. Mazama eruption ( $\sim 6850$ years BP) indicating glaciers failed to extend that far down valley, since that time. SP9 was dug into a meadow located on the southern slope of the Goat Rocks peaks (Figure 21; Table D, Appendix D). It contained numerous ash deposits, the oldest being the MSH P (Figure 22; Figure A-10, Appendix A). Since the meadow is representative of geomorphic activity on the south side of the highest peaks, the ash in SP9 suggests that the south side of the Goat Rocks hasn't experienced glacial activity in the last 2500-3000 years (Table D, Appendix D). This correlates well to the findings in SP4, which is also on the southern side of the Goat Rocks.

SP4 was dug into an ancient landslide residing in a cirque on the southeastern side of the Snowgrass Flats Area (Figure 21). Because the deepest ash located in SP4 was deposited 2500-3000 BP the landslide must have occurred before that time (Figure A-5, Appendix A; Table D, Appendix D). This indicates that the cirque has been void of glacial activity since before this time. 


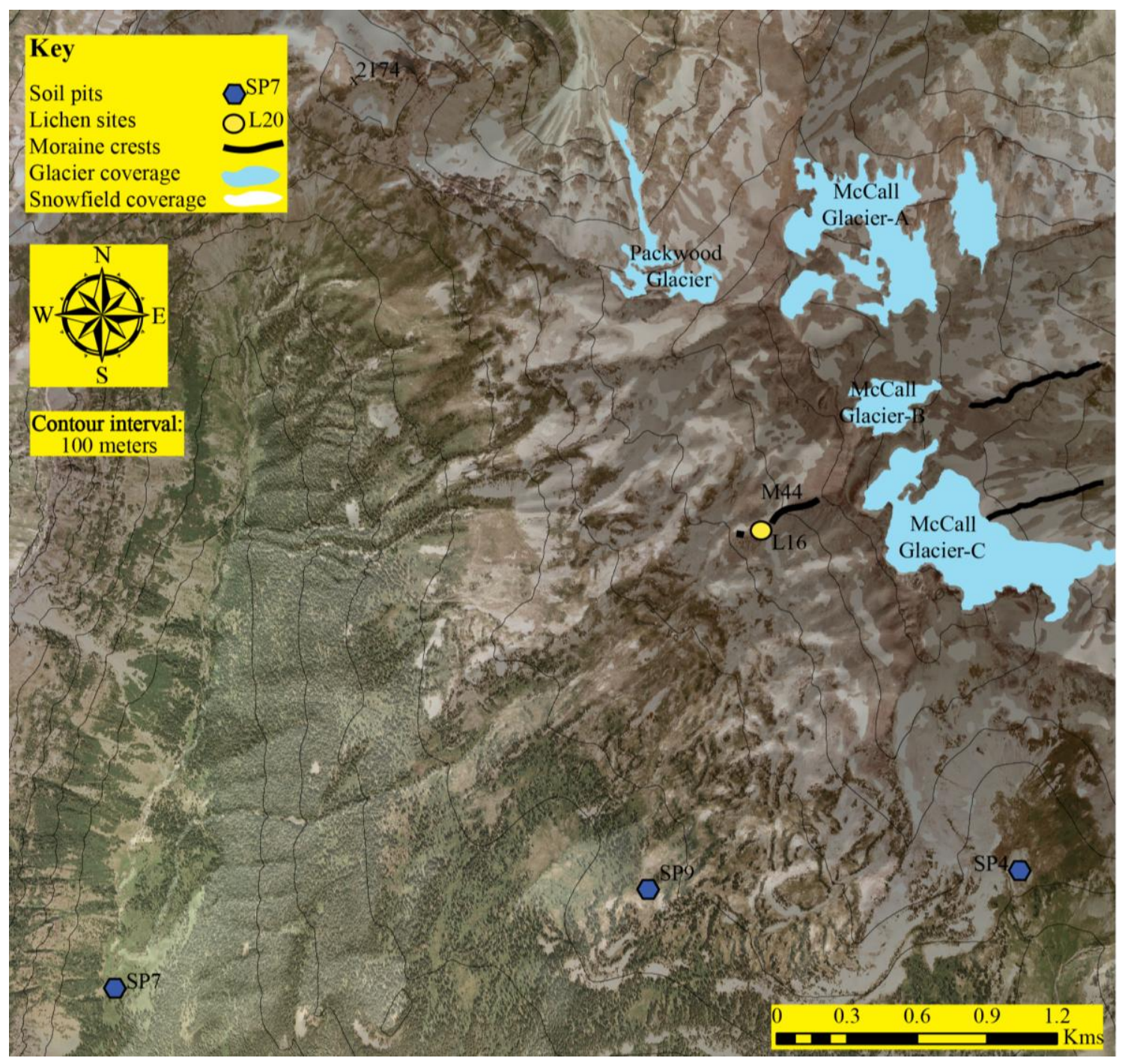

Figure 21: Aerial photo of the Snowgrass Flats Area (the south side of the Goat Rocks highest peaks). Notice the lack of mapped glacial deposits. The south side of the Goat Rocks contained very few LIA glaciers and appears to have last experienced glacial activity prior to the Late Neoglacial. Photo base is NAIP imagery. See Figure 2 for larger scale location. 


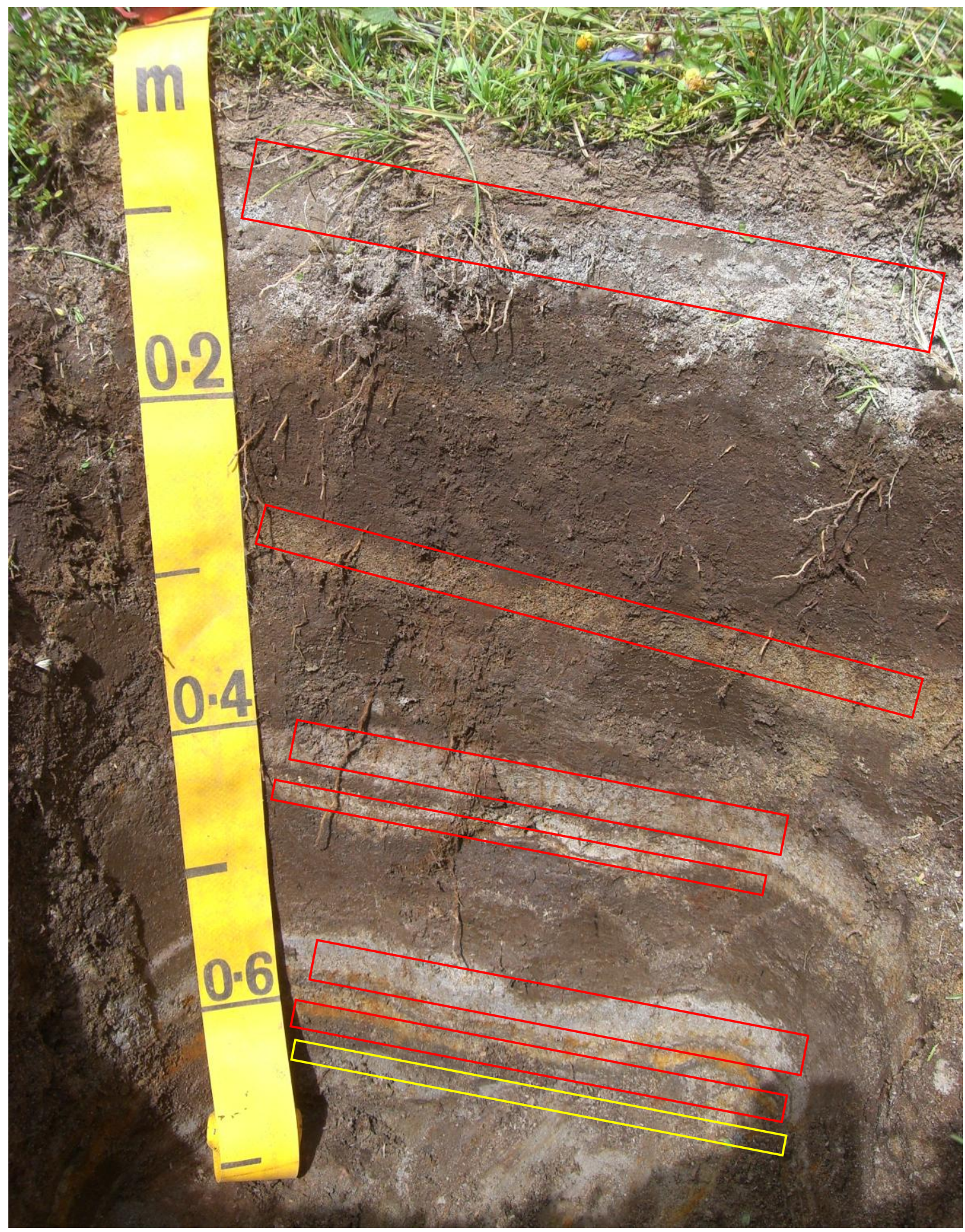

Figure 22: Soil profile of SP9 located on the south side of the Goat Rocks highest peaks in the Snowgrass Flats area. SP9 was dug on a meadow and contains numerous ash deposits. The red rectangles are volcanic ashes and the yellow rectangle is the ash deposit from the MSH P eruption. 
On northwestern side of the Goat Rocks a terminal moraine (M24) rests at the mouth of a cirque damming Goat Lake (Figure 23). A stream has eroded the moraine's eastern side allowing drainage when the lake level is high. Moraine M24 has an average proximal slope of $30.6^{\circ}$ (consistent with other young moraines in the Goat Rocks), $<10$ $\mathrm{cm}$ of soil cover, and $\sim 20 \%$ vegetation cover. A soil pit (SP8) in the proximal slope of M24 contained an abundance of MSH 1980 ash, well sorted eolian silts, and glacial till but lacked any horizonization (Figure A-9 and Table A, Appendix A). The lack of soil suggests that the moraine is young and/or conditions for soil development are poor. Lichens (lichen site L3) indicate the moraine was deposited between 102 to 122 years BP when an extinct glacier reached a maximum position probably during the LIA (Table C, Appendix C). 


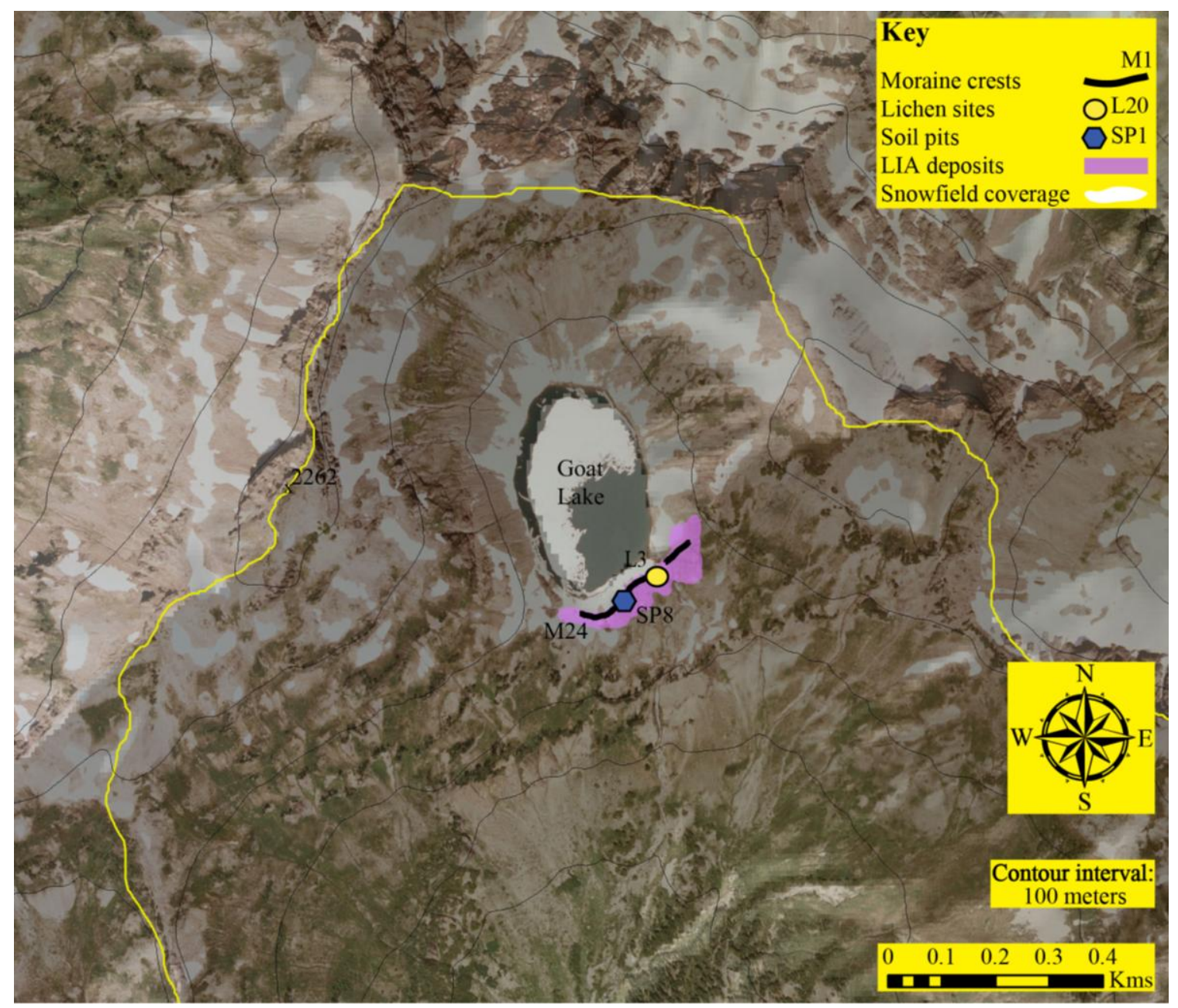

Figure 23: Aerial photo of the Goat Lake cirque, its terminal moraine and the soil pit and lichen measurements sites in the Snowgrass Flats Area. This is the only LIA-type moraine discovered on the southern side of the Goat Rocks highest peaks. The cirque lake is highly protected from direct sun exposure. Photo base is NAIP imagery. See Figure 2 for larger scale location.

\subsubsection{Walupt Lake Basin}

The Walupt Lake basin is located in the southern portion of the Goat Rocks. While no moraines were located in the valley, glacially deposited boulders are found at its higher elevations. A soil pit (SP10) was dug just downstream from the boulders in a meadow (Figure 24). SP10 contains a developed A/B/C profile with a diminutive amount 
of gravel (i.e. possible glacial till) down to $50 \mathrm{~cm}$. This, along with the lack of moraines, indicates that the Walupt Lake basin probably did not experience glacial activity during the recent Holocene. No other glacial evidence was discovered in the Walupt Lake basin.

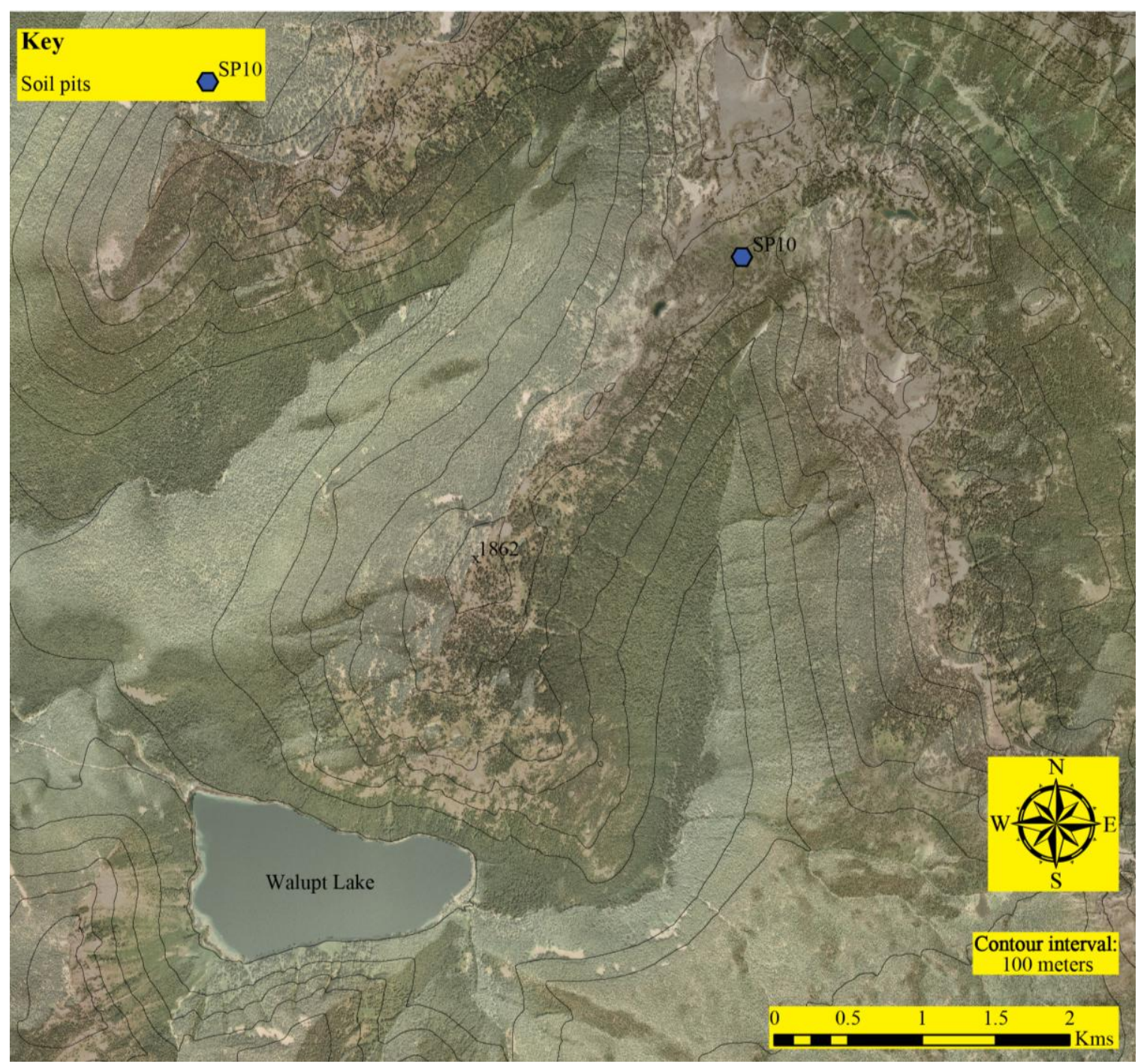

Figure 24: Aerial photo of the Walupt Lake drainage south of the Snowgrass Flats area. Shown is the location of soil pit 10 (SP10). SP10 was dug in a meadow lying down slope from a few glacial erratics but no moraines. Photo base is NAIP imagery. See Figure 2 for larger scale location. 


\subsubsection{Rimrock Lake Areas}

The outermost lateral and terminal moraines and glacial drift are found south of the Rimrock Lake dam (northeast side of lake) and northwest of Rimrock Lake, more than $30 \mathrm{~km}$ downstream from the Goat Rocks glaciers (Figure 25). Their distances from modern glacier termini indicate that glacier coverage was extensive at the time of deposition. The nested right lateral moraines south of the dam are hummocky, have subdued crests, shallow proximal slopes $\left(\sim 15^{\circ}\right)$, contain subrounded/rounded surface boulders when present, have a rich accumulation of soil and complete vegetation coverage (Figure 26). A soil pit (SP6), in the crest of moraine M34, contained the only identified accumulation of silicate clay films in the Goat Rocks (Figure 25; Figure A-7, Appendix A). The clay films on $<25 \%$ of the ped faces are indicative of alpine soils older than 10 ka years and more common in late Pleistocene aged alpine soils (Birkeland, 1999).

Moraines (M36-43) on the north side of Rimrock Lake are characterized by large subdued crests, shallow proximal and distal slopes $\left(\sim 10^{\circ}\right), 100 \%$ vegetation cover and > $50 \mathrm{~cm}$ of soil cover (Figure 25; Table B, Appendix B). Because they rest $\sim 200 \mathrm{~m}$ higher and appear more degraded than those on the southeast shore of the lake, I suggest they may be from a more extensive advance before the LGM. 


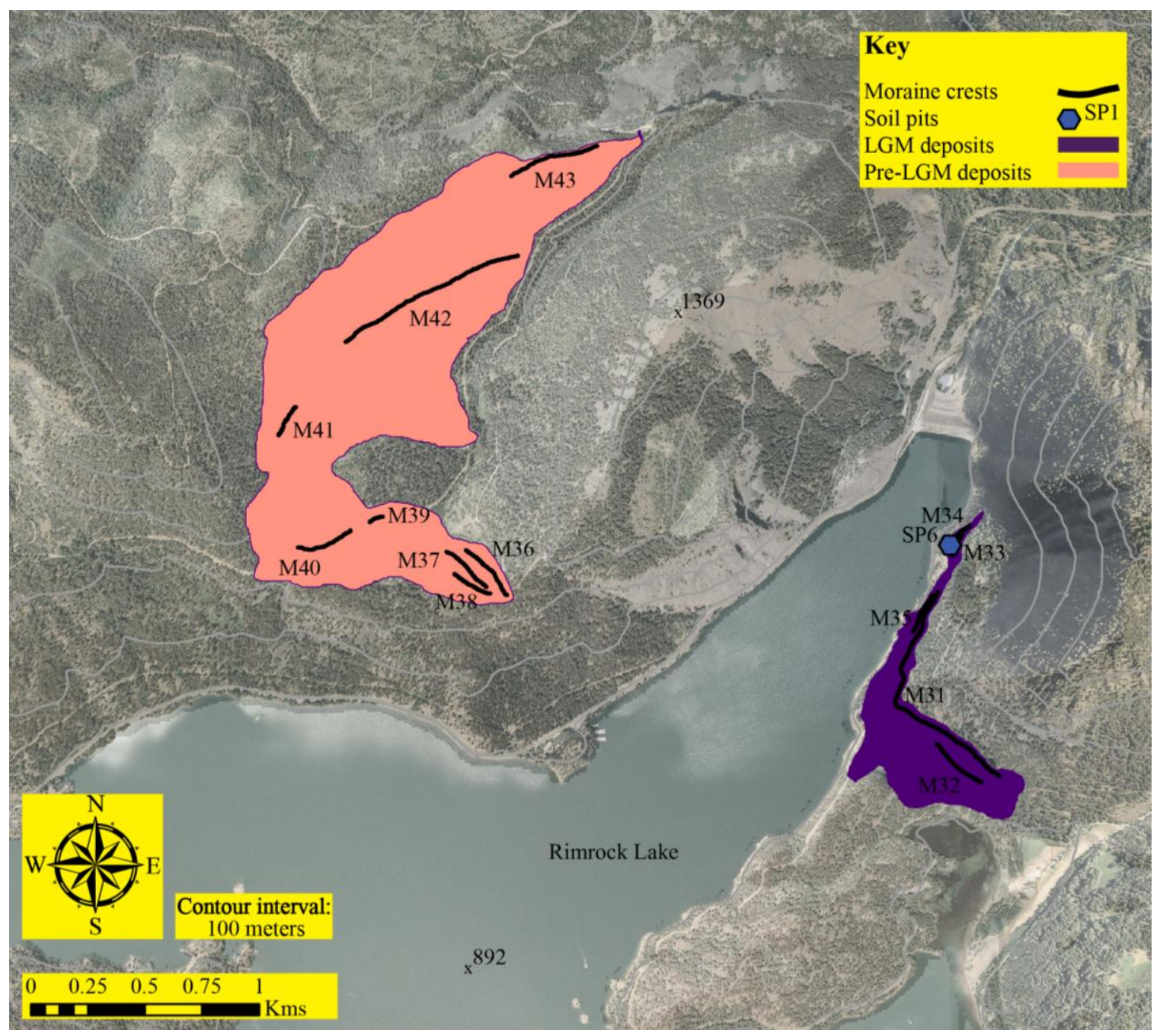

Figure 25: Aerial image of moraines near the Rimrock Dam in the Rimrock Lake Area. These moraines are over $25 \mathrm{~km}$ downstream from the Goat Rocks glaciers. The lake elevation is $892 \mathrm{~m}$ asl. 


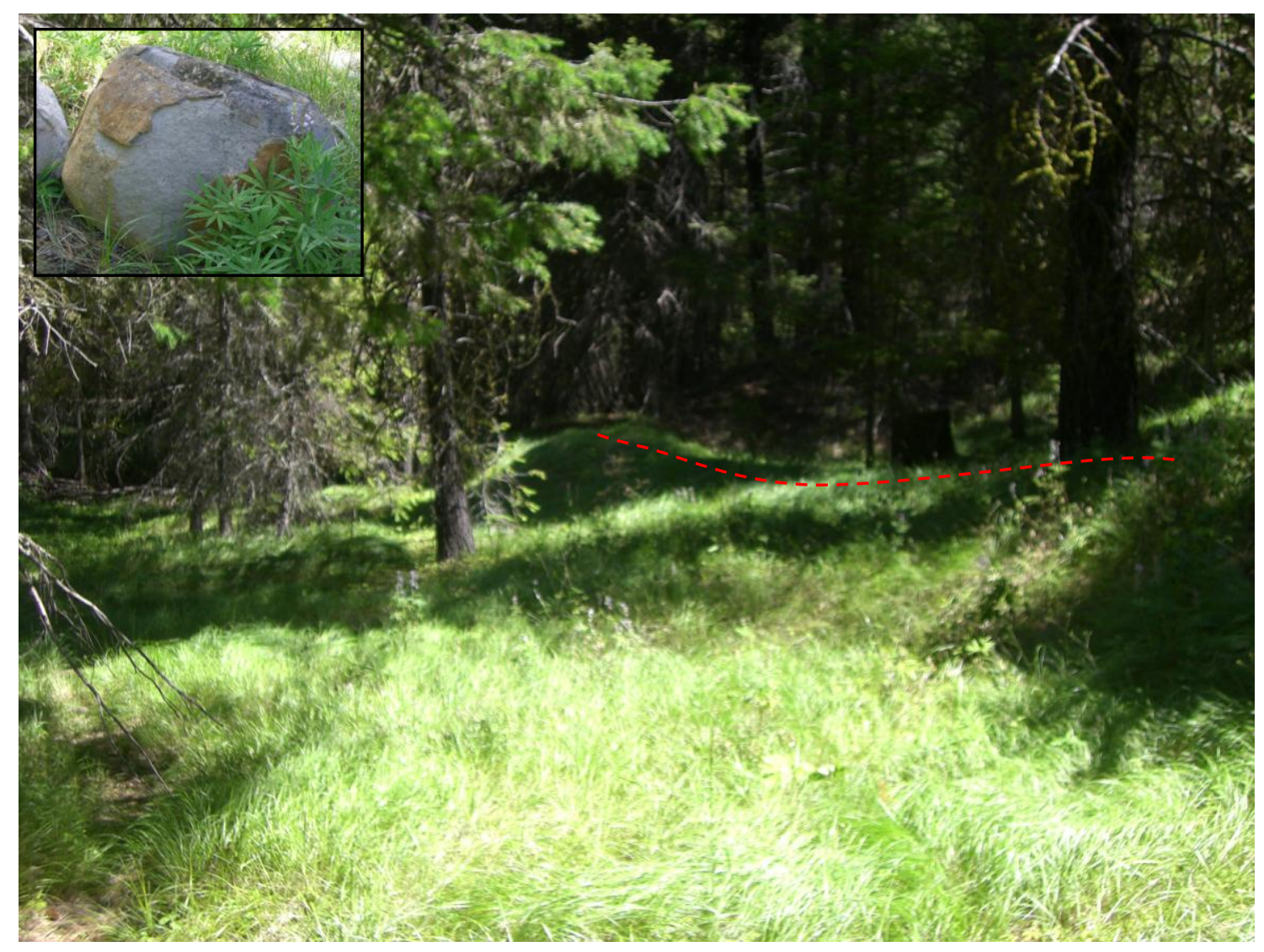

Figure 26: Right lateral hummocky moraine deposited near the Rimrock Lake Dam. This moraine represents the typical physical characteristics of a LGM-type deposit. The inset in the upper left corner is of a highly weathered and exfoliating boulder $(1 \mathrm{~m} \mathrm{dia}$.) located just out of the figure. The red dashed line is the hummocky moraine crest.

Glacial drift is located in an area on the northwest side of Rimrock Lake (Figure 27). The distance between the glacial drift and modern glacial termini ( $>20 \mathrm{~km})$ suggests that an extensive glacial advance, LGM or older, deposited the material. While glacial till was undiscovered, highly weathered glacial drift boulders support this interpretation. Soil pit (SP11), in a meadow containing drift, has a thick $(>50 \mathrm{~cm}) \mathrm{Bw}$ horizon but no identifiable clay films (Figure A-12, Appendix A). The thick Bw horizon supports soil accumulation possibly since the LGM while the lack of clay films argues against it. 


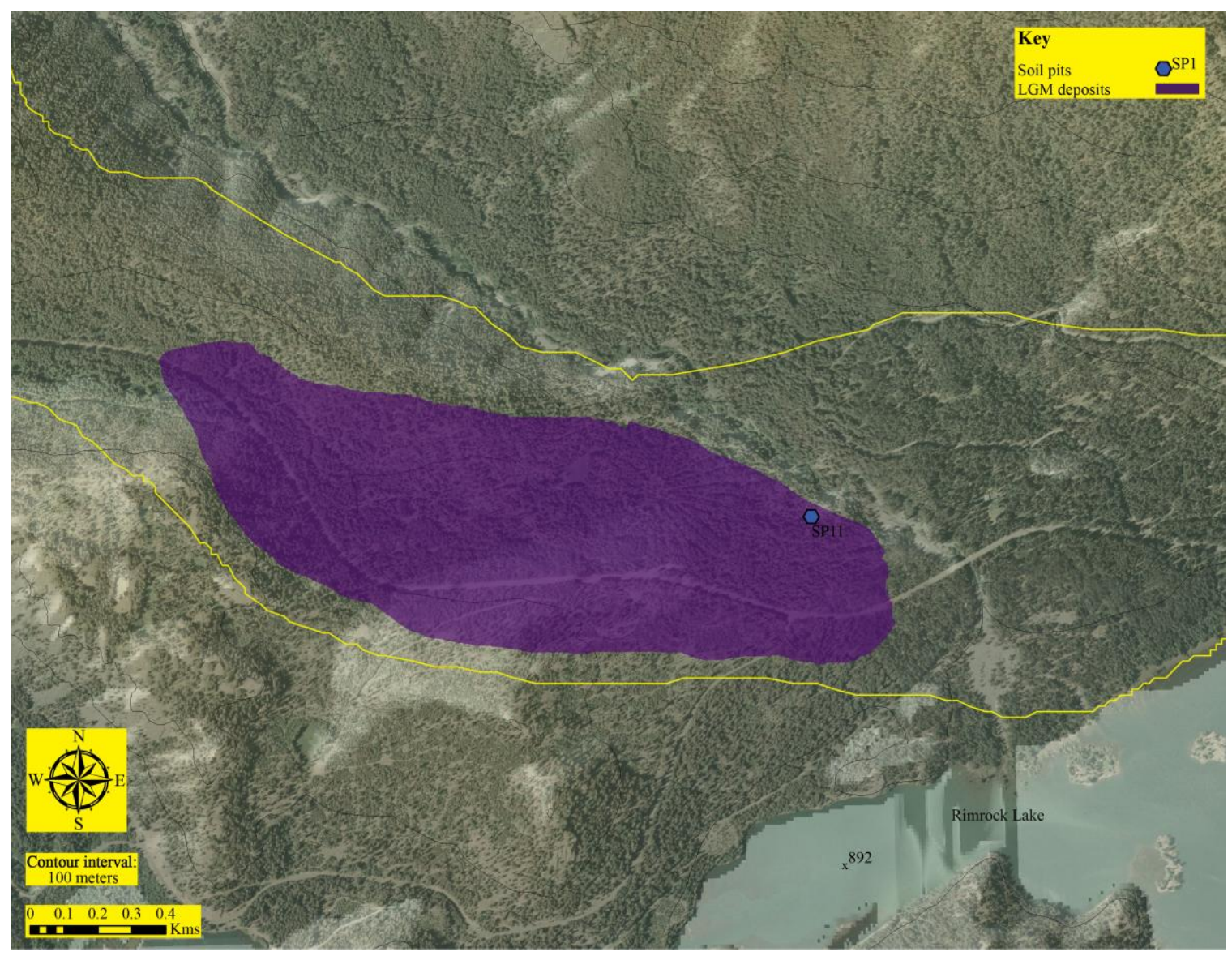

Figure 27: Aerial map of glacial drift near the inlet of Rimrock Lake. Shown is soil pit 11 (SP11) which was dug in a meadow surrounded by drift.

\subsubsection{Summary of results}

Based on the results discussed above, Goat Rocks pro-glacier deposits can be placed into three relative age groups (from youngest to oldest): Little Ice Age (LIA), late Pleistocene-early Holocene (LPEH), and the Last Glacial Maximum (LGM) (which includes possible pre-LGM deposits). LIA moraines are closest to modern glacier termini and are common on the north and northeast slopes of the Goat Rocks peaks. They are characterized by sharp, minimally eroded crests, little to no soil cover, and minimal 
vegetation cover. A pit dug into one of these moraines showed no soil accumulation (Table 2). These moraines contain steep proximal slopes $\left(30^{\circ}\right.$ and $\left.40^{\circ}\right)$ which are similar to other LIA deposits in the Cascades (Putkonen and O'Neal, 2006) (Figure 28). Glaciers in the Goat Rocks appear to have reached maximum LIA extent at a minimum of 94 to 114 years BP. It is a minimum age because some lichens were collected near the upper limit elevations of accurately dated lichenometric studies (i.e. Porter, 1981).

A set of late Pleistocene-early Holocene (LPEH) moraines is found between 100 and $400 \mathrm{~m}$ downstream from the LIA moraines in the Packwood, McCall, and Conrad areas. These moraines are characterized by eroded and rounded crests, an accumulation of mature soil horizons, and dense vegetation cover. Moraine material consists of unconsolidated sediments ranging from fine grained silt $(0.002 \mathrm{~mm})$ to subangular/subrounded boulders $(<1.5 \mathrm{~m})$. Depths to B horizons in two LPEH moraine pits (SP2 and SP3) are shallower that those in LGM moraine soils, suggesting they are younger (Table 2). The most common B horizons are young and weakly developed Bw horizons that are slightly reddened and lacking clay enrichment. Typically, Holocene aged moraines regularly display Bw horizons after a few thousand years of deposition. In the Colorado Front Range the youngest deposits with a Bw horizon are 3-5 ka (Birkeland, 1999). This implies that LPEH deposits were deposited at least a few ka BP. These moraines have proximal slope angles between $20^{\circ}$ and $25^{\circ}$, which is at least $5^{\circ}$ greater than LGM deposits (Figure 28). They have proximal slopes similar to the Pilgrim Cove type moraines near McCall, Idaho that are aged at 14 ka BP (Colman and Pierce, 1986). Further, Alpine Creek type moraines in the Sawtooth Mountains of Idaho have proximal 
slopes of $\sim 20^{\circ}$, similar to those in the Goat Rocks, and are aged at less than $\sim 16 \mathrm{ka} \mathrm{BP}$ (Borgert, 1999). Thus, proximal slope measurements of the LPEH moraines in the Goat Rocks indicate that these moraines were probably emplaced during the late LGM, YD, or early Holocene. Their close proximity to glacial headwalls implies they weren't deposited during an extensive advance like the LGM.

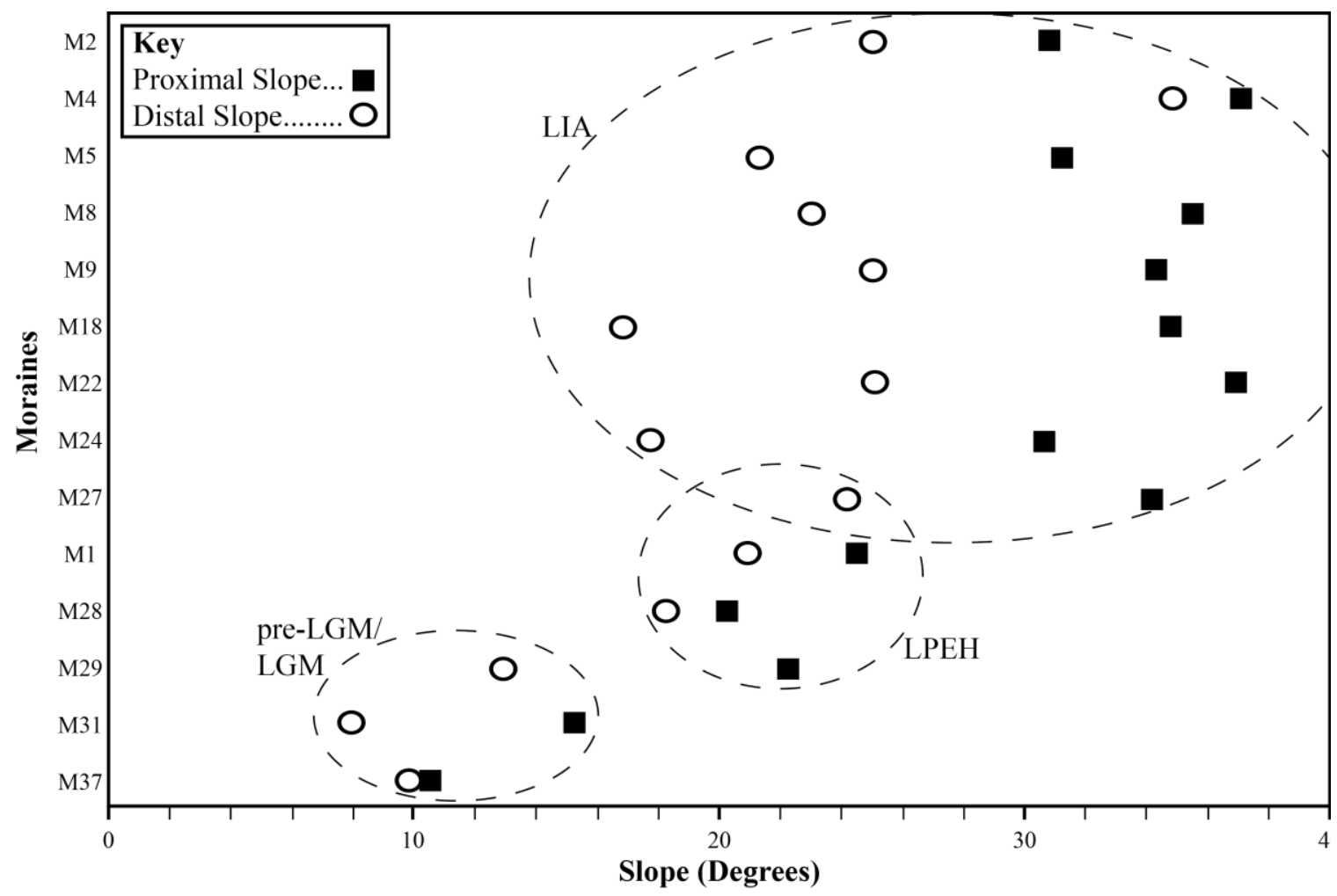

Figure 28: Proximal and distal slope angles for 14 moraines in and near the Goat Rocks Wilderness Area, shown in squares and circles, respectively. The largest cluster of proximal slope points, circled above, represent Little Ice Age (LIA) deposits, the middle cluster represent late Pleistocene (LPEH) deposits, and the lowest cluster represent Last Glacial Maximum (LGM) and pre-LGM deposits. Refer toTable B, Appendix B for key of y-axis. 
Glacial deposits on the southeast side of Rimrock Lake, as indicated by their distance from modern glacial termini, were emplaced when alpine glaciers advanced great distances, probably during the LGM. The depth to the B-horizon and presence of clay films in one of these moraines (M34) suggests relatively old age (Table 2). Proximal slope angles show that moraines near Rimrock Lake are more degraded than others in the Goat Rocks (Figure 28). Moreover, proximal slope angles of the LGM moraines are similar to the McCall type moraines near McCall, Idaho which are proposed to have been deposited at $20 \mathrm{ka} \mathrm{BP}$ (Colman and Pierce, 1986).

Moraines north of Rimrock Lake are suggested to have been deposited during a more extensive glacial advance prior to the LGM. They have subdued crests and are covered with $100 \%$ vegetation and $>50 \mathrm{~cm}$ of soil suggesting relatively old age. Further, a terminal moraine resting north of the lake has a proximal slope angle that closely matches Timber Ridge type moraines near McCall, Idaho estimated to have been emplaced at 140-150 ka BP (Table B, Appendix B) (Colman and Pierce, 1986). 
Table 2: Depth $(\mathrm{cm})$ to weathered horizons in all soil pits in the Goat Rocks. Soil pits are arranged from the shallowest weathered depth to deepest and correlated ash layers and radiocarbon ages and relative stratigraphic positions. Notice that depths to $B$ horizon generally increase with age correlation.

\begin{tabular}{cccc} 
Soil pit & Depth to B & Horizon & Age correlation \\
\hline SP8-082710 & - & - & LIA \\
SP12-091510 & - & - & $?$ \\
SP5-090510 & 2 & $\mathrm{Bw}$ & LPEH \\
SP4-082410 & 4 & $\mathrm{Bw}$ & $>2500-3000 \mathrm{yrs}$ \\
SP16-091610 & 6 & $\mathrm{Bg}$ & $?$ \\
SP9-082610 & 15 & $\mathrm{Bg}$ & $>2500-3000 \mathrm{yrs}$ \\
SP10-082810 & 15 & $4 \mathrm{Bw}$ & $?$ \\
SP11-071310 & 15 & $\mathrm{Bw}$ & LGM? \\
SP3-082510 & 16 & $\mathrm{Bg}$ & LPEH \\
SP2-082610 & 18 & $\mathrm{Bw}$ & LPEH \\
SP7-092410 & 27 & $3 \mathrm{Cox}$ & $>6850 \mathrm{yrs}$ \\
SP13-091510 & 28 & $\mathrm{Cox}$ & $?$ \\
SP14-091610 & 28 & $\mathrm{Bg} 1$ & $?$ \\
SP1-090310 & 30 & $\mathrm{Bw}$ & $13 \mathrm{ka}$ \\
SP6-071410 & 36 & $\mathrm{Btj} 1$ & LGM \\
SP15-091010 & 39 & $4 \mathrm{Bw} 1$ & $?$ \\
& & &
\end{tabular}

The examination of modern glaciers, historic imagery, and moraine deposits allows for reconstruction of the most up-to-date modern and paleo-glacier cover in the Goat Rocks (Figure 29). These glacier areas are used to determine modern and paleoglacier ELAs in Chapter 5. 


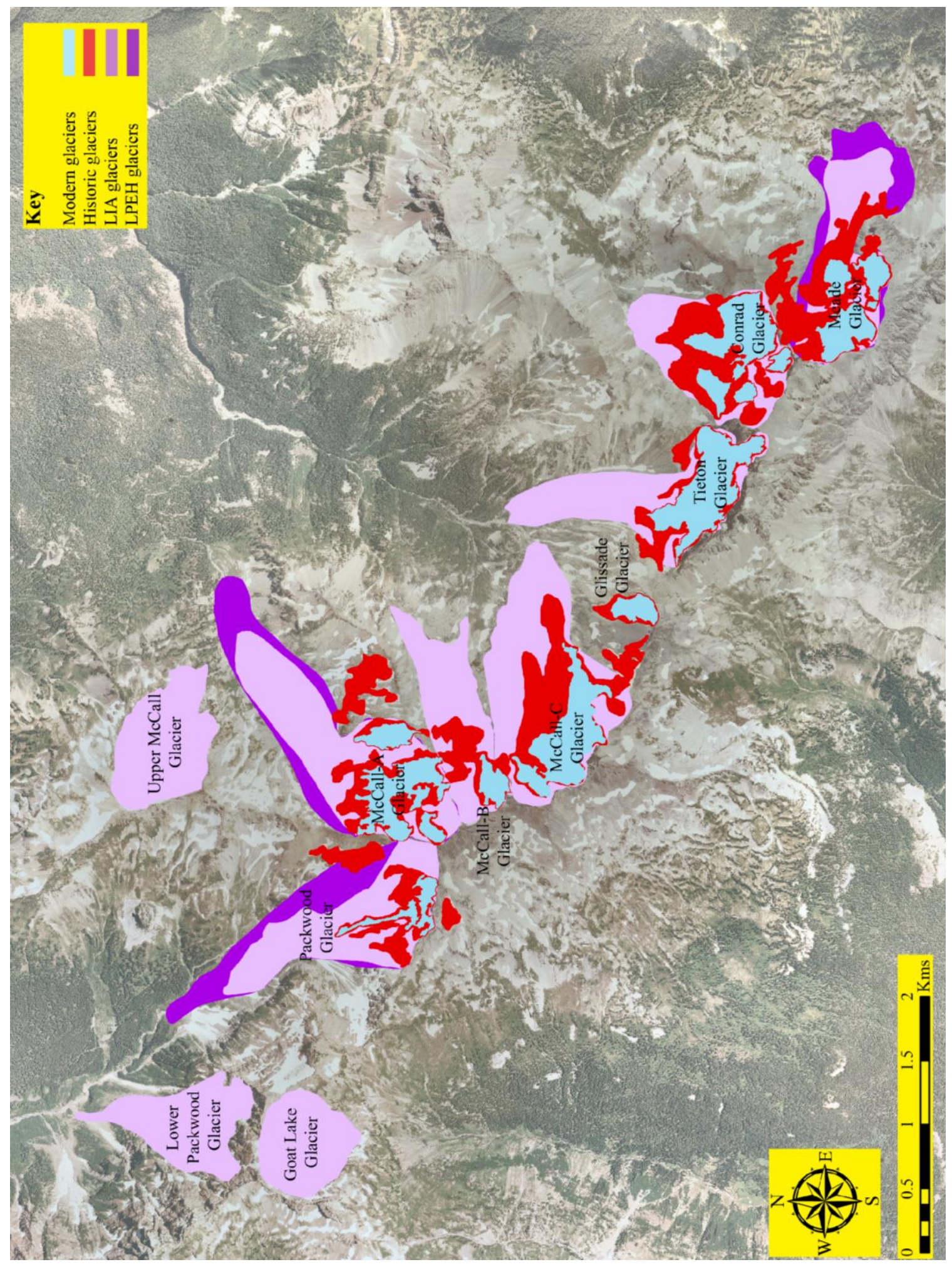

Figure 29: Aerial image with all of the Goat Rocks modern and paleo- glaciers. Historic glacier coverage is from 1955, digitized from USGS topographic maps. 


\section{CHAPTER 5: PALEOCLIMATE RECONSTRUCTION}

Past air temperature and precipitation and timing will be inferred based on my reconstructed glacial extents in the Goat Rocks. The mass balance of a glacier at the equilibrium line is zero. At higher elevation the balance is positive (accumulation zone), at lower elevations the balance is negative (ablation zone) (Leonard and Fountain, 2003). At the equilibrium line the accumulation of snow in winter equals the summer melt. The two climatic variables that index winter snow accumulation and summer melt are winter precipitation and summer air temperature. Leonard (1989) plotted precipitation against air temperature at the equilibrium line for 32 worldwide glaciers. Based on this relationship, while assuming the atmospheric lapse rate is constant over time and Leonard's relationship is also constant over time, the change in ELA from present conditions to past conditions can be used to infer changes in air temperature and precipitation. The current ELA is observed on present-day glaciers, and the ELA of paleo-glaciers can be inferred from its previous geometry.

\subsection{Equilibrium-Line Altitudes (ELAs)}

ELAs for the modern and paleo-glaciers in the Goat Rocks are estimated from three methods that assume equilibrium conditions such that the mass gained in the accumulation zone equals the mass lost in the ablation zone. The first method is the accumulation area ratio (AAR) (Meier and Post, 1962), which assumes that, under equilibrium conditions, the accumulation zone of a glacier accounts for $65 \%$ of the glacier's total area. For alpine glaciers, the AAR actually varies between 0.5 and 0.8 with 
an average value of 0.65 (Paterson, 1994). Heine (1997) and Marcott et al. (2010) reconstructed ELAs on Mt. Rainier and Three Sisters, respectively, by using an AAR value of 0.65 , and I too adopt that ratio.

The second method, Area - Altitude (AA) (Kurowski, 1891), is similar to the AAR method. The AA assumes that the ratio of the mass balance gradient below and above the ELA is constant and equal to one. Although the assumption of linearity is rarely correct, this method gives more reliable ELA estimates that the AAR where a glacier has multiple tributaries (Osmaston, 2005). The method involves calculating the glacier's ELA by subtracting the mean altitude for each contour belt (mean altitude between successive contour lines) from the trial ELA (e.g. the mid-altitude) and multiplying this result by its corresponding contour belt area (area between contour lines) for all the contour belts above and below the trial ELA (Figure 30). 


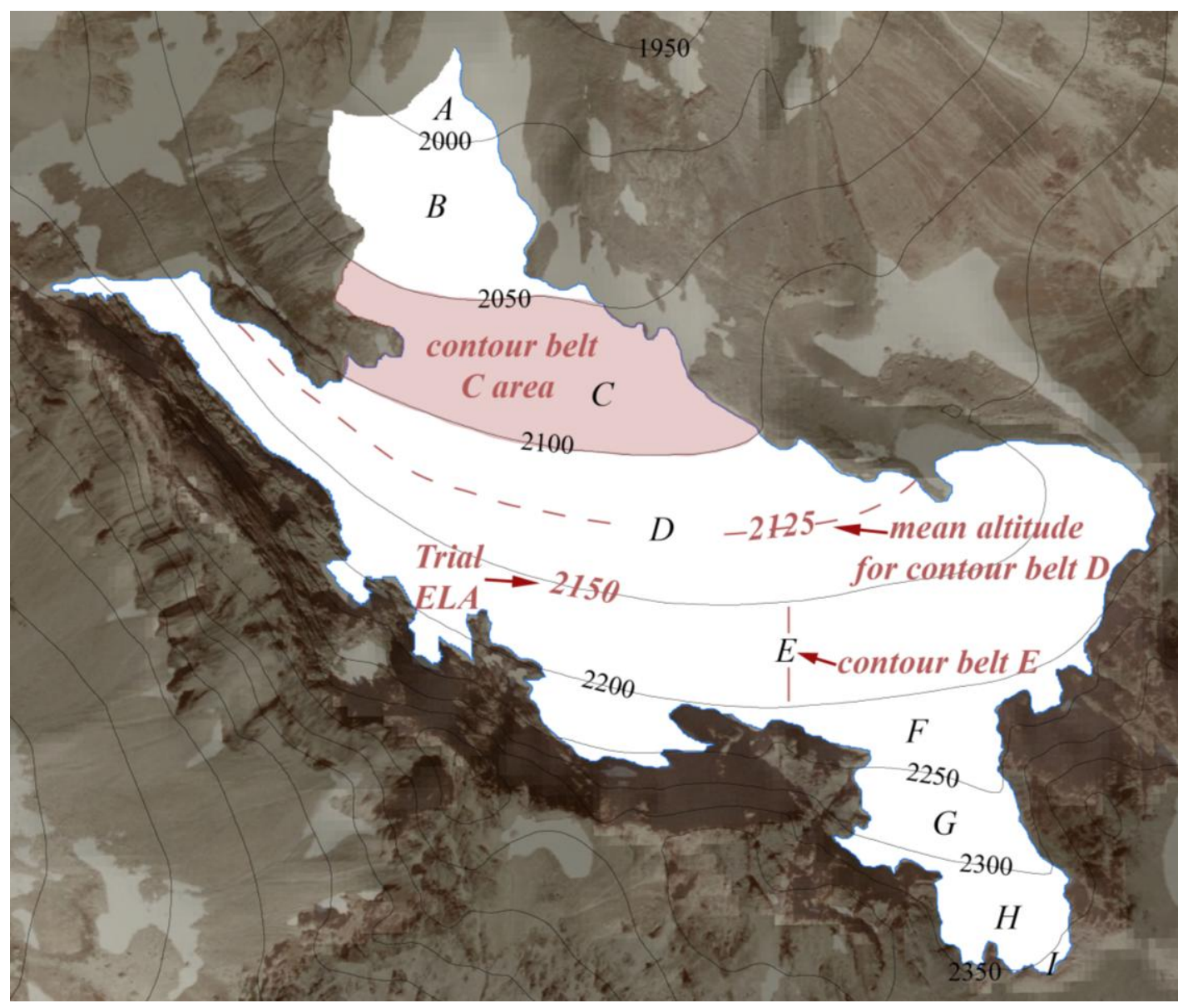

Figure 30: The AA method variables depicted on the Tieton Glacier. The black numbers are contour line elevations and the black letters represent each contour belt (at a $100 \mathrm{~m}$ contour interval) for the Tieton Glacier. The trial ELA is meant to be raised or lowered until Equation 4 produces a zero sum.

The AA ELA is determined when a trial ELA produces a zero sum (m) in

Equation 1:

$$
\frac{\left(\sum_{i=1}^{n}\left((\beta-\delta)^{*} \alpha\right)_{i}\right.}{\sum \alpha_{i}}=0
$$


where $\beta$ is the trial ELA $(\mathrm{m}), \delta$ is the mean altitude for a contour belt $(\mathrm{m}), \alpha$ is the area of a contour belt, and $i$ is the contour belt of $n$ belts. I used a data spreadsheet created by Osmaston (2005) to calculate ELAs with the AA method.

The third method, the balance ratio (BR), is based on the principle that, for equilibrium conditions, the total annual accumulation above the ELA must balance the total annual ablation below the ELA (Benn and Evans, 1998). According to (Furbish and Andrews, 1984):

$$
\frac{b_{n b}}{b_{n c}}=\frac{\bar{z}_{c} A_{c}}{\bar{z}_{b} A_{b}}
$$

where $b_{n b}$ is the net mass-balance gradient in the ablation zone $\left(\mathrm{yr}^{-1}\right), b_{n c}$ is the net massbalance gradient in the accumulation zone $\left(\mathrm{yr}^{-1}\right), \bar{z}_{c}$ is the area-weighted mean altitude of the accumulation zone $(\mathrm{m}), A_{c}$ is the area of the accumulation zone $\left(\mathrm{m}^{2}\right), \bar{z}_{b}$ is the areaweighted mean altitude of the ablation zone $(\mathrm{m})$, and $A_{b}$ is the area of the ablation zone $\left(\mathrm{m}^{2}\right)$. A net-balance ratio, $b_{n b} / b_{n c}$, of 2 is suitable for maritime mid-latitude glaciers (Furbish and Andrews, 1984). The ELA is determined by finding a distribution of a glacier area over its altitude range which is accomplished by reiterating trial ELA calculations until the correct distribution allows the right hand side of Equation 2 to equal the left hand side, or 2. To apply the BR method I used a computer spreadsheet provided by Benn and Gemmell (1997) and constructed another computerized spreadsheet program following instructions by Osmaston (2005). 


\subsubsection{Results}

The results for the AAR, AA, and BR methods are shown in Table 3. The glacier perimeters used to calculate ELAs as well as the resulting average ELAs for all modern to LGM glaciers are displayed in Figure 31-34. The average modern ELA, determined by averaging the averages of each ELA estimation method, is $2160 \pm 72 \mathrm{~m}$. The average ELA for all glaciers increased $158 \pm 61 \mathrm{~m}$ in elevation from the LIA to the average modern position, increased $244 \pm 4 \mathrm{~m}$ in elevation from the LPEH to the average modern position and increased $880 \pm 66 \mathrm{~m}$ from the LGM to the average modern position. Notably, the difference between all the LIA ELAs and the three LPEH ELAs, is $86 \mathrm{~m}$, however, when considering only those glaciers (Packwood, McCall-A, and Meade) that show evidence of both LIA and LPEH stands, the difference in ELA between the two decreases to $36 \mathrm{~m}$. This second estimate evaluates only the glaciers with evidence of glacial stands during the LIA and the LPEH and, thus, more accurately represents the relation between LIA and LPEH ELA positions in the Goat Rocks.

Notably, the ELAs of Meade and McCall-B Glaciers are considerably higher than the average. These discrepancies are probably caused higher headwall elevations and/or glacier orientation. Conversely, the Packwood Glacier has a lower ELA than the average. This is a result of orientation and steep topography which significantly limits direct insolation. Importantly, these discrepancies will influence paleo-climate analysis, albeit, not considerably, since the average of the three is similar to the collective average. 
Table 3: Equilibrium line altitudes (ELAs) for all modern and pre-existing glaciers in the Goat Rocks Wilderness, listed in order of calculations (shown for Meade glacier) from the AAR method (Meier and Post, 1962), the AA method (Kurowski, 1891), the BR method under the Benn \& Gimmel (1997) program $\left(B R^{(B \& G)}\right)$ and the $B R$ method under the Osmaston $(2005)$ program $\left(B R^{(0)}\right)$ for each glacier. The McCieton Glacier is a large LGM glacier that includes the coalescence of all McCall Glaciers, the Glissade Glacier and the Tieton Glacier. ELAs are in meters. > LIA and > LGM represent glaciers that are no longer present. The $1^{\text {st }}, 2^{\text {nd }}, 3^{\text {rd }}$ and last ELA estimates for each glacier are calculated

\begin{tabular}{|c|c|c|c|c|}
\hline Glacier & Modern ELA & LIA ELA & LPEH ELA & LGM ELA \\
\hline$\overline{\text { Meade (AAR) }}$ & 2253 & 1995 & 1968 & $\overline{-}$ \\
\hline$(\mathrm{AA})$ & 2279 & 2106 & 2065 & - \\
\hline$\left(\mathrm{BR}^{\mathrm{B} \& \mathrm{G}}\right)$ & 2271 & 2063 & 2031 & - \\
\hline$\left(\mathrm{BR}^{\mathrm{O}}\right)$ & 2258 & 2057 & 2016 & - \\
\hline \multirow[t]{4}{*}{ Packwood } & 2063 & 1767 & 1754 & - \\
\hline & 2068 & 1881 & 1865 & - \\
\hline & - & 1843 & 1814 & - \\
\hline & 2031 & 1817 & 1797 & - \\
\hline \multirow[t]{4}{*}{ McCall-A } & 2134 & 1924 & 1857 & - \\
\hline & 2160 & 2007 & 1961 & - \\
\hline & 2159 & 1967 & 1916 & - \\
\hline & 2135 & 1947 & 1899 & - \\
\hline \multirow[t]{4}{*}{ McCall-B } & 2244 & 2054 & - & - \\
\hline & 2269 & 2118 & - & - \\
\hline & 2263 & 2094 & - & - \\
\hline & 2249 & 2118 & - & - \\
\hline \multirow[t]{4}{*}{ McCall-C } & 2157 & 1992 & - & - \\
\hline & 2196 & 2056 & - & - \\
\hline & 2199 & 2056 & - & - \\
\hline & 2168 & 2008 & - & - \\
\hline \multirow{4}{*}{ Tieton } & 2122 & 1955 & - & - \\
\hline & 2147 & 2115 & - & - \\
\hline & 2146 & 1991 & - & - \\
\hline & 2121 & 1962 & - & - \\
\hline \multirow[t]{4}{*}{ Conrad } & 2123 & 2058 & - & - \\
\hline & 2154 & 2130 & - & - \\
\hline & 2154 & 2111 & - & - \\
\hline & 2129 & 2091 & - & - \\
\hline \multirow[t]{4}{*}{ Glissade } & 2096 & - & - & - \\
\hline & 2117 & - & - & - \\
\hline & 2117 & - & - & - \\
\hline & 2100 & - & - & - \\
\hline \multirow[t]{4}{*}{ Goat Lake } & > LIA ELA & 1999 & - & - \\
\hline & $>$ LIA ELA & 2032 & - & - \\
\hline & $>$ LIA ELA & 2030 & - & - \\
\hline & $>$ LIA ELA & 2008 & - & - \\
\hline jer Packwood & $>$ LIA ELA & 1630 & - & - \\
\hline
\end{tabular}




\begin{tabular}{ccccc} 
& $>$ LIA ELA & 1693 & - & - \\
& $>$ LIA ELA & 1674 & - & - \\
& $>$ LIA ELA & 1629 & - & - \\
\hline Upper McCall & $>$ LIA ELA & 1938 & - & - \\
& $>$ LIA ELA & 1974 & - & - \\
& $>$ LIA ELA & 1967 & - & - \\
& $>$ LIA ELA & 1943 & - & - \\
\hline McCieton & - & - & - & 1335 \\
& - & - & - & 1339 \\
& - & - & - & 1216 \\
AAR average & 2149 & 1931 & 1860 & 1230 \\
Standard deviation & 67 & 134 & 107 & - \\
\hline AA average & 2174 & 2011 & 1964 & - \\
Standard deviation & 72 & 136 & 100 & - \\
\hline BR $(B \& G)$ average & 2181 & 1980 & 1920 & - \\
Standard deviation & 58 & 133 & 109 & - \\
\hline BR $(O)$ average & 2149 & 1958 & 1904 & - \\
Standard deviation & 76 & 144 & 110 & -
\end{tabular}

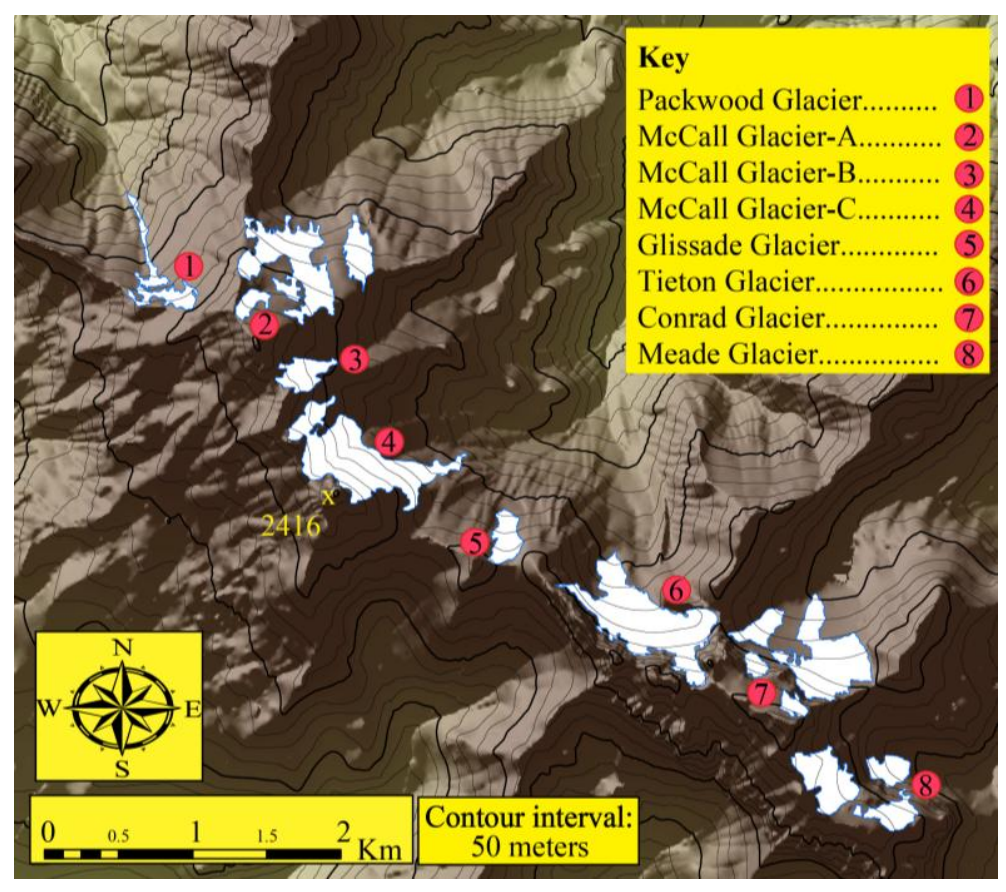

Figure 31: Modern glacier perimeters used to calculate ELAs in the Goat Rocks. 


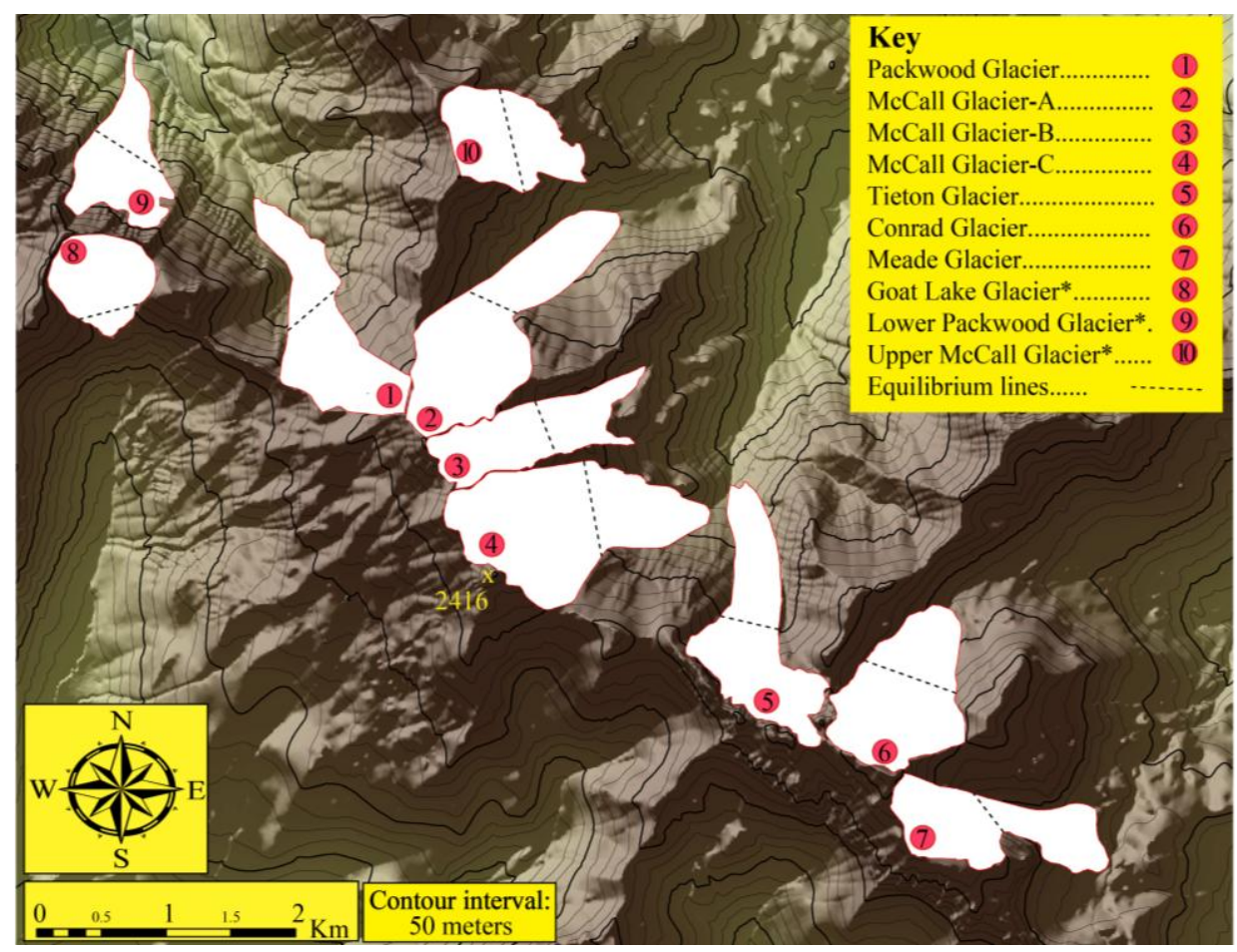

Figure 32: LIA glacier perimeters used to calculate ELAs (also shown) in the Goat Rocks.

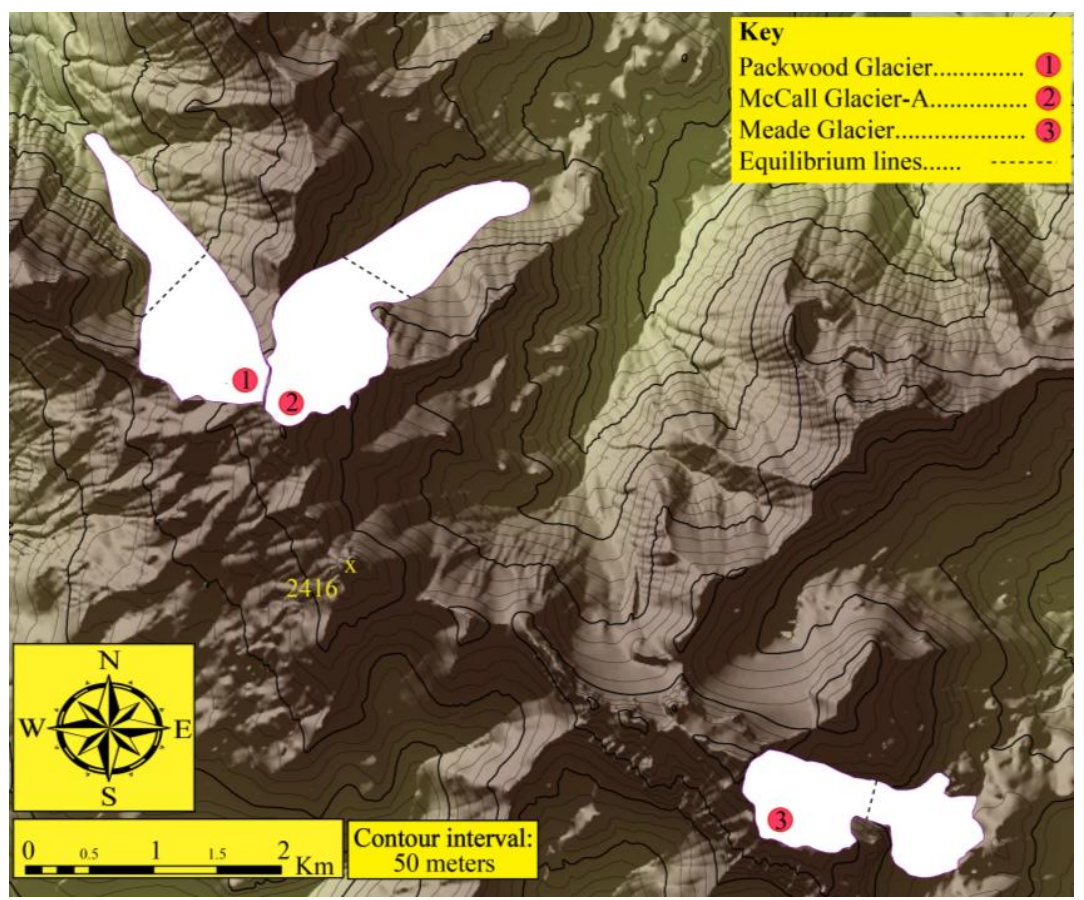

Figure 33: LPEH glacier perimeters used to calculate ELAs (also shown) in the Goat Rocks. While other glaciers certainly existed during this time they have been left off this figure because no evidence was located to recreate them. 


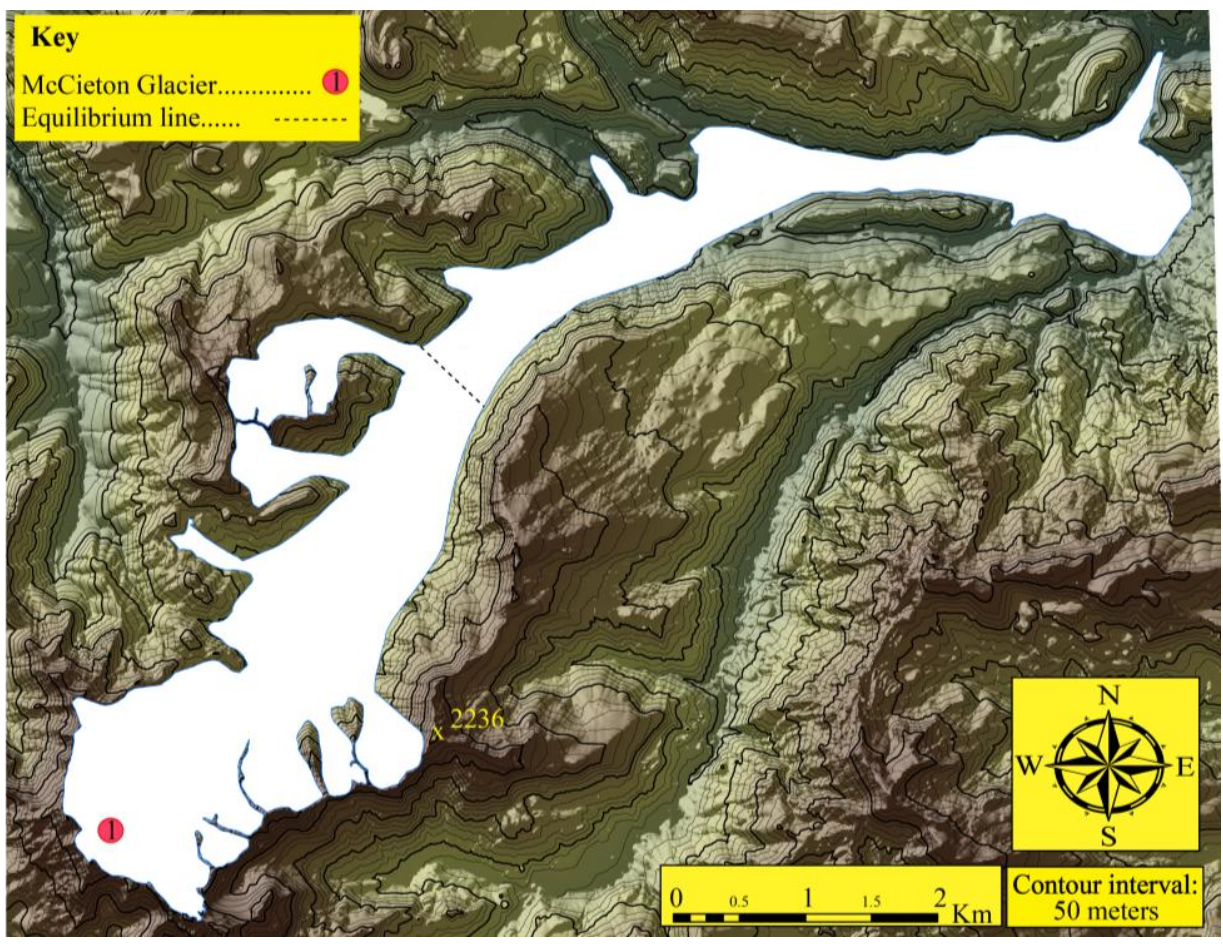

Figure 34: LGM glacier perimeter used to calculate the LGM ELA (also shown) in the Goat Rocks. While other glaciers certainly existed during this time they have been left off this figure because no evidence was located to recreate them. The source area is where the McCall-B, McCall-C, Glissade, and Tieton Glacier's currently reside.

The BR method using Osmaston's program $\left(\mathrm{BR}^{\circ}\right)$ returned ELA estimates that were regularly within $20 \mathrm{~m}$ of the BR ELA estimates using Benn and Gimmel's program $\left(\mathrm{BR}^{\mathrm{B} \& \mathrm{G}}\right)$ and often close to AAR ELA estimates. Typically, the AA and AAR methods calculated the highest and lowest ELA estimates for each glacier, respectively. However, the $\mathrm{BR}^{\circ}$ and $\mathrm{BR}^{\mathrm{B} \& \mathrm{G}}$ ELA estimates are $~ 100 \mathrm{~m}$ lower than the AA and AAR ELA estimates for the LGM McCieton Glacier. These differences are considerable and likely due to LGM glacier's geometry, which is unlike the small alpine glacier geometries of the modern, LIA, and LPEH glaciers. Nevertheless, the $\mathrm{BR}^{\circ}$ method produced ELA estimates that varied within the range of all ELA method estimates and appears to be very 
useful for determining ELAs for glaciers that have a complex shape (Furbish and Andrews, 1984), such as those in the Goat Rocks. Therefore, I have decided to use the $\mathrm{BR}^{\mathrm{o}}$ for paleo-climate reconstructions.

\subsection{Modern Climate at Paleo-glacier ELAs}

To infer changes in summer air temperature and winter precipitation from the date of past glacier extents compared to modern climate, I compare the paleo-climate at the elevation of the paleo-ELAs against the current climate at those elevations. The current climate is estimated from SNOTEL sites. SNOTEL (snow telemetry) is a program of the United States Department of Agriculture -Natural Resources Conservation Service that monitors snowpack and other meteorological data needed to produce water supply forecasts in the western United States. Summer (June-August) air temperatures from seven SNOTEL sites and the highest monthly mean snow accumulation (April or May) from four SNOTEL sites were determined (Table 4). All SNOTEL data represent the period from 1971-2000 (NRCS, 2011). Since many variables influence temperature and snow accumulation, selected SNOTEL sites were near the Goat Rocks and representative of the elevations and orographic setting (Cascade Crest) found there (Figure 35). Since a limited number of SNOTEL sites are located in close proximity to the Goat Rocks only four SNOTEL sites for snow accumulation and seven SNOTEL sites for summer temperature were used. 
Table 4: Modern (1971-2000) mean summer (June-August) temperatures and highest monthly mean snow accumulation (April or May) at SNOTEL sites near the Goat Rocks Wilderness, WA. Cm weq is $\mathrm{cm}$ of water equivalent. Lat, Long is the latitude and longitude in degrees and minutes.

\begin{tabular}{|c|c|c|c|c|}
\hline SNOTEL Site & $\frac{\text { Location }}{\text { (Lat, Long) }}$ & $\frac{\text { Elevation }}{\underline{(\mathbf{m})}}$ & $\frac{\text { Temperature }}{\underline{\left({ }^{\circ} \mathrm{C}\right)}}$ & $\frac{\text { Snow accum. }}{\text { (cm weq.) }}$ \\
\hline Packwood & $46^{\circ} 37^{\prime}, 121^{\circ}-40^{\prime}$ & 323 & 17.2 & \\
\hline Tieton Intake & $46^{\circ} 40^{\prime}, 121^{\circ}=0^{\prime}$ & 695 & 15.2 & \\
\hline Rimrock Lake Dam & $46^{\circ} 39^{\prime}, 121^{\circ} 8^{\prime}$ & 833 & 15.6 & \\
\hline Longmire Rainier NPS & $46^{\circ} 45^{\prime}, 121^{\circ}-49^{\prime}$ & 842 & 14.4 & \\
\hline Stampede Pass WSCMO & $47^{\circ} 17^{\prime}, 121^{\circ} 20^{\prime}$ & 1206 & 11.9 & \\
\hline Stevens Pass & $47^{\circ} 44^{\prime}, 121^{\circ} 5^{\prime}$ & 1241 & 11.5 & \\
\hline Rainier Paradise Ranger & $46^{\circ} 47^{\prime}, 121^{\circ} 44^{\prime}$ & 1654 & 9.6 & \\
\hline White Pass (East side) & $46^{\circ} 38^{\prime}, 121^{\circ} 23^{\prime}$ & 1353 & & 60.7 \\
\hline Potato Hill & $46^{\circ} 38^{\prime}, 121^{\circ}=23^{\prime}$ & 1375 & & 64.3 \\
\hline Bumping Ridge & $46^{\circ} 49^{\prime}, 121^{\circ}=20^{\prime}$ & 1405 & & 72.9 \\
\hline Pigtail Peak & $46^{\circ} 21^{\prime}, 121^{\circ} 31^{\prime}$ & 1768 & & 143.5 \\
\hline
\end{tabular}

From the SNOTEL data the summer air temperature and snow accumulation at the modern ELA are extrapolated from linear elevation gradients of each (Figure 36). For snow accumulation the gradient is $19.9 \mathrm{~cm}$ weq / $100 \mathrm{~m}$, with a statistically significant $\mathrm{r}^{2}$ is $1.00, \mathrm{p}<0.01$. The summer air temperature gradient is $-0.6{ }^{\circ} \mathrm{C} / 100 \mathrm{~m}$, with a statistically significant $\mathrm{r}^{2}$ is $0.96, \mathrm{p}<0.01$. The results are summarized in Table 5 . 

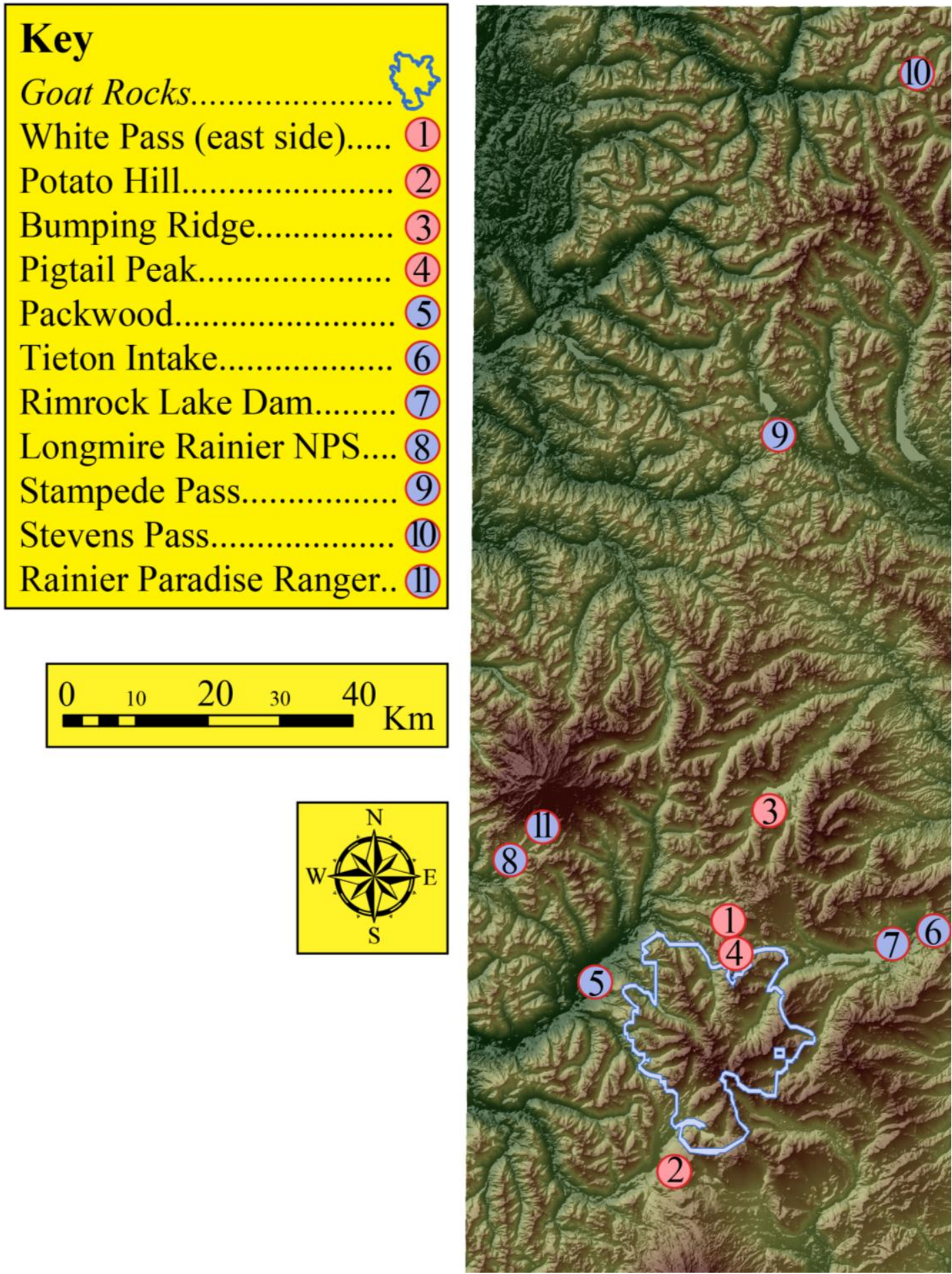

Figure 35: SNOTEL sites near the Goat Rocks Wilderness. The red and blue circles represent SNOTEL sites that were used for highest monthly mean snow accumulation and mean summer temperatures, respectively. 

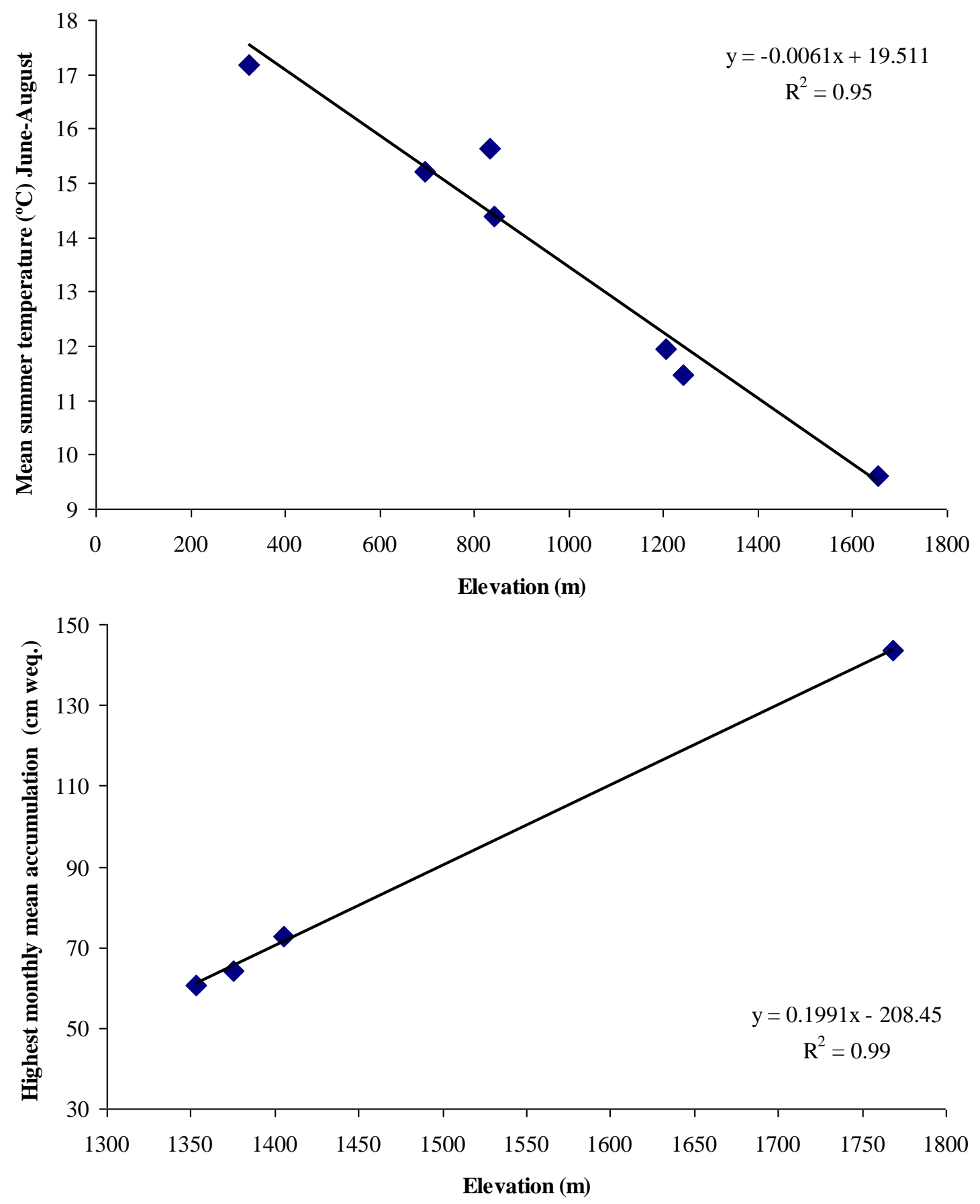

Figure 36: Linear regression analysis lines for summer temperature versus elevation at seven SNOTEL sites (top graph) and for snow accumulation ( $\mathrm{cm}$ of water equivalent) versus elevation for four SNOTEL sites (bottom graph) in close proximity to the Goat Rocks Wilderness. 
Following Leonard's (1989) approach, paleo-climate estimates are made by comparing ELA climate at modern ELAs to ELA climate at paleo-ELAs, assuming that ELA climatic conditions have not varied over time. Paleo-climate estimates consider only ELA estimates that were calculated using Osmaston (2005) techniques. By extrapolating the precipitation and temperature gradients to the average ELA for modern glaciers in the Goat Rocks, the average modern winter accumulation and mean summer air temperature was estimated at $219.4 \mathrm{~cm}$ weq and $6.4^{\circ} \mathrm{C}$, respectively (Table 5). The climate conditions at average ELA for modern glaciers in the Goat Rocks fit within the envelope of Leonard's distribution (Figure 37). The one estimated ELA condition for modern glaciers in the Goat Rocks that fall outside Leonard's envelope is Packwood Glacier. Either the climate envelope doesn't span the range of conditions at modern ELAs or the climate calculations for Packwood Glacier contain error. The former assumption is reasonable because the Packwood Glacier is positioned in a location of deep shading and receives little direct insolation. Notably, not all of Leonard's data points fall within the envelope.

Modern climate conditions at paleo-ELAs were determined by extrapolating precipitation and temperature gradients to the average paleo-ELAs (Table 5). Table 6 contains climate adjustments required to match paleo-ELA climate conditions to modern ELAs and the modern climate envelope. 


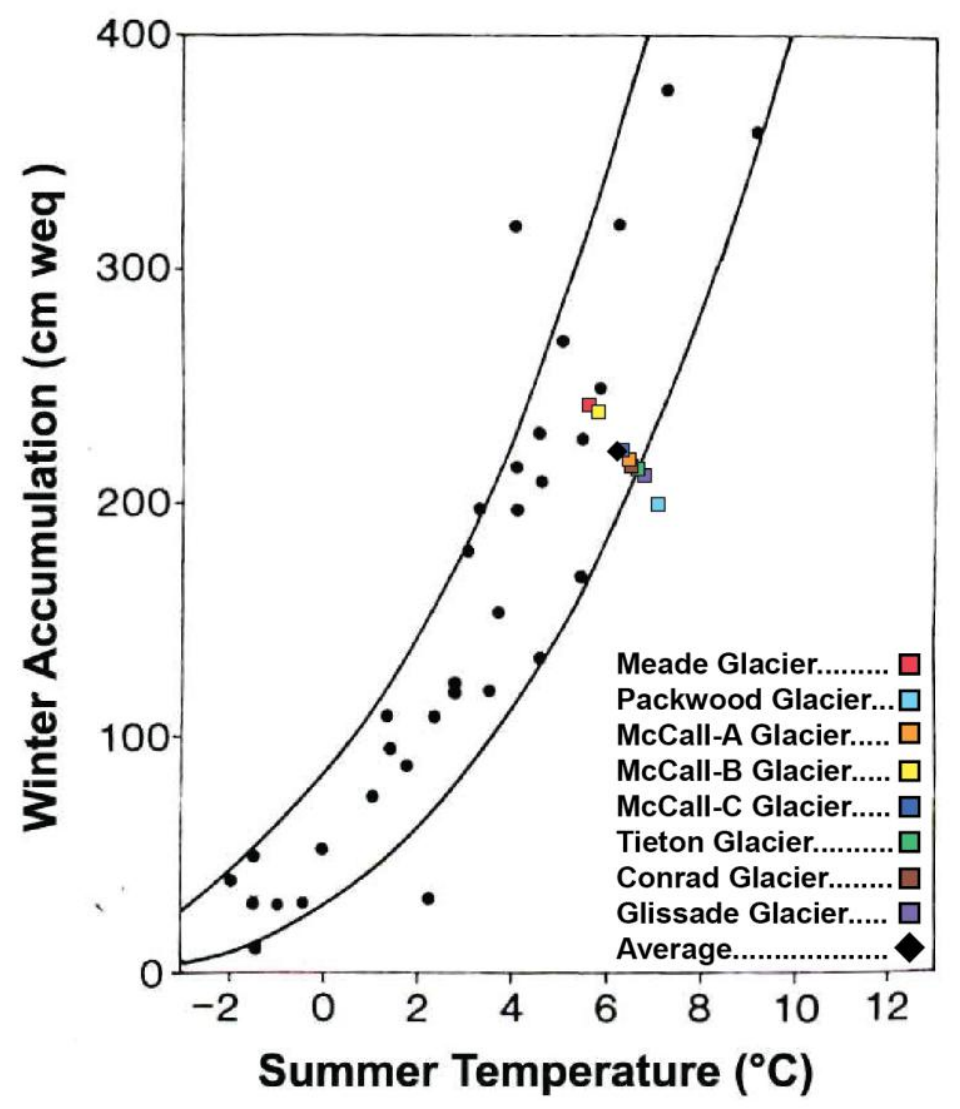

Figure 37: Modern average winter snow accumulation versus summer (June-August) average temperatures for modern ELAs at a worldwide distribution of 32 glaciers (Leonard, 1989) and at the modern ELAs for Goat Rocks glaciers (using BR method calculation techniques by Osmaston 2005). The black circles and represent the 32 worldwide glaciers. Weq is snow water equivalent or the amount of water within a snowpack.

Paleo-glacier ELAs with modern climate estimates that fell nearest to and furthest from the modern climate envelope in Figure 37 were used to calculate the minimum and maximum adjustments, respectively, required for climate at the paleo-ELAs to fall within the climate envelope (Figure 38 and Table 6). These minimum and maximum adjustments, in effect, represent paleo-climate range at paleo-ELA. 
Table 5: Interpolated and extrapolated modern climate data for modern and past ELAs, using BR method calculation techniques by Osmaston (2005), in the Goat Rocks Wilderness.

\begin{tabular}{|c|c|c|c|c|}
\hline & Glacier & $\begin{array}{c}\text { ELA } \\
\underline{(\mathbf{m})} \\
\end{array}$ & $\begin{array}{c}\begin{array}{c}\text { Winter } \\
\text { accumulation } \\
\text { (cm weq.) }\end{array} \\
\end{array}$ & $\begin{array}{c}\text { Summer } \\
\text { Temperature } \\
\left({ }^{\circ} \mathrm{C}\right) \\
\end{array}$ \\
\hline \multirow[t]{10}{*}{ Modern } & Meade & 2258 & 241 & 5.7 \\
\hline & Packwood & 2031 & 196 & 7.1 \\
\hline & McCall-A & 2135 & 217 & 6.5 \\
\hline & McCall-B & 2249 & 239 & 5.8 \\
\hline & McCall-C & 2168 & 223 & 6.3 \\
\hline & Tieton & 2121 & 214 & 6.6 \\
\hline & Conrad & 2129 & 215 & 6.5 \\
\hline & Glissade & 2100 & 210 & 6.7 \\
\hline & Average & 2149 & 219 & 6.4 \\
\hline & Standard Dev. & 76 & 15 & 0.5 \\
\hline \multirow[t]{11}{*}{ LIA } & Meade & 2057 & 201 & 7.0 \\
\hline & Packwood & 1817 & 153 & 8.4 \\
\hline & McCall-A & 1947 & 179 & 7.6 \\
\hline & McCall-B & 2118 & 213 & 6.6 \\
\hline & McCall-C & 2008 & 191 & 7.3 \\
\hline & Tieton & 1962 & 182 & 7.5 \\
\hline & Conrad & 2091 & 208 & 6.8 \\
\hline & Goat Lake & 2008 & 191 & 7.3 \\
\hline & Upper McCall & 1943 & 178 & 7.7 \\
\hline & Average & 1995 & 189 & 7.3 \\
\hline & Standard Dev. & 70 & 14 & 0.4 \\
\hline \multirow[t]{5}{*}{ LPEH } & Meade & 2016 & 193 & 7.2 \\
\hline & Packwood & 1797 & 149 & 8.5 \\
\hline & McCall-A & 1899 & 170 & 7.9 \\
\hline & Average & 1904 & 171 & 7.9 \\
\hline & Standard Dev. & 110 & 22 & 0.7 \\
\hline LGM & McCieton & 1230 & 36 & 12.0 \\
\hline
\end{tabular}


Table 6: Climate adjustments using Table 5 and Leonard (1989) required to match paleo-ELA climate conditions to modern ELA or modern climate envelope climate conditions.

\begin{tabular}{|c|c|c|c|c|c|}
\hline & $\begin{array}{c}\text { Climate } \\
\text { adjustment of }\end{array}$ & $\begin{array}{c}\text { Climate } \\
\text { adjusted to }\end{array}$ & $\begin{array}{c}\text { Adjustment } \\
\text { range }\end{array}$ & $\begin{array}{c}\Delta \text { in winter } \\
\text { accumulation } \\
\text { (cm weq.) }\end{array}$ & $\begin{array}{c}\Delta \text { in Summer } \\
\text { Temp. } \\
\left({ }^{\circ} \mathrm{C}\right)\end{array}$ \\
\hline \multirow[t]{4}{*}{ LIA } & Conrad ELA & Conrad modern ELA & minimum & 8 & -0.2 \\
\hline & Packwood ELA & Packwood modern ELA & maximum & 43 & -1.3 \\
\hline & Packwood ELA & modern climate envelope & maximum & 151 & -3.2 \\
\hline & average ELA & modern climate envelope & average & 57 & -1.2 \\
\hline \multirow[t]{5}{*}{ LPEH } & Packwood ELA & Packwood modern ELA & minimum & 47 & -1.4 \\
\hline & Meade ELA & Meade modern ELA & maximum & 48 & -1.5 \\
\hline & Meade ELA & modern climate envelope & minimum & 46 & -1.0 \\
\hline & Packwood ELA & modern climate envelope & maximum & 162 & -3.5 \\
\hline & average ELA & modern climate envelope & average & 104 & -2.2 \\
\hline LGM & McCieton ELA & average modern ELA & average & 183 & -5.6 \\
\hline
\end{tabular}

The left and right slopes of the climate envelope in Figure 37 can be defined by Equations 3 and 4 (Kotlayakov and Frenke, 1982), respectively:

$$
\begin{aligned}
& A=1.33\left(T_{v i-v i i i}+9.66\right)^{2.85} \\
& A=1.33\left(T_{v i-v i i i}+6.66\right)^{2.85}
\end{aligned}
$$

where $A$ is winter accumulation in millimeters of water equivalent (weq.) and $T_{v i-v i i}$ is the mean June through August temperature defined at the ELA. Since the estimated modern climates for the paleo-ELAs fall below the envelope, only Equation 4 was required to calculate the climate adjustments needed to fall within the envelope (Figure $38)$. 

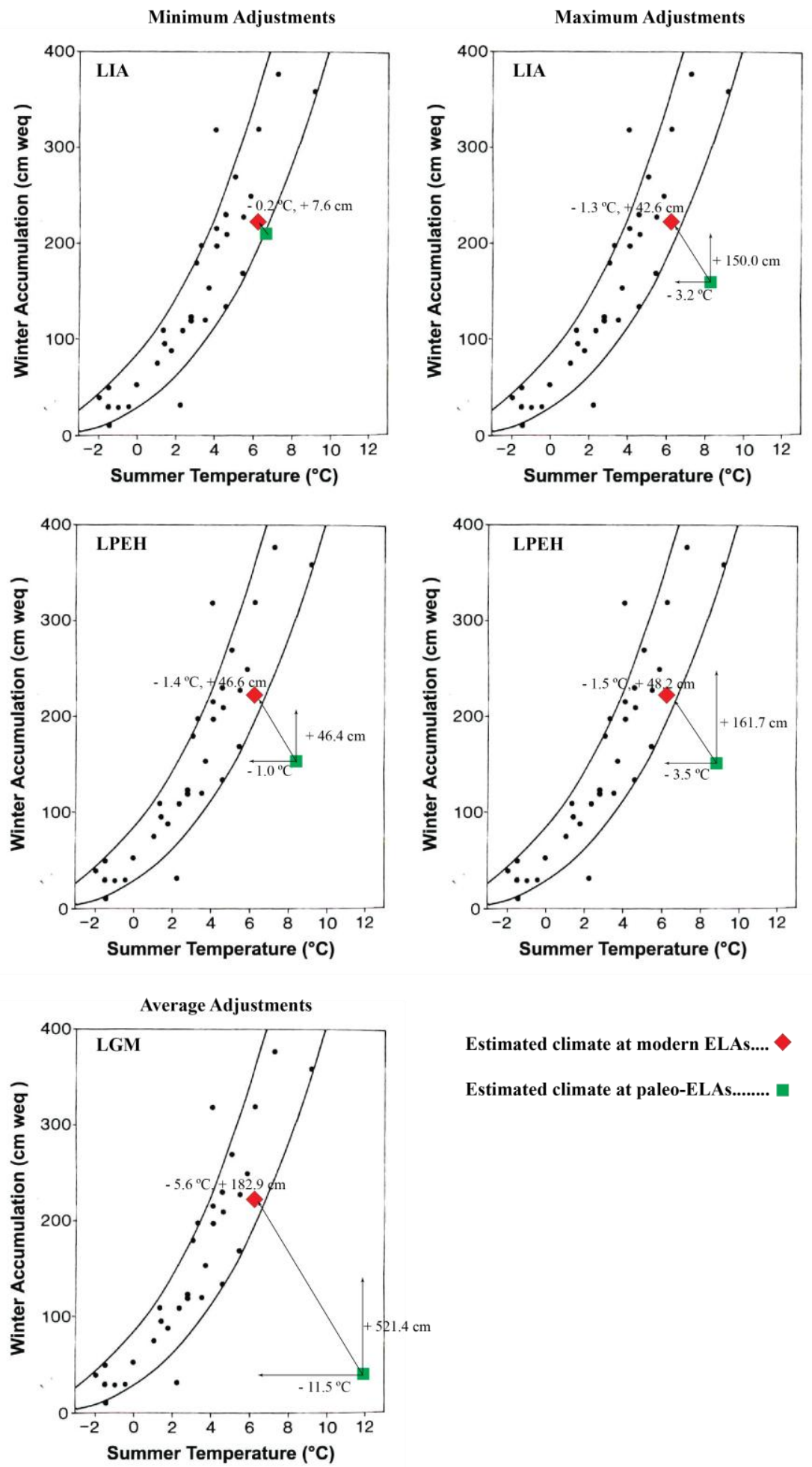

Estimated climate at modern ELAs....

Estimated climate at paleo-ELAs........

Figure 38: Estimated climate conditions at modern and past ELAs and the minimum and maximum temperature depressions and winter accumulation increases required to shift paleo-ELAs into modern climate conditions. The black circles in each graph represent the 32 world wide glaciers used to create the modern climate envelope. 


\section{CHAPTER 6: DISCUSSION \& CONCLUSIONS}

\subsection{Goat Rocks glacial deposits and their age correlations to other western North American glacial deposits}

\subsubsection{The LIA}

The most recent glacial advances in the Goat Rocks and other regions in western North America occurred during the late-Neoglacial, an 'epoch of renewed but moderate glaciation which followed the warmest part of the Holocene' (Matthes, 1939). Many researchers have classified all glacier advances during the last $1.0 \mathrm{ka} \mathrm{BP}$ as belonging to LIA. LIA glacial advances began after the medieval warm period lasted $~ 1200$ to $800 \mathrm{yrs}$. BP. Grove (1988) dates the LIA at 100 to 750 yrs. BP. In the Coast Mountains of southwestern Canada, glaciers began to advance $\sim 1 \mathrm{ka}$ BP, defining the beginning of the LIA there (Davis et al., 2009; Osborn et al., 2007). Glaciers on Mt. Baker and in the central Sierra Nevada reached their maximum positions at $\sim 480$ and 650 yrs. BP, respectively (Davis et al., 2007; Clark and Gillespie, 1997). In the Spearhead and Fitzsimmons ranges of British Columbia and the Three Sisters of Oregon maximum Neoglacial positions occurred during the early $18^{\text {th }}$ to mid $19^{\text {th }}$ centuries (Osborn et al., 2007; O’Connor et al, 2001).

Locally, near the Goat Rocks Wilderness, glaciers on Mt. Rainier advanced at least three times since AD 1450 (Crandell and Miller, 1974; O’Neal, 2005). During this period, known as the Garda Stade, glaciers on Mt. Rainier reached maximum extents 
250 m below glacier termini of the 1960's (Crandell and Miller, 1974). It appears that half of the glaciers reached maximum positions during the mid AD 1800's (Crandell and Miller, 1974).

In the Goat Rocks, LIA glacial deposits were found and mapped for three extinct glaciers (Lower Packwood, Upper McCall, and Goat Lake) and all modern glaciers (Packwood, McCall A,B, and C, Tieton, Conrad, and Meade) except for Glissade Glacier. LIA moraines contain very little, if any, vegetation cover, less than $5 \mathrm{~cm}$ soil, and minimally eroded crests. These characteristics are similar to other LIA moraines found in Washington on Mt. Rainier and Mt. Adams, and in Oregon on the Three Sisters (O'Neal and Schoenenberger, 2003; Mahaney et al., 1981; and Marcott, 2005). Proximal moraine slopes averaged $33.7^{\circ}$ which correlates well with the sharp steeply sloped moraine $\left(34.5^{\circ}\right)$ used to start a model for moraine degradation in the western United States by Putkonen and O’Neal (2006).

Lichenometry studies suggest that the LIA moraines were formed between 75 and 139 years BP (AD 1934-1870). Lichen populations on moraines deposited by the LIA McCall Glacier-C, the LIA lower Packwood Glacier and the LIA Packwood Glacier best represent the time of LIA culmination, between 110 and 139 years BP (AD 1870-1899), in the Goat Rocks, because they are found at elevations (1300-1700 m) that match those used to create the Cascadia growth curve. Lichen measurements that I made at higher elevations $1800 \mathrm{~m}$ for the remaining glaciers (McCall Glaciers, Conrad Glacier, and Meade Glacier), where snow coverage lasts nine to ten months of a year, probably do not adequately satisfy the assumptions of the growth curve and are used as minimum ages. 
By comparison, the Nisqually Glacier on Mt. Rainier reached its maximum LIA extents in 1857, 164 years BP, according to lichenometric dating (Porter, 1981b). On Mt. Adams, ground-based photographs from 1904 can be used to represent a minimum date for LIA moraine formation (Sitts et al., 2010). For the Eliot Glacier on Mt. Hood, spatial change data since 1901 has shown glacial retreat and can be used to represent a minimum date for LIA moraine formation (Jackson and Fountain, 2007). Glaciers on the Three Sisters in Oregon reached their maximum LIA extents within the last 300 years, possibly culminating near AD 1850 (Marcott et al., 2009) (Figure 39).

\subsubsection{The pre-LIA through pre-YD}

While no convincing global pattern, such as that of the Younger Dryas, indicates a distinct cooling period during the Neoglacial, multiple glacial advances did occur in western North America during that time (Porter, 1981a; Konrad and Clark, 1998). Informally, the Neoglacial period refers to the interval when glaciers in the Northern Hemisphere expanded from their minimal extents of the early to mid-Holocene (Menounos et al., 2009). Porter (1981a) groups Neoglacial advances into four time periods, at 5.3 to $5.0 \mathrm{ka} \mathrm{BP}, 3.0$ to $2.8 \mathrm{ka} \mathrm{BP}, 1.2$ to $1.0 \mathrm{ka} \mathrm{BP}$, and during the Little Ice Age (LIA), 300 to $100 \mathrm{yr}$ BP. A more recent synopsis by Menounos et al. (2009) classifies advances as early Neoglacial (7.5 to 5.0 ka BP), early-middle Neoglacial (5.0 $3.5 \mathrm{ka} \mathrm{BP}$ ), middle-late Neoglacial (3.5 to $1.0 \mathrm{ka} \mathrm{BP}$ ), and late Neoglacial (1.0 ka BP to present). 


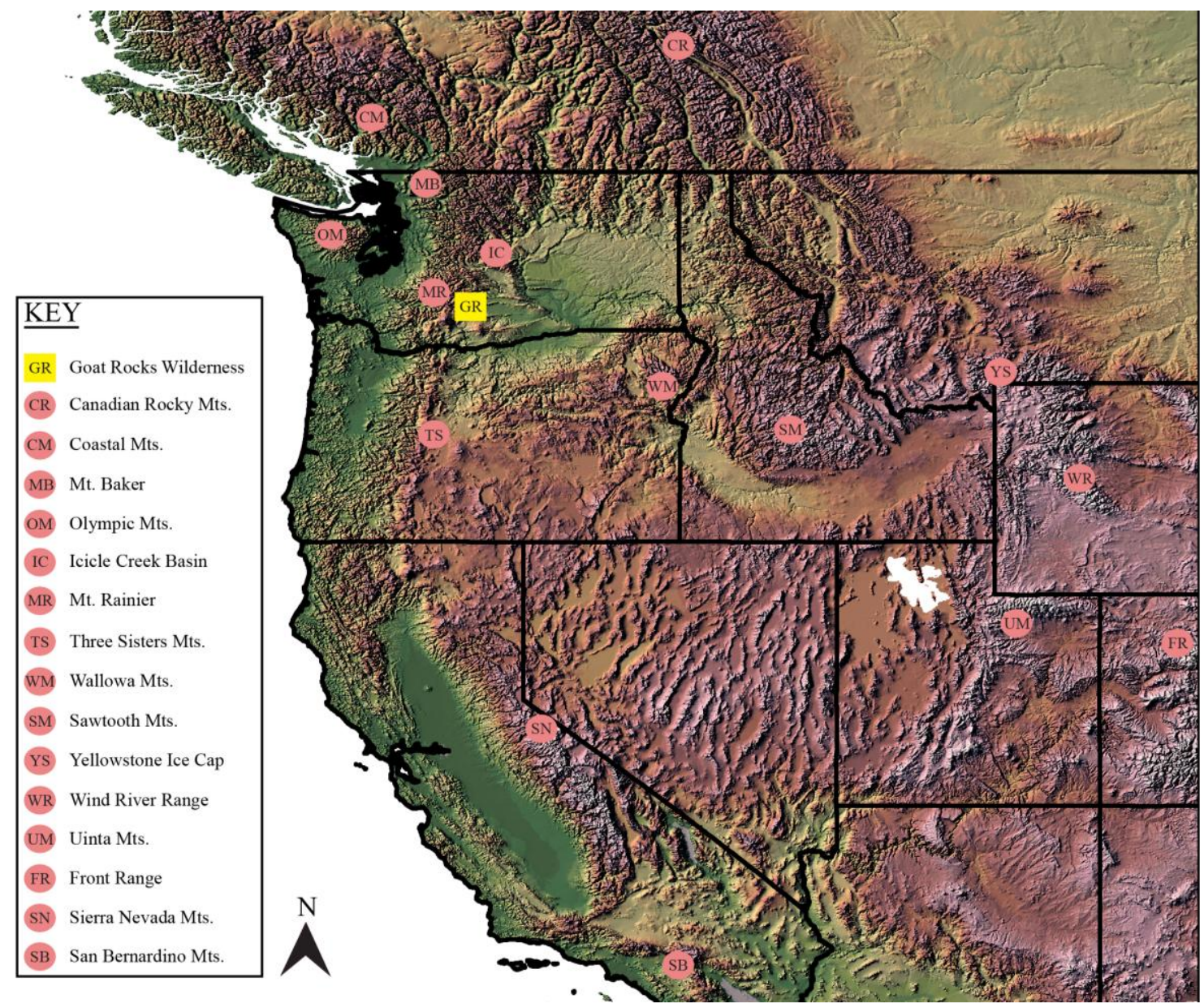

Figure 39: Research locations concerning temporal and spatial aspects of alpine glacier systems in the western United States and southwestern Canada. The yellow square represents the study area for this thesis. Glacial advance/standstill dates are in italic. * represent ${ }^{14} \mathrm{C}$ ages. All other dates are years before present as determined by calibration, $36^{\mathrm{Cl}}$ ages, $10^{\mathrm{Be}}$ ages, or $3^{\mathrm{He}}$ ages.

In southwestern Canada, several glacial advances throughout the Neoglacial have been recognized, through ${ }^{14} \mathrm{C}$ dating, in the Coastal Mountains and Canadian Rockies (Luckman et al., 1993; Osborn et al., 2007; Menounos et al., 2009) (Figure 39, Figure 40). Conversely, while latest Neoglacial (LIA) deposits are common in the western United States, early-middle to middle-late Neoglacial deposits are rare. 
This suggests that glaciers in the western United States did not advance during the pre-late Neoglacial or that, more likely, glacial advances during the late Neoglacial erased earlier glacial deposits; as many regions appear to have experienced their most extensive Neoglacial advance during the last $1.0 \mathrm{ka}$ BP (Clark and Gillespie, 1997). Nevertheless, evidence for glacial advances in the western United States during the earlymiddle and middle-late Neoglacial appear in the Sierra Nevada, at Mt. Baker in the Washington Cascades, in the Three Sisters of the Oregon Cascades, and on Mt. Rainier (Konrad and Clark, 1998; Davis et al., 2007; Marcott, 2005; Crandell and Miller, 1974). Ash layers in Goat Rocks moraines suggest that LPEH deposits may have been emplaced during the pre-late Neoglacial but moraine morphometric characteristics suggest they may be older.

As expressed in a number of terrestrial and marine records in the North Atlantic region, the 8.2 ka BP event was a cold period lasting from 8.4 to 8.0 ka BP (Clark et al., 2001) (Figure 40). This prominent event, approximately half the amplitude of the Younger Dryas, affected regions well beyond the North Atlantic (Alley et al., 1997; Alley and Ágústsdóttir, 2005). Detrital wood collected from glacial forefields in the Coastal Mountains of southwestern British Columbia contain clear evidence connecting glacier stands of western North America to the $8.2 \mathrm{ka} \mathrm{BP}$ event by yielding calibrated ${ }^{14} \mathrm{C}$ ages of 8.63 to $8.02 \mathrm{ka} \mathrm{BP}$ (Menounos et al., 2004). A lake core collected in the same region contained evidence suggesting a minor glacier advance between 8.59 and $7.51 \mathrm{ka}$ BP (Menounos et al., 2004). Other less convincing evidence comes from ${ }^{10} \mathrm{Be}$ dates on moraines in the San Bernardino Mountains that overlap the $8.2 \mathrm{ka}$ BP cooling but might 
also include younger deposits of the Neoglacial (Owen et al., 2003). No evidence in the Goat Rocks was able to confine glacial advances to the $8.2 \mathrm{ka} \mathrm{BP}$ event.

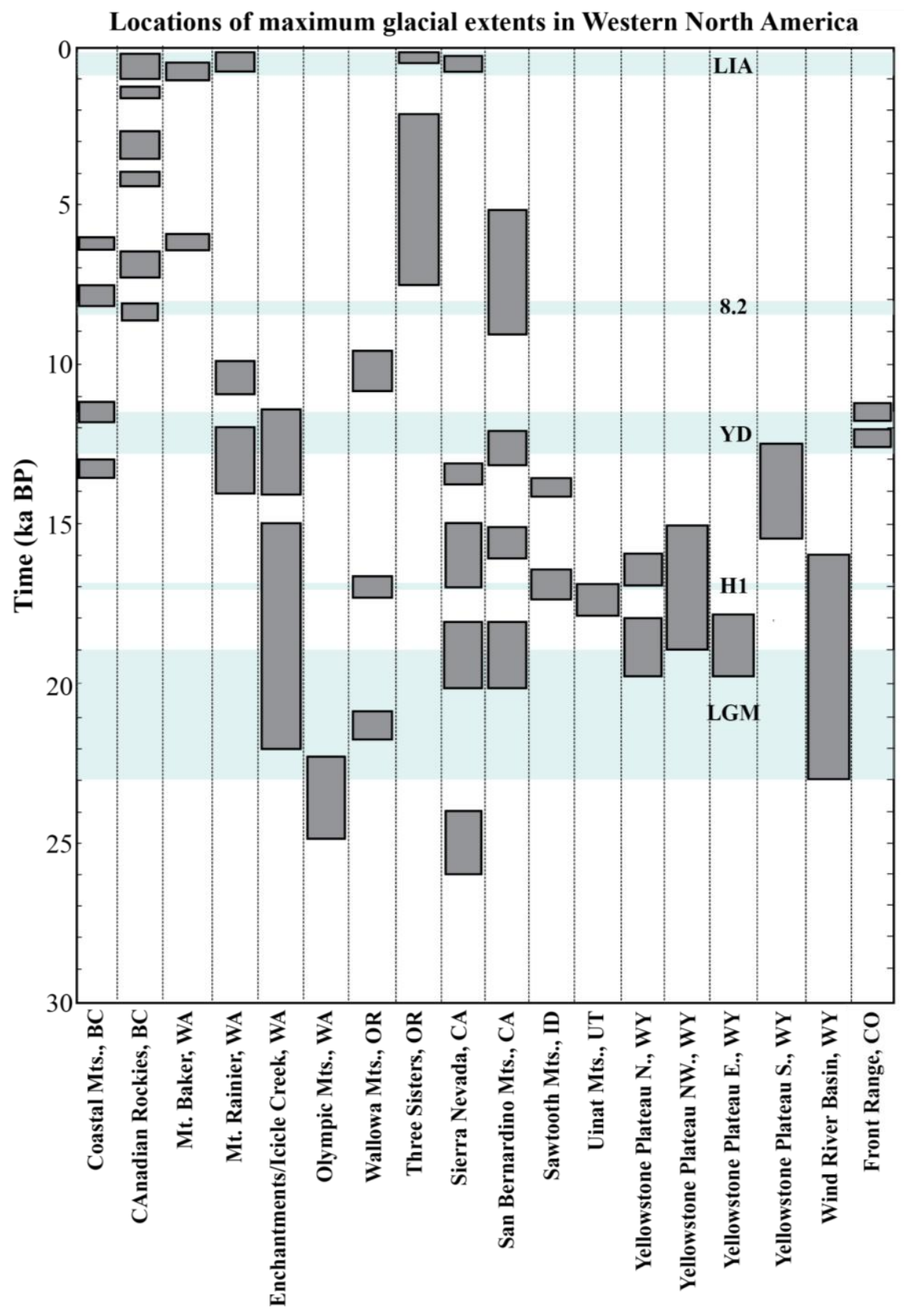

Figure 40: Western United States glacial advances in relation to distinct cooling events (blue shadings). 
The onset of the Younger Dryas (YD) cold period, near the end of the Pleistocene ( 11.7 ka BP) (Walker et al., 2008), is believed to have been caused by a sudden weakening of the North Atlantic's thermohaline circulation in response to an increase of freshwater from the melting Laurentide ice sheet (Anderson et al., 2007). In western North America, data suggest that glaciers advanced three times near the end of the Pleistocene: one before, another during, and a third after the YD stade (Figure 40). Evidence for a pre-YD advance ( 13.1 ka BP) is found on the Enchantment Mountains and at Mt. Rainier in the Cascades of Washington, in the Sawtooth Mountains, in the Colorado Front Range, the Canadian Rockies, and the Sierra Nevada (Porter and Swanson, 2008; Heine, 1998; Thackray et al., 2004; Menounos and Reasoner, 1997; Reasoner et al, 1994; Clark and Gillespie, 1997) (Figure 40). During the YD, many cirque glaciers deposited moraines at outer cirque edges in the Rat Creek Advance in the Icicle Creek Basin near the Enchantment Mountains, Washington, in the San Bernardino Mountains of southern California, and in the Front Range of Colorado (Porter and Swanson, 2008; Owen et al., 2003; Menounos and Reasoner, 1997). Lake sediments in the Canadian Rockies in Alberta, Canada and the Enchantment Lakes Basin of Washington further suggest temporal equivalence of glacial advances with the YD (Reasoner et al., 1994; Bilderback, 2004). Dating on moraine boulders in the Wallowa Mountains in Oregon and dates on organic sediments at Mt. Rainier indicate that glaciers advanced just after the Younger Dryas at $\sim 10.3$ ka BP (Licciardi et al., 2004; Heine, 1998) (Figure 39). 
Even though no absolute age has been assigned to the LPEH advance in the Goat Rocks, I compared the glacial geologic evidence found in the Goat Rocks with similar but dated evidence in other Cascade glaciated regions to infer timing of the LPEH advance. LPEH glacial deposits were mapped downstream from the Packwood Glacier, McCall Glacier-A, and Meade Glacier. The lateral and terminal moraines used to map the LPEH extents are covered with up to $80 \%$ vegetation and at least $30 \mathrm{~cm}$ of soil. Soil pits were dug on the proximal foot slope, crest, and leeward side of a terminal moraine below McCall Glacier-A. One ash layer, superimposed on glacial outwash correlated to till of the terminal moraine, was MSH W (1480 AD) indicating that the terminal moraine was in place before $1480 \mathrm{AD}$. The general lack of ash deposits in the moraine soil suggests the moraine was formed not too long before the $1480 \mathrm{MSH}$ eruption. The next oldest ash layer dates to back to $2.5 \mathrm{ka}$ BP (Castle Creek Period, Spirit Lake, Set B). However, the abundance of ash deposits found on the southern slopes in the Goat Rocks suggest that volcanic ashes deposited on the moraine's surface may have been eroded. The abundance of glacial melt water (which removed entire sections of moraine deposits) snowmelt, precipitation, strong eolian processes, and the shallow depth $(2 \mathrm{~cm})$ to the $\mathrm{B}$ horizon supports the possibility of ash deposits having been eroded away.

Morphometric measurements on the LPEH moraines resulted in a mean proximal slope of $20.0^{\circ}$, about $14^{\circ}$ shallower than the average LIA slope angle. The mean proximal slope angle correlates well with the Pilgrim Cove deposits near McCall, Idaho, suggested to have been deposited $\sim 14 \mathrm{ka} \mathrm{BP}$ (Colman and Pierce, 1986). Further, a study conducted by Putkonen and O’Neal (2006), which considered morphometric measurements on 
moraines from numerous regions, found that the average slope angle of the youngest Pleistocene moraines (i.e. Younger Dryas age) is $23^{\circ}$, which closely matches moraine measurements on the Goat Rocks LPEH deposits. Thus, while ash deposits fail to confine an age of the LPEH deposits, morphometric measurements, soil characteristics, and stratigraphic positioning suggest these deposits are either early Holocene or YD in age. Markedly, many moraines discovered directly downstream from LIA moraines in the western United States have been determined to be Younger Dryas in age, while deposits from other Holocene advances remain uncommon (Davis et al., 2009; Doug Clark pers. comm.).

Radiocarbon dated paleo-lake deposits discovered downstream from the McCall Glaciers, the Glissade Glacier, and the Tieton Glacier indicate that a lake existed as recently as 14,140 to 13,940 cal. yr BP. Although no clear evidence of moraine deposits were discovered, glacial erratics resting on a canyon wall near the modern river valley suggest that the lake basin was likely filled and emptied due to the deposition and erosion of a terminal moraine or recessional moraine, respectively. A lake created by a terminal moraine suggests that glaciers in the Goat Rocks may have advanced during the early Younger Dryas stadial. A lake created by a recessional moraine suggests that the glaciers in the Goat Rocks may have experienced a standstill before the Younger Dryas stadial as the LGM glacier ablated. Notably, glacial-lacustrine sediments in the Sawtooth Mountains of Idaho were deposited at 13,950 cal. yr BP, the same age as those lake sediments in the Goat Rocks (Thackray et al.,2004). This advocates that the event in the Goat Rocks is not an isolated episode and that ice volume in the Goat Rocks and in other 
regions, such as the Sawtooth Mountains, increased, maintained, or reestablished during the post-LGM/ pre-YD time.

\subsubsection{The H1 event and LGM}

The relatively brief Heinrich 1 (H1) event $(\sim 17 \mathrm{ka}$ BP) in the North Atlantic occurred more than $3 \mathrm{ka}$ after the global LGM climaxed and introduced another glacial period by decreasing the strength of the ocean thermohaline circulation (Heinrich, 1988; Clark and Bartlein, 1995) (Figure 39). Currently, glacial advances that temporally match the $\mathrm{H} 1$ event have only been distinguished from LGM deposits by absolute dating methods and/or relative stratigraphic positions. Dating of moraine boulders in the Uinta Mountains of northeastern Utah, the Icicle Creek basin in the Cascades, the Wallowa Mountains in northeastern Oregon, the Wind River Range and the Yellowstone plateau in the Central Rockies, in the Sierra Nevada Mountains, and in the San Bernardino Mountains of Southern California record glacial advances between $17.4 \pm 0.5{ }^{10} \mathrm{Be} \mathrm{ka} \mathrm{BP}$

and $16.1 \pm 1.1{ }^{36} \mathrm{Cl}$ ka BP that coincide with cooling effects of the $\mathrm{H} 1$ event (Refsnider et al., 2008; Porter and Swanson, 2008; Licciardi et al., 2004; Chadwick et al., 1997; Phillips et al., 1997; Gosse et al., 1995; Licciardi, 2001; Phillips et al., 1996; Owen et al., 2003) (Figure 39). Further, ${ }^{14} \mathrm{C}$ dates in the Sawtooth Mountains of Idaho suggest glaciers advanced to maximum positions at 16.9 ka BP, concurrent with the H1 event (Thackray et al., 2004). It was not possible to constrain the glacial evidence found in the Goat Rocks to the $\mathrm{H} 1$ event. 
In northwestern Wyoming and southern Montana, the periphery of the Yellowstone Plateau was covered by a large glacial system that culminated near the end of the LGM (18.8 \pm 0.9 to $16.5 \pm 1.4{ }^{10} \mathrm{Be}$ ka BP) (Licciardi and Pierce, 2008). Less than $200 \mathrm{~km}$ from the Yellowstone Plateau, the Wind River Basin of northwestern Wyoming contains nested moraines that were deposited from $\sim 23$ to $16{ }^{36} \mathrm{Cl} \mathrm{ka} \mathrm{BP}$ as well as moraine boulders that indicate that the LGM was reached by $21.7 \pm 0.7{ }^{10} \mathrm{Be} \mathrm{ka} \mathrm{BP}$ and lasted until to $\sim 15.8 \pm 0.5{ }^{10} \mathrm{Be}$ ka BP (Chadwick et al., 1997; Phillips et al., 1997; Gosse, et al., 1995). Glacial advances occurred in the Wallowas of northeastern Oregon at $21.1 \pm$ $0.4{ }^{10} \mathrm{Be} \mathrm{ka} \mathrm{BP}$, in the Sierra Nevada at $25 \pm 1.0{ }^{36} \mathrm{Cl} \mathrm{ka} \mathrm{BP}$ and $19 \pm 1.0{ }^{36} \mathrm{Cl} \mathrm{ka} \mathrm{BP}$, and in the San Bernardino Mountains of southern California between $\sim 20{ }^{10} \mathrm{Be} \mathrm{ka}$ BP and 18 ${ }^{10}$ Be ka BP (Licciardi et al., 2004; Phillips et al., 1996; Owens et al., 2003) These dates suggest alpine glaciers in western North America contemporaneously advanced with glaciers near the continental divide during the LGM (Figure 39).

During the LGM $(21 \pm 2 \mathrm{ka} \mathrm{BP})$, continental glaciation advanced south of the Canada/USA border while alpine glaciers expanded forming ice caps that blanketed many mountain ranges (Porter and Swanson, 1998; Refsnider et al., 2008; Licciardi et al., 2001). Although the LGM culminated globally at $21 \pm 2$ ka BP (Licciardi et al., 2004), glaciers throughout western North America reached maximum positions from $\sim 25$ to $\sim 16$ ka BP. In the Olympic Mountains of western Washington, organic material and stratigraphic data indicate that glaciers reached their furthest extents during the early stages of the LGM ( 24.8 and $22.4 \mathrm{ka} \mathrm{BP})\left(22.0-19.3\right.$ and $\left.19.1-18.3{ }^{14} \mathrm{C} \mathrm{ka} \mathrm{BP}\right)$ (Thackray, 2001). Less than $120 \mathrm{~km}$ north of the Goat Rocks Wilderness, ${ }^{36} \mathrm{Cl}$ dated 
moraine boulders in the Enchantment Mountains of the Cascade Range suggest that glaciers there reached maximum positions at $19.1 \pm 3.0 \mathrm{ka} \mathrm{BP}, 3000$ years after those in the Olympics (Porter and Swanson, 2008). Evidence suggests that glaciers in the Goat Rocks reached there maximum extents during the LGM.

In the Goat Rocks, modern glaciers were much more extensive and reaching the Rimrock Lake during the LGM. A right lateral moraine near Rimrock Lake contained a Btj horizon, a horizon that indicates an increase in pedogenic clay but not enough of an increase to meet criteria for the diagnostic argillic (Bt) horizon (Birkeland, 1999). This type of horizon is typically uncommon in Holocene aged alpine soils and becomes more frequent in alpine soils of the late Pleistocene. While alpine soil data, referring to relative dating of moraine soils, in the Cascade Range is limited, a Btj horizon was found in the crest of Tioga aged (20 ka BP) moraine in the eastern Sierra Nevada in California (Birkeland and Burke, 1988). The Rimrock right lateral moraine contained an average proximal slope of $15.3^{\circ}$, was completely covered with vegetation, and contained a soil cover at least $50 \mathrm{~cm}$ thick. In addition to its great distance from the glacial headwalls (> $30 \mathrm{~km}$ ), these data suggest the right lateral moraine was deposited during a substantial glacial period; probably the LGM. In contrast, the great distance between the Rimrock right lateral moraine and glacial headwalls also correlates well with locations of moraines (Mountain Home type or older) seen in the Enchantments (>70.9 ka BP) (Porter and Swanson, 2008). However, if the Rimrock right lateral moraine was deposited during that time, moraine soil characteristics should be older and more mature than observed. Therefore, I assign the Rimrock Lake moraine to LGM. 


\subsection{Goat Rocks glacier areas and ELAs}

My estimate of total modern glacier area on the northern and northeast slopes of the Goat Rocks highest peaks is $1.63 \pm 0.05 \mathrm{~km}^{2}$. In comparison, the Conrad, Meade, McCall and an unnamed glacier were estimated, by aerial photography, to cover $1.65 \mathrm{~km}^{2}$ (Bidlake, 2007). Notably, it is unclear whether Bidlake (2007) separated snow field coverage from more permanent glacier coverage, which I did. Between 1955 and 2009, the area decreased by an area weighted average of $54.3 \%$ and a glaciers equalized average of 53.6\%. This is similar to Bidlake's (2007) estimate for Conrad Glacier of a $49 \%$ area loss from 1970 to 2004. Based on three similar but different methods of estimating ELA (AAR, AA, and BR), modern ELAs range from 2031 to $2279 \mathrm{~m}$ asl with an average of $2163 \mathrm{~m}$ asl. The $\sim 200 \mathrm{~m}$ range in elevation may be a result of varying glacier aspects. Packwood Glacier, the only modern glacier residing on a northern slope, extends down to $1700 \mathrm{~m}$ asl and has an ELA of $2031 \mathrm{~m}$ asl, while every other glacier rests on northeastern slopes and has an average ELA of $2166 \mathrm{~m}$ asl (BR ELA estimates).

When considering glacial ELAs along the Sierra Nevada and Cascade Range crests, the average modern ELA in the Goat Rocks is comparatively low in elevation (Figure 41). Factors such as glacier aspect (all Goat Rocks glaciers reside on northern and northeastern slopes) and deep shading, which decrease ablation rates, and snow and ice avalanches, which increase snow accumulation in accumulation zones, allow the small Goat Rocks glaciers to maintain depressed ELA elevations. Notably, other regions with small alpine glaciers, such as the Enchantments Mountains in Washington and Three Fingered Jack in Oregon, also maintain low ELA elevations (Bilderback, 2004; Scott, 
1977). Conversely, larger glaciers on Mt. Rainier, Mt. Baker and Mt. Shasta (Hekkers, 2010; Kovanen and Slaymaker, 2005; Howat et al., 2007), which acquire more direct sunlight and are not as influenced by snow and ice avalanches, maintain higher ELA elevations (Figure 41). Anomalously, the relatively low modern ELA elevation of $~ 2400$ $\mathrm{m}$ for the Eliot Glacier, a large glacier on Mt. Hood, may be a result of its debris covered terminus which could reduce melt (Figure 41) (Jackson, 2007). Therefore, since many factors influence alpine glacier ELA elevations, these factors should be considered for future ELA estimates when larger alpine glaciers become smaller due to climate change.

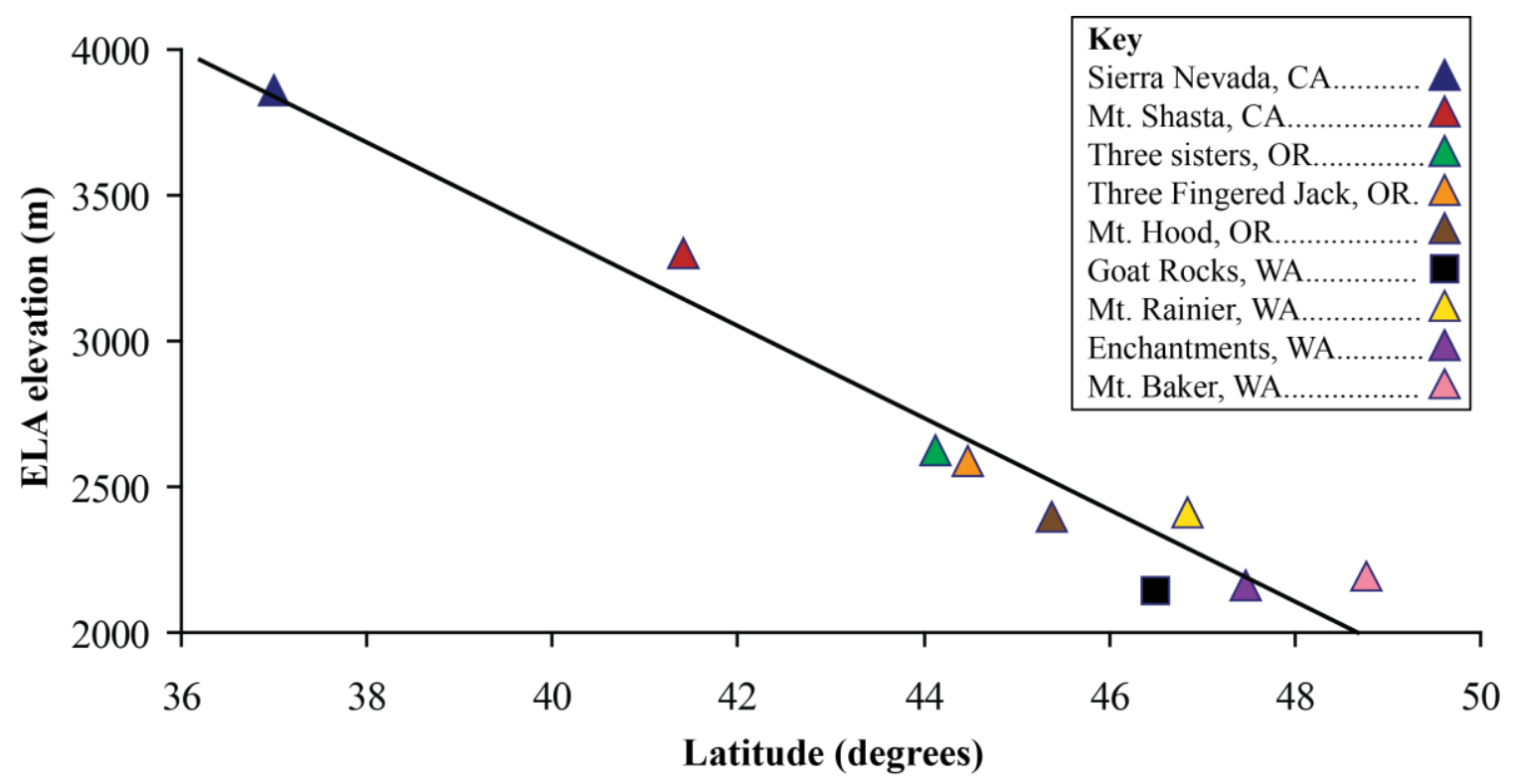

Figure 41: Equilibrium line altitude elevations versus latitude for glacial regions in the western United States. The black line represents a general decline of ELA elevation with increasing latitude. This is a factor of decreased summer temperatures with increasing latitude.

Ten LIA glaciers, including three currently extinct glaciers, covered an estimated area of $8.2 \mathrm{~km}^{2}$. LIA equilibrium lines range in elevation from 1629 to $2118 \mathrm{~m}$ asl with 
an average of $1970 \mathrm{~m}$ asl. The average LIA glacier reached its maximum position $\sim 1.6$ $\mathrm{km}$ and $\sim 1.1 \mathrm{~km}$ downstream from glacier headwalls and current glacial termini, respectively. Thus, the average LIA ELA is $193 \mathrm{~m}$ below that of modern glaciers, and is similar to ELA differences of $160 \mathrm{~m}$ and $110 \mathrm{~m}$ on Mt. Rainier and on the Three Sisters, respectively (Burbank, 1982; Marcott, 2005). Conversely, the LIA ELA is $~ 285$ m below the modern ELA on Mt. Baker, suggesting that either LIA glaciers there were more extensive than in the Goat Rocks or that Goat Rocks glaciers have receded more than the glaciers on Mt. Baker since the LIA (Thomas et al., 2000).

The three LPEH glaciers covered an estimated area of $3.8 \mathrm{~km}^{2}$. LPEH equilibrium lines average at $1904 \mathrm{~m}$ asl (BR method), which is $36 \mathrm{~m}$ and $237 \mathrm{~m}$ lower than ELAs of the same three LIA and modern glaciers, respectively. A study in the Enchantment Lake Basin, WA showed an ELA depression of $20 \mathrm{~m}$ from the LIA to an early Holocene advance (Waitt et al., 1982), similar to the ELA depression of $36 \mathrm{~m}$ between the LIA and LPEH advance in the Goat Rocks. Given that glaciers in the Enchantments Basin and the Goat Rocks Wilderness are in close proximity (less than $120 \mathrm{~km}$ apart), they experienced very similar climates and reacted similarly to those climates. Additionally, LPEH moraines of the Goat Rocks and the Brisingamen moraines (which also rest directly downstream from LIA moraines) in the Enchantments were created by glaciers flowing on "bench-like" hypsometry's, and the change in the extent of the glaciated terrain strongly depends on hypsometry (Brocklehurst and Whipple, 2004). Further, the earlyNeoglacial (2.5 - $8 \mathrm{ka} \mathrm{BP}$ ) and Fountonner (suggested to be $10-12 \mathrm{ka} \mathrm{BP}$ ) advances in the Three Sisters Wilderness produced estimated ELAs $\sim 270 \mathrm{~m}$ and $320 \mathrm{~m}$ below modern 
glacier ELAs, respectively (Marcott, 2005). In relation to modern ELAs, both of these advances are slightly more extensive than the Goat Rocks LPEH advance. In comparison, the two advances on Mt. Rainier, that reached max extents before $13.2 \mathrm{ka} \mathrm{BP}$ (McNeeley I) and between 10.9 to $9.9 \mathrm{ka} \mathrm{BP}$ (McNeeley II), have estimated ELAs between 400 and $500 \mathrm{~m}$ below modern ELAs (Heine, 1998). This is up to twice the ELA depression seen in the Goat Rocks. An early Holocene ( $\sim 8.4$ to $\sim 9.5 \mathrm{ka} \mathrm{BP})$ advance and a YD ( 12.1 to 12.9 ka BP) advance on Mt. Baker have estimated ELAs 355 to $400 \mathrm{~m}$ below modern ELAs (Thomas et al., 2000; Kovanen and Slaymaker, 2005). Thus, Mt. Rainier, Mt. Baker, and the Three Sisters record more extensive early Holocene and late Pleistocene advances than the Enchantments and, perhaps, the Goat Rocks.

The estimated ELA of $1230 \mathrm{~m}$ asl for the McCieton LGM glacier is calculated at $919 \mathrm{~m}$ below the average modern ELA (BR method). This is similar to findings at Mt. Rainier, where the ELA depression during full glacial time was 950 to $1050 \mathrm{~m}$ (Heine, 1997). A similar estimated ELA of $1280 \mathrm{~m}$ was calculated for the LGM- aged (19.2 ka BP) glacier (Leavenworth 1 advance) that flowed from the Enchantment Basin down Icicle Creek (Porter and Swanson, 2008). A different ELA depression of $1170 \mathrm{~m}$ is calculated by using modern ELAs from Waitt et al., (1982) and Porter and Swanson's (2008) LGM ELA, which implies that the modern ELA is $~ 100 \mathrm{~m}$ different between the two sources. Another study by Burbank (1991) produced similar estimates by determining that ELAs during full glaciation (LGM) in the southern and central Sierra Nevada were between 900 and 1000 m below modern ELAs. 


\subsection{Climate Implications}

For LIA glacial conditions the modern mean summer temperature would need to cool by $0.2-1.3{ }^{\circ} \mathrm{C}$, with no change in winter accumulation. This correlates well with both the estimated local cooling of about $1.0{ }^{\circ} \mathrm{C}$ inferred from LIA glacial extents on Mt. Rainier (Burbank, 1982), a measured (Jones and Briffa, 1992) global instrument recorded increase of $0.5{ }^{\circ} \mathrm{C}$ since the middle of the $19^{\text {th }}$ century, and temperature records from Greenland (Alley, 2000) (Figure 42). Alternatively, the modern maximum winter accumulation would need to increase by $7.6-42.6 \mathrm{~cm}$ weq., with no change in mean summer temperature, to result in the same ELA depression. However, on Mt. Rainier, winter accumulation rates in 1850 were only $7 \%(8 \mathrm{~cm})$ greater than they were in 1978 (Burbank, 1982). Thus, this implies that mean summer temperature, not winter precipitation accumulation, may be primarily responsible for the LIA ELA depression in the Goat Rocks.

To accommodate climate conditions necessary for glaciers to reach LPEH ELAs, the mean summer temperature would need to cool by $1.4-1.5^{\circ} \mathrm{C}$ and/or the maximum winter accumulation would need to increase $46.6-48.2 \mathrm{~cm}$ weq from climate conditions at modern ELAs. For the LPEH ELA conditions to fall within the modern climate envelop the mean summer temperature would need to cool by $1.0-3.5^{\circ} \mathrm{C}$ and/or winter accumulation would need to increase $46.4-156.0 \mathrm{~cm}$ weq. Assuming the LPEH advance in the Goat Rocks is early Holocene aged, it's estimated climate correlates well to early Holocene ELA depression data ( 100 m different than correlative Goat Rocks data) from Mt. Baker, which suggests a climate $\sim 2{ }^{\circ} \mathrm{C}$ cooler than at present, and $\sim 0.5{ }^{\circ} \mathrm{C}$ cooler 
than the LIA (Thomas et al., 2000). Few lines of evidence in the Cascades conclusively support early Holocene glacial advances other than on Mt. Baker (Thomas et al., 2000) and on Mt. Rainier (Heine, 1997). Notably, Hekkers (2009) used statistical models to predict Holocene advances on Mt. Rainier at 3.4, 6.5, 8.2, 9.3, 10.1 and $11.0 \mathrm{ka} \mathrm{BP}$, suggesting at least five advances since the end of the Younger Dryas. While pollen data from the Puget lowlands indicate the early Holocene experienced a drier and warmer climate than at present (Thompson et al., 1993), Heine (1998) proposes that low winter insolation during that time would create wetter and colder winters that could overshadow warm sea surface temperatures and promote glacier growth. 


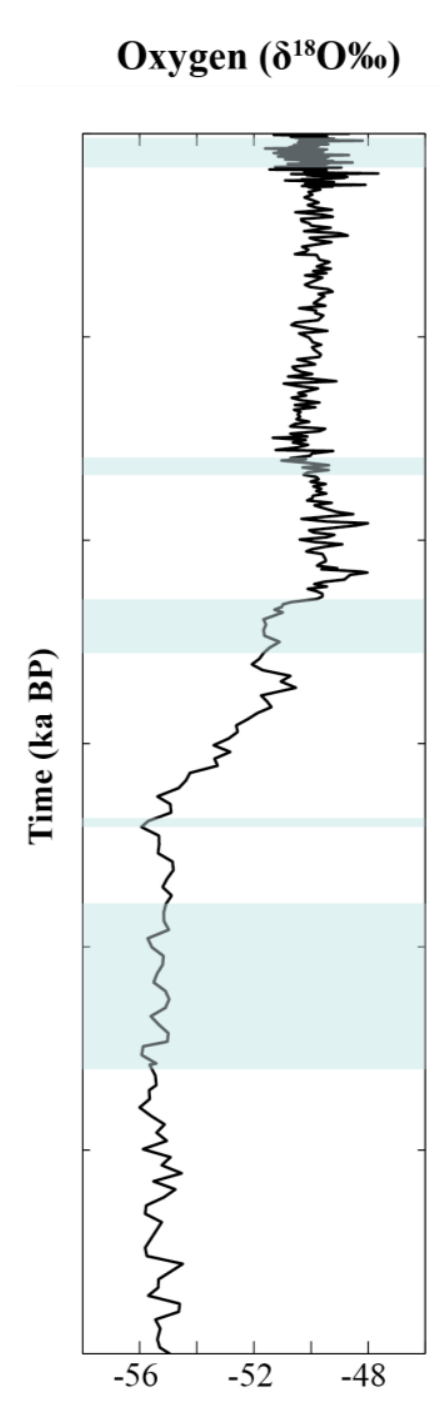

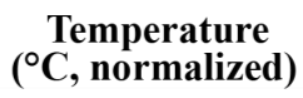

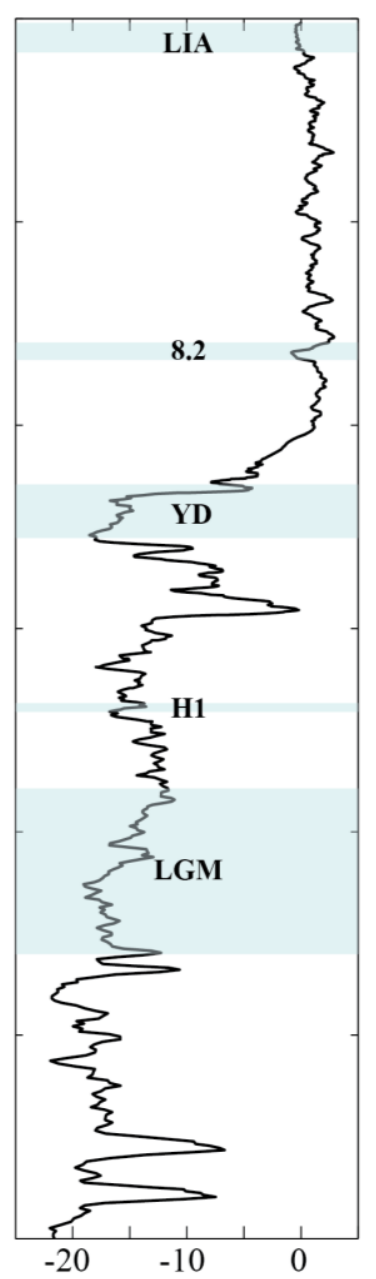

\section{Insolation $60^{\circ} \mathrm{N}$ \\ (langleys/day)}

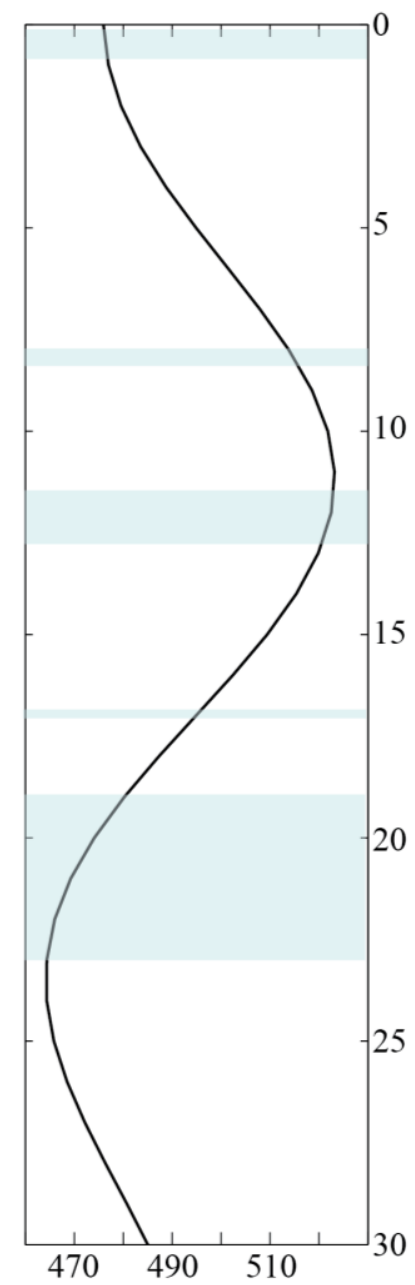

Figure 42: Oxygen (delta ${ }^{18} \mathrm{O}$ ), temperature, and incoming solar radiation (insolation) in relation to distinct cooling events (blue shadings). Oxygen data were collected at Dome $\mathrm{C}$ in Antarctica, temperature data were collected in central Greenland, and insolation data represent the Earth at $60^{\circ}$ N (adapted from Lorius et al., 1979; Alley, 2000; and Berger and Loutre, 1991, respectively).

If the LPEH advance occurred during the YD the Goat Rocks climate data would be consistent with work done in the Enchantments, WA and at Mt. Baker, WA (Bilderback, 2004; Kovanen and Slaymaker, 2005). Bilderback (2004) determined that the climate required to bring the Brisingamen advance (YD aged) into the climate 
envelope requires a maximum cooling of $3{ }^{\circ} \mathrm{C}$ or the winter precipitation would need to increase by a maximum of $88 \mathrm{~cm}$ weq. Estimated ELAs for the Deming Glacier on Mt. Baker suggest a temperature depression between $2.2-2.5^{\circ} \mathrm{C}$, with no change in winter accumulation (Kovanen and Slaymaker, 2005). If the LPEH moraines in the Goat Rocks are YD in age, they should record a climate estimated to have been warmer and wetter than during the LGM, but still cooler than at present (Whitlock et al., 2000). This implies that some combination of a mean summer temperature depression and an increase of winter accumulation occurred to accommodate LPEH ELA estimates in the Goat Rocks.

Climate calculations indicate that to maintain the McCieton LGM Glacier's ELA the estimated mean summer temperature would need to decrease $5.5^{\circ} \mathrm{C}$ or the estimated winter accumulation would need to increase by $179.1 \mathrm{~cm}$ weq from climate conditions at modern ELAs. During the LGM (MIS-2), the Pacific Northwest climate was likely influenced by the Laurentide Ice Sheet. The ice sheet was large enough to shift the North American jet stream and the major storm systems south, through the southwestern US, leaving northwest Washington cold and dry (Thackray, 2008). Consequently, it appears likely that the Goat Rocks experienced a large decrease in temperature and precipitation. Further, paleo-environmental data from the LGM suggests a Pacific Northwest temperature depression between $5-10^{\circ} \mathrm{C}$, which correlates well with LGM temperature estimates in the Goat Rocks (Thompson et al., 1993). 


\subsection{Conclusions}

Since the late Pleistocene glacier deposits in and near the Goat Rocks record three glacial stands. Lichenometric dating, moraine morphometries, stratigraphic positions, soil characteristics, ash deposits, radiocarbon analysis, and vegetation cover were used to establish absolute and relative dates of the Goat Rocks glacier deposits. Lichenometric dating indicates that the youngest glacier deposits were deposited between 110 and 139 years BP during the LIA. These dates correlate well with other LIA glacial stands in the Cascades. ELA reconstructions indicate a $154 \mathrm{~m}$ depression from the modern ELA of $2149 \mathrm{~m}$. This depression can be explained by a cooling of $1.0^{\circ} \mathrm{C}$ with no change in precipitation. Moraines directly downstream from the LIA moraines were deposited before the LIA. Although the date of deposition is not clear, morphometric data, soil characteristics, stratigraphic position and vegetation cover consistent with other western United States moraines suggest them to be either early Holocene or Younger Dryas in age. No evidence was discovered to suggest the Goat Rocks glaciers experienced early or middle Neoglacial advances. Notably, laminated lake sediments, dated at 14,140 to $13,940 \mathrm{ka} \mathrm{BP}$, are suggested to have been deposited in response to a glacial stand before the Younger Dryas stadial. Although uncertain, deposition scenarios imply that a late Pleistocene glacial stand, either from the retreating LGM glacier or an early YD advance, occurred in the Goat Rocks. A pre-Younger Dryas glacial stand would have required reinvigoration of moisture into Pacific Northwest of the United States. It is proposed that

glaciers in the northwestern United States responded to post-LGM increases in westerly 
atmospheric flow of moisture (Thackray et al., 2004). Nevertheless, if the deposits directly downstream from the LIA moraines are early Holocene in age, they would correlate well with glacial stands on Mt. Rainier (Heine, 1997), in the Three Sisters (Marcott et al., 2009), and in the Coast Mountains of British Columbia (Menounos et al., 2004). Younger Dryas deposition supports YD glacial stands at Mt. Baker (Kovanen and Slaymaker, 2005; Thomas et al, 2000) and in the Enchantments (Bilderback, 2004), but contrast with the lack of YD evidence at Mt. Rainier (Heine. 1997). LPEH ELA reconstructions indicate a $245 \mathrm{~m}$ depression from the modern ELA. If the reconstructed LPEH ELAs in the Goat Rocks represent an early Holocene advance, climate in the Goat Rocks is projected to have been colder and wetter than at present, and can be explained by a cooling of $1.5^{\circ} \mathrm{C}$ with no change in precipitation, an increase in precipitation of $\sim 47$ $\mathrm{cm}$ weq with no change in temperature, or, most likely, some combination of the two. If the reconstructed LPEH ELAs in the Goat Rocks represent a YD advance, climate in the Goat Rocks is projected to have been still colder than during the early Holocene, which can be explained by the maximum paleo-climate change in temperature of $3.5^{\circ} \mathrm{C}$ from the modern. The LGM moraines near Rimrock Lake are inferred from the soil and morphometric characteristics. An ELA depression of 919 m between modern ELAs and LGM ELAs in the Goat Rocks is similar to calculations at Mt. Rainier and in the Sierra Nevada (Heine, 1998; Burbank, 1991). This depression can be explained by a cooling of $5.6^{\circ} \mathrm{C}$ with no change in precipitation. 


\subsection{Future work}

The 1955 glacier extents, reconstructed from USGS maps glacier outlines, may not be completely accurate. While USGS glacier outlines were digitized from 1955 aerial photos it is unclear whether those outlines separate permanent snow (glacier ice) from seasonal snow. Further analysis of the 1955 aerial photos could provide more accurate glacier extents during that time. In addition, much of the terrain in the Goat Rocks is covered with thick vegetation which increases the difficulty in locating glacial deposits. It may be possible to better identify glacial deposits and more accurately reconstruct paleoglacier areas with the acquisition and analysis of LIDAR in the Goat Rocks.

Three glacier basins in the Goat Rocks contain LEPH moraines. Soil pits are dug into these deposits in only one basin, the McCall-A basin. By digging into LPEH moraines and locating datable material, such as organics or volcanic ashes, in the Meade and Packwood basins, ages of deposition could be better confined. Further, moraines on the northeast side of Rimrock Lake were mapped and classified by surficial appearances as pre-LGM deposits. However, no soil pits were dug to help determine their ages. In order to determine if these moraines were LGM or pre-LGM additional studies in this area should be conducted.

Lastly, two scenarios were presented that suggest the paleo-lake downstream from the Tieton Glacier, which existed at 14.1 - 13.9 ka BP, may have been created by a terminal moraine dam. While glacial erratics are located near the proposed terminal moraine dam location, it is possible that a different geomorphic process, such as a 
landslide, caused the lakes creation. Further investigation into identifying reasons for the lakes creation may provide insight about why the lake existed before the Younger Dryas. 


\section{References Cited:}

Alley,R.B., 2000, The Younger Dryas cold interval as viewed from Central Greenland: Quaternary Science Reviews, v. 19, p. 213-226.

Alley, R.B., Mayewski, P.A., Sowers, T., Stuiver, M., Taylor, K.C., and Clark, P.U., 1997, Holocene climatic instability: A prominent, widespread event 8200 yr ago: Geology, v. 25, p. 483-486.

Alley, R.B. and Ágústsdóttir, A.M., 2005, The 8k event: cause and consequences of a major Holocene abrupt climate change: Quaternary Science Reviews, v. 24, p. 1123-1149.

Anderson, D.E., Goudie, A.S., and Parker, A.G., 2007, Global Environments Through The Quaternary: Exploring Environmental Change: New York, Oxford University Press, $359 \mathrm{p}$.

Berger, A. and Loutre, M.F., 1991, Insolation values for the climate of the last 10 million of years: Quaternary Science Reviews, v. 10, p. 297-317.

Beget, J.E., 1984, Tephrochronology of Late Wisconsin deglaciation and holocene glacier fluctuations near Glacier Peak, North Cascade Range, Washington: Quaternary Research, v. 21, p. 304-316.

Beget, J.E., 1994, Tephrochonology, lichenometry and radiocarbon dating at Gulkana Glacier, central Alaska Range, USA: The Holocene, v.3, p. 307-313.

Benn, D.I. and Gemmell, A.M.D., 1997, Calculating equilibrium-line altitudes of former glaciers by the balance ratio method: a new computer spreadsheet: Glacial Geology and Geomorphology, http://ggg.qub.ac.uk/ggg

Benn, D.I. and Evans, D.J.A., 1998, Glaciers and Glaciation: London, Hodder Education, $734 \mathrm{p}$.

Berger, A. and Loutre, M.F., 1991, Insolation values for the climate of the last 10 million years: Quaternary Science Review, v. 10, p. 297-317.

Berry, M.E., 1994, Soil-geomorphic analysis of Late-Pleistocene glacial sequence in the McGee, Pine, and Bishop Creek drainages, East-Central Sierra Nevada, California: Quaternary Research, v.41, p. 160-175. 
Bidlake, W., 2007, Late $20^{\text {th }}$ Century Ice Loss in the Vicinity of the Goat Rocks, Tieton River Basin, Washington: Washington Hydrogeology Symposium, $6^{\text {th }}$, Tacoma, Washington, Abstracts, p. 20.

Bilderback, E.L., 2004, Timing and Paleoclimatic Significance of Latest Pleistocene and Holocene Cirque Glaciation in the Enchantment Lake Basin, North Cascades, WA [Masters thesis]: Bellingham, Western Washington University.

Birkeland, P.W., 1973, Use of relative age-dating methods in a stratigraphic study of rock glacier deposits, Mt. Sopris, Colorado: Arctic and Alpine Research, v. 5, p. 401-416.

Birkeland, P.W., Colman, S.M., Burke, R.M., Shroba, R.R., and Meierding, T.C., 1979, Nomenclature of alpine glacial deposits, or, What's in a name?: Geology, v. 7, p. 532-536.

Birkeland, P.W. and Burke, R.M., 1988, Soil catena chronosequences on eastern Sierra Nevada moraines, California, U.S.A.: Arctic and Alpine Research, v. 20, p. 473-484.

Birkeland, P.W., Berry, M.E., and Swanson, D.K., 1991, Use of soil catena field data for estimating relative ages of moraines: Geology, v.19, p. 281-283.

Birkeland, P.W., 1999, Soils and Geomorphology: New York, Oxford University Press, $430 \mathrm{p}$.

Birkeland, P. W., Shroba, R. R., Burns, S. F., Price, A. B., and Tonkin, P. J., 2003, Integrating soils and geomorphology in mountains-An example from the Front Range of Colorado: Geomorphology, v. 55, p. 329-344.

Borgert, J.A., 1999, Late Pleistocene Glaciation in the Sawtooth Mountains, Central Idaho: Relative Weathering Realtionships and Preliminary Radiocarbon Chronology [Masters thesis]: Idaho State University.

Brocklehurst, S.H. and Whipple, K.X., 2004, Hypsometry of glaciated landscapes: Earth Surface Processes and Landforms, v. 29, p. 907-926.

Burbank, D.W., 1981, A Chronology of Late Holocene glacier fluctuations on Mount Rainier, Washington: Arctic and Alpine Research, v. 13, p. 369-386.

Burbank, D.W., 1982, Correlations of climate mass balances, and glacial fluctuations at Mount Rainier, Washington, U.S.A., since 1850: Arctic and Alpine Research, v. 14, p. 137-148.

Burbank, D.W., 1991, Late Quaternary snowline reconstructions for the southern and central Sierra Nevada, California and a reassessment of the Recess Peak Glaciation: Quaternary Research, v. 36, p. 294-306. 
Campbell, N.P. and Gusey, D., 1992, Geology of the Naches Ranger District, Wenatchee National Forest, Kittitas and Yakima Counties, Washington: Washington Division of Geology and Earth Resources open File Report 92-3, 12 p.

Chadwick, O.A., Hall, R.D., and Phillips, F.M., 1997, Chronology of Pleistocene glacial advances in the central Rocky Mountains: Geological Society of America Bulletin, v. 109, p. $1443-1452$.

Clark, D.H. and Gillespie, A.R., 1997, Timing and significance of Late-Glacial and Holocene cirque glaciation in the Sierra Nevada, California: Quaternary International, v. 38/39, p. 21-38.

Clark, P.U. and Bartlein, P.J., 1995, Correlation of late Pleistocene glaciation in the western United States with North Atlantic Heinrich events: Geology, v. 23, p. 483-486.

Clark, P.U., Marshall, S.J., Clarke, G.K.C., Hostetler, S.W., Licciardi, J.M. and Teller, J.T., 2001, Freshwater forcing of abrupt climate change during the last glaciation: Science, v. 293, p. 283-287.

Clayton, G. A., 1983, Geology of the White Pass area, south-central Cascade Range, Washington [M.S. thesis]: University of Washington, 212 p.

Colman, S.M. and Pierce, K.L., 1986, Glacial sequence near McCall, Idaho: weathering rinds, soil development, morphology, and other relative-age criteria: Quaternary Research, v.25, p. 25-42.

Crandell, D.R. and Miller, R.D., 1974, Quaternary stratigraphy and extent of glaciation in the Mount Rainier region, Washington: United States Geological Survey Professional Paper 847, 59 p.

Davis, P.T., Osborn, G., Ryane, C., Menounos, B., and Clague, J., 2007, Little Ice Age fluctuations of glaciers on Mount Baker, Washington: Geological Society of America Abstracts with Programs, v. 39, n. 4, p. 82.

Davis, P.T., Menounos, B., and Osborn, G., 2009, Holocene and latest Pleistocene alpine glacier fluctuations: a global perspective: Quaternary Science Reviews, v. 28, p. 20212033.

Ellingson, J.A., 1968, Late Cenozoic Volcanic Geology of the White Pass-Goat Rocks Area, Cascade Mountains, Washington [Ph.D. thesis]: Washington State University, 112 p.

Fiske, R.S., Hopson, C.A., and Waters, A.C., 1963, Geology of Mount Rainier National Park, Washington: U.S. Geological Survey Professional Paper 444, 93 p. 
Furbish, D.J., and Andrews, J.T., 1984, Use of hypsometry to indicate long-term stability and response of valley glaciers to changes in mass transfer: Journal of Glaciology, v. 30, p. 199-211.

Gibbons, A.B., Megeath, J.D., and Pierce, K.L., 1984, Probability of moraine survival in a succession of glacial advances: Geology, v. 12, p. 327-330.

Gosse, J.C., Klein, J., Evenson, E.B., Lawn, B., and Middleton, R., 1995, Beryllium-10 dating of the Duration and retreat of the Last Pinedale Glacial Sequence: Science, v. 268, p. 1329-1333.

Gosse, J.C. and Phillips, F.M., 2001, Terrestrial in situ cosmogenic nuclides: theory and application: Quaternary Science Reviews, v. 20, p. 1475-1560.

Grove, J. M., 1988, The Little Ice Age. London, Routledge. 498 p.

Hekkers, M.L., 2010, Climatic and Spatial Variations of Mount Rainier's Glaciers for the Last 12,000 Years [Masters thesis]: Portland State University, 117 p.

Heine, J., 1997, Glacier advances at the Pleistocene/Holocene transition near Mount Rainier volcano, Cascade Range, USA [Ph.D. thesis]: University of Washington, 138 p.

Heine, J., 1998, Extent, timing, and climatic implications of glacier advances Mount Rainier, Washington, U.S.A., at the Pleistocene/Holocene transition: Quaternary Science Reviews, v.17, p. 1139-1148.

Heinrich, H., 1988, Origin and consequences of cyclic ice rafting in the Northeast Atlantic Ocean during the past 130,000 years: Quaternary Research, v. 29, p. 142-152.

Howat, I.M., Tulaczyk, S., Rhodes, P., Israel, K., Snyder, M., 2007, A precipitation dominated, mid-latitude glacier system: Mount Shasta, California: Climate Dynamics, v. 28, p. 85-98.

Innes, J.L., 1985, An examination of some factors affecting the largest lichens on a substrate: Arctic and Alpine Research, v.17, p. 99-106.

Jackson, K.M., 2007, Spatial and morphological change on Eliot Glacier, Mount Hood, Oregon, [Masters thesis]: Portland State University, 111 p.

Jackson, K.M. and Fountain, A.G., 2007, Spatial and morphological change on Eliot Glacier, Mount Hood, Oregon, USA: Annals of Glaciology, v. 46, p. 222-226. 
Marcott, S.A., 2005, A Tale of Three Sisters: Reconstructing the Holocene Glacial History and Paleo-climate Record at Three Sisters Volcanoes, Oregon, United States [Masters thesis]: Portland State University, 93 p.

Jomelli, V., Grancher, D., Naveau, P., Cooley, D., and Brunstein, D., 2007, Assessment study of lichenometric methods for dating surfaces: Geomorphology, v. 86, pp. 131-143.

Jones, P.D. and Briffa, K.R., 1992, Global surface air temperature variations during the twentieth century: Part 1, spatial, temporal and seasonal details: The Holocene, v.2, p. 165-179.

Kaufman, D.S. and Calkin, P.E., 1988, Morphometric Analysis of Pleistocene Glacial deposits in the Kigluaik Mountains, Northwestern Alaska, U.S.A.: Arctic and Alpine Research, v. 20, pp. 273-284.

Konrad, S.K. and Clark, D.H., 1998, Evidence for an Early Neoglacial glacier advance from rock glaciers and lake sediments in the Sierra Nevada, California, USA: Arctic and Alpine Research, v. 30, p. 272-284.

Kovanen, D.J. and Slaymaker, O., 2005, Fluctuations of the Deming Glacier and theoretical equilibrium line altitudes during the Late Pleistocene and Early Holocene on Mount Baker, Washington, USA: Boreas, v. 34, p. 157-175.

Kurowski, L., 1891, Die Ho“ he der Schneegrenze: Penck’s Geographische Abhandlungen, v. 124, p. 119-160.

Leonard, E.M., 1989, Climatic change in the Colorado Rocky Mountains: estimates based on modern climate at Late Pleistocene equilibrium lines: Arctic and Alpine Research, v. 21, p 245-255.

Leonard, K.C. and Fountain, A.G., 2003, Map-based methods for estimating glacier equilibrium-line altitudes: Journal of Glaciology, v. 49, p. 329-336.

Licciardi, J.M., Clark, P.U., Brook, E.J., Pierce, K.L., Kurz, M.D., Elmore, D., and Sharma, P., 2001, Cosmogenic ${ }^{3} \mathrm{He}$ and ${ }^{10} \mathrm{Be}$ chronologies of the late Pinedale northern Yellowstone ice cap, Montana, USA: Geology, v. 29, p. 1095-1098.

Licciardi, J.M., Clark, P.U., Brook, E.J., Elmore, D., Sharma, P., 2004, Variable responses of western US glaciers during the last termination: Geology, v. 32, p. 81-84. 
Licciardi, J.M. and Pierce, K.L., 2008, Cosmogenic exposure age chronologies of Pinedale and Bull Lake glaciations in greater Yellowstone and the Teton Range, USA: Quaternary Science Reviews, v. 27, p. 814-831.

Lorius, C., Merlivat, L., Jouzel, J., and Pourchet, M., 1979, A 30,000 yr isotope climatic record from Antarctic ice: Nature, v. 280, p. 644-648.

Luckman, B.H., Holdsworth, G., Osborn, G.D., 1993, Neoglacial fluctuations in the Canadian Rockies: Quaternary Research, v.39, p. 144-153.

Mahaney, B.D., Fahey, B.D., and Lloyd, D.T., 1981, Late Quaternary glacial deposits, soils, and chronology, Hell Roaring Valley, Mount Adams, Cascade Range, Washington: Arctic and Alpine Research, v. 13, p. 339-356.

Marcott, S.A., 2005, A Tale of Three Sisters: Reconstructing the Holocene Glacial History and Paleo-climate Record at Three Sisters Volcanoes, Oregon, United States [Masters thesis]: Portland State University, 93 p.

Marcott, S.A., Fountain, A.G., O'Conner, J.E., Sniffen, P.J., and Dethier, D.P., 2009, A latest Pleistocene and Holocene glacial history and paleo-climate reconstruction at Three Sisters and Broken Top Volcanoes, Oregon, USA: Quaternary Research, v. 71, p. 181189.

Matthes, F.E., 1939, Report of Committee on Glaciers: American Geophysical Union Transactions, v. 20, p. 518-523.

Meier, M.F., and Post, A.S., 1962, Recent variations in mass net budgets of glaciers in western North America: IUGG/IASH committee on Snow and Ice, General Assembly, v. 58, p. 63-77.

Menounos, B. and Reasoner, M.A, 1997, Evidence for Cirque Glaciation in the Colorado Front Range during the Younger Dryas Chronozone: Quaternary Research, v. 48, p. 3847.

Menounos, B., Koch, J., Osborn, J., Clague, J.J, Mazzucchi, D., 2004, Early Holocene glacier advance, southern Coast Mountains, British Columbia, Canada: Quaternary Science Reviews, v. 23, p. 1543-1550.

Menounos, B., Osborn, G., Clague, J.J., Luckman, B.H., 2009 Latest Pleistocene and Holocene glacier fluctuations in western Canada: Quaternary Science Reviews, v. 28, p. 2049-2074. 
Molenaar, D., 1985, Water in the Lower Yakima River Basin, Washington: USGS Water Supply Bulletin 53, 176 p.

Mullineaux, D.R., 1996, Pre-1980 Tephra-Fall Deposits Erupted From Mount St. Helens, Washington: U.S. Geological Survey Professional Paper 1563, 99 p.

NRCS, 2011, Natural Resources Conservation Service, www.wcc.nrcs.usda.gov. September, 2011.

O'Connor, J.E., Hardison, J.H.I, and Costa, J.E., 2001, Debris flows from failure of Neoglacial age moraine dams in the Three Sisters and Mount Jefferson Wilderness Area, Oregon: U.S. Geological Survey Professional Paper 1606, p.93.

O’Neal, M. A., 2005, Late Little Ice Age Glacier Fluctuations in the Cascade Range of Washington and northern Oregon [Ph.D. thesis]: University of Washington, 126 p.

O’Neal, M.A. and Schoenenberger, K.R., 2003, A Rhizocarpon geographicum growth curve for the Cascade Range of Washington and northern Oregon, USA: Quaternary Research, v. 60, p. 233-241.

Osborn, G., Menounos, B., Koch, J., Clague, J.J., and Vallis, V., 2007, Multi-proxy record of Holocene glacial history of the Spearhead and Fitzsimmons ranges, southern Coast Mountains, British Columbia: Quaternary Science Reviews, v. 26, 479-493.

Osmaston, H., 2005, Estimates of glacier equilibrium line altitudes by the area x Altitude, the area $\mathrm{x}$ altitude balance ratio and the area $\mathrm{x}$ altitude balance index methods and their validation: Quaternary International, v. 138-139, p. 22-31.

Owen, L.A., Finkel, R.C., Minnich, R.A., and Perez, A.E., 2003, Extreme southwestern margin of late Quaternary glaciation in North America: Timing and Controls: Geology, v. 31, p. 729-732.

Paterson, W.S.B., 1994, The Physics of Glaciers: $3^{\text {rd }}$ ed. Oxford, Pergamon, 480 p.

Phillips, F.M., Zreda, M.G., Benson, L.V., Plummer, M.A., Elmore, D., and Sharma, P., 1996, Chronology for fluctuations in late Pleistocene Sierra Nevada glaciers and lakes: Science, v. 274, p. 749-751.

Phillips, F. M., Zreda, M. G., Gosse, J. C., Klein, J., Evenson, E. B., Hall, R. D., Chadwick, O. A., and Sharma, P., 1997, Cosmogenic ${ }^{36} \mathrm{Cl}$ and ${ }^{10} \mathrm{Be}$ ages of Quaternary glacial and fluvial deposits of the Wind River Range, Wyoming: Geological Society of America Bulletin, v. 128, p. 1453-1463. 
Porter, S.C., 1977, Present and past glaciation threshold in the Cascade Range, Washington, U.S.A.: Topographic and climatic controls, and paleoclimatic implications: Journal of Glaciology, v. 18, p. 101-116.

Porter, S.C., 1981a, Glaciological evidence of Holocene climate change, In Wigley, T., M.L., Ingram, M.J., and Farmer, G., (eds.), Climate and History, Cambridge: Cambridge University, p. 82-110.

Porter, S.C., 1981b, Lichenometric studies in the Cascade Range of Washington: establishment of Rhizocarpon geographicum growth curves at Mt. Rainier: Arctic and Alpine Research, v.13, p. 11-23.

Porter, S.C., and Swanson, T.W., 2008, ${ }^{36} \mathrm{Cl}$ Dating of the classic Pleistocene glacial record in the northeastern Cascade Range, Washington: American Journal of Science, v. 308, p. 130-166.

Putkonen, J. and O’Neal, M., 2006, Degradation of unconsolidated Quaternary landforms in the western North America: Geomorphology, v. 75, p. 408-419.

Reasoner, M.A., Osborn, G., and Rutter, N.W., 1994, Age of the Crowfoot asdvance in the Canadian Rocky Mountains: a glacial event coeval with the Younger Dryas oscillation: Geology, v. 22, p. 439-442.

Refsnider, K.A., Laabs, B.J.C., Plummer, M.A., Mickelson, D.M., Singer, B.S., and Caffee, M.W., 2008, Last glacial maximum climatic inferences from cosmogenic dating and glacier modeling of the western Uinta ice field, Uinta Mountains, Utah: Quaternary Research, v. 69, p. 130-144.

Reynolds, R.C., 1971, Clay mineral formation in an alpine environment: Clays and Clay Minerals, v. 19, p. 361-374.

Ruhe, R.V., 1950, Graphic analysis of drift topographies: American Journal of Science, v. 248, p. 435-443.

Schasse, H.W., 1987, Geologic Map of the Mount Rainier Quadrangle, Washington: Washington Division of Geology and Earth Resources Open File Report 87-16, 47 p.

Scott, W.E., 1977, Quaternary Glaciation and Volcanism, Metolius River area, Oregon: Geological Society of America Bulletin, v. 88, p. 113-124.

Severinghaus, J.P. and Brook, E.J., 1999, Abrupt climate change at the end of the Last Glacial Period inferred from trapped air in polar ice: Science, v. 286, p. 930-934. 
Sitts, D.J., Fountain, A.G., and Hoffman, M.J., 2010, Twentieth Century glacier change on Mount Adams, Washington, USA: Northwest Science, V. 84, p. 378-385.

Soil Survey Division Staff, 1993, Soil Survey Manual: United States Department of Agriculture Handbook, No. 18, 437 p.

Stuiver, M. and P.J. Reimer., 1993, Radiocarbon calibration program Calib Rev 6.0.1: Radiocarbon, v. 35, p. 215-230.

Swanson, D.A. and Clayton, G.A., 1983, Generalized geologic map of the Goat Rocks wilderness and roadless areas (6036, Parts A,C, and D), Lewis and Yakima Counties, Washington: U.S. Department of the Interior Geological Survey Open-File Report 83-357, $10 \mathrm{p}$.

Thackray, G.D., 2001, Extensive early and middle Wisconsin glaciation on the western Olympic Peninsula, Washington, and the variability of pacific moisture delivery to the northwestern United States: Quaternary Research, v. 55, p. 257-270.

Thackray, G.D., Lundeen, K.A., Borgert, J.A., 2004, Latest Pleistocene alpine glacier advances in the Sawtooth Mountains, Idaho, USA: Reflections of midlatitude moisture transport at the close of the last glaciation: Geology, v. 32, p. 225-228.

Thackray, G.D., 2008, Varied climatic and topographic influences on Late Pleistocene mountain glaciation in the western United States: Journal of Quaternary Science, v. 23, p. 671-681.

Thomas, P.A., Easterbrook, D.J., and Clark, P.U., 2000, Early Holocene glaciation on Mount Baker, Washington State, USA: Quaternary Science Reviews, v. 19, p. 1043-1046.

Thompson, R.S., Whitlock, C., Bartlein, P.J., Harrison, S., and Spauling, W.G., 1993, Climatic changes in the western United States since 18,000 yr B.P.: global climates since the Last Glacial Maximum: Minneapolis, University of Minnesota Press, p. 468-513.

Waitt, R.B., Yount, J.C., and Davis, P.T., 1982, Regional Significance of an Early Holocene Moraine in Enchantment Lakes Basin, North Cascade Range, Washington: Quaternary Research, v. 17, p. 191-210.

Walker, M., Johnsen, S., Rasmussen, S.O., Steffensen, J.-P., Popp, T., Gibbard, P., Hoek, W., Lowe, J.J., Andrews, J., Björck, S., Cwynar, L., Hughen, K., Kershaw, P., Kromer, B., Litt, T., Lowe, D.J., Nakagawa, T., Newnham, R.M., and Schwander, J., 2008, The global stratotype section and point (GSSP) for the base of the Holocene Series/Epoch (Quaternary System/Period) in the NGRIP ice core: Episodes: Journal of International Geosciences v. 31, p. 264-267. 
Whitlock, C., Sarna-Wojcicki, A.M., Bartlein, P.J., and Nickmann, R.J., 2000, Environmental history and tephrostratigraphy at Carp Lake, southwestern Columbia Basin, Washington, USA: Palaeogeography, Palaeoclimatology, Palaeoecology, v. 155, p. 7-29.

Wood, C.A. and Kienle, J., 1990, Volcanoes of North America-United States and Canada: New York, Cambridge University Press, 354 p. 


\section{Appendix A: Soil Pit Stratigraphic Cross Sections and Descriptions}

Sixteen soil pits were dug in the summer of 2010 in the Goat Rocks Wilderness. Detailed field descriptions of all soil pits used soil horizon nomenclature from the Soil Survey Division Staff (1993). Generalized colors, shown in parentheses, are those recorded in the field when the soil was wet. Notation before the wet color represents dry color recorded in a lab using Munsell Soil Color charts. Cross sectional displays do not represent field appearances but are intended to exemplify the texture, form and other notable characteristics collected in each horizon. 


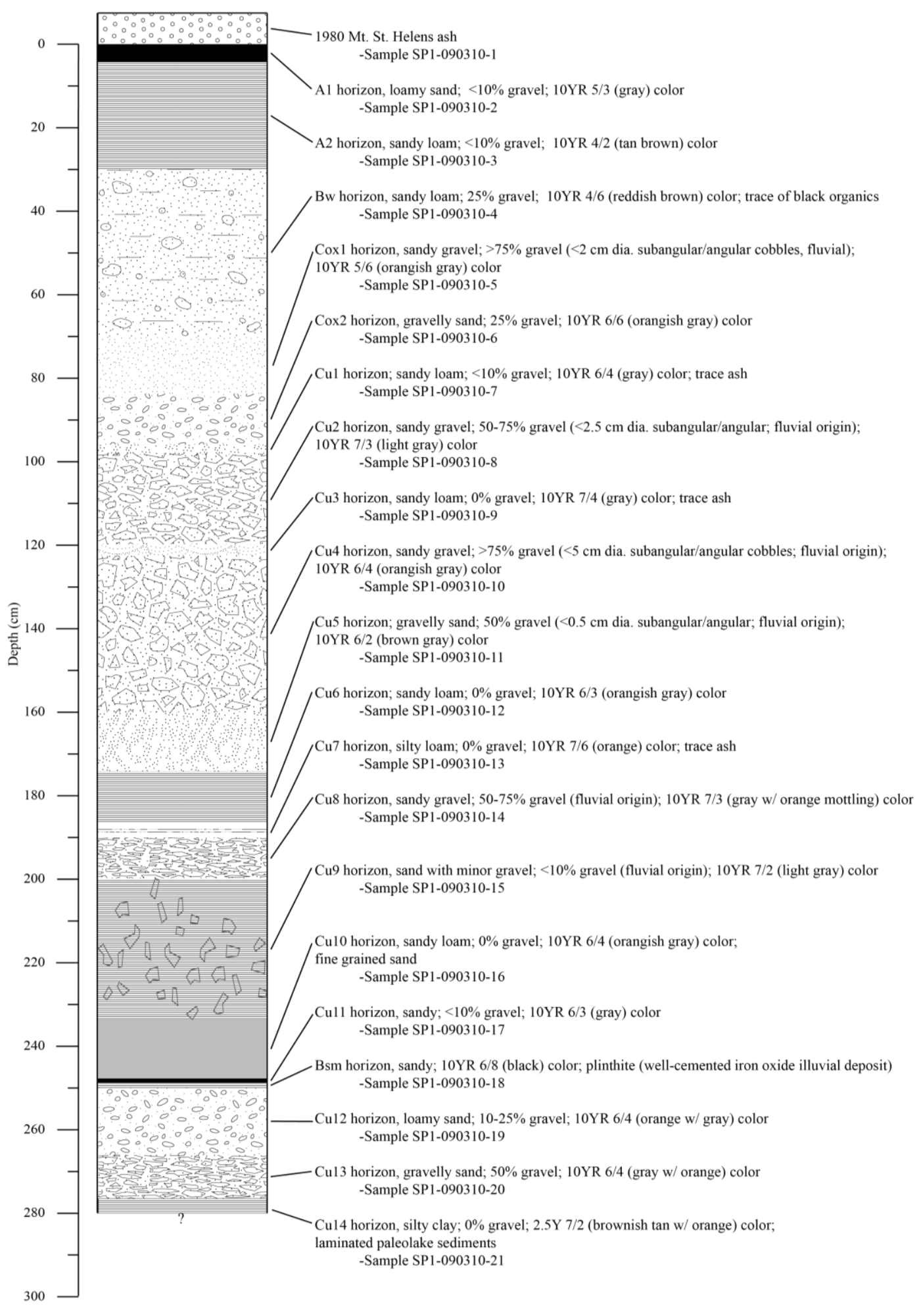

Figure A-1: Stratigraphic cross section of SP1, located downstream of the Tieton Glacier. Material overlies laminated lake sediments. UTM location: Easting 622017, Northing 5154027. 


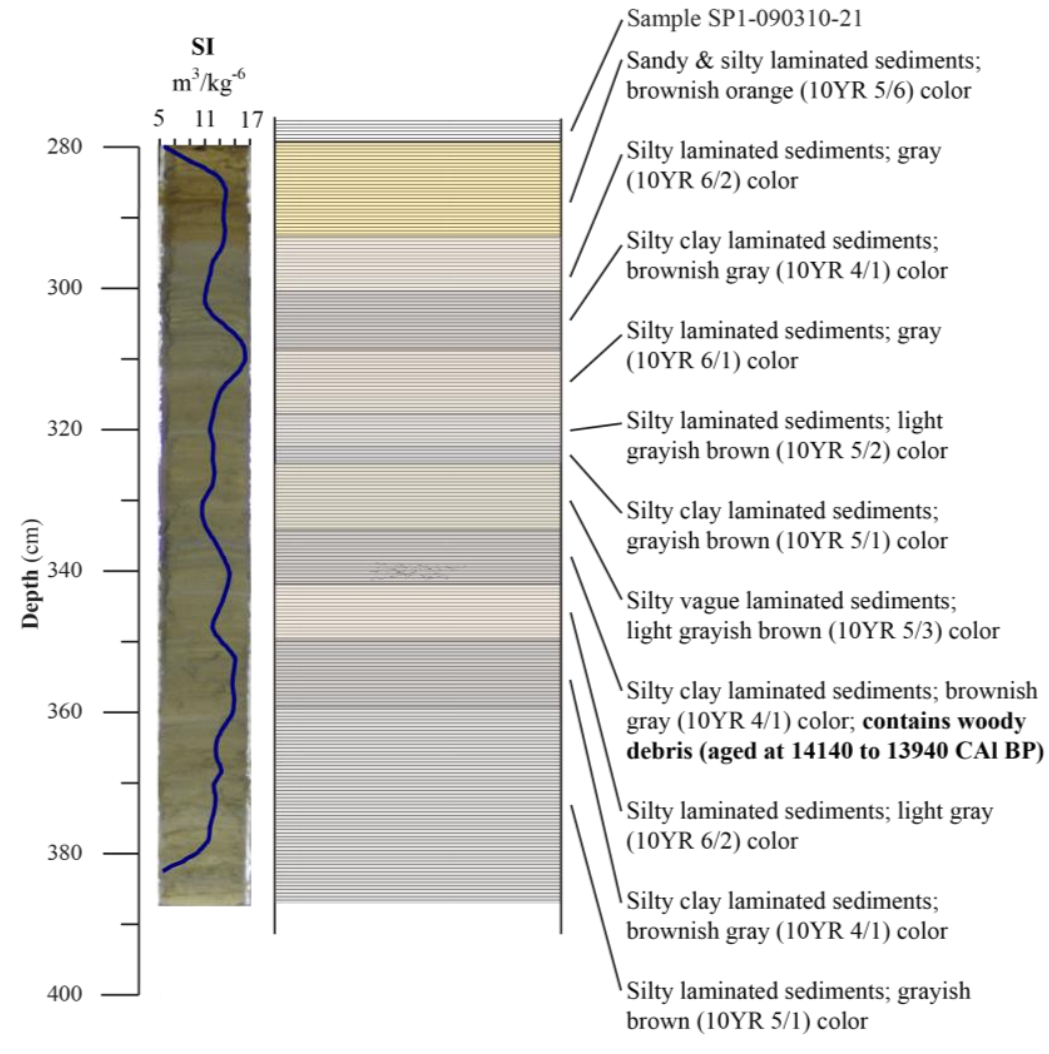

Figure 43: Paleo-lake sediments discovered below SP1 in the McCall Area. Laminated sediments are consistent through the entire collected core. Note the woody debris collected at $341 \mathrm{~cm}$ deep. Magnetic susceptibility (SI) is graphed in blue. UTM location: Easting 622017, Northing 5154027. 


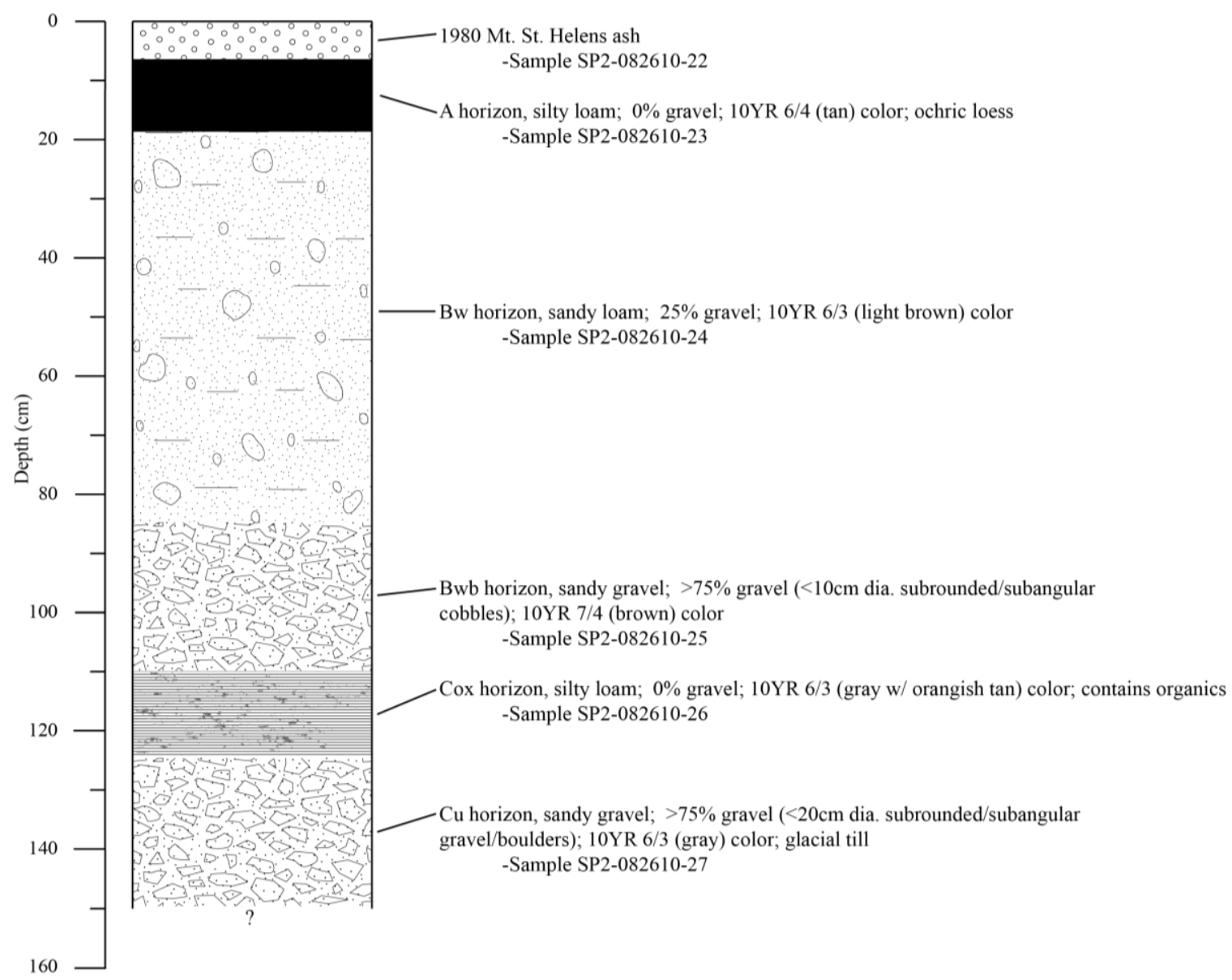

Figure A-3: Stratigraphic cross section of SP2, located downstream of the McCall Glacier-A in the McCall Area. Soil pit was dug on top of M1. UTM location: Easting 620506, Northing 5153923. 


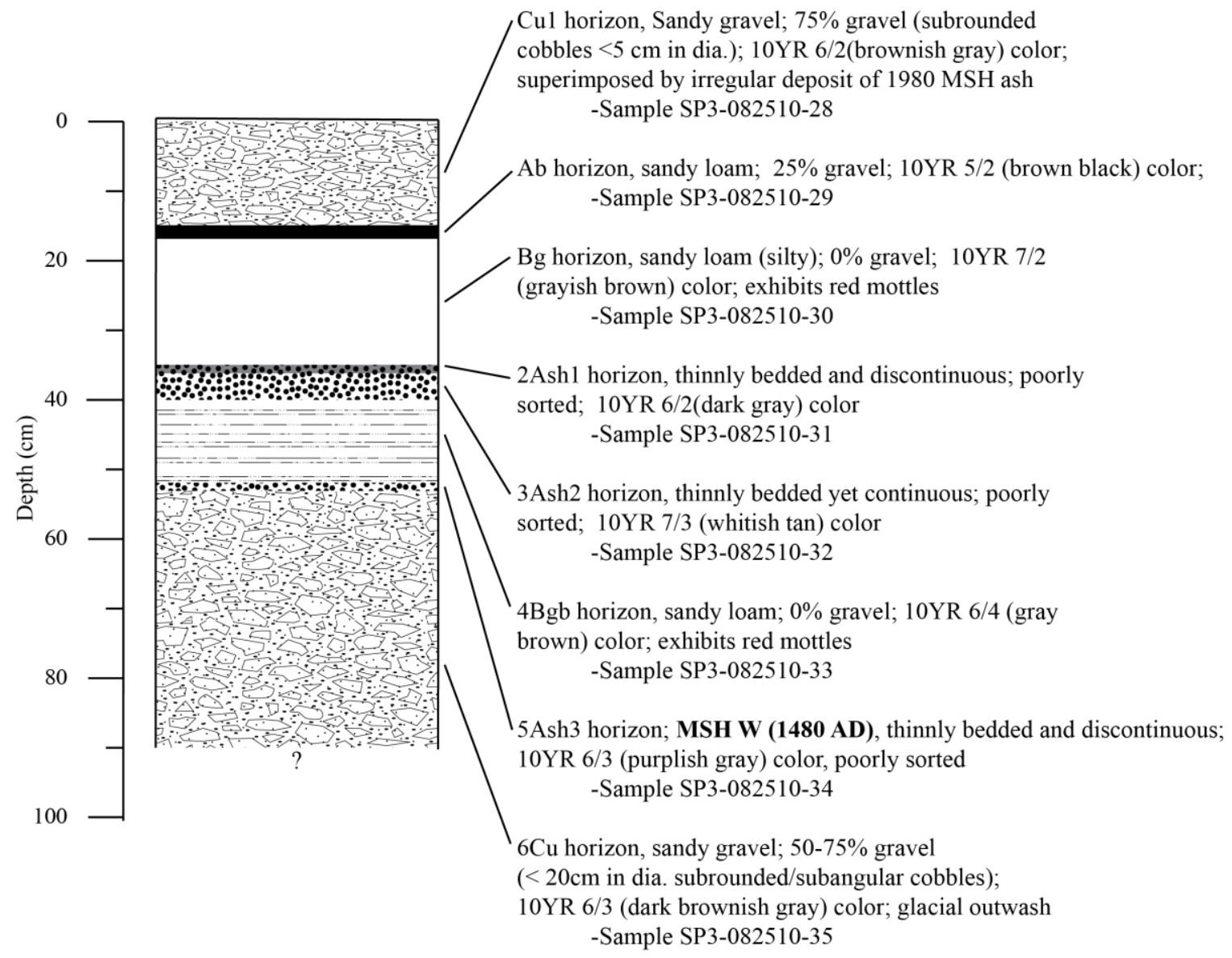

Figure A-4: Stratigraphic cross section of SP3, located downstream of the McCall Glacier-A in the McCall Area. Soil pit was dug downstream from M1. The deepest ash deposit was Mt. St. Helens W aged at 1480 AD. UTM location: Easting 620594, Northing 5154049. 


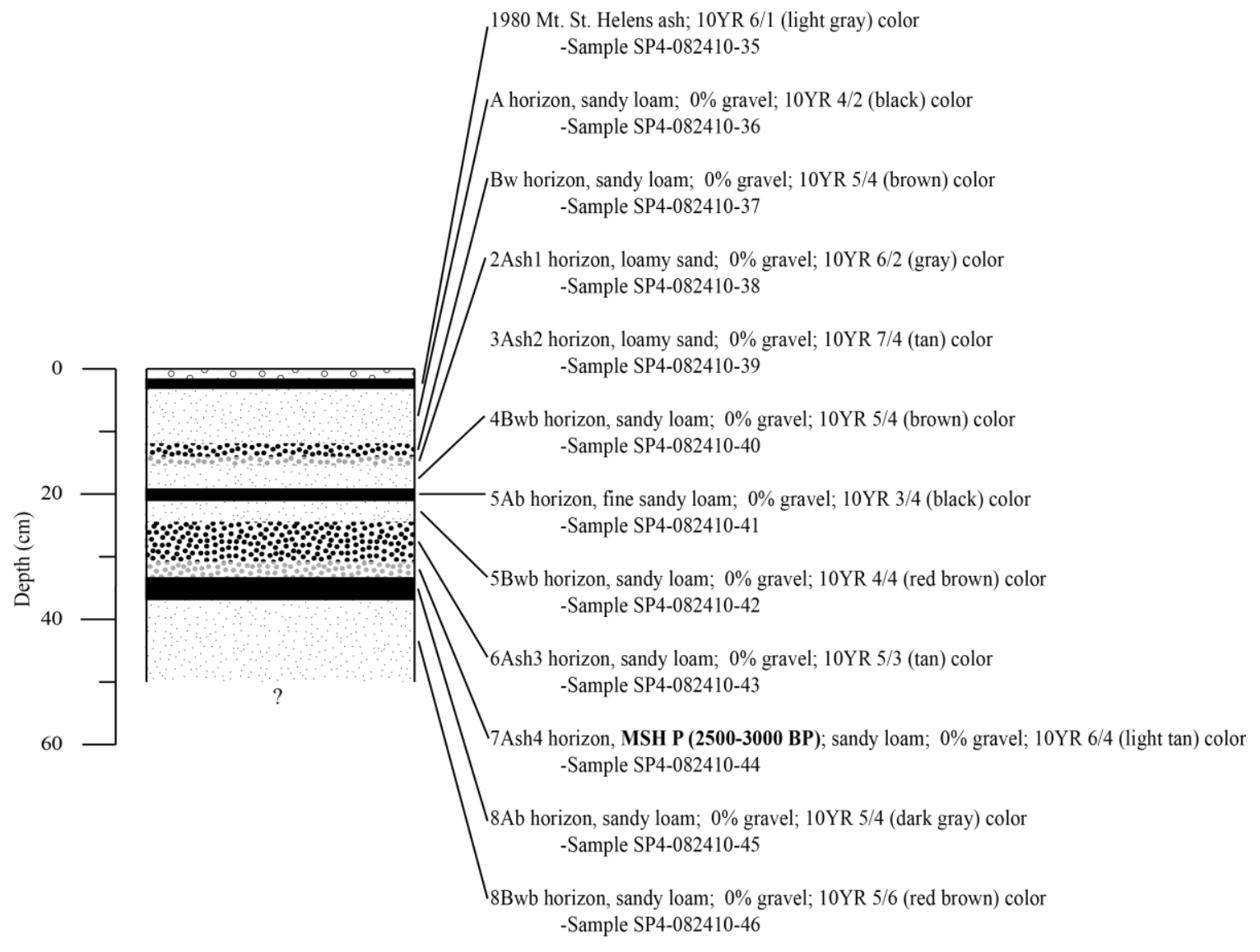

Figure A-5: Stratigraphic cross section of SP4, located on an ancient landslide deposited in a cirque in the Snowgrass Flats Area. The deepest ash deposit was the Mt. St. Helens P, aged between 25003000 yr. BP. UTM location: Easting 619462, Northing 5149917. 


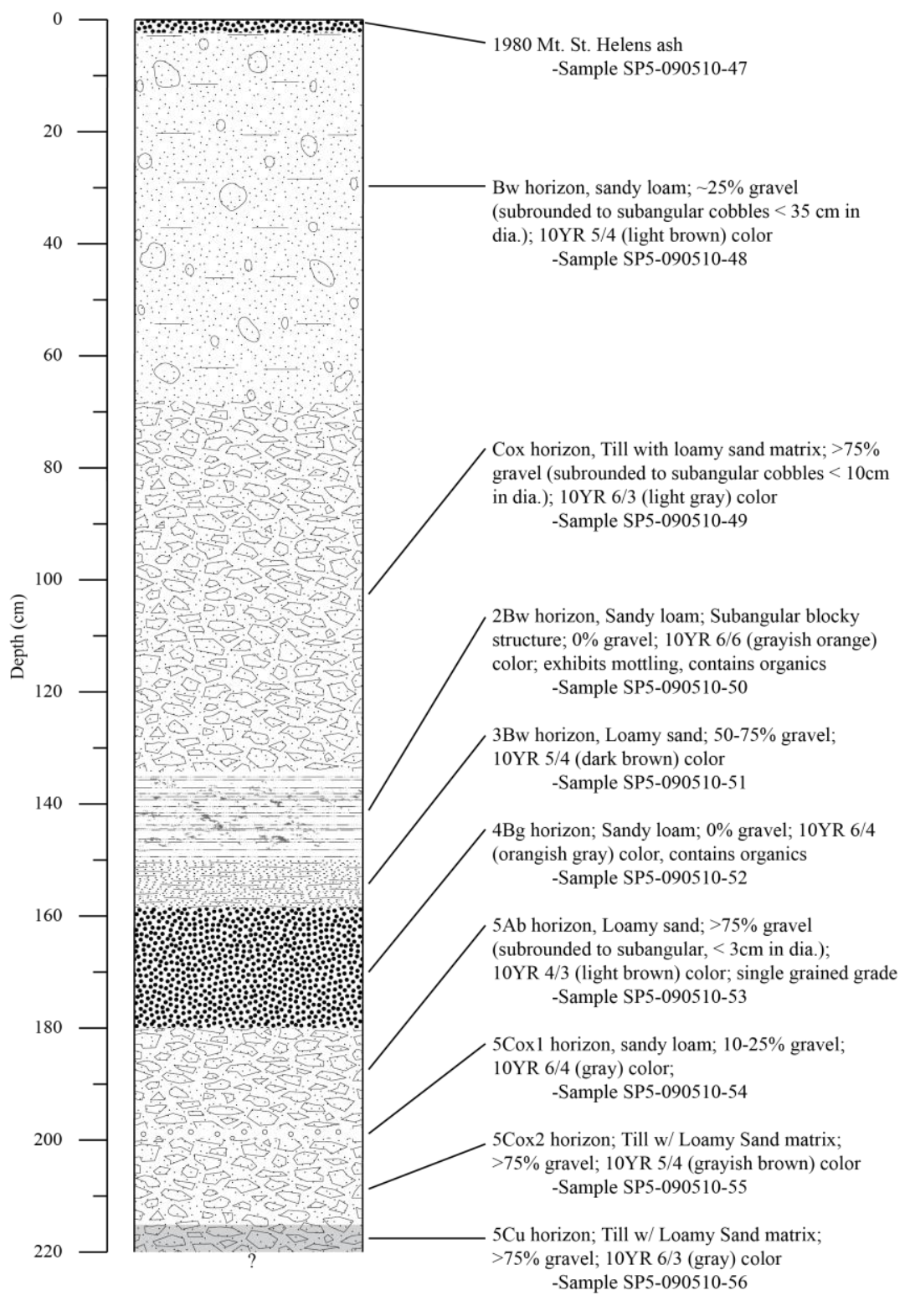

Figure A-6: Stratigraphic cross section of SP5, located downstream of the McCall Glacier-A in the McCall Area. Soil pit was dug at the foot of the proximal slope of M1. UTM location: Easting 620511, Northing 5153923. 


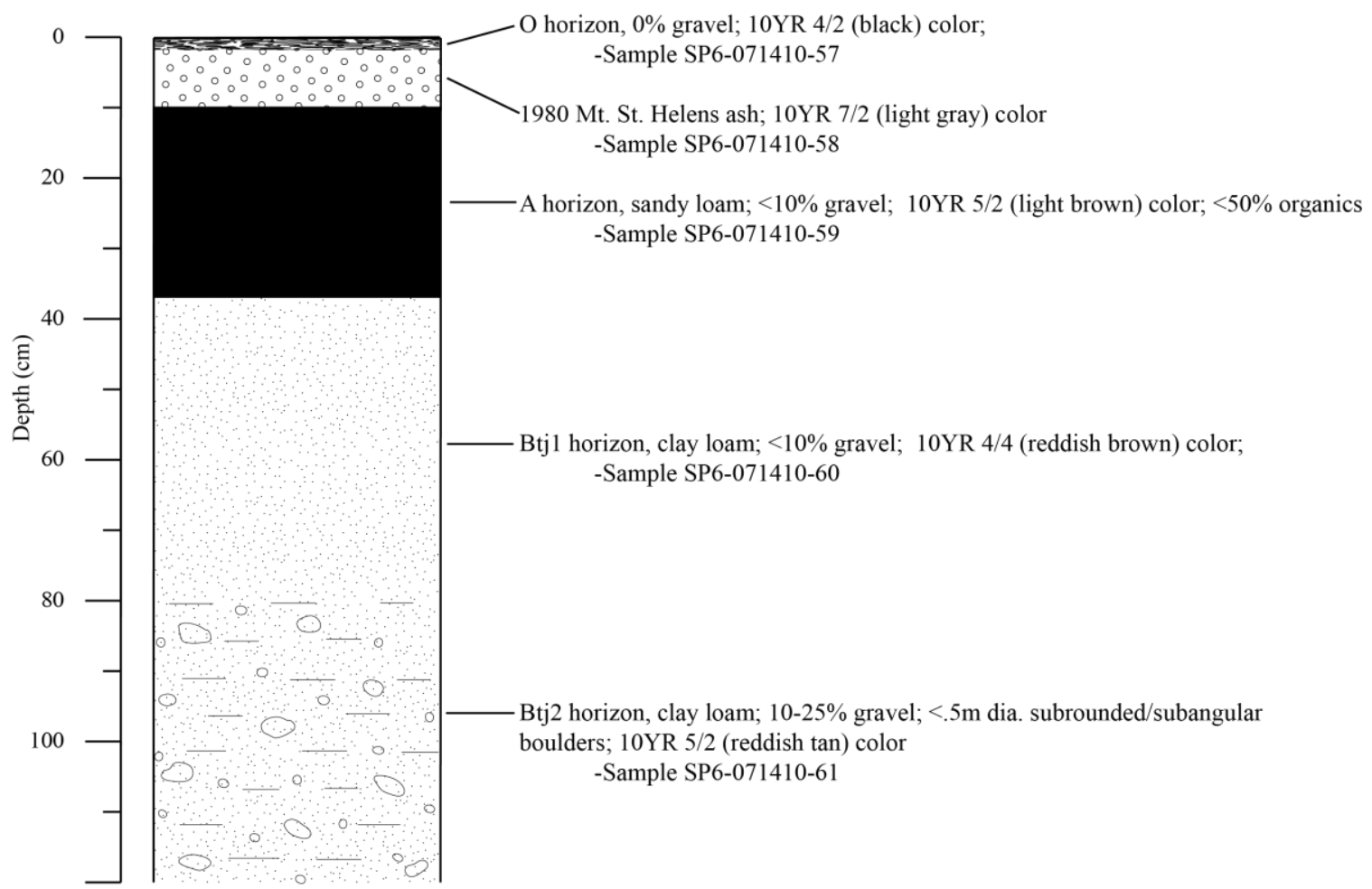

Figure A-7: Stratigraphic cross section of SP6, located near the dam on the eastern shore of Rimrock Lake. Soil pit was dug on the crest of M34. UTM location: Easting 643263, Northing 5168241. 


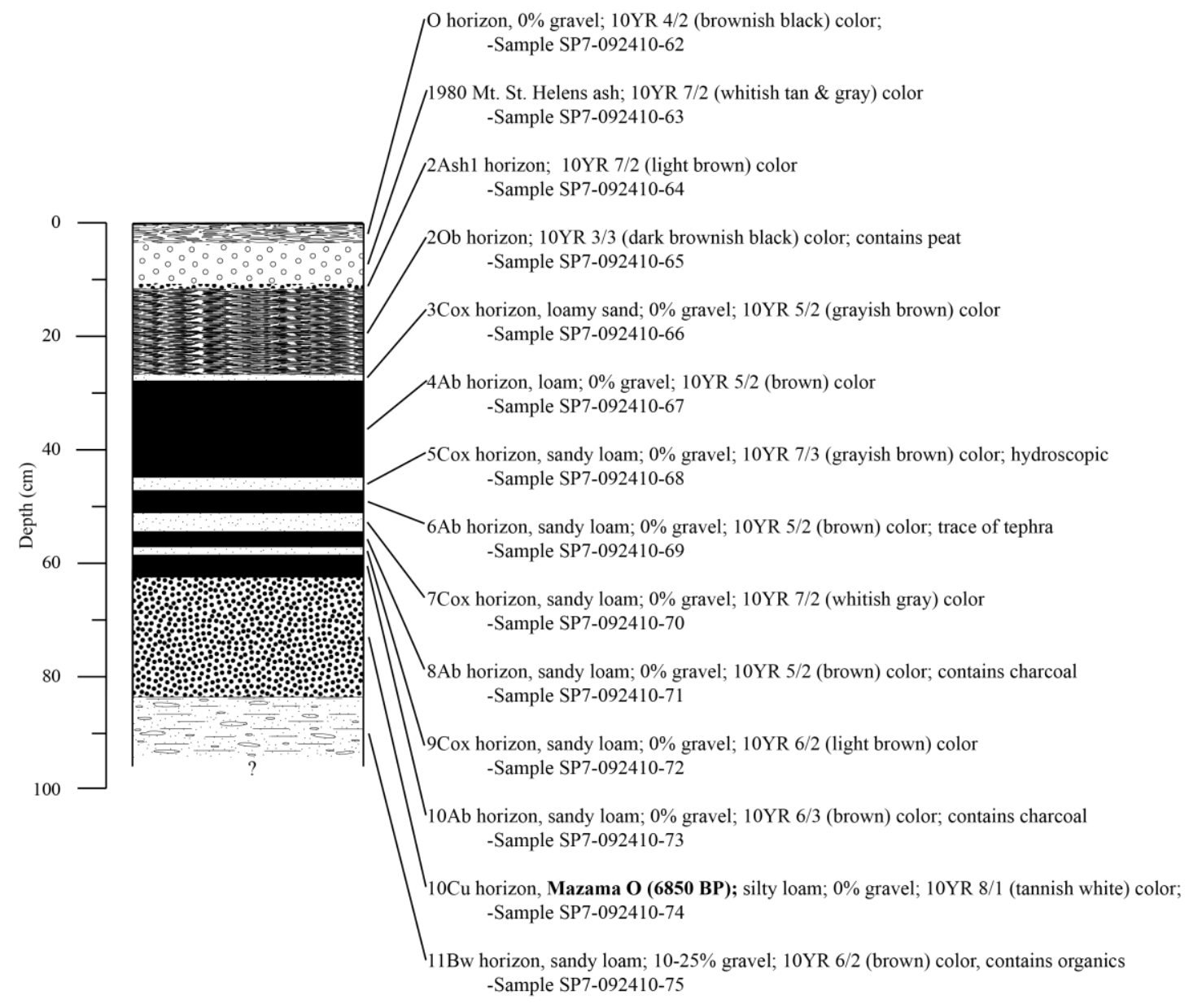

Figure A-8: Stratigraphic cross section of SP7, located downstream from Goat Lake in the Snowgrass Flats Area. Soil pit was dug in a meadow containing Mt. Mazama $O$ ash erupted 6850 yr. BP. UTM location: Easting 615589, Northing 5149417. 


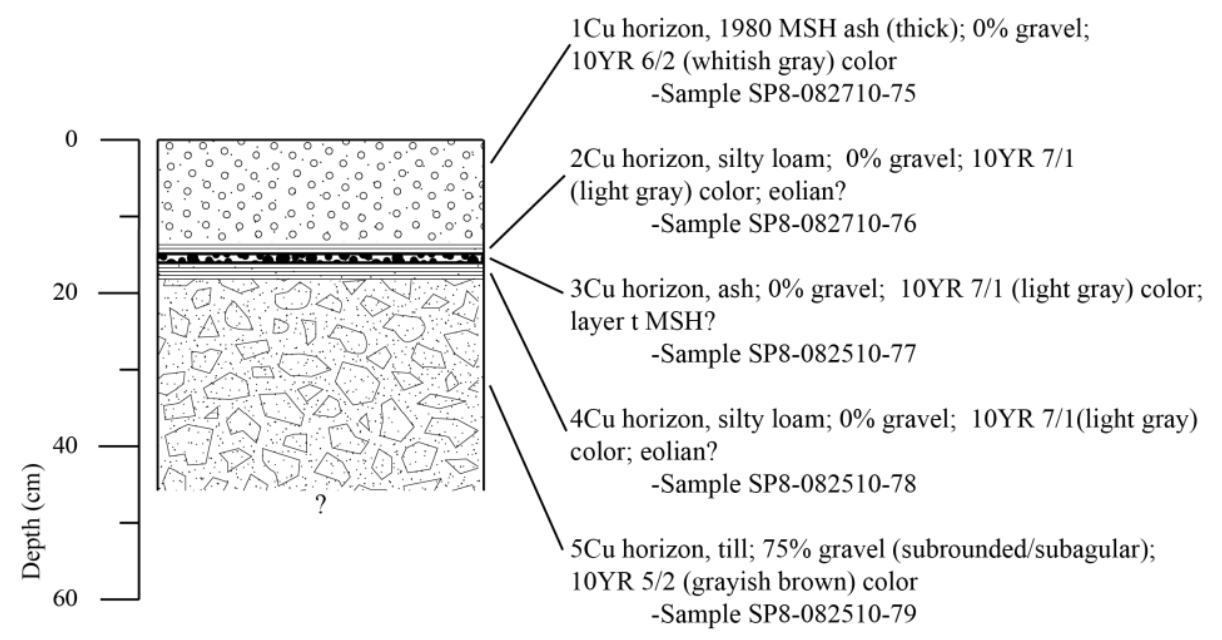

Figure A-9: Stratigraphic cross section of SP8, located next to Goat Lake in the Snowgrass Flats Area. Soil pit was dug on the terminal moraine M24. UTM location: Easting 616182, Northing 5152959.

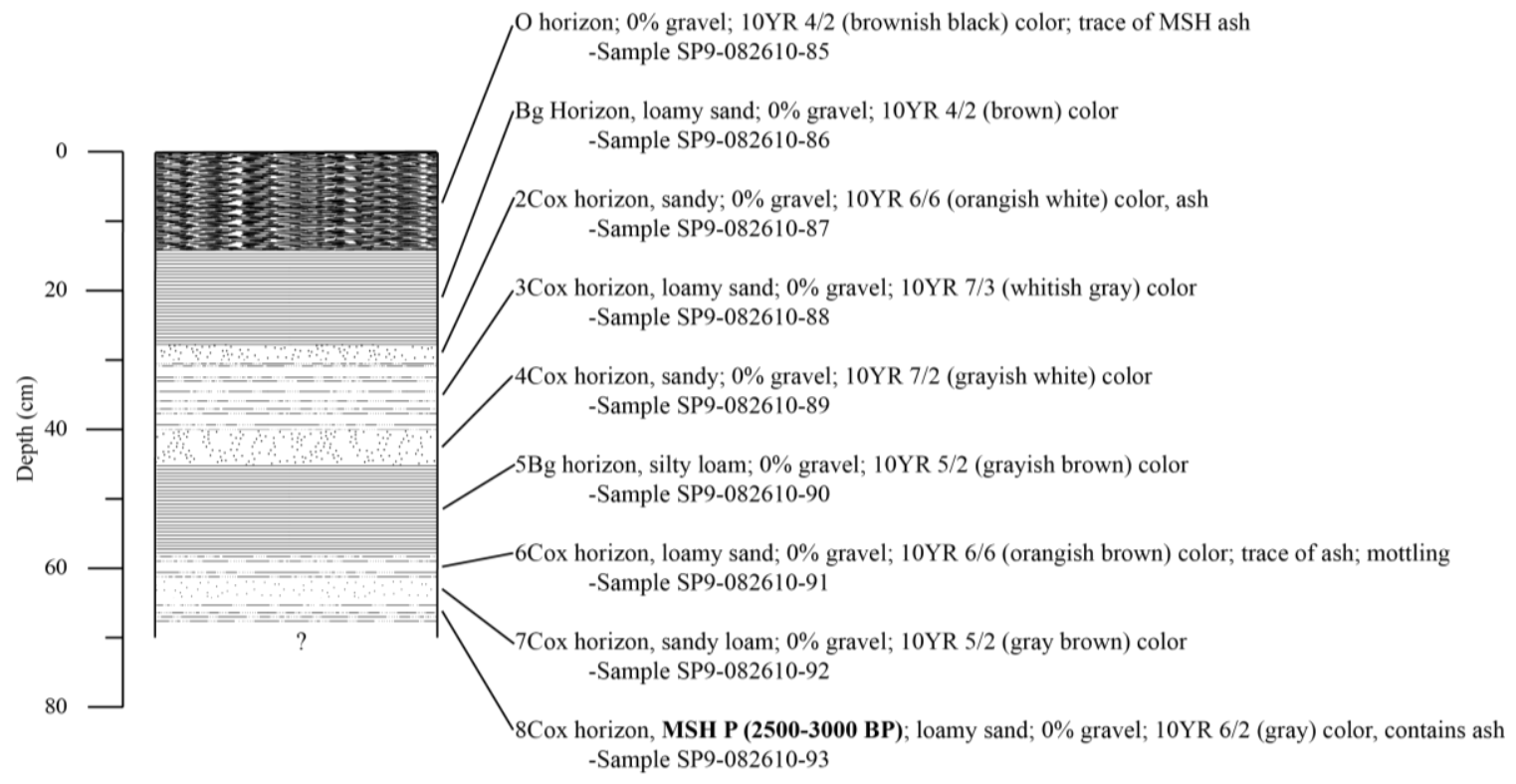

Figure A-10: Stratigraphic cross section of SP9, located on the southern slope of the Goat Rocks highest peaks in the Snowgrass Flats Area. Soil pit was dug in a meadow. The deepest ash deposit was the Mt. St. Helens P, aged between 2500-3000 yr. BP. UTM location: Easting 617874, Northing 5149828. 


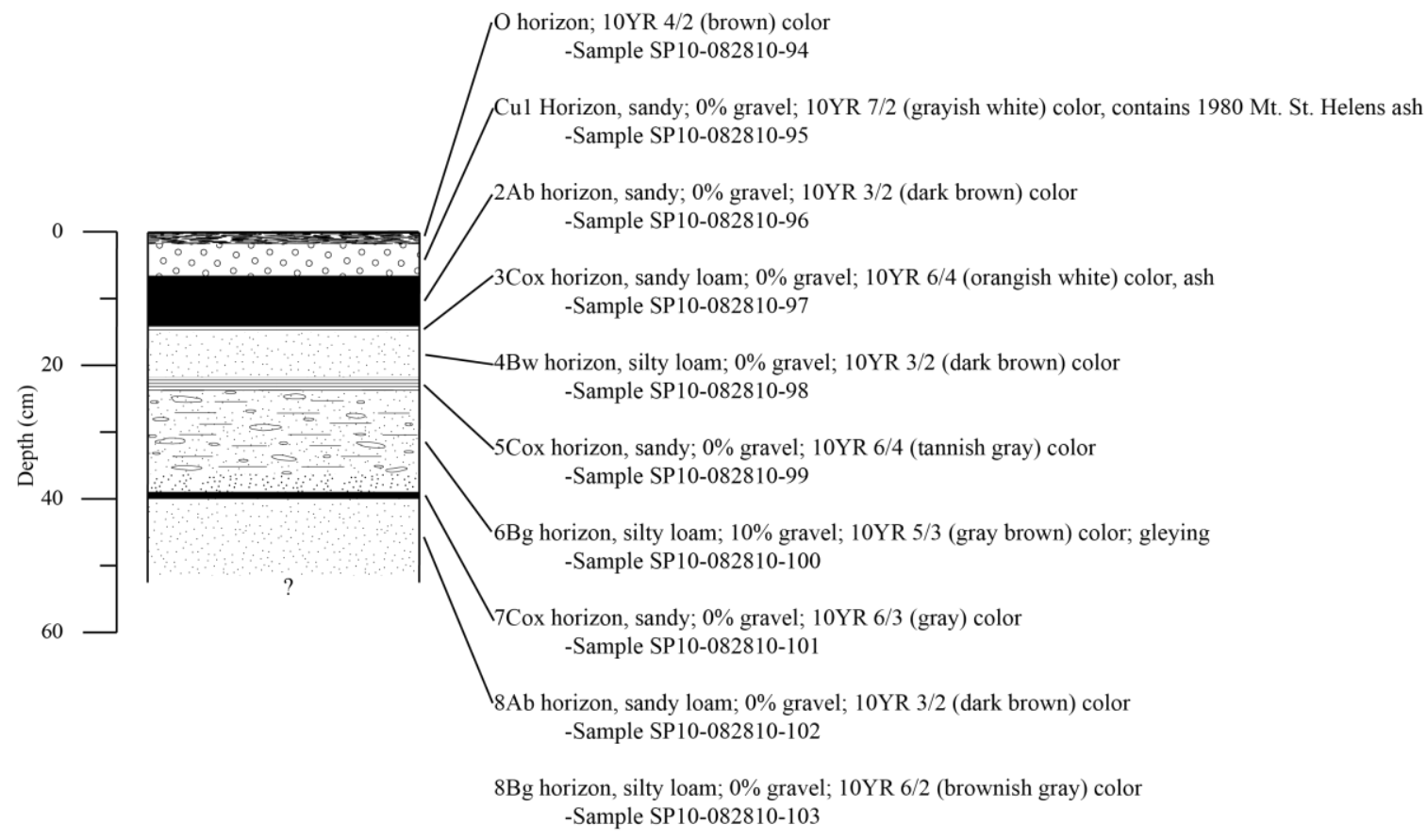

Figure A-11: Stratigraphic cross section of SP10, located on a southeastern slope of the Goat Rocks highest peaks in the Snowgrass Flats Area. Soil pit was dug in a meadow. UTM location: Easting 621030, Northing 5145760. 


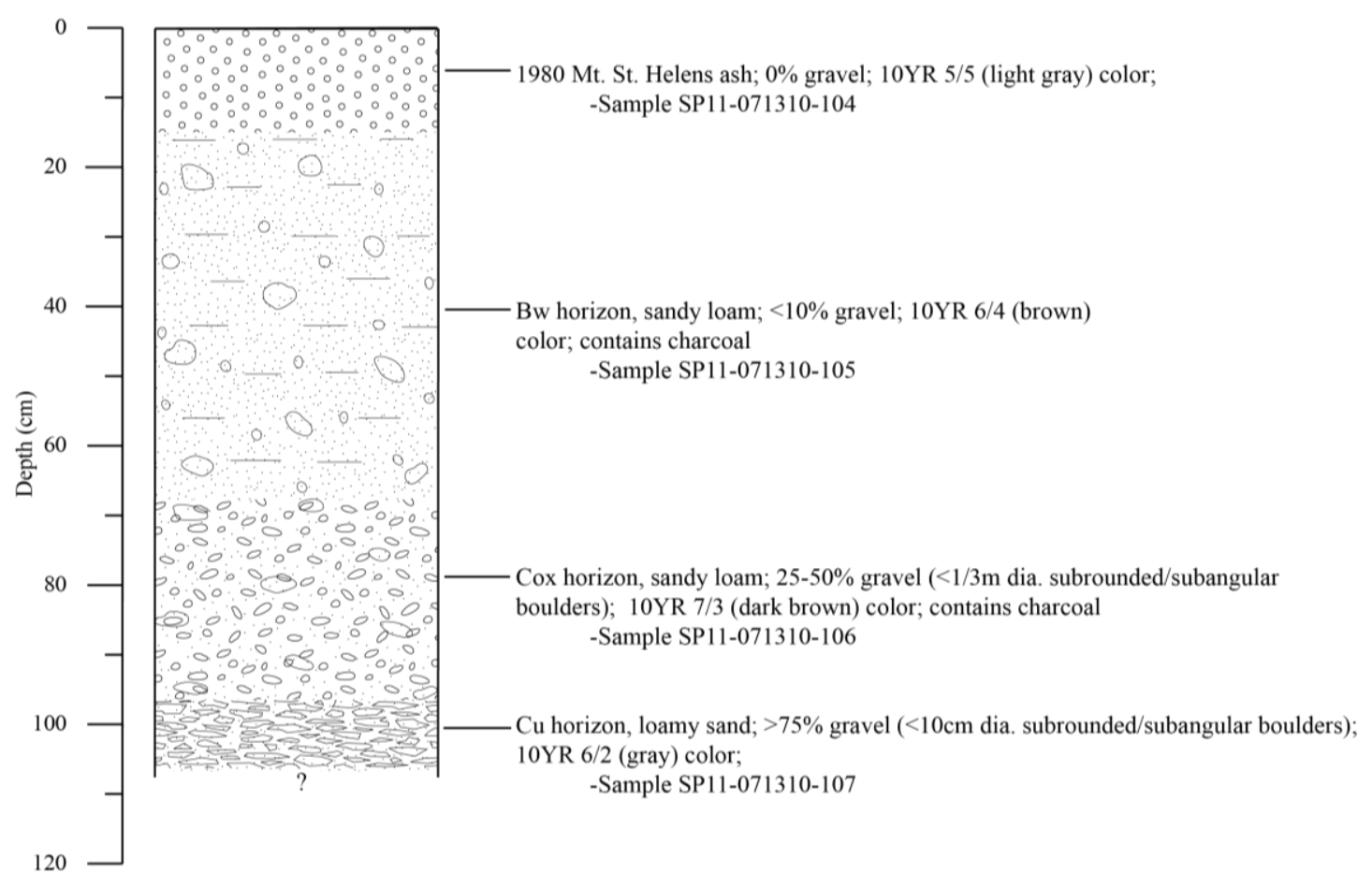

Figure A-12: Stratigraphic cross section of SP11, located near the northwestern shore of Rimrock Lake in a meadow built on glacial drift. UTM location: Easting 633420, Northing 5167356. 


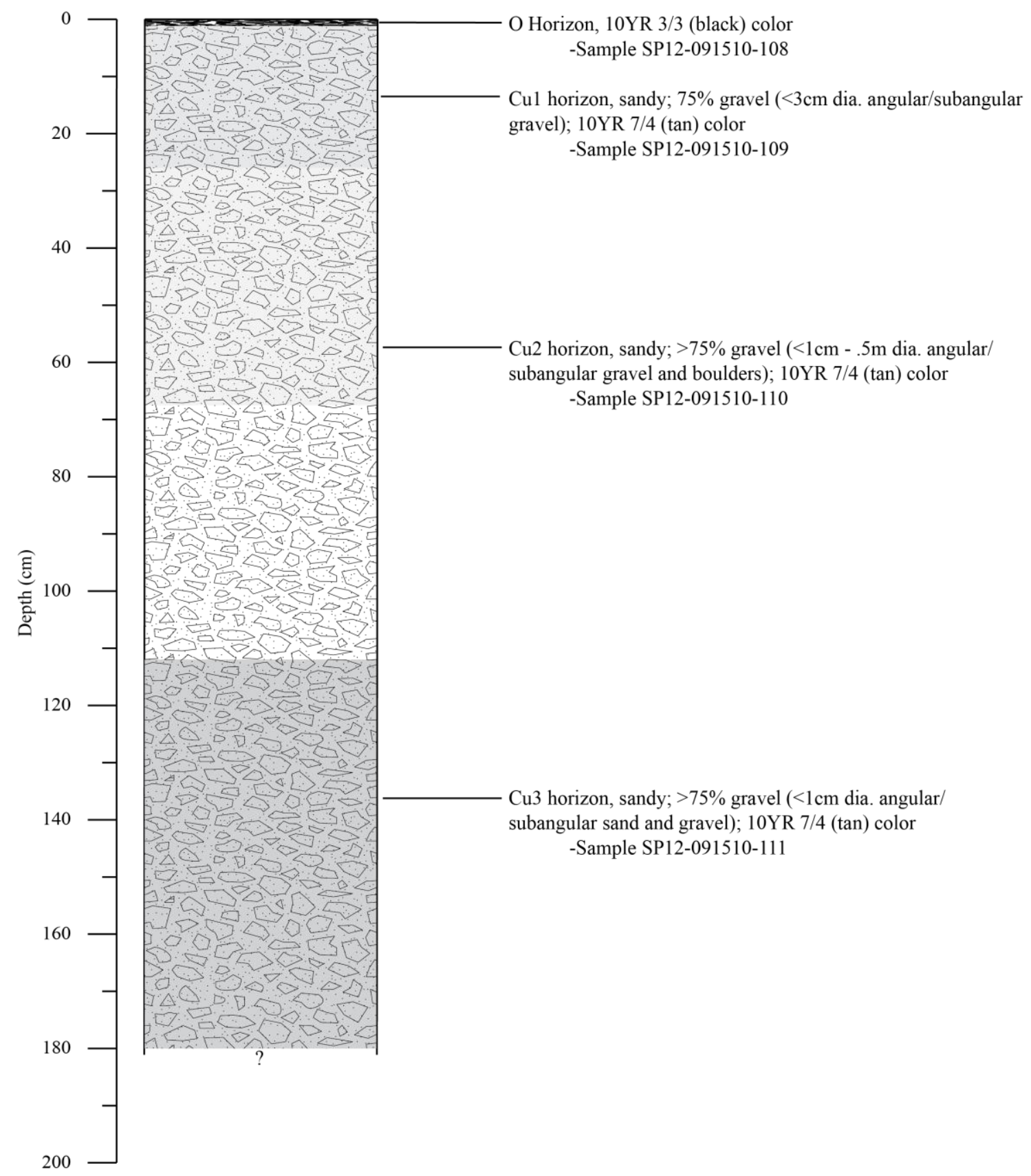

Figure A-13: Stratigraphic cross section of SP12, located in the eastern portion of the Conrad Area on debris flow terrain. SP12 was dug into the cut bank of a small stream. UTM location: Easting 627097, Northing 5151428. 


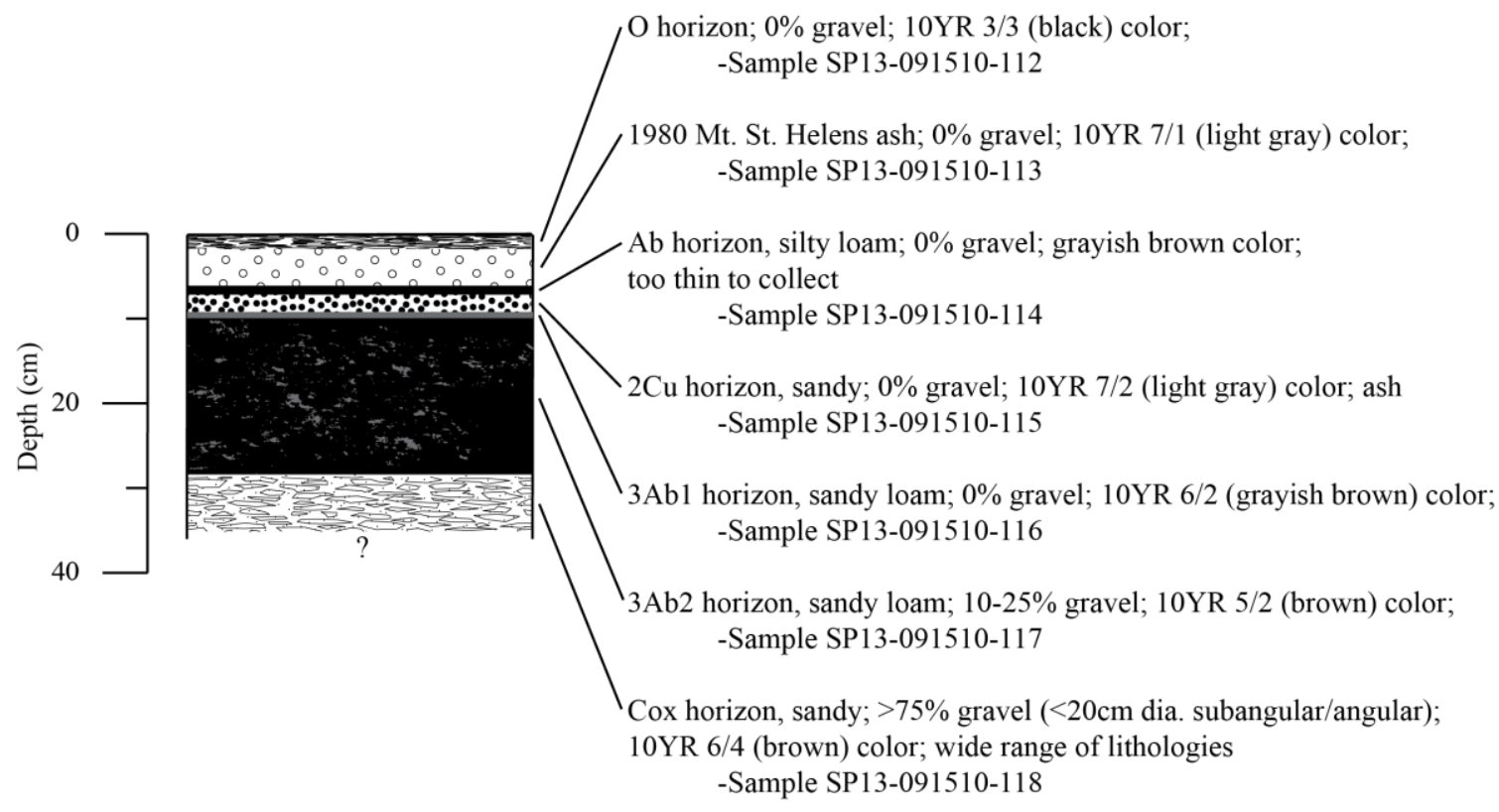

Figure A-14: Stratigraphic cross section of SP13, located in the eastern portion of the Conrad Area. Soil pit was dug on hummocky terrain interpreted to be debris flow deposits. UTM location: Easting 626834, Northing 5151227.

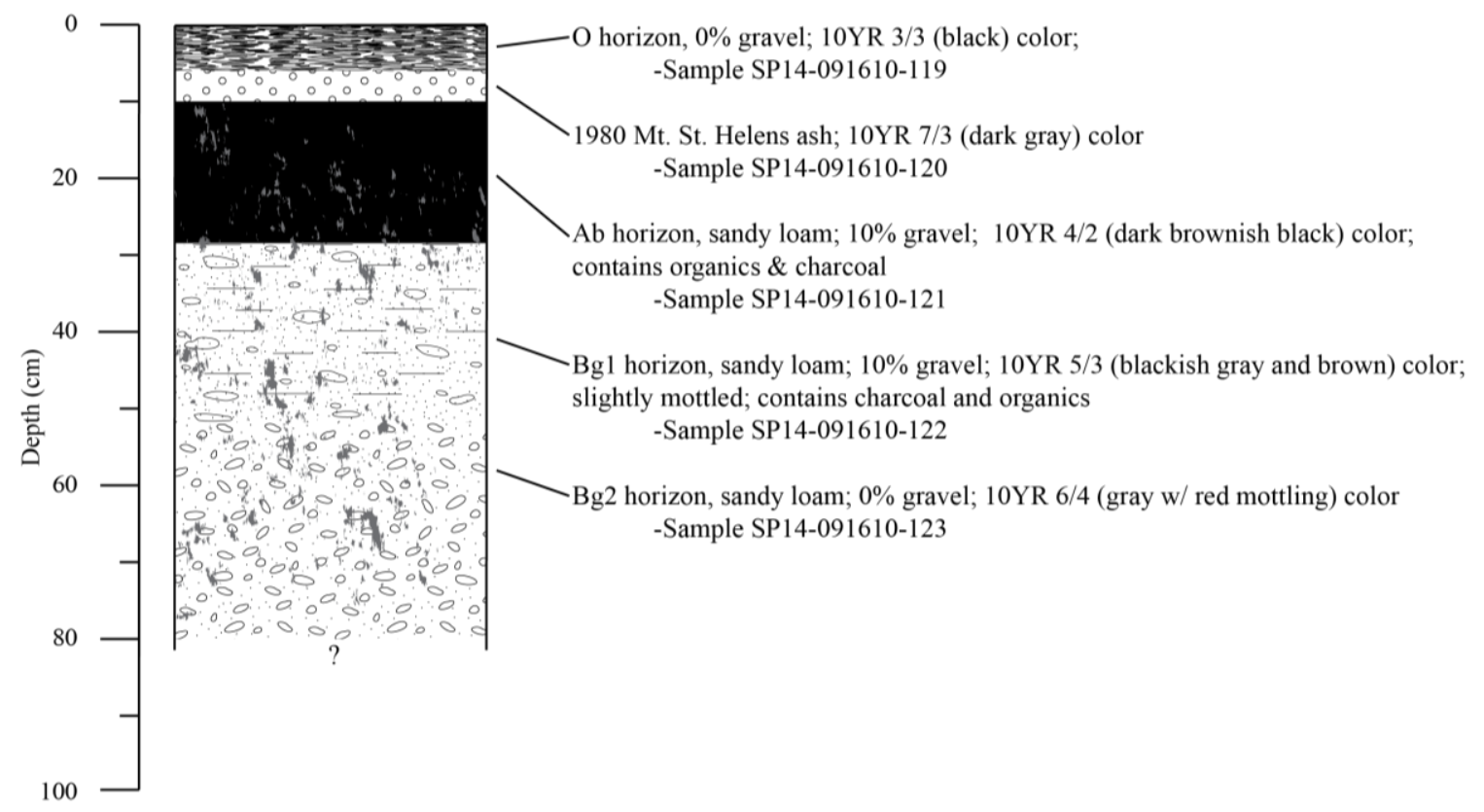

Figure A-15: Stratigraphic cross section of SP14, located in the eastern portion of the Conrad Area. Soil pit was dug in a meadow near hummocky terrain interpreted to be debris flow deposits. UTM location: Easting 627636, Northing 5151010. 


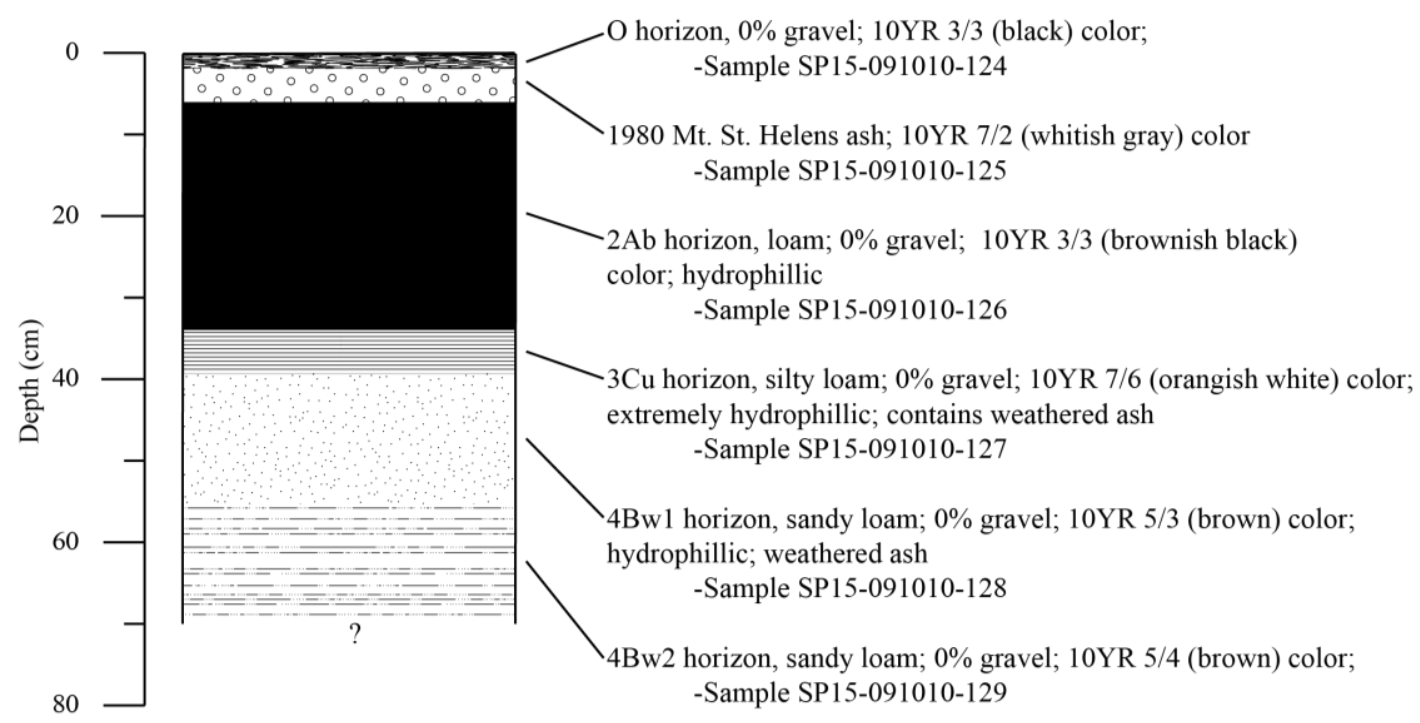

Figure A-16: Stratigraphic cross section of SP15, located downstream from the Meade Glacier in the Conrad Area. Soil pit was dug in a meadow built on glacial drift. UTM location: Easting 624234, Northing 5149796. 


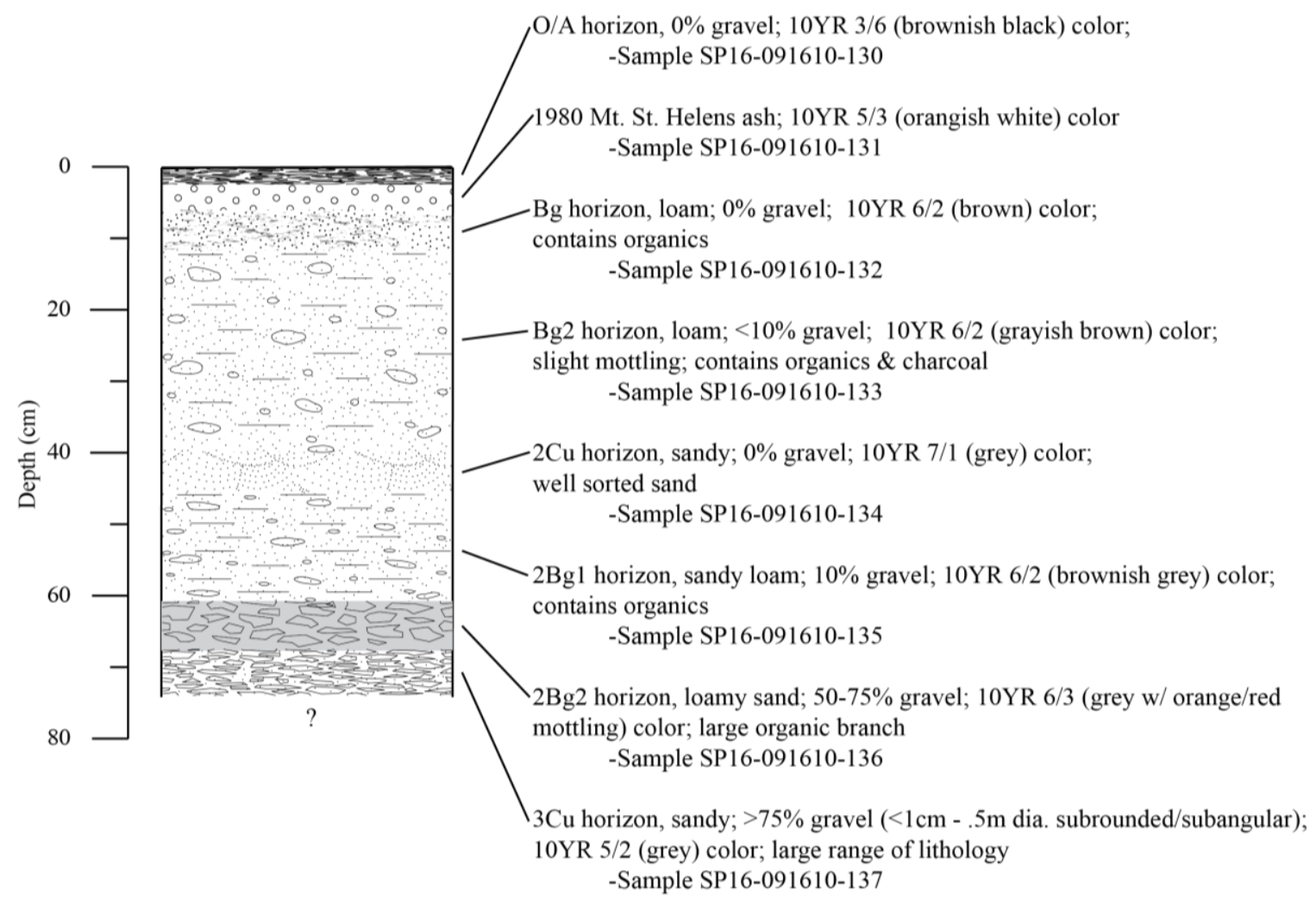

Figure A-17: Stratigraphic cross section of SP16, located downstream from the Meade Glacier in the Conrad Area. Soil pit was dug into a cutbank of a small stream near hummocky terrain interpreted to be debris flow deposits. UTM location: Easting 627668, Northing 5150936. 


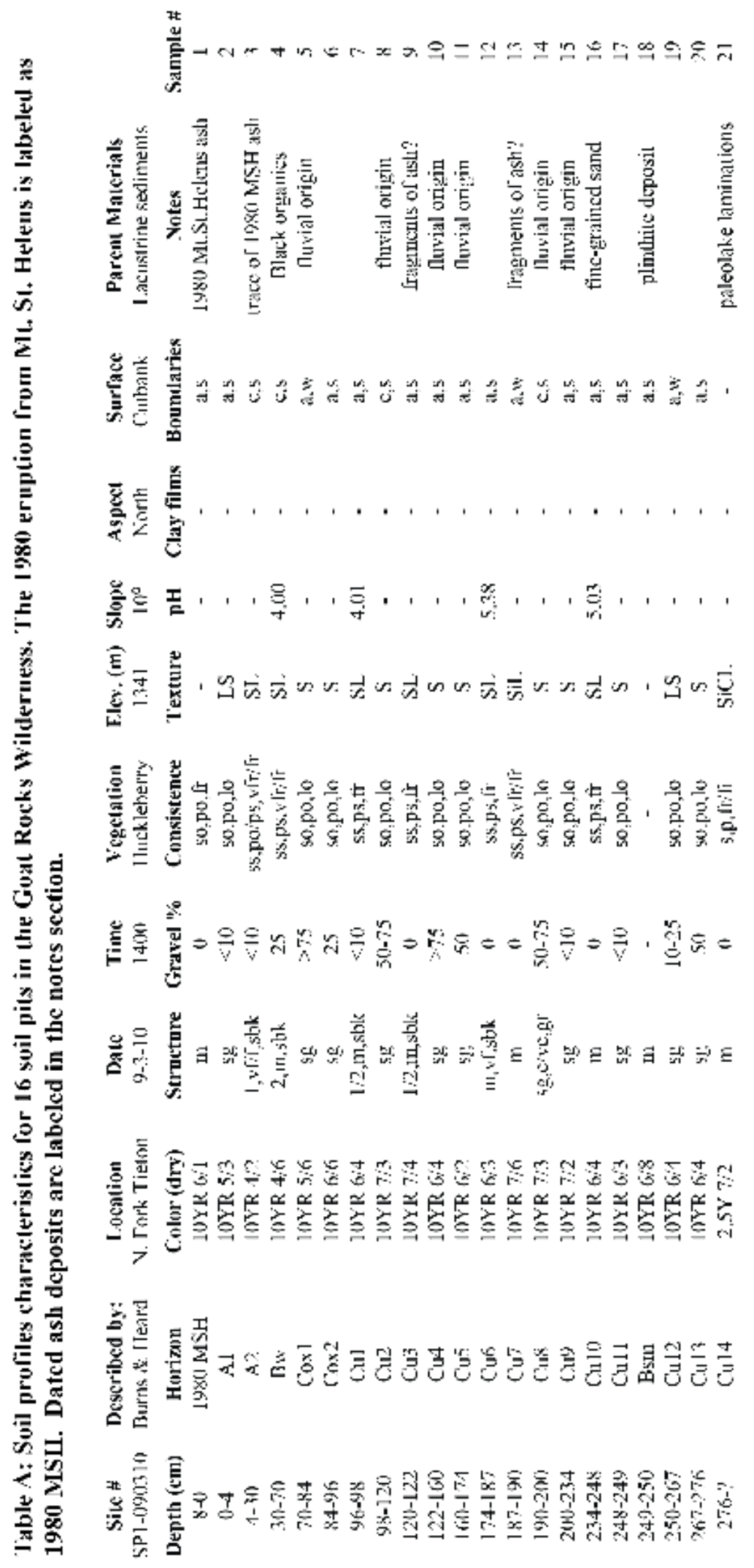




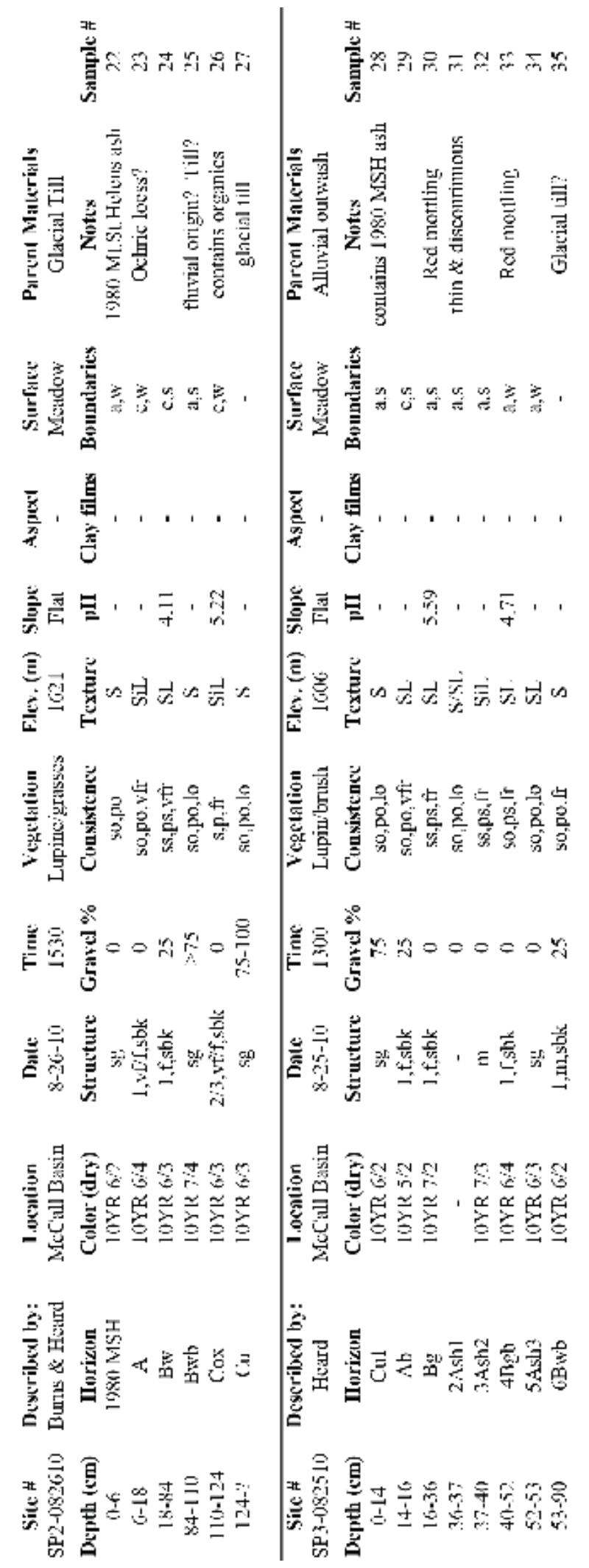




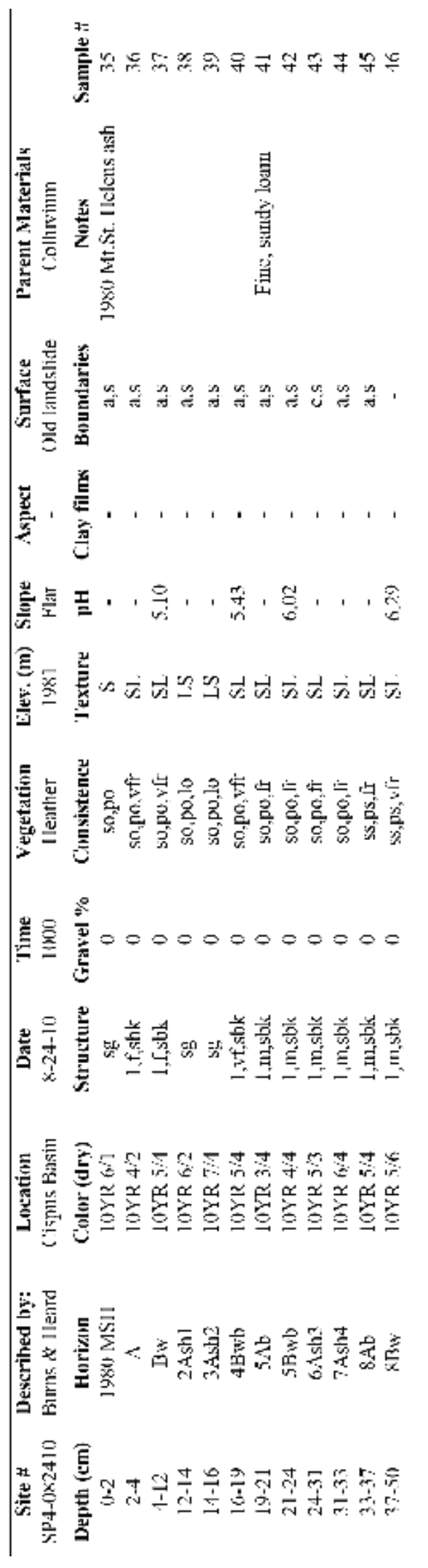

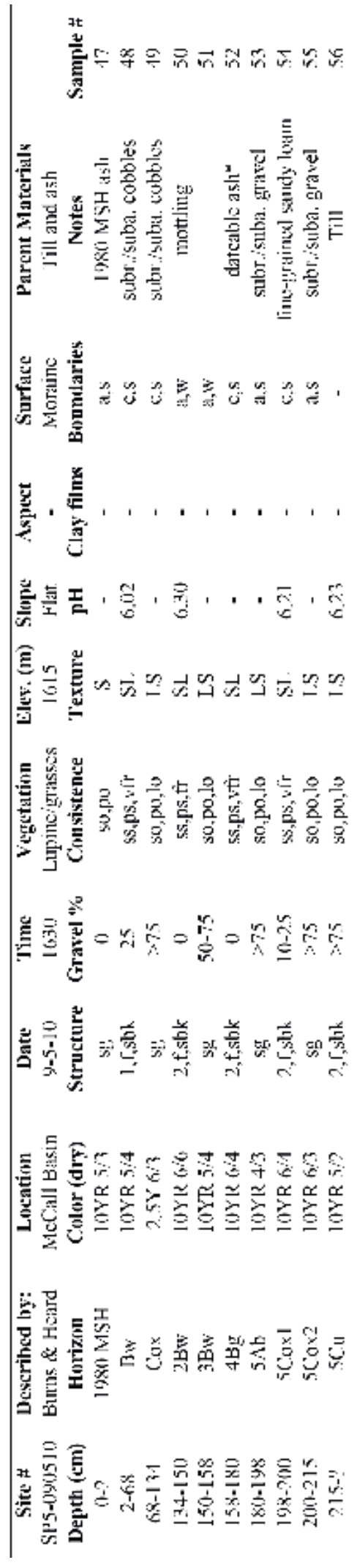




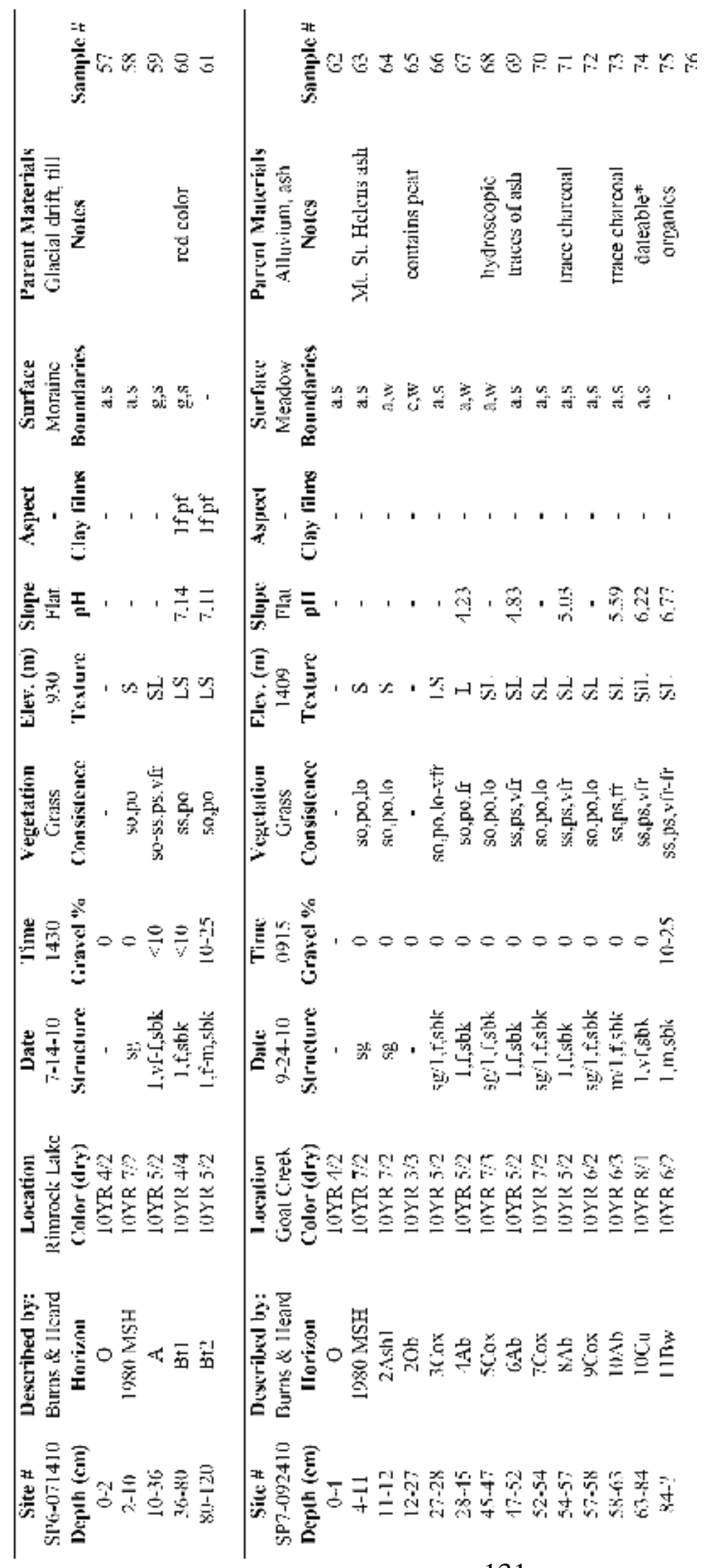




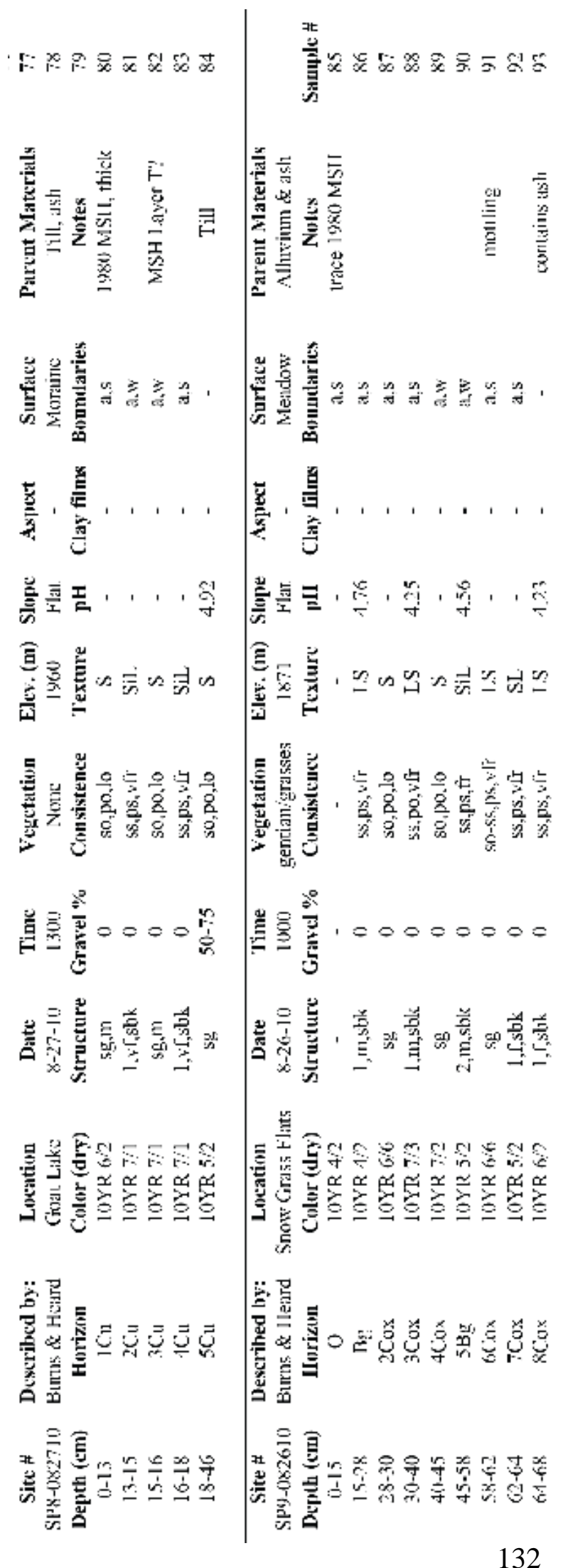




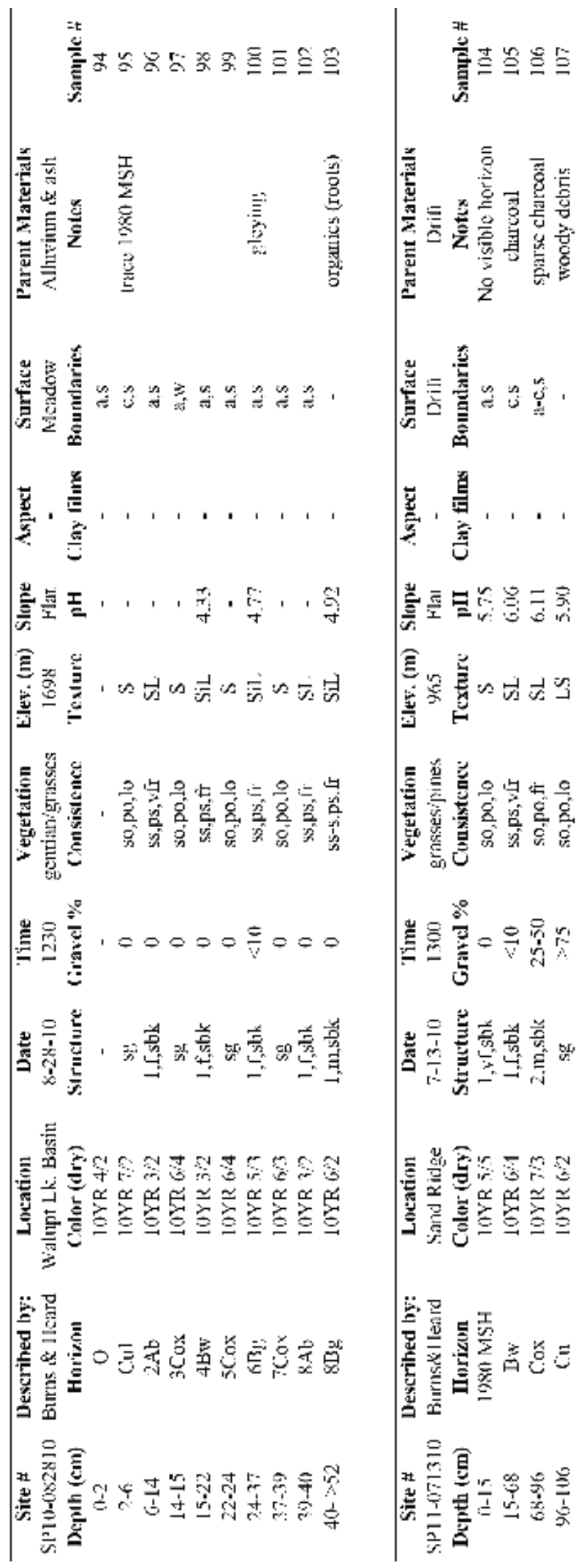




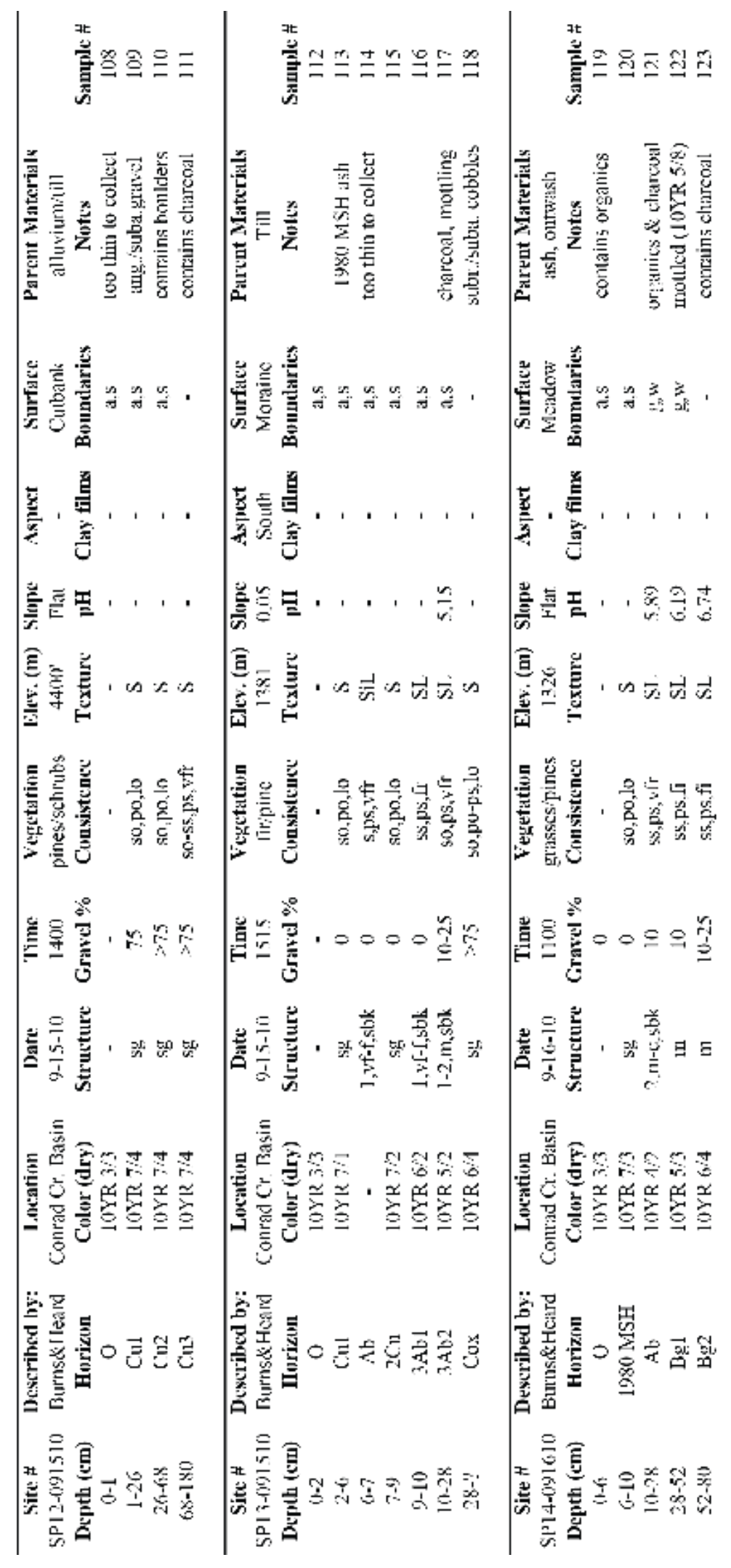




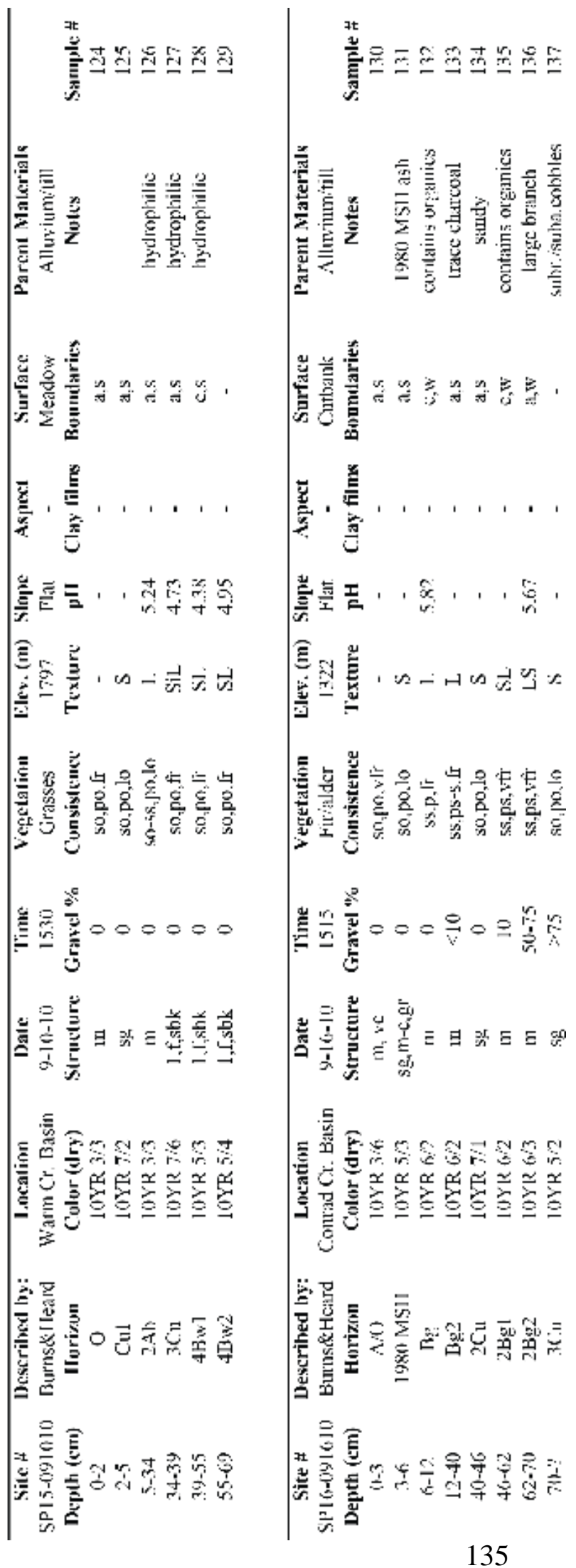




\section{Appendix B: Moraine measurements}

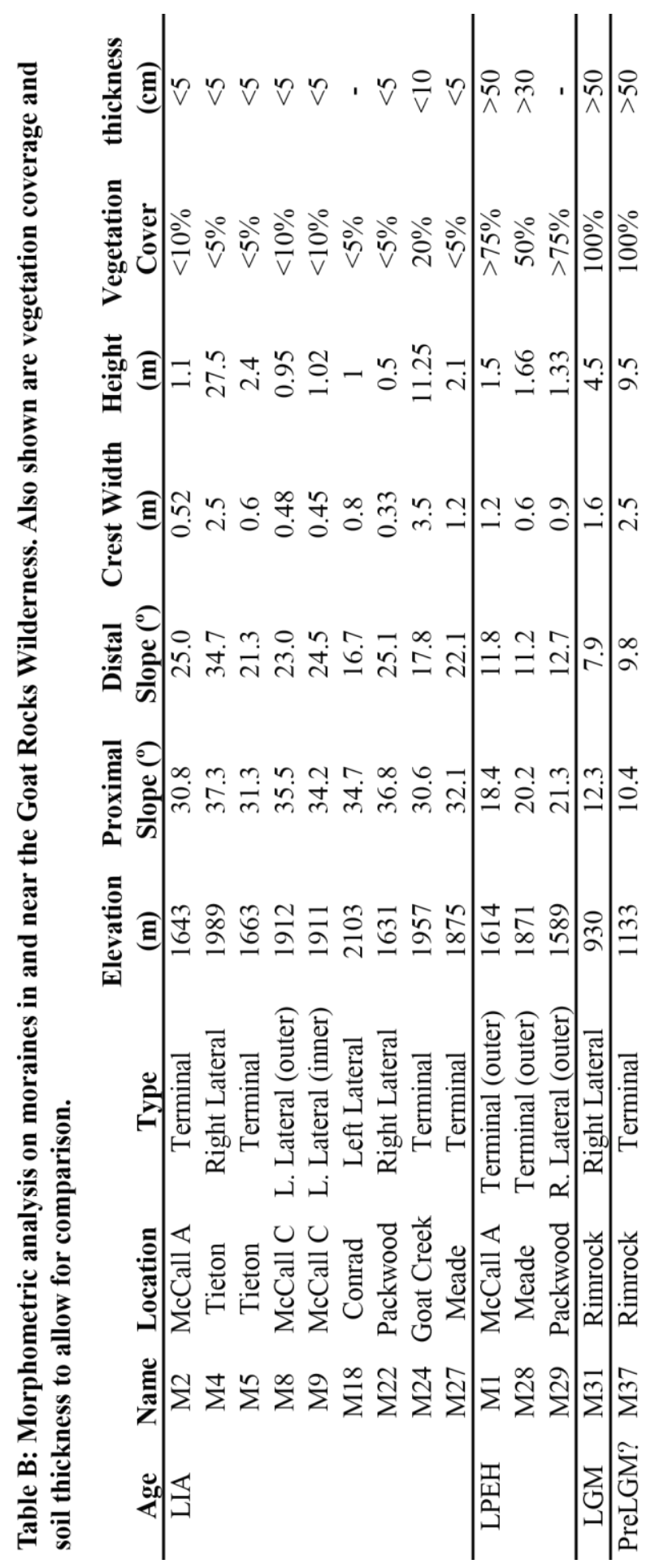




\section{Appendix C: Lichen measurements and ages}

Table C: Lichen measurements for the 20 lichen sites in the Goat Rocks Wilderness. Lichen locations are in UTM. Aspect directions are downslope directions of the substrates.

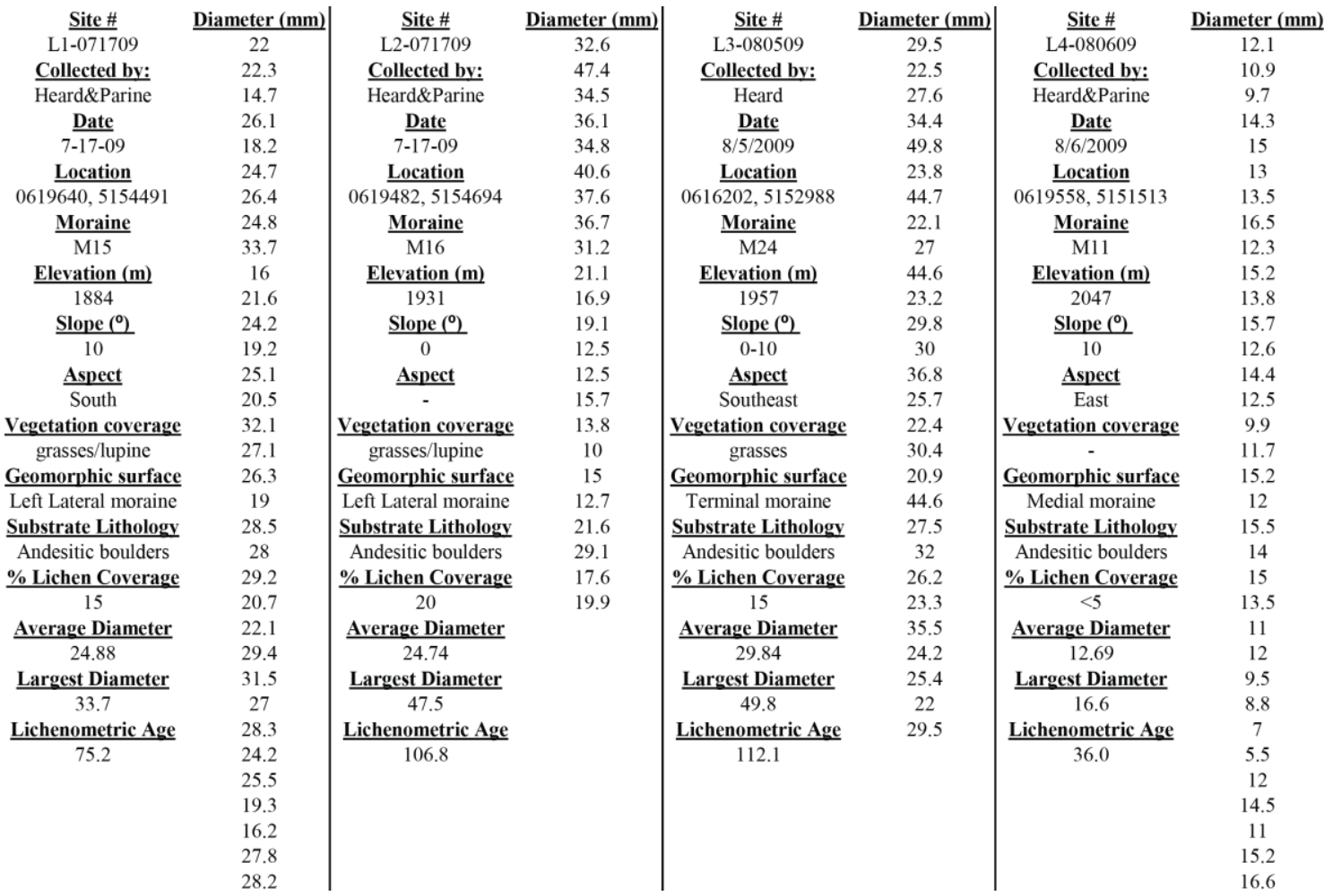




\begin{tabular}{|c|c|c|c|c|c|c|c|}
\hline Site\# & Diameter (mm) & Site \# & Diameter (mm) & $\underline{\text { Site \# }}$ & Diameter $(\mathrm{mm})$ & $\underline{\text { Site \# }}$ & Diameter $(\mathrm{mm})$ \\
\hline L5-080609 & 34.4 & L6-071709 & 31.4 & L7-081609 & 6.6 & L8-081809 & 29 \\
\hline Collected by: & 29.1 & Collected by: & 24.1 & Collected by: & 3.5 & Collected by: & 28.2 \\
\hline Heard\&Parine & 25.5 & Heard & 27.5 & Heard\&Schene & 7.9 & Heard & 29.5 \\
\hline Date & 25 & $\underline{\text { Date }}$ & 35.9 & Date & 3.5 & Date & 21.8 \\
\hline $8 / 6 / 2009$ & 16.3 & $8 / 15 / 2009$ & 31.6 & $8 / 16 / 2009$ & 2.6 & $8 / 18 / 2009$ & 27.9 \\
\hline Location & 23.7 & Location & 20.1 & Location & 14.8 & Location (UTM) & 28.1 \\
\hline 0620272,5151826 & 19.6 & $0619 \overline{513,5154702}$ & 30.5 & 0620272,5151146 & 9.1 & 0620496,5151752 & 39.4 \\
\hline Moraine & 16.4 & Moraine & 14.8 & Moraine & 8 & Moraine & 35.2 \\
\hline M9 & 17.2 & M17 & 46.3 & M12 & 3.8 & M13 & 34.2 \\
\hline Elevation $(\mathrm{m})$ & 15.8 & Elevation (m) & 40 & Elevation (m) & 5.6 & Elevation $(\mathrm{m})$ & 31.3 \\
\hline 1909 & 19 & 1916 & 19.5 & 1981 & 4 & 1826 & 23.8 \\
\hline Slope $\left(0^{\circ}\right)$ & 25.1 & Slope $\left({ }^{\circ}\right)$ & 24.5 & Slope $\left({ }^{\circ}\right)$ & 4 & Slope $\left({ }^{\circ}\right)$ & 24.9 \\
\hline $0-10$ & 25 & 10 & 34 & $15-25$ & 4.3 & 10 & 40.6 \\
\hline Aspect & 23.9 & Aspect & 37.7 & Aspect & 4.1 & Aspect & 48.6 \\
\hline South & 23.4 & Southwest & 22.7 & North & 5.3 & South & 31.5 \\
\hline Vegetation coverage & 19.6 & Vegetation coverage & 26.2 & Vegetation coverage & 7.1 & Vegetation coverage & 22.4 \\
\hline grasses/shrubs & 20 & grasses/lupine & 21.6 & - & 4.4 & - & 28.2 \\
\hline Geomorphic surface & 13 & Geomorphic surface & 32.7 & Geomorphic surface & 5 & Geomorphic surface & 27.4 \\
\hline $\begin{array}{l}\text { Left lateral moraine } \\
\end{array}$ & 15 & Left lateral moraine & 32.4 & $\overline{\text { Left lateral moraine }}$ & 4.1 & $\overline{\text { Left lateral moraine }}$ & 19.7 \\
\hline Substrate Lithology & 22.8 & $\underline{\text { Substrate Lithology }}$ & 26.8 & Substrate Lithology & 4.2 & $\underline{\text { Substrate Lithology }}$ & 23.6 \\
\hline Andesitic boulders & 14.2 & Andesitic boulders & 17.4 & Andesitic boulders & 3.8 & Andesitic boulders & 21.2 \\
\hline \% Lichen Coverage & 16.6 & \% Lichen Coverage & 19.1 & \% Lichen Coverage & 8.6 & \% Lichen Coverage & 22.1 \\
\hline 10 & 24 & 20 & 42 & $<5$ & 8.7 & $0-35$ & 36.1 \\
\hline Average Diameter & 20.4 & Average Diameter & 28 & Average Diameter & 7.3 & Average Diameter & 21 \\
\hline 21.40 & 24 & 28.83 & 34 & 9.84 & 7.9 & 31.25 & 22.5 \\
\hline Largest Diameter & 25.5 & Largest Diameter & & Largest Diameter & 6.5 & Largest Diameter & 50.5 \\
\hline 34.4 & 22.5 & 46.3 & & 25.1 & 7 & 55.2 & 40.5 \\
\hline Lichenometric Age & 28 & Lichenometric Age & & Lichenometric Age & 5.4 & Lichenometric Age & 31 \\
\hline 76.8 & 19.5 & 104.1 & & 55.5 & 6.2 & 124.5 & 42 \\
\hline & 17.5 & & & & 13.6 & & 55.2 \\
\hline & & & & & 9 & & \\
\hline & & & & & 5.5 & & \\
\hline & & & & & 8 & & \\
\hline & & & & & 10.5 & & \\
\hline & & & & & 18.1 & & \\
\hline & & & & & 7.8 & & \\
\hline & & & & & 13.3 & & \\
\hline & & & & & 15.3 & & \\
\hline & & & & & 23.3 & & \\
\hline & & & & & 10.1 & & \\
\hline & & & & & 18 & & \\
\hline & & & & & 15 & & \\
\hline & & & & & 12.5 & & \\
\hline & & & & & 16.1 & & \\
\hline & & & & & 25.1 & & \\
\hline & & & & & 14.5 & & \\
\hline & & & & & 12.4 & & \\
\hline & & & & & 17.9 & & \\
\hline & & & & & 11.5 & & \\
\hline & & & & & 16.8 & & \\
\hline & & & & & 16.1 & & \\
\hline & & & & & 16.9 & & \\
\hline & & & & & 14.2 & & \\
\hline & & & & & 12.2 & & \\
\hline & & & & & 18.5 & & \\
\hline
\end{tabular}




\begin{tabular}{|c|c|c|c|c|c|c|c|}
\hline$\underline{\text { Site \# }}$ & Diameter (mm) & Site \# & Diameter $(\mathrm{mm})$ & Site \# & Diameter (mm) & Site \# & Diameter (mm) \\
\hline L9-081809 & 30.4 & $\mathrm{~L} 1 \overline{0-081909}$ & 10.9 & L11 $\overline{1-081909}$ & 22.4 & $\mathrm{~L} 1 \overline{2-092810}$ & 18.4 \\
\hline Collected bv: & 19.6 & Collected bv: & 7.5 & Collected by: & 17.5 & Collected bv: & 29.1 \\
\hline Heard & 21 & $\overline{\text { Heard\&Parine }}$ & 7 & $\overline{\text { Heard\&Parine }}$ & 12.2 & Heard & 34 \\
\hline Date & 22 & Date & 10.3 & Date & 20.7 & Date & 38 \\
\hline $8 / \overline{18 / 2009}$ & 18.5 & $8 / \overline{19 / 2009}$ & 6.9 & $8 / \overline{19 / 2009}$ & 27.6 & $9 / 28 / 2010$ & 42.5 \\
\hline Location (UTM) & 20.3 & Location (UTM) & 9.4 & Location (UTM) & 14.5 & Location (UTM) & 38.9 \\
\hline 0620586,5151611 & 18.5 & 0621916,5150229 & 12.6 & 0621916,5150229 & 34.5 & 0617543,5154008 & 22.5 \\
\hline Moraine & 23.5 & Moraine & 8.8 & Moraine & 30.5 & Moraine & 25.6 \\
\hline $\mathrm{M} 14$ & 31.2 & $\mathrm{M} 18$ & 4.6 & M19 & 19 & M21 & 30.8 \\
\hline Elevation (m) & 22.3 & Elevation (m) & 3.7 & Elevation (m) & 29.1 & Elevation (m) & 31.6 \\
\hline 1792 & 25.8 & 2110 & 10.7 & 1982 & 12.8 & 1347 & 26.9 \\
\hline Slope $\left({ }^{\circ}\right)$ & 20.8 & Slope $\left({ }^{\circ}\right)$ & 4.5 & Slope $\left({ }^{\circ}\right)$ & 18.8 & Slope $\left({ }^{\circ}\right)$ & 37.1 \\
\hline $0-10$ & 25.4 & 15 & 11.3 & 15 & 22.2 & 15 & 41.5 \\
\hline Aspect & 27.9 & Aspect & 6.3 & Aspect & 13.5 & Aspect & 39.2 \\
\hline East/southeast & 35.2 & Northeast & 5.4 & - & 26.9 & North,northwest & 35 \\
\hline Vegetation coverage & 28.6 & Vegetation coverage & 12.4 & Vegetation coverage & 14.2 & Vegetation coverage & 36 \\
\hline- & 21.4 & - & 13.1 & - & 16 & Grasses & 45.5 \\
\hline Geomorphic surface & 24.2 & Geomorphic surface & 13.5 & Geomorphic surface & 12.3 & Geomorphic surface & 51.5 \\
\hline Medial moraine & 21 & Left lateral moraine & 10.1 & Left lateral moraine & 17.1 & Right lateral moraine & 45 \\
\hline Substrate Lithology & 26.6 & $\underline{\text { Substrate Lithology }}$ & 11.5 & Substrate Lithology & 14.8 & $\underline{\text { Substrate Lithology }}$ & 42.5 \\
\hline Andesitic boulders & 26.6 & Andesitic boulders & 14.7 & Andesitic boulders & 15.5 & Andesitic boulders & 37.5 \\
\hline \% Lichen Coverage & 20.5 & \% Lichen Coverage & 11.6 & \% Lichen Coverage & 19 & \% Lichen Coverage & 42 \\
\hline $0-55$ & 26.8 & $<5$ & 10.7 & 10 & 16.1 & $15-20$ & 46.8 \\
\hline Average Diameter & 26.2 & Average Diameter & 9 & Average Diameter & 16.2 & Average Diameter & 60.5 \\
\hline 23.96 & 20.6 & 9.69 & 11 & 23.02 & 37.8 & 43.67 & 56.5 \\
\hline Largest Diameter & 26.3 & Largest Diameter & 11.5 & Largest Diameter & 33.1 & Largest Diameter & 59.9 \\
\hline 35.2 & 23.6 & 14.7 & 10.3 & 43.2 & 35.4 & 61.5 & 56 \\
\hline Lichenometric Age & 20 & Lichenometric Age & 12 & Lichenometric Age & 39 & Lichenometric Age & 49.1 \\
\hline 78.6 & 24 & 31.6 & & 97.0 & 43.2 & 138.9 & 53.5 \\
\hline & 20.1 & & & & 38.8 & & 50.2 \\
\hline & & & & & & & 52.5 \\
\hline & & & & & & & 53.8 \\
\hline & & & & & & & 52.5 \\
\hline & & & & & & & 54.9 \\
\hline & & & & & & & 54 \\
\hline & & & & & & & 61.5 \\
\hline & & & & & & & 55 \\
\hline & & & & & & & 51.6 \\
\hline
\end{tabular}




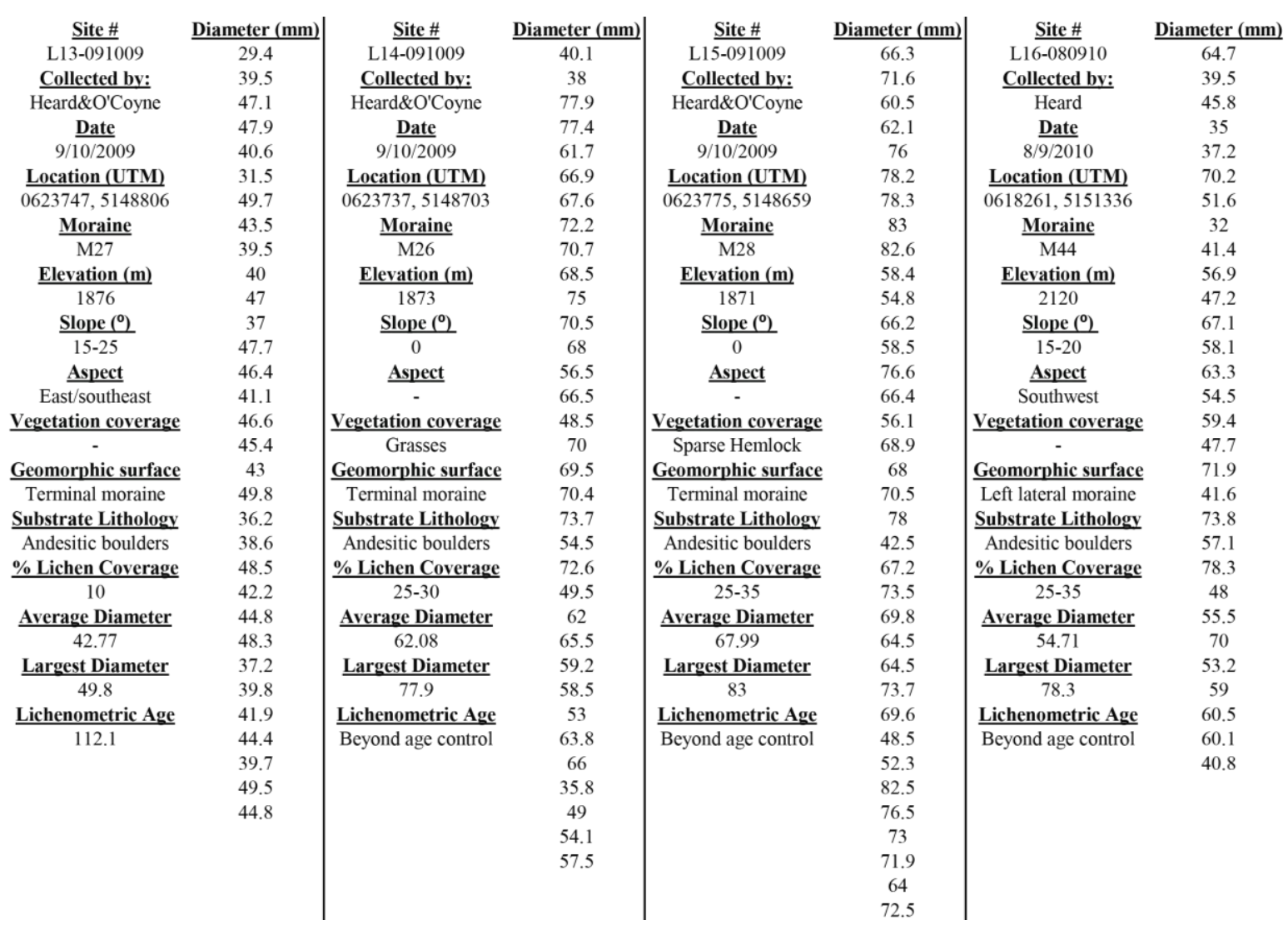




\begin{tabular}{|c|c|c|c|c|c|c|c|}
\hline$\underline{\text { Site \# }}$ & $\underline{\text { Diameter }(\mathrm{mm})}$ & Site\# & Diameter (mm) & Site \# & $\underline{\text { Diameter }(\mathrm{mm})}$ & $\underline{\text { Site \# }}$ & $\underline{\text { Diameter }(\mathrm{mm})}$ \\
\hline $\mathrm{L} 1 \overline{7-081010}$ & 20 & $\mathrm{~L} 1 \overline{8-081110}$ & 36.5 & L19-081110 & 31.3 & L20-092810 & 57.3 \\
\hline Collected bv: & 17.3 & Collected by: & 29.8 & Collected by: & 45.5 & Collected by: & 62.7 \\
\hline Heard & 17.7 & Heard\&Cockrill & 33.4 & Heard\&Cockrill & 27.5 & Heard & 65.1 \\
\hline Date & 27.5 & $\underline{\text { Date }}$ & 26.7 & Date & 27.7 & Date & 77.6 \\
\hline $8 / 10 / 2010$ & 25.2 & $8 / 11 / 2010$ & 24.2 & $8 / 11 / 2010$ & 32.4 & $9 / 28 / 2010$ & 58.5 \\
\hline Location (UTM) & 19.4 & Location (UTM) & 22.3 & Location (UTM) & 35.1 & Location (UTM) & 70.6 \\
\hline 0619741,5152071 & 20.1 & 0617649,5153774 & 31 & 0617518,5153882 & 31 & 0617546,5154011 & 49.8 \\
\hline Moraine & 21.4 & Moraine & 27.5 & Moraine & 33.5 & Moraine & 64.2 \\
\hline M7 & 23.8 & M22 & 27.7 & M23 & 29.2 & M29 & 64.7 \\
\hline Elevation (m) & 21.5 & Elevation (m) & 22.7 & Elevation (m) & 35 & Elevation (m) & 68.5 \\
\hline 2055 & 30.3 & 1635 & 26.3 & 1595 & 48 & 1589 & 70 \\
\hline Slope $\left({ }^{\circ}\right)$ & 38.1 & Slope $\left({ }^{\circ}\right)$ & 28.8 & Slope $\left({ }^{\circ}\right)$ & 29.3 & Slope $\left({ }^{\circ}\right)$ & 55.7 \\
\hline $0-5$ & 26.8 & 10 & 22.5 & 15 & 33.2 & 10 & 68.8 \\
\hline Aspect & 42 & Aspect & 26.7 & Aspect & 35.1 & Aspect & 74.1 \\
\hline Northeast & 24.5 & Northeast & 38 & Northeast & 32.9 & North,northwest & 72.4 \\
\hline Vegetation coverage & 39.9 & Vegetation coverage & 37.1 & Vegetation coverage & 35.6 & Vegetation coverage & 66.4 \\
\hline Grasses & 26 & Grasses,lupine & 24.9 & Grasses,lupine & 31.4 & Grasses & 59.7 \\
\hline Geomorphic surface & 29.5 & Geomorphic surface & 24 & Geomorphic surface & 34.5 & Geomorphic surface & 76.3 \\
\hline Right lateral moraine & 27.1 & Right lateral moraine & 32 & Right lateral moraine & 27.3 & Right lateral moraine & 72.5 \\
\hline Substrate Lithology & 22.1 & Substrate Lithology & 27.5 & Substrate Lithology & 40.5 & Substrate Lithology & 40.7 \\
\hline Andesitic boulders & 20.8 & Andesitic boulders & 34.8 & Andesitic boulders & 38 & Andesitic boulders & 66.5 \\
\hline \% Lichen Coverage & 24.8 & \% Lichen Coverage & 37.2 & \% Lichen Coverage & 31.2 & \% Lichen Coverage & 45.2 \\
\hline 10 & 19 & 10 & 21.5 & $<20$ & 26.9 & $<50$ & 64.9 \\
\hline Average Diameter & 22.5 & Average Diameter & 27 & Average Diameter & 48.6 & Average Diameter & 68.3 \\
\hline 27.62 & 29.6 & 30.94 & 40.4 & 35.06 & 46.9 & 63.95 & 61.1 \\
\hline Largest Diameter & 32.1 & Largest Diameter & 47.6 & Largest Diameter & 33 & Largest Diameter & 70.8 \\
\hline 42 & 36.5 & 48.8 & 48.8 & 54 & 42.1 & 77.6 & 71.2 \\
\hline Lichenometric Age & 34.2 & Lichenometric Age & 39.4 & Lichenometric Age & 26 & Lichenometric Age & 67.4 \\
\hline 94.2 & 32.8 & 109.8 & & 121.7 & 39.9 & $\overline{\text { Beyond age control }}$ & 46.2 \\
\hline & 37.7 & & & & 54 & & 68.2 \\
\hline & 30.8 & & & & 28.7 & & 57 \\
\hline & 35.5 & & & & 31.5 & & \\
\hline & 29 & & & & 33.8 & & \\
\hline & 27.6 & & & & 33 & & \\
\hline & 33.6 & & & & 36.5 & & \\
\hline & & & & & 36.2 & & \\
\hline
\end{tabular}




\section{Appendix D: Volcanic ash deposit results}

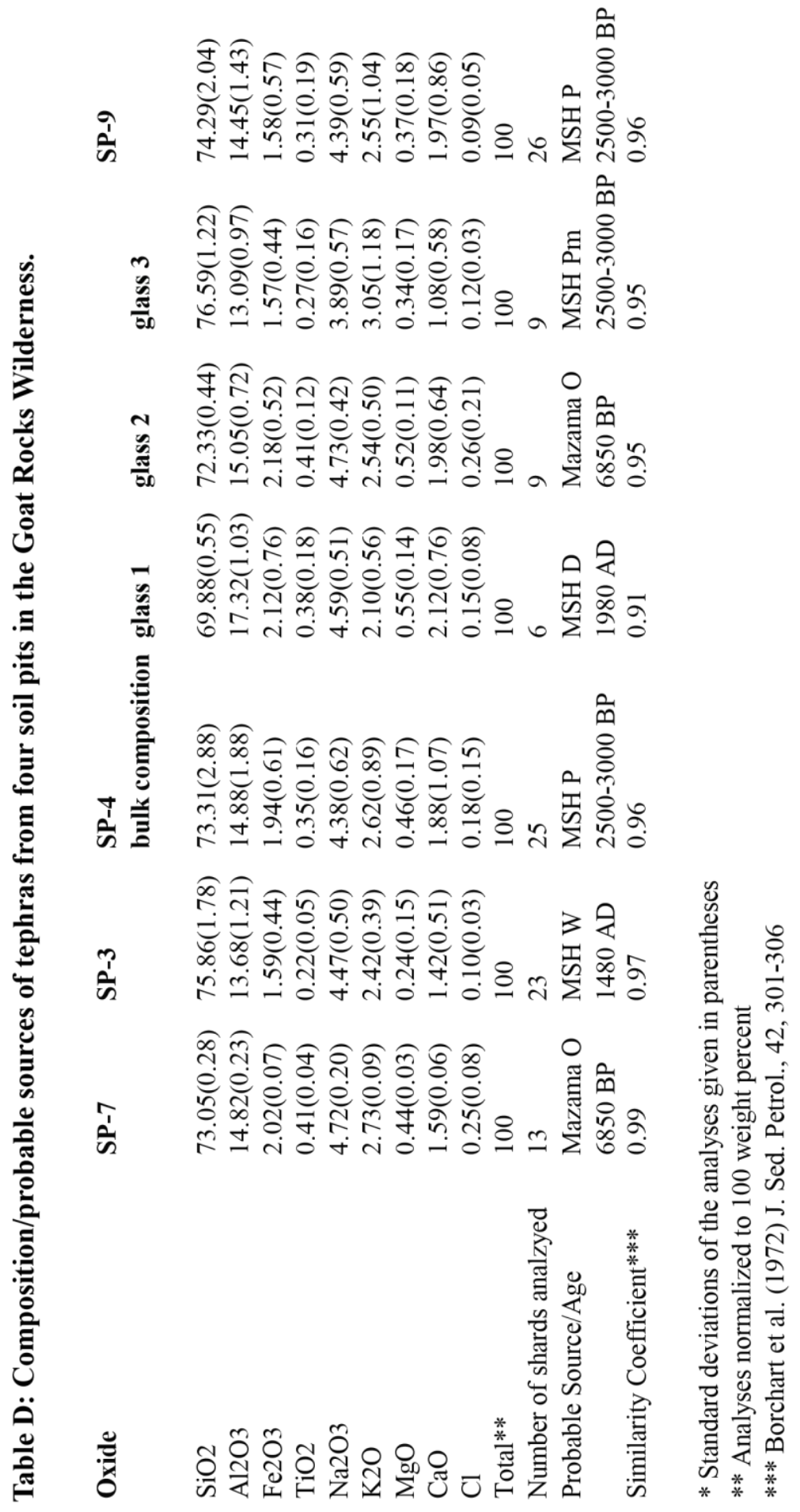

